UNIVERSIDADE DE SÃO PAULO

FACULDADE DE FILOSOFIA, LETRAS E CIÊNCIAS HUMANAS DEPARTAMENTO DE LETRAS MODERNAS

PROGRAMA DE PÓS-GRADUAÇÃO EM LÍNGUA ESPANHOLA E LITERATURA ESPANHOLA E HISPANO-AMERICANA

VÂNIA PILAR CHACON ESPINDOLA

A NOVELA EXEMPLAR "EL COLOQUIO DE LOS PERROS" E OS PRECEITOS DO GÊNERO CÔMICO

Versão Corrigida

SÃO PAULO

2015 
UNIVERSIDADE DE SÃO PAULO

FACULDADE DE FILOSOFIA, LETRAS E CIÊNCIAS HUMANAS DEPARTAMENTO DE LETRAS MODERNAS

PROGRAMA DE PÓS-GRADUAÇÃO EM LÍNGUA ESPANHOLA E LITERATURA ESPANHOLA E HISPANO-AMERICANA

\title{
A NOVELA EXEMPLAR "EL COLOQUIO DE LOS PERROS" E OS PRECEITOS DO GÊNERO CÔMICO
}

\author{
Vânia Pilar Chacon Espindola
}

Dissertação apresentada ao Programa de Pós-Graduação em Língua Espanhola e Literatura Espanhola e HispanoAmericana do Departamento de Letras Modernas da Faculdade de Filosofia, Letras e Ciências Humanas da Universidade de São Paulo, para a obtenção do título de Mestre em Letras.

Orientadora: $\operatorname{Prof}^{\mathrm{a}}$ Dra. Maria Augusta da Costa Vieira

Versão Corrigida

SÃO PAULO 


\section{FOLHA DE APROVAÇÃO}

Vânia Pilar Chacon Espindola

A novela exemplar: El coloquio de los perros e os preceitos do gênero cômico.

Dissertação apresentada ao Programa de PósGraduação em Língua Espanhola e Literatura Espanhola e Hispano-Americana do Departamento de Letras Modernas da Faculdade de Filosofia, Letras e Ciências Humanas da Universidade de São Paulo, para a obtenção do título de Mestre em Letras.

Data de Aprovação

\section{Banca Examinadora}

Prof. Dr.

Instituição:

Assinatura:

Prof. Dr.

Instituição:

Assinatura:

Prof. Dr.

Instituição:

Assinatura: 
Para Luiz Antonio Espindola 


\section{AGRADECIMENTOS}

Em primeiro lugar agradeço a Prof ${ }^{a}$. Dra. Maria Augusta da Costa Vieira, minha orientadora, pela oportunidade, carinho e dedicação dispensados para com esta pesquisa e, de maneira especial, por me conduzir pelos caminhos interpretativos da escrita cervantina.

Agradeço também ao Prof. Dr. João Adolfo Hansen e à Profa. Dra. Lucia.Wataghin pelas valiosas sugestões feitas na ocasião de meu exame de qualificação.

Em seguida, gostaria de agradecer os Professores Dr. João Adolfo Hansen, Prof ${ }^{a}$. Dra. Maria Augusta da Costa Vieira e Prof. Dr. José Manuel Lucía Megías, Prof ${ }^{a}$ Dra. Adma Fadul Muhana e Prof ${ }^{a}$ Dra. Maria do Socorro Fernandes de Carvalho ministrantes das disciplinas de Pós-Graduação que colaboraram para o enriquecimento desse trabalho dissertativo.

À estimada Silvia Massimini pela leitura atenta e revisão dessa pesquisa.

Com muito carinho agradeço a minha querida companheira de jornada Ana Aparecida Teixeira da Cruz pela amizade e apoio.

À Eleni Nogueira dos Santos pela ajuda por ocasião do Exame de Qualificação e à Marta Pérez Rodríguez por ter me conduzido ao Grupo de estudos cervantinos.

A todos os colegas do Grupo de estudos cervantinos pelas inúmeras discussões bastante frutíferas sobre Cervantes e os estudos críticos de sua obra.

Agradeço ao meu marido Luiz Antonio Espindola pelo incentivo e por estar em minha vida.

Aos meus filhos: Luiz Fernando Espindola, Patrícia Espindola e Luiz Eduardo Espindola - minhas três maiores realizações.

Aos meus pais Emir Chacon Perez, (in memoriam) e Aparecida Parra Chacon.

Enfim, agradeço a minha querida avó e mãe de coração Josefa Perez Chacon (in memoriam) por despertar em mim o amor pela Espanha, por sua cultura e costumes. 


\section{RESUMO}

ESPINDOLA, Vânia Pilar Chacon. A novela exemplar "El coloquio de los perros" e os preceitos do gênero cômico. 2014, 234f. Dissertação (Mestrado) - Faculdade de Filosofia, Letras e Ciências Humanas, Universidade de São Paulo, São Paulo, 2014.

Este trabalho tem o objetivo de estudar alguns aspectos do gênero cômico na novela exemplar El coloquio de los perros de Miguel de Cervantes. Com este propósito, foram escolhidos os quatro primeiros episódios da obra: o matadouro de Sevilha, Berganza como cão pastor, o rico comerciante e o oficial de justiça, tendo como ponto de partida o estudo analítico da comicidade, levando em conta a maneira como se constitui no corpus selecionado, seja por intermédio do elemento burlesco, seja pelo satírico, com a perspectiva de promover o entretenimento, o riso. Para realizar tal análise observou-se como essas formas discursivas se constituem no interior da narrativa/diálogo, destacando o que as distingue em cada episódio selecionado, a fim de desvendar de que maneira esse diálogo cômico-filosófico nos remete a uma censura sócio-moral, um dos temas centrais dessa obra de Cervantes.

Palavras-chave: Cervantes, "Coloquio de los perros”, cômico, censura, riso. 


\begin{abstract}
ESPINDOLA, Vânia Pilar Chacon, The exemplary novel: El coloquio de los perros and the precepts of the comic genre. 2014, 234f. Dissertation (Master's degree) Faculdade de Filosofia, Letras e Ciências Humanas, Universidade de São Paulo, São Paulo, 2014.

This work aims to study some aspects of the comic genre in the exemplary novel $E l$ coloquio de los perros by Miguel de Cervantes. For this purpose the first four episodes of the work were selected: Slaughterhouse of Seville, Berganza as shepherd dog, the wealthy merchant and the bailiff. The chosen starting point was the analytical study of the comicality, taking into account the way it is constituted in the selected corpus, either through the burlesque element, or by the satirical one, with the perspective to promote entertainment, laughter. For such analysis, it was observed how these discursive forms are constituted within this narrative/dialogue, highlighting what distinguishes each one in the selected episodes, in order to unravel how this comical-philosophical dialogue leads us to a socio-moral censure, one of the central themes of this work of Cervantes.
\end{abstract}

Keywords: Cervantes, El coloquio de los perros. Comical, Censorship, Laughter. 


\section{RESUMEN}

ESPINDOLA, Vânia Pilar Chacon, La novela ejemplar: El coloquio de los perros y los preceptos del género cómico. 2014, 234f. Tesina (Maestría) - Faculdade de Filosofia, Letras e Ciências Humanas, Universidade de São Paulo, São Paulo, 2014.

El objetivo de este trabajo está en estudiar algunos aspectos del género cómico en la novela ejemplar El coloquio de los perros de Miguel de Cervantes. Con este propósito, se eligieron los cuatro primeros episodios de la obra: el matadero de Sevilla, Berganza como perro pastor, el mercader rico y el alguacil, tomando como punto de partida el estudio analítico de la comicidad, teniendo en cuenta la forma en que se encuentra en el corpus seleccionado, ya sea por medio del elemento burlesco o a través del satírico, con la perspectiva de promover el entretenimiento y la risa. Para realizar tal análisis, se observó que estas formas discursivas se constituyen dentro de la narración / diálogo, destacando lo que las distingue en cada episodio escogido, con el fin de desvelar cómo este diálogo cómico-filosófico nos lleva a una censura socio-moral, uno de los temas centrales de esta obra de Cervantes.

Palabras claves: Cervantes, coloquio, cómico, el burlador burlado 
Todo cuanto diga un orador de buena conducta, ha de ser sin faltar a la dignidad, y decoro, ni a la vergüenza.

Quintiliano 


\section{SUMÁRIO}

Introdução 1

I. O DOM ADMIRÁVEL E OUTROS SUCESSOS DA VIDA DE

BERGANZA

1. Conciliar o admirável com a verossimilhança......................................................13

2. O episódio do Matadouro: uma narrativa engenhosa ….........................................28

3. A relação mestre e discípulo - o riso através das censuras de Cipión

II. A VIDA NO CAMPO - BERGANZA, O CÃO PASTOR

1. A aparente pureza do campo, as lembranças da cidade 60

2. O riso a serviço da sátira, da prédica e da murmuração .73

3. O gênero pastoril como modelo questionável - um mundo às avessas 88

III. BERGANZA, O RICO COMERCIANTE E OUTROS ACONTECIMENTOS

1. Berganza e as relações amo e criado 103

2. Berganza, a Companhia de Jesus e os reveses da fortuna. 117

3. A pretensa filosofia de Berganza e sua relação com os escravos da casa.

IV. "EL FAMOSO PERRO DE AYUDA" E O OFICIAL DE JUSTIÇA

1. Berganza, um possível ator de entremez. 148

2. Outras artimanhas do oficial de justiça - "creció la fama de mi cobarde". 166

3. O oficial de justiça - "el burlador burlado" 180

Considerações finais. 193

Referências bibliográficas. 199 


\section{Introdução}

Si el hombre de las cavernas hubiera sabido reír, la historia sería otra.

Eugène Ionesco

Como se sabe, o riso é um traço exclusivamente humano e suas manifestações e representações variam de acordo com as diversas culturas existentes. Já se observou que indivíduos de um mesmo grupo não o percebem da mesma forma, o que se dirá de grupos distintos, de outras culturas e crenças, com pensamentos e sentimentos diversos.

Assim, o riso surge como manifestação/representação ora por meio da brincadeira pueril, ora mediante uma censura irônica e mordaz; o certo é que não há uma teoria definitiva a respeito do riso, em função de existirem diversos pontos de vista sobre o tema, o que causa, em muitos campos de investigação, certa falta de critérios e teorias comuns, levando-se em conta a complexidade do assunto (LE GOFF, 1997, p. 65-8).

Para Le Goff, o riso é um fenômeno cultural e está vinculado a práticas sociais, ou seja, de que maneira ele se apresenta, seus temas, seus alvos; o riso possui códigos e rituais próprios, sempre presente no palco da vida e das relações humanas. Entretanto, sua atuação não é constante, não se inspira nas mesmas situações, seu foco sofre mutações: pois, como um personagem, ele se integra nas condutas sociais, adequandose a várias situações, sejam elas culturais, políticas ou econômicas, sejam relacionadas a questões comportamentais ou religiosas.

Ao se pensar na Idade Média, por exemplo, todas as ações e doutrinas eram baseadas em modelos provenientes dos textos sagrados da Bíblia, como forma de orientação e exemplo a ser seguidos, especialmente pelos membros do clero. Acredita- 
se que até o século XIV todos os preceitos tinham como ponto de partida os textos do Velho e Novo Testamentos. É oportuno lembrar que um dos personagens mais relevantes do Velho Testamento é Isaac, que significa "riso" (LE GOFF, 1997, p. 76). Segundo o historiador, no Antigo Testamento já se estabelecia uma distinção com respeito às duas formas de riso marcadas por palavras em hebraico, que eram diferenciadas, respectivamente: "sakhaq", riso feliz; e "iaag", riso que denigre.

Nesse sentido, ao analisar o riso na Antiguidade, Javier Martin Camacho salienta que esses dois tipos de riso apontados na Bíblia demonstram dois aspectos fundamentais que as tradições hebreia e grega mantiveram em suas doutrinas, isto é, a existência de um riso relacionado à alegria e ao prazer, e outro mordaz (MARTIN CAMACHO, 2011, p. 4).

Observa-se tais questões no episódio bíblico que anuncia o nascimento de um filho para Abraão e Sara, conforme o fragmento a seguir:

E Sara escutava à porta da tenda, que estava atrás dele.

E eram Abraão e Sara já velhos, e adiantados em idade; já a Sara havia cessado o costume das mulheres.

Assim, pois, riu-se Sara consigo, dizendo: Terei ainda deleite depois de haver envelhecido, sendo também o meu senhor já velho?

E disse o Senhor a Abraão: Por que se riu Sara, dizendo: Na verdade darei eu à luz ainda, havendo já envelhecido?

Haveria coisa alguma difícil ao Senhor? Ao tempo determinado tornarei a ti por este tempo da vida, e Sara terá um filho.

E Sara negou, dizendo: Não me ri; porquanto temeu. E ele disse: Não digas isso, porque te riste. (Gn 18,10-15)

Por intermédio desse riso, Sara manifesta certa incredulidade, até mesmo porque ela e Abraão já contavam com uma idade avançada. Ao perceber seu riso, o Senhor a questiona; Sara tenta negar a ação em sinal de temor, mas Deus insiste em desmenti-la, afinal ela rira. Esse riso para Camacho revela o lado íntimo do ser, e é por essa razão 
que em muitas culturas as mulheres tapam a boca ao rirem, demonstrando que em todos os tempos, de alguma forma, a representação do riso foi coibida, limitada ou instruída. (MARTIN CAMACHO, 2011, p. 4).

É importante lembrar que esse riso contido ou limitado a certas convenções sociais foi mencionado na obra de Cícero (106-43 a.C.). Seu último tratado, Sobre los deveres, texto destinado a servir de orientação tanto ao seu filho Marco quanto aos jovens romanos, contém uma série de procedimentos morais e éticos, destinados a direcionar as ações dos indivíduos, seus valores e deveres para com a sociedade e para com a pátria. Em um trecho desse tratado, o senador romano faz alusão ao uso da graça no convívio social, porém de maneira fina e educada. Até mesmo porque, para Cícero, há dois tipos de graça: uma insolente, torpe e desonesta, outra elegante, com engenho, graciosa. Esta, utilizada em momentos de descontração da alma, é inerente a homens mais austeros, própria da urbanitas; a outra surge quando a indecência do argumento se une a palavras obscenas, scurrilitas. (CICERÓN, 2008, pp. 110-2). Assim, para Cícero o riso deve conter certa medida, evitando-se os excessos para que estes não conduzam a algum tipo de obscenidade. Esses princípios reforçam os já existentes em seu tratado $D e$ Oratore, no qual o senador reúne grande número de exemplos para ilustrar e fundamentar suas afirmações. Neste livro, Cícero já orientava os oradores de seu tempo sobre a importância do riso como forma de cativar a benevolência dos ouvintes e advertia que existiam regras para se suscitar esse riso, pois o riso é uma arte e deve ser tratado como tal, seguindo os limites do respeito e da prudência para ser aceito socialmente. (CICERÓN, 1951, pp. 141-3).

No recente artigo de Fritz Graf sobre o riso da Roma antiga, o pesquisador ressalta que havia dois gêneros dedicados ao risível naqueles tempos: a comédia, com seu riso polido, inventivo, engraçado; e a sátira, com sua manifestação inaceitável, percebida em escravos ou em homens de má reputação e que apresentava um estilo 
petulante, infame e obsceno (GRAF, 1997, pp. 51-64). Graf, ao rever as opiniões de Quintiliano (35-100 d.C.) a respeito de todas as doutrinas e exemplos deixados por Cícero em suas obras, acrescenta que o senador foi censurado em seu tempo por exercer "a boa medida da graça" em seus discursos, chegando a ser apelidado por alguns de seus contemporâneos de scurra (palhaço) (GRAF, 1997, p. 52).

É curioso observar que o riso surge sempre de uma ocorrência inesperada, de uma quebra de expectativas, pois se manifesta através da incongruência que põe em evidência toda uma vulnerabilidade do homem; se, em um instante, o indivíduo provoca o riso, em outro é alvo desse mesmo riso. Embora não exista uma teoria absoluta que o defina, o riso sempre apresentou conceitos que o descrevem como uma forma de expressão que se apresenta de duas maneiras, isto é, se por um lado ele é gracioso e benevolente, por outro ele é mordaz, nocivo. Essas características foram apontadas por Aristóteles em seu tempo, pois para ele o riso deve ser comedido e não vulgar, até mesmo porque a comédia é imitação dos piores indivíduos, não por terem todo tipo de defeito, mas um em particular: o ridículo que está relacionado ao feio. (ARISTÓTELES, 2009, p. 45)

Essa doutrina aristotélica foi desenvolvida por Cícero, e nos séculos XVI e XVII culminou em diversos tratados relacionados ao tema. Um desses tratados é Philosophía antigua poética, publicado em 1596 em Madri, de autoria de Alonso López Pinciano. Como se sabe, El Pinciano, como era conhecido, foi considerado um dos mais eminentes humanistas espanhóis desse período, conseguindo um espaço privilegiado entre os preceptistas por intermédio dessa poética. Nessa obra, o autor cria um tratado pedagógico (PINCIANO, 1973, p. xv) a respeito da matéria poética, baseando-se para tal fim na teoria aristotélica, bem como na horaciana. Assim, para Pinciano a comédia é imitação do pior dos piores, ela consegue despertar o riso com passatempos e entretenimentos, ensinando com isso a prudência para o governo do homem de família. 
Dessa maneira a comédia, segundo o preceptista, é fábula que manifesta o útil e o nocivo para a vida humana - uma produção popular que diverte.

Essa característica marcou muitas obras do século XVII, cujos preceitos serviram de modelo a diversos autores do chamado Siglo de Oro das belas-letras na Espanha. Assim, entre o período de 1590 a 1612 Miguel de Cervantes concebe um conjunto de doze novelas com o título Novelas ejemplares, publicado em 1613 na cidade de Madri, após ter editado a primeira parte de Dom Quixote.

No entanto, o que se pode entender por novelas exemplares? O termo exemplar sugere alguma característica que as individualiza?

Para responder a essas questões, proponho observarmos atentamente o que Cervantes menciona no Prólogo das Exemplares ${ }^{1}$ : "Heles dado nombre de ejemplares, y si bien lo miras, no hay ninguna de quien no se pueda sacar algún ejemplo provechoso [...]" (CERVANTES, 2005, pp. 79-80).

Conforme declarado pelo próprio autor, dessas novelas pode-se tirar sempre um bom exemplo, muito embora retratem um aprofundamento, por parte de Cervantes, de formas novelescas que as precedem, dentro e fora da Espanha, como é o caso da obra anônima Lazarillo de Tormes e as novellas italianas, cujos possíveis modelos são sobretudo Boccaccio e Bandello. Conforme Rey Hazas e Sevilla Arroyo, não há como esquecer as variações que se seguiram a partir da tradição italiana, de continuadores franceses com a tradução das Histoires tragiques de Bandello, com o que se aprofundou a nouvelle francesa. ${ }^{2}$ Além disso, há que se considerar a novela picaresca, a pastoril, as novelas de cavalaria, fábulas, diálogos e anedotas, cujos modelos provavelmente conduziram à composição das Novelas ejemplares (p. 21-2).

\footnotetext{
${ }^{1}$ CERVANTES, Miguel de. "El coloquio de los perros". In: Novelas ejemplares. Barcelona: Crítica, 2005. Todas as citações de "El coloquio de los perros" serão referentes a esta edição; a partir de agora, ndicaremos apenas os números das páginas entre parênteses.

${ }^{2}$ CERVANTES, Miguel de. "El coloquio de los perros". In: Novelas ejemplares. Madrid: Austral, 2011. p. 21.
} 
Nesses termos, para o leitor coetâneo de Cervantes, o adjetivo "exemplar" significava não somente que a novela continha um ensinamento moral, como também se ajustava a uma construção moralizadora ${ }^{3}$. Entretanto, para Rey Hazas y Sevilla Arroyo, nenhuma narração cervantina se ajusta a tal construção nem serve de exemplo ilustrativo ou sentença alguma. Ao citarem E. Riley, os pesquisadores concordam que Cervantes entendia a exemplaridade como representação da vida, interessado em inovar o significado do termo. Conforme estudiosos, o autor de Dom Quixote advertia o leitor para que percebesse que "[...] la obra bien hecha, verosímil y coherente, la que origina el goce intelectual que la verdad artística y literaria produce, conlleva inevitablemente unida la satisfacción moral” (p. 29).

Acrescenta-se, ainda, que Cervantes sentia necessidade de elevar o conceito do gênero novelesco, que tinha fama de imoral e sem pudor, adquirida pela herança de Boccaccio com seu Decameron. Por isso, o leitor do século XVII, provavelmente, ao ler o título Novelas ejemplares, se deparava com algo que poderia ser surpreendente, devido ao fato de a junção dos termos ser contraditória. Nesse aspecto, de acordo com Rey Hazas e Sevilla Arroyo, Cervantes tinha o propósito de dignificar o gênero, apresentando questões exemplares e éticas direcionadas ao entretenimento, pois segundo preceitos horacianos não se concebia o ensinamento sem o deleite. Portanto, percebe-se que não existe uma moral expressa, conforme advertência do autor mediante a frase: "si bien lo miras", a fim de que seu leitor não se equivoque.

Com relação à pergunta inicial a respeito de existir algo que as individualize, acredita-se que o próprio Cervantes tenha respondido a essa questão quando afirma: "[...] quizá te mostrara el sabroso y honesto fruto que se podría sacar, así de todas

\footnotetext{
${ }^{3}$ REY HAZAS, Antonio; SEVILLA ARROYO, Florencio. "Introducción a las Novelas ejemplares". In: CERVANTES, Miguel de. Novelas ejemplares, la nueva concepción de la ejemplaridad e la poética de la libertad. Madrid: Austral, 2011. p. 27-31.
} 
juntas como de cada una de por sí” (pp. 79-80), ou seja, que dessas novelas pode-se extrair um exemplo proveitoso seja de todas juntas ou de cada uma delas.

Perseguindo essa exemplaridade que, segundo Riley, pode ser encontrada na junção da verdade poética com a moral, nos deparamos com a última novela exemplar, "El coloquio de los perros", que tem seu início, na realidade, no final da penúltima das novelas, "El casamiento engañoso", no momento em que seu protagonista, o alferes Campuzano, encontrava-se no Hospital da Ressurreição de Valladolid acometido de um ataque de sífilis, fruto de seu falso casamento com Estefanía. Em uma noite de delírio, o alferes flagra um diálogo entre os dois cães de guarda do hospital, cuja matéria decide transcrever ipsis litteris, surgindo dessa forma "El coloquio de los perros" ou "Novela y coloquio que pasó entre Cipión y Berganza”.

Campuzano, após sair do hospital, encontra-se com seu amigo, o licenciado Peralta. Este o leva para sua pousada e toma conhecimento do incrível evento. Mesmo com muita incredulidade, Peralta se dispõe a ler o relato e, assim, a novela "El coloquio de los perros" se converte em uma narrativa surpreendente, no instante em que seus protagonistas, Berganza ${ }^{4}$ e Cipión ${ }^{5}$, se veem de posse do dom da fala. Por esse motivo, decidem aproveitar essa dádiva narrando a história de suas vidas, a começar pela história de Berganza; os dois têm a esperança de que esse dom se estenda e Cipión possa narrar sua vida, sucessos e desventuras.

\footnotetext{
${ }^{4} \mathrm{O}$ nome Berganza foi relacionado tanto com Cervantes (narrador) quanto com bergante (salteador e, em castelhano da época, picarón, sinvergüenza e de malas costumbres); Cipión: Cipión > Scipión (o crítico). Extraído da edição: CERVANTES, Miguel de. "El coloquio de los perros". In: Novelas Ejemplares. Barcelona: Crítica, 2005.

${ }^{5}$ Cipión: Pode-se relacionar a discrição e a prudência de Cipión com as características de Cipião Emiliano, personagem do relato de Marco T. Cícero em sua obra De Re Publica composta em 54-51 a.C. O senador narra que Cipião Emiliano encontra-se com o rei Massinissa, amigo da família, e este chora ao recordar os feitos de seu avô, Cipião, o Africano. Durante a noite, Cipião Emiliano sonha com o avô que o aconselha a percorrer o caminho da virtude e da honra, sem valorizar a fama: "Ten valor y rechaza el miedo, oh Scipio; [...] cultiva la justicia y la piedad".

Disponível em: http://smejuto.blogspot.com/2010/01/el-sueno-de-escipion-marco-tulio.html. Acesso em: 7 out. 2013.
} 
Berganza inicia esse relato de vida partindo de seu nascimento no Matadouro de Sevilha e nos fala sobre seu primeiro amo, Nicolás el Romo, um açougueiro, robusto e colérico. No entanto, após inúmeras peripécias e desventuras, Berganza foge, dando início a uma sequência de amos e lugares relacionados, os quais irão compor todo esse diálogo estabelecido pelos cães.

Diante dessa obra tão singular, surgiu o interesse em estudá-la com o intuito de analisar o gênero cômico, seja por intermédio do elemento burlesco, seja pela presença do satírico, e a maneira como essas formas discursivas se constituem no interior da novela, partindo do pressuposto de que a obra transita entre ambas, a serviço de uma censura moral manifesta.

É oportuno ressaltar que a escolha dessa novela exemplar se deve ao seu caráter plural, pois sua temática aborda diversas questões, ora sociais, ora filosóficas, a fim de introduzir uma censura direcionada ao comportamento de personagens tipo, diante de situações do próprio cotidiano.

Cabe esclarecer que esta dissertação teve como escopo apenas o estudo e a análise das formas discursivas mencionadas, no que diz respeito aos quatro primeiros episódios da novela exemplar "El coloquio de los perros". Essa explicação deve-se ao fato de o "Coloquio" principiar no final da novela anterior, "El casamiento engañoso".

Dessa forma, considerando o ponto fulcral dessa pesquisa, compete discorrer sobre os procedimentos metodológicos empregados na composição desses estudos, no que tange ao referencial teórico selecionado. No que se refere à novela "El coloquio de los perros", buscou-se o caráter técnico e cultural dos textos do período compreendido entre os séculos XVI e XVII. Igualmente, fez-se necessária a leitura do tratado de poética de Aristóteles, bem como de preceptistas e estudiosos antigos e modernos, cujas escrituras tiveram como objetivo os temas propostos. 
Nesse contexto, o primeiro capítulo da presente dissertação, intitulado “O dom admirável e outros sucessos da vida de Berganza", teve como ponto de partida o estudo analítico dos conceitos de verossimilhança, admiratio e maravilha, devido à abordagem desses princípios feita pelos protagonistas caninos.

Assim, coube retomar os estudos do tratadista seiscentista Alonso López Pinciano, em sua Philosophía antigua poética, a respeito da verossimilhança, bem como seu parecer com respeito às fábulas esópicas, uma vez que muitas delas continham animais que dialogavam com racionalidade, aos moldes da novela exemplar "El coloquio de los perros".

Paralelamente, foi de suma importância rever os estudos de Vincenzo Maggi (1498-1564) e seu tratado de 1550 , De ridiculis, pois o tema se refere à reação de comicidade que toda a admiração desperta.

Além disso, em função de a novela se pautar por um diálogo estabelecido entre dois cães com conhecimento filosófico, se fez necessária uma reflexão sobre algumas obras que referendaram o tema, como é o caso de El asno de oro de Apuleio, Murmuraban los rocines (1593) de Góngora, Diálogo entre dos perrillos de Baltasar del Alcázar, sendo que as duas últimas obras compõem exemplos de diálogos entre animais na poesia satírico-burlesca dos séculos XVI e XVII. Por fim, coube analisar, da obra cervantina, Diálogo de Babieca y Rocinante, nos preliminares da primeira parte de $E l$ ingenioso hidalgo Don Quijote de la Mancha.

Essas leituras caminharam na direção dos estudos contemporâneos feitos por Edward C. Riley, Eduardo Urbina, Fernando Rodríguez Mansilla, Antonio Armisen, e Rogelio Miñana, os quais trataram dos conceitos de admiratio e verossimilhança na obra cervantina, bem como de autores pertencentes às belas-letras dos séculos XVI e XVII. 
Na sequência, Berganza inicia a história de sua vida, a partir de seu nascimento no Matadouro de Sevilha. Nessa passagem da novela, o cão irá tecer uma censura moral, utilizando-se de figuras/imagens, analogias e metáforas, com a finalidade de estabelecer um colóquio agudo que prima pelo engenho, com o possível propósito de promover o riso.

Para o desenvolvimento do tema acima exposto, a metodologia utilizada teve como ponto de partida a retomada de preceitos antigos por intermédio do tratado de Alonso López Pinciano. Além disso, por compreender que a agudeza, no século XVII, era fruto de uma mente engenhosa, iluminada pela Graça Divina, coube rever os estudos quinhentistas de Juan Huarte de San Juan. Nessa linha, ainda, a análise deste capítulo contou com os trabalhos de autores modernos, tais como Edward C. Riley, Antony Close, Maria Augusta da Costa Vieira e João Adolfo Hansen, entre outros. Em síntese, espera-se demonstrar, por meio dessa abordagem, a confluência existente entre o texto cervantino e determinados aspectos mencionados por essas pesquisas tanto no que concerne ao caráter técnico das produções do século XVII quanto aos elementos pertencentes ao gênero cômico e suas representações.

O segundo capítulo dedicou-se à investigação da aproximação do gênero pastoril com algumas produções escritas dos séculos XVI e XVII. Nesse episódio foram abordados alguns temas tais como: a relação antitética campo-cidade, bem como a aparente superficialidade do gênero arcádico em comparação com a vida dos pastores amos de Berganza. A metodologia aplicada na análise desse capítulo contou com os textos de autores como Antonio de Guevara, Juan Luis Vives, Antonio de Torquemada e Fray Luis de León, propondo também os estudos modernos feitos por Juan Bautista Avalle-Arce, Gustavo Illades e Antonio Ríos Rojas, por suas análises a respeito do gênero pastoril, bem como o tema que se refere à antítese campo-cidade. 
Ademais, diante da observância do termo "murmuración", constantemente utilizado pelos protagonistas, coube consultar os estudos atuais feitos por Gustavo Illades em seu artigo "Sátira, prédica y murmuración: genealogía de una contienda por la voz en el Quijote de 1605", bem como trabalhos que caminham no mesmo terreno interpretativo.

Diferentemente dos anteriores, o terceiro capítulo inicia-se com uma apologia à humildade, "la humildad es la basa y fundamento de todas virtudes" (Cervantes, 2005, p. 666), ou seja, esse episódio se dedica a diversos temas sociais e religiosos, a relação amo e criado e a observância da aplicação dos códigos de conduta na sociedade cortesã.

Nessa esteira, fez-se necessário o estudo dos tratados de civilidade, espelhos de príncipes, cujos discursos se caracterizam por seu caráter político-moral. Como referência à temática proposta, foram estudadas as obras: A civilidade pueril e Educación del príncipe cristiano de Erasmo de Rotterdam, Tratado de la enseñanza, Introducción a la sabiduría, Escolta del alma, Diálogos y pedagogía pueril de Juan Luis Vives, Idea de un príncipe político cristiano de Diego Saavedra Fajardo, e o estudo atual de João Adolfo Hansen intitulado: Educando príncipes no espelho, sem contar os textos que foram incluídos ao longo das análises, levando em conta a similitude dos temas tratados.

Nessa configuração, para que se pudesse analisar a maneira com que Cervantes articula essa temática no interior da novela, tendo em vista a autoridade exercida por esses tratados de civilidade na formação do homem discreto, foi imprescindível recorrer ao estudo de autores como Baldassare Castiglione, Baltasar Gracián, da obra Da dissimulação honesta de Torquato Accetto, entre outros, bem como aos trabalhos contemporâneos relacionados aos temas indicados feitos pelos pesquisadores Maria Augusta da Costa Vieira e João Adolfo Hansen. 
Por fim, o quarto capítulo trata da convivência de Berganza com outro amo, um oficial de justiça corrupto. Por intermédio das peripécias apresentadas neste episódio da novela, coube um estudo dedicado ao entremez. Esse episódio do "Coloquio" foi muito significativo, pois além de sintetizar várias das questões encontradas nos episódios anteriores, abriu a possibilidade de se tecer algumas considerações relacionadas ao tema central desta dissertação, isto é, o estudo do gênero cômico no interior da estrutura dialogal da novela exemplar "El coloquio de los perros". O distinto emprego de tais procedimentos foi responsável por conduzir a questões que abordaram problemas sociais com extensões morais, contidas nesse incrível diálogo canino. 
I. O DOM ADMIRÁVEL E OUTROS SUCESSOS DA VIDA DE BERGANZA 


\section{Conciliar o admirável com a verossimilhança}

BERGANZA. Todo lo que dices, Cipión, entiendo, y el decirlo tú y entenderlo yo me causa nueva admiración y nueva maravilla. ${ }^{6}$

"El coloquio de los perros", Miguel de Cervantes

Em um leito no Hospital da Ressurreição, na cidade de Valladolid, o alferes Campuzano segue sofrendo de um ataque de sífilis. Em sua penúltima noite de febre e suores, ele flagra um fantástico acontecimento, conforme o fragmento a seguir:

CAMPUZANO. “[...] echados detrás de mi cama en unas esteras viejas, y, a la mitad de aquella noche, estando a escuras y desvelado, $[\ldots]$ oí hablar allí junto $[\ldots]$ los que hablaban, y eran los dos perros Cipión y Berganza. (CERVANTES, 2005, p. 644)

Com muita incredulidade, Campuzano escuta o diálogo que se dá entre os dois cães de guarda do hospital, muito embora não conseguisse dar crédito ao seu próprio entendimento, parecia um sonho. Mas, estando acordado, "con todos mis cinco sentidos, tales cuales Nuestro Señor fue servido dármelos, oí, escuché, noté.” (p. 645). Até mesmo porque as coisas que eram tratadas pelos dois cães, na opinião do alferes, “[ ...] fueron grandes y diferentes, y más para ser tratadas por varones sabios que para ser dichas por bocas de perros.” (p. 645).

E, como se achava em perfeito juízo, tendo "desocupada la memoria", Campuzano decide transcrever o diálogo com as mesmas palavras que o ouviu, sem

\footnotetext{
${ }^{6}$ CERVANTES, Miguel de. "El coloquio de los perros". In: Novelas ejemplares. Barcelona: Crítica, 2005.
} 
"buscar colores retóricas para adornalo, ni qué añadir ni quitar para hacerle gustoso" (p. 646).

Dessa maneira, a novela exemplar "El coloquio de los perros" tem seu início no instante em que Cipión e Berganza se veem de posse do dom da fala. Ansiosos por fazerem uso dessa inesperada dádiva, os dois iniciam o diálogo que se segue:

CIPIÓN. Berganza amigo, dejemos esta noche el hospital en guarda de la confianza y retirémonos a esta soledad y entre estas esteras, donde podremos gozar sin ser sentidos desta no vista merced que el cielo en un mismo punto a los dos nos ha hecho. (CERVANTES, 2005, p. 649) BERGANZA. Cipión hermano, óyote hablar y sé que te hablo, y no puedo creerlo, por parecerme que el hablar nosotros pasa de los términos de la naturaleza. (CERVANTES, 2005, p. 649-50)

Para Berganza, essa dádiva repentina é algo inacreditável, pois se afasta de todo e qualquer preceito direcionado a conciliar a admiração, o elemento fantástico com a verossimilhança, até mesmo porque a fala canina não passa de algo inverossímil.

Desse modo, o propósito nesse episódio está em analisar detidamente as questões relacionadas a essa maravilha ou dádiva repentina e observar como o autor consegue conciliá-la com os princípios da verossimilhança. Além disso, é significativa a presença do gênero cômico, levando em conta quais as formas de que se vale para ser instituído na narrativa, isto é, qual o diferencial marcante que o distingue nesse instante da novela.

Conforme se desenrola o colóquio entre Cipión e Berganza, essa incredulidade aumenta à medida que os cães se propõem a descobrir as causas de tal prodígio. Essa afirmação se confirma na passagem em que Cipión levanta algumas possibilidades, tentando justificar o dom recebido: "Lo qué he oído alabar y encarecer es nuestra buena 
memoria, el agradecimiento y gran fidelidad nuestra; tanto, que nos suelen pintar por símbolo de la amistad [...]" (CERVANTES, 2005, p. 650).

Evidentemente, tais atributos poderiam justificar essa dádiva, embora os cães sentissem até certa incredulidade, espanto, de acordo com o fragmento a seguir: “CIPIÓN. [...] por donde me doy a entender que este nuestro hablar tan de improviso cae debajo del número de aquellas cosas que llaman portentos [...]" (CERVANTES, 2005, p. 651).

De fato, nos tempos de Cervantes esses temas fantásticos causavam admiração por se distanciarem dos princípios que norteavam as produções escritas do período, pois instituíam a necessidade de um discurso ficcional conter verossimilhança, apresentar argumentos convincentes, críveis, dentro de uma verdade possível.

Lembrando que esses preceitos tiveram seu ponto de partida no tratado de Poética de Aristóteles, sendo o filósofo o primeiro que tratou cientificamente de questões relacionadas à poética, tais como o conceito da verossimilhança e da admiratio $^{7}$. Dessa forma, Alonso López Pinciano, afirma em sua Philosophía Antigua Poética que:

[ ...] así soy de parecer que el poeta sea en la invención nuevo y raro; en la historia, admirable; y en la fábula, prodigioso y espantoso, porque la cosa nueva deleita y la admirable, más, y más la prodigiosa y espantosa; y el que no tuviere ingenio furioso harto y inventivo, añada a lo inventado, que la añadidura también tiene invención en cierta forma. (PINCIANO, 1998, p. 198)

Ao que concerne à verossimilhança, segundo o humanista, toda imitação deve contê-la, porque sua ausência significa que a poesia perde o ânimo e a forma. Nesse

\footnotetext{
${ }^{7}$ Aristóteles, em seu tratado de Poética, refere-se à admiração como efeito da imitação de feitos que causam temor ou compaixão, provenientes de algo inesperado, de caráter assombroso, ou seja, um feito não casual. (ARISTÓTELES, 2009, p. 57-8)
} 
aspecto, o poeta, para Pinciano, deve ser admirável, desde que não se afaste dos termos que aproximam seu discurso de uma verdade possível (p. 201), pois um texto que não apresente argumentos verossímeis tende a se transformar em algo disparatado, sem sentido.

Partindo dessa linha de raciocínio, é fundamental entender como esses princípios foram utilizados nas produções escritas do XVII, em especial na novela exemplar "El coloquio de los perros", analisando, em um primeiro momento, a importância da verossimilhança na obra ficcional do período, a fim de desvendar esse surpreendente diálogo canino.

Seguindo essa trajetória, pode-se dizer que a verossimilhança para a produção escrita daquele tempo, na visão contemporânea de Rogelio Miñana (2002, 2006, p. 24), concedia um papel de licitude à obra ficcional, tendo em vista que os textos deveriam conter uma verdade aparente, aprovada tanto pela Igreja quanto pela autoridade real. Ao citar Barry W. Ife (2002, 2006, p. 24), o pesquisador afirma que o estudioso analisou detidamente as consequências da leitura privada e o processo de legitimar a ficção e formar o receptor, distinguindo dois tipos de objeções contra essa escrita ficcional: a moral e a metafísica. Com respeito à moral, observa que nos séculos XVI e XVII as obras assumiam certa responsabilidade moral/exemplar perante seus leitores, porque dependendo da matéria apresentada, poderiam induzi-los a comportamentos ou afetos prejudiciais e, dessa forma, os incitaria poderosamente ao pecado. Por outro lado, para Ife, os argumentos metafísicos colocavam duas acusações contra a ficção. A primeira era que, por afastar-se dos modelos artísticos, o discurso ficcional colocava em risco a verdade como autoridade. A segunda consiste "[...] en la indeseable confusión entre verosimilitud y verdad histórica" (p. 25), porque a obra ficcional apresentava um tipo de produção escrita que muitas vezes coincidia com o texto histórico. A mudança começa 
no instante em que o ficcional adota uma verossimilhança distinta do texto histórico, porém tão legítima quanto este. Nesse sentido, enquanto a verdade histórica consiste em retratar os acontecimentos ocorridos, a poética se pauta na eficácia em expressar algo que possa ter ocorrido. Em outras palavras, "la verdad histórica enfatiza el contenido, lo que se dice; la poética enfatiza la expresión, el cómo se dice" (p. 53-4). Nessa configuração, para Miñana,

[...] lo verosímil es un concepto que participa por igual de lo que se dice y del cómo se dice, pues la organización de la historia y el estilo en que ésta se narra condicionan la verosimilitud del poema tanto como ejemplar, lo posible y lo creíble. (p. 75)

Assim, sejam quais forem os artifícios expressos na novela "El coloquio de los perros", no que se refere ao seu discurso ser ou não verossímil, é importante ressaltar que o próprio colóquio canino é inverossímil porque não há um discurso verdadeiro por meio do qual se possa estabelecer uma comparação para torná-lo verossímil, ou seja, não existem cães falantes. Se bem que, para certos autores antigos, a fala canina poderia ser crível a partir de gêneros e preceitos específicos. Um exemplo disso pode ser observado na obra de Luciano de Samósata, como em Diálogo dos mortos, composição em que mortos ilustres falam, ou $O$ amante da mentira, um ataque em um nível superficial a pseúdea (mentira ou ficção), reconhecendo sua "autonomia" perante os discursos verdadeiros, embora censure sua recepção equivocada.(LINS BRANDÃO, 2001, p. 48).

Para o pesquisador Lins Brandão, na obra intitulada A poética do hipocentauro, ao analisar detidamente os textos de Luciano, observa que a teoria dos gêneros para o autor ultrapassa a de Aristóteles, no momento em que não obriga os poetas a restringirem-se ao que poderia acontecer, libertando-os da "tirania" da verossimilhança. 
Ao praticar a ficção em prosa e "declarando que não passa de ficção", Luciano não faz referência somente ao que não foi visto nem ouvido, mas não se ocupa do possível. Para Lins Brandão,

Luciano "purifica" a tradicional liberdade de poetas, pintores e sonhos, livrando-a dos limites de uma determinada forma - definidora de certos gêneros de discurso, libertando-a da regra da verossimilhança: não o que aconteceu nem o que poderia ter acontecido, mas o que não pode, absolutamente, acontecer. (LINS BRANDÃO, 2001, p. 49).

Nesse sentido, para Luciano a "liberdade" dos poetas, pintores e sonhos consiste em poder criar coisas que não existem e "mostrar-se como liberdade" diante de uma verdade que "constrange a retórica, a filosofia e a história" (p. 50).

Entretanto, segundo Riley, mesmo utilizando um tema fantástico, como é o caso da fala canina, essa impossibilidade afetava Cervantes, pois o "Coloquio" é a única novela que trata de um tema realmente inverossímil. Por essa razão, o autor tratou de justificá-lo, seja pela afirmação de Cipión de que se trata de um prodígio, seja por entender que Campuzano, por estar em estado febril, tivesse sonhado ou delirado o diálogo canino. De uma maneira ou de outra, Cervantes apresenta certa meticulosidade (RILEY, 1981b, p. 301) com relação ao tema, tendo em vista que bastaria apresentar aos seus contemporâneos a novela como fábula moral, que estaria justificada. Assim, para demonstrar tal afirmação, é oportuno rever os estudos de Pinciano, contemporâneo de Cervantes, a respeito das fábulas apologéticas, uma vez que muitas delas continham animais que dialogavam com racionalidade.

[...] ]otras hay que sobre una mentira y ficción fundan una verdad, como las de Esopo, dichas apologéticas, las cuales, debajo de una hablilla, muestran un consejo muy fino e verdadero;[...] (PINCIANO, 1973, pp. 174-5) 
No entanto, desde o início da novela, seus protagonistas discutem a credibilidade dos acontecimentos, na intenção de fazê-los mais aceitáveis e instigantes, conforme as afirmações de Berganza:

Bien es verdad que, en el discurso de mi vida, diversas y muchas veces he oído decir grandes prerrogativas nuestras; tanto, que parece que algunos han querido sentir que tenemos un natural distinto, tan vivo y tan agudo en muchas cosas, que da indicios y señales de faltar poco para mostrar que tenemos un no sé qué de entendimiento capaz de discurso [...]. (CERVANTES, 2005, p. 650)

Nesse fragmento, Berganza observa que em função de os cães possuírem determinadas qualidades, possuem um direito natural que lhes dá a capacidade de entendimento e, consequentemente, a posse da fala. Assim, pode-se perceber que o autor, de certa maneira, emula o conceito de verossimilhança, pois a novela apresenta um feito inverossímil que se transforma em algo verossímil, no instante em que seus personagens procuram uma explicação plausível para o evento, como a sequência do diálogo:

BERGANZA. Bien sé que ha habido perros tan agradecidos que se han arrojado con los cuerpos difuntos de sus amos en la misma sepultura. Otros han estado sobre las sepulturas donde estaban enterrados sus señores, sin apartarse dellas, sin comer, hasta que se les acababa la vida. Sé también que, después del elefante, el perro tiene el primer lugar de parecer que tiene entendimiento, luego, el caballo, y el último, la jimia. (CERVANTES, 2005, pp. 650-1)

De acordo com o fragmento acima, o princípio de verossimilhança na novela começa a ser construído por intermédio de algumas suposições que as personagens levantam na tentativa de desvendarem esse elemento novo e surpreendente, mesmo que essa tentativa no sentido de justificar tal prodígio não seja suficiente para convertê-lo 
em algo verossímil, conforme as observação de Cipión: "[...] pero bien confesarás que ni has visto ni oído jamás que haya hablado ningún elefante, perro, caballo o mona [...]" (CERVANTES, 2005, p. 651).

O que chama a atenção na novela não é o dom da fala dos cães, mas a maneira como esse dom é trabalhado e conduzido por Cervantes (RILEY, 1981, p. 296), até mesmo porque o autor confia a narração dos episódios da novela a Berganza e Cipión, lhes permitindo esse pequeno poder $^{8}$. Assim, o autor delega tanto as questões envolvendo a verossimilhança do discurso quanto sua explicação a algum intermediário, seja ele um alferes de pouca credibilidade, sejam dois cães filósofos extasiados diante dessa fala tão inesperada.

Nesses termos, pode-se supor que o autor "joga" no interior da narrativa com as diversas interpretações dos protagonistas, a fim de justificarem o próprio colóquio canino, tornando-o mais aceitável e, ao mesmo tempo, mais atrativo ao leitor. Dessa forma, fica claro o esforço cervantino no sentido de chegar a um entendimento ou criar certa cumplicidade com esse leitor, no que diz respeito às questões envolvendo os critérios de verossimilhança presentes na novela.

Por esse motivo, nessa passagem do "Coloquio", as personagens procuram encontrar uma razão plausível para o dom recebido, instituindo uma série de conjecturas com o intuito de proporem uma justificativa para o injustificável.

CIPIÓN. [...] por donde me doy a entender que este nuestro hablar tan de improviso cae debajo del número de aquellas cosas que llaman portentos, las cuales, cuando se muestran y parecen, tiene averiguado la experiencia que alguna calamidad grande amenaza a las gentes. (CERVANTES, 2005, p. 651)

\footnotetext{
${ }^{8}$ RILEY, E. Teoria de la novela en Cervantes. Madrid: Taurus, 1981.
} 
Diante do comentário de Cipión é oportuno recordar que nos séculos XVI e XVII era crença popular que milagres ou prodígios poderiam ser prenúncios de um grande mal ou desastre. (CLOSE, 2006, p. 54) As pessoas daquele tempo acreditavam em sacrifícios humanos, em pessoas que através do olhar poderiam destruir colheitas, causar enfermidades, tanto em animais quanto em indivíduos.

Nota-se também, na referida passagem da novela, que o personagem direciona as explicações, com relação ao dom da fala, a um acontecimento extraordinário, no âmbito da admiração que envolve o elemento fantástico e assombroso.

Nessa linha, revendo o trabalho de Eduardo Urbina sobre o conceito de admiração e grotesco na obra Dom Quixote, no trecho em que retoma as análises de A. Forcione, referentes ao diálogo estabelecido entre o cônego e o cavaleiro andante, o pesquisador observa que um discurso disparatado pode se converter em admirável quando consegue gerar um estilo de verossimilhança que não se desvincula por completo dos preceitos aristotélicos, mas concede maior "independência" e mobilidade ao autor e ao personagem, como donos de seu próprio destino. (URBINA, 1989, p. 20).

Esse tipo de afirmação caminha na direção dos estudos feitos pelo pesquisador, os quais identificam as diversas variantes léxicas em que a admiratio se manifesta (admirar, admirável, admiração), como também os diferentes contextos, havendo a possibilidade de reconhecer e classificar a admiração em três categorias: positiva, negativa e ambivalente 9 (p. 21). No caso do "Coloquio", pode-se supor que a novela se caracteriza pela "admiração negativa", porque engloba todos os aspectos apresentados como expressão do maravilhoso no âmbito do inverossímil, embora se aproxime da “admiração positiva", levando em conta que em algumas ocasiões essa admiração seja

\footnotetext{
${ }^{9}$ Conforme Urbina, a admiração ambivalente é a justaposição das reações provocadas pelos outros dois tipos, ou seja, uma atitude dupla por parte de observadores e leitores, atuando simultaneamente como narradores e personagens.
} 
exemplo de extraordinário, de novo, daquilo que causa surpresa ou assombro pela novidade. Assim, para o pesquisador:

La admiración negativa proviene no sólo de lo feo o la deformidad física o mental, sino de aquello que carece precisamente de verosimilitud. Pude provocar la risa abiertamente, pero la reacción puede limitarse a la extrañeza, a la sorpresa producida por lo ridículo. (URBINA, 1989, p. 22)

Sendo assim, ao associar a admiração com o riso, esse tipo de manifestação faz com que o pesquisador retome as afirmações de Maggi, tratadista italiano do século XVI, referente a toda reação cômica que a admiração representa como expressão de algo maravilhoso, mas suprido de verossimilhança (1989, p. 22-3). Nesses termos, para melhor compreender essa proposição, é útil rever esses princípios com respeito à admiração e sua estreita relação com o risível.

De fato, para Maggi, o riso provém de toda a fealdade sem dor, a qual vem seguida da admiração. Por isso, toda fealdade está acompanhada da admiração e juntas elas causam o riso, podendo-se dizer que o cômico procede necessariamente da fealdade, mas com a intervenção da admiração. (PUEO, 2001, p. 240).

No caso dos cães cervantinos, o dom da fala se caracteriza por algo fantástico/maravilhoso, em função de seu caráter inverossímil. No entanto, no momento em que as personagens, através da admiração sentida, tentam desvendar as razões desse fato extraordinário, o diálogo assume características burlescas e o gênero cômico se presentifica na novela.

Paralelamente, observando-se o conceito de admiração presente em algumas obras do período contido entre os séculos XVI e XVII, cabe destacar os estudos atuais feitos por Antonio Armisen em seu artigo: “Admiración y maravillas en El criticón (más unas notas cervantinas)", e como essa análise se aproxima dos conceitos de 
admiração introduzidos por Cervantes nesta novela exemplar. Em seu trabalho, Armisen observa que autores como Baltasar Gracián na referida obra, Góngora em Soledades ou Calderón de la Barca em La vida es sueño, sem obviamente descartar Cervantes, aplicaram em seus discursos o conceito de admiração por intermédio de seus personagens. Dessa forma, essas personagens apresentavam afetos relativos ao êxtase e maravilhavam-se ou por entrarem em contato, por exemplo, com elementos da natureza, ou por estarem diante de situações que provocavam estranhamento, seja por pertencerem ao elemento novo, seja pelo desconhecimento de suas causas (ARMISEN, 2009, p. 204).

No caso da novela "El coloquio de los perros", essa admiração surge por meio do desconhecimento das possíveis causas que explicariam a fala dos cães; uma situação que instiga o leitor e o convida a desvendar esse elemento novo e desconcertante. O que conduz a inferir que o colóquio canino, mesmo sendo, em um primeiro momento, visto como algo fantástico e inverossímil, assume a posição, como diria Urbina, de uma história admirável e deleitosa, na qual o maravilhoso auxilia os impossíveis. Essa impossibilidade conduz a uma estranheza que tende ao riso e se baseia no princípio do deleite, o qual orienta sua verdade de acordo com "el entendimiento de los que la leyeren" (URBINA, 1989, p. 26), ou seja, a cumplicidade estabelecida entre autor e leitor.

Com base nas afirmações de Cipión, Berganza introduz o seguinte comentário:

BERGANZA. Desa manera no haré yo mucho en tener por señal portentosa lo que oí decir los días pasados a un estudiante, pasando por Alcalá de Henares.

CIPIÓN. ¿Qué le oíste decir?

BERGANZA. Que de cinco mil estudiantes que cursaban aquel año en la universidad, los dos mil oían medicina. (CERVANTES, 2005, p. 651) 
Nesse trecho da novela, é curioso verificar como o personagem procura não se comprometer com os comentários que faz. Ao relatar a Cipión sobre os futuros médicos, Berganza transfere a responsabilidade desse comentário a uma terceira pessoa, isto é, o que ouviu um estudante dizer quando passava por Alcalá de Henares. Pode-se supor que essa transferência não só o exime de todo e qualquer comprometimento, como também sugere certa inclinação cética do protagonista diante dessa temática que aborda fenômenos geradores de assombro, conforme a sequência do diálogo:

CIPIÓN. Pues ¿qué vienes a inferir deso?

BERGANZA. Infiero o que estos dos mil médicos han de tener enfermos que curar, que sería harta plaga y mala ventura, o ellos se han de morir de hambre. (CERVANTES, 2005, p. 651)

No fragmento acima, o ceticismo se confirma mediante a forma cômica utilizada por Berganza. No instante em que associa o excesso de futuros médicos com uma grande epidemia, revela, como diria Close, a existência de uma predisposição em afirmar que tais fenômenos sobrenaturais não passam de algo cômico e sem sentido (p. 54).

No que se refere ao excesso de estudantes de medicina, apontado pela personagem, conforme os estudos de Kenneth R. Scholberg sobre a sátira no século XVI (SCHOLBERG, 1979, p. 27), o pesquisador constata que o ato de satirizar determinados profissionais e tipos sociais nesse período desfrutou de certa popularidade, que vem desde a Idade Média até o século XVII. Nesse contexto, os médicos sempre foram alvo das mais severas censuras e os motivos se baseavam tanto no que tange ao aumento de "médicos" nesse tempo, uma vez que havia uma "botica" em cada esquina, quanto à imperícia desses profissionais, acusados de matar os enfermos (p. 27). 
Daí a se constatar que o discurso de Berganza, por apresentar um tom irônico, sugere também certa equivocidade, pois, ao utilizar o termo "harta plaga", pode referirse tanto a uma grande enfermidade quanto aos novos médicos serem uma "praga", ora no sentido de maldição, ora como designação geral de algo que vem em quantidade e é nocivo para a sociedade.

Mesmo assim, conforme o colóquio canino segue seu curso, esse conceito de admiração tende a enveredar por outro caminho. Na sequência, Cipión retorna com o tema do milagre, agora introduzindo um novo tom ao discurso: "Pero sea lo que fuere, nosotros hablamos, sea portento o no, que lo que el cielo tiene ordenado que suceda, no hay diligencia ni sabiduría humana que lo pueda prevenir." (CERVANTES, 2005, p. $651)$.

Nesse trecho da novela, Cipión deixa bem clara sua opinião a respeito da fala repentina de ambos, atribuindo o dom ao céu. O termo cielo, em posição metonímica, representa a figura de Deus, a onipotência de seu poder sobre a terra e sobre os homens. Assim, não há como questionar os desígnios de um poder supremo. O que se constata é que a fala da personagem introduz um preceito religioso pautado no poder de Deus sobre todas as coisas. Logo, as ações e causas não devem ser discutidas. Essas questões se aproximam dos preceitos de São Tomás de Aquino, ao fazer referência a forças desconhecidas ${ }^{10}$, conforme afirmação abaixo:

Como resulta claro por lo dicho, la Providencia Divina ejecuta sus acciones por medio de causas intermedias. La ordenación de estos efectos puede ser vista en un doble aspecto. 1) Uno. Según está en

\footnotetext{
${ }^{10}$ Cabe informar que a tradução de hado no dicionário RAE é: 1. Fuerza desconocida que, según algunos, obra irresistiblemente sobre los dioses, los hombres y los sucesos. 2. Encadenamiento fatal de los sucesos. Informação extraída em: http://www.rae.es. Acesso em: 2 jul. 2012.

Na mesma passagem, Santo Tomás de Aquino, citando Boécio, diz: "Que el hado se ejerce por ciertos ministros espirituales de la divina Providencia, o por el alma, o por la cooperación de la naturaleza entera, o por los movimientos celestes de los astros, o por virtud angélica, o por las artimañas de los demonios, o por algunas de estas cosas, o por todas ellas, así es como queda tejida la serie fatal”.
} 
Dios, y, bajo este aspecto, la ordenación de los efectos es llamada Providencia. 2) La otra. Pero si se considera esta ordenación de los efectos en cuanto está en las causas intermedias ordenadas por Dios a producir tales efectos, así es como se entiende el hado. [...] Por lo tanto, es evidente que el hado está en las mismas causas creadas en cuanto que están ordenadas por Dios a producir sus efectos. (AQUINO, 2012, questão 116, a.2)

Dessa forma, a fala de Cipión, instituindo certa autoridade, encerra toda a questão relacionada ao inesperado dom da fala, pois se por um lado esse prodígio introduz um tema que não permite conciliar o admirável com o verossímil, por outro lado, mesmo sendo algo inacreditável, o acontecimento assume características verossímeis em função de ser avalizado pelo poder divino, ${ }^{11}$ e este não admite maiores objeções.

Vê-se portanto, que a verossimilhança no "Coloquio" se constrói por intermédio das várias suposições que as personagens levantam na tentativa de desvendarem esse elemento novo e surpreendente, mesmo que essas tentativas no sentido de justificar a fala canina não sejam suficientes para ajustá-la dentro de uma ordem natural, dentro do possível, do crível. Com respeito a admiração na novela, o conceito tende a alguns estágios e definições, transitando do milagre ao portento, da virtude ao prodígio, sem contar que a relacionam com alguma calamidade ou acontecimento extraordinário.

No entanto, segundo Riley, essa admiração em Cervantes não se caracteriza nem através do prodigioso, nem pelo sobrenatural, mas mediante os acontecimentos extraordinários produzidos na vida cotidiana de seus personagens. Mesmo que esses

\footnotetext{
11 Com respeito a animais falantes, pode-se verificar o seguinte exemplo:"Na Bíblia, o asno é mencionado [...] em diversos contextos de maneira positiva, assim, a jumenta falante de Balaão representa a criatura capaz de entender, mais do que o homem, a vontade de Deus."

LEXICON, Helder Dicionário de Símbolos, São Paulo: Cultrix, 1998. p. 27.
} 
acontecimentos possam ser insuficientes, são os principais meios de que o autor se vale para proporcionar surpresas agradáveis aos leitores (1981b, p. 285).

Para Hansen, embora o caráter da obra se pauta justamente em toda a problemática inicial da novela com respeito à credibilidade de sua narrativa, o leitor reconhece que a verossimilhança do texto se compõem justamente na "figuração adequada do inverossímil", divertindo-se tanto com o engenho do autor quanto "com a maravilha da figuração." 12

Como diria a bruxa Cañizares a Berganza, em um episódio mais à frente: "Todo lo que nos pasa en la fantasía es tan intensamente que no hay que diferenciarlo de cuando vemos real y verdaderamente.” (RILEY, 1981, p. 304).

Nesse instante da novela, os cães percebem a necessidade de deixarem essas questões poéticas a serviço do aproveitamento desse dom.

CIPIÓN. [...] y, así, no hay para qué ponernos a disputar nosotros cómo o por qué hablamos; mejor será que este buen día, o buena noche, la metamos en nuestra casa, [...] sepamos aprovecharnos della y hablemos toda esta noche, sin dar lugar al sueño que nos impida este gusto, de mí por largos tiempos deseado.(CERVANTES, 2005, pp. 651-2).

Seguindo a opinião final de Cipión, ambos decidem narrar a história de suas vidas, a começar pelas peripécias do cão Berganza, as quais têm como ponto de partida seu nascimento no Matadouro de Sevilha.

\footnotetext{
${ }^{12}$ HANSEN, João A. Observação feita por ocasião da Banca de Defesa, em 10 mar. 2015.
} 


\title{
2. O episódio do Matadouro: uma narrativa engenhosa
}

\author{
Acostumbramos a cometer nuestras peores \\ debilidades y flaquezas a causa de la gente \\ que más despreciamos.
}

Charles Dickens

As produções letradas do século XVII se caracterizaram por instituírem um discurso que primava pelo engenho ou capacidade de invenção, responsável por apresentar em seu interior ornatos ou metáforas, cuja elaboração se deve à "faculdade intelectual do engenho" ${ }^{\prime 13}$, suficiente para produzir efeitos inesperados de admiração e maravilha em seu destinatário (HANSEN, 2006, p. 86). Nesses termos, de acordo com os estudos de João Adolfo Hansen, a metáfora assume algumas definições nesse período, tais como: agudeza, argúcia, conceito, conceito engenhoso; genericamente, entimema, silogismo retórico, ornato dialético e ornato dialético enigmático, partindo da afirmação aristotélica contida no De anima de que "qualquer discurso é metafórico por natureza, uma vez que os conceitos são imagens mentais que substituem os objetos da percepção" (p. 86).

Para o pesquisador, ao citar a Poética aristotélica, as metáforas que tornam a fala aguda e eficaz são próprias do orador e do poeta, pois "agudas são as expressões do pensamento que permitem um aprendizado rápido" (p. 86).

Diante de tais características, nossa análise se limitará a verificar no corpus selecionado desse subcapítulo do "Coloquio" os elementos relacionados tanto à

\footnotetext{
${ }^{13}$ HANSEN, João A. Agudezas seiscentistas.

Disponível em: http://periodicos.uesb.br/index.php/floema/article/viewFile/79/86.
} 
argumentação quanto à ornamentação do discurso, pois são artifícios utilizados por Cervantes na composição de uma escrita engenhosa e aguda ${ }^{14}$, que têm como possível intenção suscitar o riso. A proposta está em perceber como esses procedimentos retóricos se articulam nessa passagem da novela, cujo diálogo prima pela sutileza, pelo engenho, ao revelar tanto a capacidade intelectual desse autor quanto dos destinatários, conforme os estudos que se seguem.

Com o intuito de analisar essas questões, verifiquemos o início do episódio da novela no qual Berganza relata as reminiscências de sua vida, partindo de seu nascimento no Matadouro de Sevilha. No fragmento a seguir, o cão procura descrever os açougueiros, estabelecendo algumas analogias com seus pais:

BERGANZA. Paréceme que la primera vez que vi el sol fue en Sevilla y en su Matadero, [...] por donde imaginara, si no fuera por lo que después te diré, que mis padres debieron de ser alanos de aquellos que crían los ministros de aquella confusión, a quien llaman jiferos. (CERVANTES, 2005, p. 653)

De acordo com a declaração acima, o protagonista apresenta certa imprecisão com respeito à sua origem: "Paréceme que", "debieron de ser", imprecisão que se justifica por intermédio da observação anterior, "si no fuera por lo que después te diré", ou seja, prepara o ânimo de Cipión, possivelmente, para o episódio mais à frente, que descreve seu contato com a bruxa Cañizares, cujas declarações trarão uma provável explicação para o incrível dom da fala.

Outro aspecto a se considerar, seguindo no mesmo parágrafo, é que por meio da afirmação: "mis padres debieron de ser alanos de aquellos que crían los ministros de

\footnotetext{
${ }^{14}$ Engenho: É um "talento natural para a invenção [...] ordenado pelo juízo que pondera a deformação" (Hansen, João A. Ut pictura poesis e verossimilhança: a doutrina do conceito no século XVII colonial. $\mathrm{p}$. 184). Baltasar Gracián esclarece o conceito de agudeza: "consiste, pois, este artifício conceituoso em uma primorosa concordância, em uma harmônica correlação entre dois ou três cognoscíveis extremos, expressa por um ato do entendimento" (Hansen, João A. Agudezas seiscentistas, p. 88).
} 
aquella confusión, a quien llaman jiferos”, Berganza possa fazer uso de um entimema. Também chamado de silogismo imperfeito, o entimema representa uma das quatro partes da argumentação ${ }^{15}$ em que uma das premissas é omitida no discurso, a premissa menor. Como ornamentação do argumento, o entimema pode ser definido inclusive como argumentação bipartida, recebendo essa classificação em função de uma de suas partes permanecer subentendida, oculta.

Dessa forma, quando retornamos ao parágrafo, a frase descreve os pais do cão Berganza como sendo alanos, originários do cruzamento de duas raças de cães: dogue com galgo/lebréu (CERVANTES, 2005, p. 653). Lembrando que os cães alanos foram introduzidos na Europa no período das invasões bárbaras e, por serem ótimos tanto na caça quanto no ataque, tornaram seus donos famosos, isto é, o povo alano. ${ }^{16}$ Como se sabe, o povo alano, como outros povos, era tido como bárbaro pelos romanos, pois para eles todo "não romano" era chamado, pejorativamente, de "bárbaro", ou seja, incivilizado, cruel, selvagem. Seguindo nessa esteira, os cães alanos, pertencentes ao povo alano, percebido historicamente como bárbaro, premissa omitida na frase original, criaram os responsáveis por aquela confusão, os açougueiros. Nesses termos, tem-se a conclusão do entimema, ou seja, como os açougueiros foram criados pelos bárbaros, devem ser bárbaros.

Com essa elocução, torna-se evidente a ironia e a mordacidade de Berganza, pois o cão estabelece uma possível analogia dos açougueiros com o povo bárbaro, colocando suas ações no limiar do embrutecimento, da rusticidade. O fragmento não

\footnotetext{
15 Silogismo: Parte da argumentação composta de uma premissa maior, uma premissa menor e a conclusão. Extraído de: SOARES, Cipriano. Arte de retórica. Coimbra: João Barreira, 1562. p. 61.

${ }^{16}$ Os alanos, originários do nordeste do Cáucaso, eram nômades iranianos, pastores, que em função da destruição de seu império pelos hunos foram obrigados a migrar para outras partes da Europa. Extraído de: http://pt.wikipedia.org/wiki/Alanos. Acesso em: 8 nov. 2011.
} 
deixa de conter certa comicidade, mesmo porque o protagonista utiliza-se desse entimema para introduzir uma censura às práticas dos açougueiros do Matadouro.

É provável que Cervantes tenha feito uso desse estratagema com o objetivo de preparar o leitor para as coisas que lhe restavam por dizer. Nesse sentido, pode-se deduzir, já no início da história de Berganza com o primeiro amo, que tanto o espaço do Matadouro quanto seus frequentadores representam a alegoria do vício. Essa alegoria pode ser percebida como ornamento de um discurso implícito, cuja exposição ao leitor se dará à medida que são apresentados os acontecimentos da vida do protagonista.

Assim, para se alcançar os motivos da utilização desses procedimentos argumentativos nos textos do século XVII e sua aceitação pelos leitores desse período, deve-se levar em conta que, na época de Cervantes, as belas-letras estavam subordinadas a técnicas e métodos retóricos utilizados tanto na oralidade quanto na produção escrita, com o intuito de persuadir os ouvintes, apresentando "uma arte para bem dizer ou bem fazer: com brevidade, clareza e verossimilhança"17 (HANSEN, 2006, p. 44).

Com base nesse raciocínio, em seu livro Alegoria: construção e interpretação da metáfora, ao fazer alusão aos principais textos de retórica antiga, João A. Hansen afirma que brevidade e clareza são meios técnicos que visam tornar o discurso verossímil. Nesse aspecto, a alegoria recorre à clareza, pois esta é responsável por determinar maior ou menor aceitação das abstrações contidas no discurso. No que se refere ainda à clareza, a mesma se presentifica através de um conhecimento preestabelecido do ouvinte, articulado no interior do texto, facilitando não somente a compreensão do que está sendo dito, como também o reconhecimento desse "bom desempenho" (p. 46).

\footnotetext{
${ }^{17}$ HANSEN, João A. Alegoria: construção e interpretação da metáfora. São Paulo: Hedra/Unicamp, 2006.
} 
Desse modo, essa faculdade produzida pelo engenho do autor e percebida pelo receptor tende a correlacionar conceitos muitas vezes próprios de campos díspares do conhecimento, estabelecendo semelhanças a serviço do entendimento. Percebida como artifício, a agudeza integra certas práticas de representação presentes nos séculos XVI e XVII e se encontra no fundamento da inventio, a qual descobre, por meio da aplicação de ideias verossímeis, a probabilidade das questões contidas no discurso (SOARES, 1562, p. 5).

Seguindo esse raciocínio, é oportuno acrescentar que no século XVII acreditavase que esse engenho ou talento natural, presente nas produções letradas, era proveniente de um juízo iluminado pela "luz natural da Graça". Nesse aspecto, para se compreender a causa pela qual esse engenho era percebido como sendo proveniente da luz de Deus, é importante rever os preceitos quinhentistas de Juan Huarte de San Juan, ${ }^{18}$ em sua obra Examen de ingenios para las ciencias. Em seus estudos, o doutor Huarte de San Juan observa que esse engenho ou habilidade de imaginar nomes ou frases requer certo entendimento, isto é, uma potência gerativa, detentora de virtudes e forças naturais, direcionada a produzir um conceito ou verbum mentis que, conforme o estudioso,

[...] no sólo es lenguaje y doctrina recibida de los filósofos naturales decir que el entendimiento es potencia generativa, y llamar de hijo a lo que ésta produce; [...] Y, así, es cierto que de la fecundidad del entendimiento del Padre tuvo el Verbo divino su eternal generación. (HUARTE DE SAN JUAN, 1976, p. 427)

Além disso, no instante em que os filósofos naturais consideraram a grande fecundidade contida no entendimento de Deus, o chamaram de Gênio ou grande engendrador (SAN JUAN, 1976, p. 427).

\footnotetext{
${ }^{18}$ SAN JUAN, Juan Huarte de. Examen de ingenios para las ciencias. Madrid: Editora Nacional, 1976.
} 
Nesse sentido, Huarte retoma as ideias de Cícero para definir o engenho como uma qualidade própria de quem possui docilitas et memoria, isto é, facilidade para aprender e memória, que se reduz a uma palavra: engenho ou capacidade de engendrar, pois consiste em perceber o que a natureza diz e ensina com suas obras. Para Huarte de San Juan:

El que tuviere docilidad en el entendimiento y buen oído para percibir lo que la naturaleza dice y enseña con sus obras, aprenderá mucho en la contemplación de las cosas naturales: el que no, tendrá necesidad de preceptor que le avise y le haga considerar lo que los brutos animales y plantas están voceando. (p. 429)

Entretanto, no "Coloquio" há uma troca de papéis, uma vez que esse engenho, essa luz de Deus, ilumina o juízo desses protagonistas caninos, ao invés de se propagar nos seres humanos. Em consequência disso, instaura-se um distanciamento entre os cães e os demais personagens da novela retratados como irracionais e pecadores em função de suas ações e vícios. De fato, essa habilidade, essa agudeza pressupõe uma capacidade superior de entendimento. Para aqueles que não a possuem, seria como compará-los a um ser privado de um dos sentidos, que para Gracián ${ }^{19}$ é como se faltasse uma parte da vida, e assim “deja como manco el ánimo” (p. 54). De acordo com essas observações, tendo em vista o próprio colóquio canino, torna-se oportuno verificar a seguinte afirmação do autor: "Hay a veces entre un hombre y otro casi otra tanta distancia como entre el hombre y la bestia, si no en la sustancia, en la circunstancia; si no el la vitalidad, en el ejercicio de ella.” (GRACIÁN, 2004, p. 55).

Retomando as reminiscências de Berganza, o protagonista nos fala sobre seu primeiro amo, o açougueiro Nicolás el Romo ${ }^{20}$ : "El primero que conocí por amo fue uno

\footnotetext{
${ }^{19}$ GRACIÁN, Baltasar. El discreto y Oráculo manual y arte de prudencia. Barcelona: Delbosillo, 2004.

${ }^{20}$ Nicolás el Romo. O epíteto el Romo significa "nariz chato" (CERVANTES, 2005, p. 653).
} 
llamado Nicolás el Romo, mozo robusto, doblado y colérico, [...] como lo son todos aquellos que ejercitan la jifería." (CERVANTES, 2005, p. 653).

Como se observa pela construção textual, pode-se estabelecer uma espécie de distanciamento hierarquizante entre o protagonista e seu amo, produzindo certa comicidade em função dos elementos utilizados para tal fim. Nessa linha, quando descreve o açougueiro, Berganza faz uso do artigo indefinido "uno", instituindo certo tipo de imprecisão, um conhecimento vago e distante, sem qualquer associação, vínculo ou proximidade. Com respeito a Berganza, poder-se-ia supor que, em vista de sua condição natural, ou seja, por se tratar de um cão, o protagonista se coloca em uma posição inferior comparado com seres humanos. No entanto, de acordo com o desenrolar da narrativa, essa irracionalidade se centra nas práticas do próprio açougueiro, como se verá a seguir. Por esse motivo, Berganza censura a condição humana como se estivesse em um plano superior em comparação ao seu jovem amo, uma distinção que se presentifica por todo o episódio, através das exposições descritivas tanto do Matadouro quanto daqueles que ali conviviam.

Assim, pela descrição do açougueiro, tem-se o adjetivo "doblado" e sua primeira acepção: uma pessoa forte, de estatura mediana. Entretanto, de acordo com o Tesoro de la lengua castellana o española, de Sebastián de Covarrubias Orozco $^{21}$, o termo se caracteriza por "el que tiene una cosa en el corazón y otra en la lengua", ou seja, alguém pouco confiável, evidenciando cada vez mais a condição moral do açougueiro em função de suas falhas. Na sequência, Berganza expõe o personagem como um jovem "colérico", isto é, um indivíduo atacado pela ira, pela imoderação. A partir dessa observação, referente a um dos humores da medicina antiga, como é o caso do ser colérico, cabe recordar que os médicos naquele período, para melhor conhecerem a

${ }^{21}$ COBARRUBIAS OROZCO, Sebastián. Tesoro de la lengua castellana o española. Disponível em: google books, pdf. Acesso em: 6 fev. 2012. 
natureza do homem, suas funções e enfermidades, baseavam-se na teoria dos humores ou dos temperamentos. Isso se deve ao fato de que para se diagnosticar a causa das enfermidades os médicos faziam uso da teoria humoral, uma vez que as autópsias eram proibidas pela Igreja, pois entendia-se que essa prática era uma profanação do corpo humano. $^{22}$

Entretanto, retornando à descrição de Berganza, o homem colérico, do mesmo modo que possui inclinações para a sabedoria, a sutileza e o engenho, também se aproxima das extravagâncias, da destemperança e da invenção, com base nos fundamentos de Huarte de San Juan. Por isso, ao analisar a doutrina dos humores, o autor afirma que esses humores ou temperamentos podem se mesclar e, de acordo com a proporção de humores/fluidos contidos nessa mistura, surgem os temperamentos distintos. O caso de Nicolás el Romo possivelmente se aproxima desses preceitos. ${ }^{23}$

Sendo assim, para o protagonista, Nicolás é descrito como homem colérico, pois sustenta uma natureza violenta, cujas ações corrompem tudo ao seu redor. Não possui a capacidade para o engenho, porque seu temperamento consiste em uma mescla de humores que tende à irracionalidade.

Por conseguinte, tem-se que um homem colérico, como Nicolás, só é movido pela falta de entendimento, porque usa suas paixões sem qualquer moderação, seja pelo hábito, seja pelo exercício. Logo, em se tratando do açougueiro, pode-se inferir que essa cólera descrita por Berganza o direciona a práticas viciosas, tornando evidente a

\footnotetext{
${ }^{22}$ Certamente, ao contrário da visão moral que se sustentava desde a Idade Média, a doutrina humoral reaparece no Renascimento vinculada ao Humanismo, assumindo uma característica cortesã ao propor como paradigma o homem ideal. Nesse aspecto, essa doutrina estabelece quatro tipos de humores de acordo com os quatro componentes líquidos do organismo: a bílis amarela, a fleuma, o sangue e a bílis negra, correspondendo respectivamente aos quatro temperamentos: o colérico, fleumático, o sanguíneo e o melancólico. Esses humores eram responsáveis pela saúde ou doenças do organismo (MASSIMI, 2000, $\mathrm{s} / \mathrm{p})$.

23 " $[\ldots]$ de la manera que la sustancia gruesa del cerebro, y su mal temperamento, echan à perder el ingenio y así los espíritus vitales y sangre arterial, no siendo delicados y de buen temperamento, impiden al hombre su discurso y raciocinio" (SAN JUAN, 1976, p. 97).
} 
inexistência de qualquer disposição moral no jovem amo. Em outras palavras, a ausência de virtude em Nicolás não está relacionada aos seus afetos, que o tornam um homem colérico, mas porque os emprega de modo violento, sem comedimento, sem juízo.

Um exemplo disso está na passagem em que o protagonista descreve as responsabilidades do jovem açougueiro, não somente no tocante ao Matadouro e com respeito ao comércio irregular da carne, mas sobretudo com relação aos animais que ali viviam, como era o caso dos cães, ainda filhotes, como Berganza.

BERGANZA. Ese tal Nicolás me enseñaba a mí y a otros cachorros a que, en compañía de alanos viejos, arremetiésemos a los toros y les hiciésemos presa de las orejas. Con mucha facilidad salí un águila en esto. (p. 653)

É importante verificar o comentário de Cipión com relação a esses "ensinamentos" do açougueiro: "No me maravillo, Berganza; que el hacer mal viene de natural cosecha, fácilmente se aprende el hacerle." (CERVANTES, 2005, p. 653).

De acordo com a afirmação de Cipión, o "fazer mal” está na natureza humana, pois é algo inerente ao ser, e por essa razão o homem não necessita de grande intelecto para aprendê-lo e executá-lo. Para discorrer a respeito desse mal mencionado pelo protagonista, há que se pensar também no bem, uma vez que ambos os princípios estão sempre atrelados, interligados, não há como pensar em um esquecendo-se do outro.

Assim, para compreender melhor essas questões, torna-se útil rever os preceitos de Santo Tomás de Aquino ${ }^{24}$, pois para o teólogo, quando se acredita na existência do bem deve-se crer, também, na existência do mal. Entretanto, de acordo com a doutrina

\footnotetext{
24 AQUINO, Santo Tomás de. Suma teológica. Parte Ia, cuestiones 48-49. Disponível em: http://hjg.com.ar/sumat/a/c116.html. Acesso em 2 jul. 2012.
} 
cristã o mal não pode ser considerado como contrário do bem, pois não possui existência essencial. Assim, afirma Tomás de Aquino:

"(...), no nos queda más que decir que con el nombre de mal se indica una determinada ausencia de bien. Por eso se dice que el mal ni existe ni es bueno, porque como quiera que todo ser, en cuanto tal, es bueno, no existir y no ser bueno es lo mismo.(AQUINO, 2012, cuestiones 4849)

Como explicação, Tomás de Aquino cita o exemplo referente ao ser humano não possuir a velocidade de um cervo; a inexistência desse bem não o condena ao mal. Da mesma forma, esse homem pode apresentar ações más, porque o mal atua no instante que corrompe o bem.

No caso de "El coloquio de los perros", quando se examina a afirmação de Cipión a respeito das práticas humanas, percebe-se que o mal não era uma negação, mas uma privação do bem, pois como o açougueiro não possuía virtudes morais estava à mercê do pecado, estando propenso à corrupção.

Daí pode-se supor que a afirmação de Cipión sustenta o entimema lançado anteriormente pelo amigo Berganza, de que Nicolás el Romo, como os demais frequentadores do matadouro, eram bárbaros, no sentido pejorativo do termo, cuja acepção remete à irracionalidade animal. Essa animalização, esse desprestígio da condição humana, tende ao excesso, à falta de valores morais que evidenciam os pecados.

Na sequência, Berganza retrata o cotidiano do lugar com a chegada daqueles que de certa forma eram mantidos pelas carnes do matadouro. 
BERGANZA. Todas las mañanas que son días de carne, antes que amanezca están en el matadero gran cantidad de mujercillas ${ }^{25}$ y muchachos, todos con talegas, que, viniendo vacías, vuelven llenas de pedazos de carnes, y las criadas con criadillas y lomos medio enteros. (CERVANTES, 2005, p. 654)

Como se observa pela descrição de Berganza, as demais personagens secundárias do episódio são inomináveis, como: "las mujercillas y muchachos, los rufianes, la jifera dama de mi amo". Referendadas na novela ora pela profissão, ora por algum atributo que as qualifique ou degenere, essas personagens, em função da ausência do nome, são introduzidas na novela já com certo desprestígio, até mesmo se levarmos em consideração as acepções do termo inominável: baixo, reles, revoltante. Essas características do "Coloquio", no tocante aos personagens secundários, se farão presentes do início ao fim do relato; e esse distanciamento hierarquizante, como mencionado, se intensifica conforme o desenrolar da narrativa.

Nessa configuração, todas as descrições de Berganza, bem como os adjetivos utilizados, servem de argumentos que reforçam a opinião de Cipión a respeito do mal, pois sua prática é observada em todos os frequentadores do lugar. Dessa maneira, podese verificar como o protagonista descreve os personagens nesse instante da novela:

BERGANZA. Primero, has de presuponer que todos cuantos en él trabajan, desde el menor hasta el mayor, es gente ancha de conciencia, desalmada, sin temer al rey ni a su justicia, los más, amancebados. Son aves de rapiña carniceras. (CERVANTES, 2005, pp. 653-4)

O que se constata é a sequência de adjetivos empregados nessa passagem do "Coloquio", cujos termos qualificativos vão, gradativamente, caminhando rumo à desqualificação, tanto do açougueiro quanto dos indivíduos do matadouro. Ao

\footnotetext{
${ }^{25}$ Mujercillas: pícaras, prostitutas. In: CERVANTES, Miguel de. Novelas ejemplares. Madrid: Austral/Espasa, 2011. p. 242.
} 
acrescentar que são amancebados, ${ }^{26}$ o protagonista os retrata como seres que apresentam um desprezo total seja pelas doutrinas morais e teológicas seja pelos preceitos políticos da época.

Essa afirmação se justifica pela observância das diretrizes da política católica dos séculos XVI e XVII, em que o rei possuía poderes ilimitados e sua pessoa era tida como suprema. Esse poder não lhe era conferido diretamente de Deus, mas procedia dos súditos que se "alienaram de sua soberania ${ }^{27}$ " e a transferiram para o rei, subordinandose à sua vontade. Entretanto, é importante salientar que como rei católico suas ações estavam subordinadas à lei natural, pois se fosse contrariada ou contestada, sofreria a pena de ser deposto e até morto. (HANSEN, 2006, p.137-141)

Assim, conforme Hansen, o reino era constituído, ao retomar os preceitos de Tomás de Aquino, por meio da metáfora de um "corpo político". Nessa analogia ao corpo humano, o rei era a cabeça ou "razão suprema do reino" (HANSEN, 2006c, pp. 135-56); as demais partes desse corpo eram subordinadas a essa razão, com a finalidade de estabelecer harmonia e ordem ao todo ${ }^{28}$.

No que concerne à Igreja, esta possuía um poder paralelo ao do Estado, isto é, os preceitos políticos se fundavam nos religiosos, caracterizando o princípio pautado em uma fé, uma lei, um rei. Não seguir a religião real significava a privação dos direitos políticos e civis; não respeitar as leis reais, seja um grupo ou indivíduo, implicava em blasfêmia ou heresia, sob pena de ser extirpado. Cada indivíduo era subordinado à

\footnotetext{
${ }^{26}$ O casamento se legitima após o Concílio de Trento (1545 a 1563), em que se deu carta de natureza sacramental ao matrimônio. Havia o interesse do clero em impedir os matrimônios clandestinos, penalizando as relações pré-matrimoniais. Evitava-se que se consumassem casamentos realizados sem o consentimento paterno, apresentando o sacerdote uma postura conivente com os pais. Disponível em: http://www.artehistoria.jcyl.es/v2/contextos/1928.htm. Acesso em 7 jul.2014.

${ }^{27}$ HANSEN, João A. Educando príncipes no espelho.

Disponível em: http://periodicos.uesb.br/index.php/floema/article/view/81,pdf, 2006. Acesso em: 3 jan. 2013. p. 140.

${ }^{28}$ Idem. Para Hansen, “[...] a função de cada parte do corpo é servir de instrumento ao todo, do mesmo modo cada súdito individual ou cada ordem do reino devem integrar-se hierarquicamente, como obediência" (p. 141).
} 
cabeça real, definida sua "liberdade" como "servidão livre", conforme as afirmações de Suárez (1979, III, IV, p. 138), pois tudo visava a concórdia do corpo político do Estado (p. 138-9).

A liberdade cristã não consiste em estar isentos das justas leis humanas, nem em estar imunes da justa coação do castigo dos pecados quando se cometem contra a paz e a justiça; mas consiste em uma servidão livre, por amor e caridade, que não contradiz o regime humano, mas antes o ajuda, se efetivamente existe, e, se não existe, a supre com a coação. (SUÁREZ, 1979, III, IV) ${ }^{29}$

Seguindo nessa esteira, ao retornar à novela, quando Berganza declara que essa gente do Matadouro não teme nem ao rei nem à sua justiça, a afirmação subentende uma desqualificação geral, não só política, mas civil e religiosa, com relação a essas personagens. A frase de Berganza, em termos de construção textual, introduz argumentos de pessoa pautados na própria ação das personagens como forma de constituir seus feitos, casos relacionados, bem como argumentos relativos ao caráter que os identifica: se são bons, maus, perigosos, desonestos etc. (LÓPEZ GRIJERA, 1994, pp. 22-3) De fato, através desses argumentos, apresentados de forma implícita pelo protagonista, pode-se extrair que essa gente é herege e merece ser execrada em função das práticas assumidas, retratando a deformação moral que os caracteriza.

Entretanto, apesar dessa gente merecer a execração, não há qualquer tipo de punição a esses indivíduos, apenas uma censura severa, a qual apenas ridiculariza os personagens ao transformá-los em matéria de riso. Desse modo, o gênero cômico assume seu papel no interior do colóquio por intermédio da própria construção narrativa, no instante em que toda argumentação do protagonista tende a escarnecer o objeto de ataque, mas não feri-lo. Nesse contexto, ao rever os estudos modernos da obra

\footnotetext{
${ }^{29}$ Idem, p. 138.
} 
de Cervantes feitos por Antony Close em seu artigo Algunas reflexiones sobre la sátira en Cervantes, pode-se constatar que o cômico tanto pode ser benevolente com seu destinatário, transformando-o em motivo de riso inofensivo, lúdico, quanto mordaz e nocivo. Segundo o pesquisador, os enfoques são distintos, mas não contraditórios (CLOSE, 1999, p. 503), pois ambos tendem ao resgate de preceitos morais, perseguidos do início ao fim da novela.

Ao retomar o fragmento, com relação à linguagem proposta, é importante observar a metáfora utilizada na sequência: "aves de rapiña carniceras", termo que melhor retrata os membros do Matadouro na opinião de Berganza, embora os reduza mais uma vez à condição animal, ao compará-los com aves que se alimentam de carnes. Além disso, a frase é equívoca, pois se refere aos açougueiros ora pelo ofício, ora pelas práticas referentes ao roubo de carnes. Nesses termos, tem-se nesse momento do "Coloquio" a rapinagem relacionada ao roubo seguido de morte. Essa afirmação se sustenta no trecho em que Berganza descreve com admiração as ações predatórias dessa "buena gente":

BERGANZA. Pero ninguna cosa me admiraba más, ni me parecía peor, que el ver que estos jiferos con la misma facilidad matan a un hombre que a una vaca; por quítame allá esa paja, a dos por tres meten un cuchillo de cachas amarillas por la barriga de una persona como si acocotasen un toro. (CERVANTES, 2005, p. 654)

Evidencia-se nesse parágrafo da novela a analogia que Berganza faz entre o assassinato de um homem com o abate de um touro. A princípio, por serem açougueiros, pelo próprio ofício, pressupõe-se que a matança do gado é algo rotineiro, requer até certa habilidade como atributo de quem é competente no ofício. No entanto, ao se pensar em um crime, se está diante de um pecado, contrário às leis dos homens e à lei de Deus, a verdadeira personificação do mal, conforme Tomás de Aquino. Dessa 
maneira, segundo o teólogo, citando a Ética a Nicômaco de Aristóteles, matar um homem consiste no mal propriamente dito, não sendo lícito, mesmo que fosse um pecador. Entretanto, ao citar uma passagem da Bíblia, ${ }^{30}$ Tomás de Aquino ressalta que o homicídio é permitido quando direcionado a alguém que é perigoso à sociedade, no sentido de corrompê-la por algum pecado, sendo saudável tirar-lhe a vida para se conservar o bem comum. (Parte II, cuestión 64.)

Esse preceito foi mencionado para elucidar as questões contidas de maneira implícita nas reminiscências de Berganza ao referir-se às imperfeições morais dessa gente do Matadouro. O protagonista utiliza esse método de associação, a princípio, para apresentar uma simples descrição do ofício dos açougueiros, mas logo em seguida estabelece uma analogia entre as imagens da matança dos animais com os assassinatos ocorridos no local. O interesse não está em fixar a maneira como essas mortes acontecem, mas a facilidade e a destreza empregadas pelos personagens para tal fim.

Diante da construção narrativa da novela, observa-se que para o padre espanhol Cipriano Soares ${ }^{31}$, em um relato podem ser empregados certos artifícios de memória como forma de relacionar imagens eficientes a conceitos significativos, a fim de emocionar o espírito, marcando-o de um modo distinto. (p. 143).

Assim, por meio das imagens descritas dessa "buena gente" do Matadouro, Berganza reforça o caráter vicioso dos personagens, retratados como gente vil, ladrões mantidos como forma de suborno, pagos por aqueles que necessitam de proteção.

BERGANZA. [...] Todos se pican de valientes, y aun tienen sus puntas de rufianes; no hay ninguno que no tenga su ángel de guarda en la

\footnotetext{
${ }^{30}$ Essa passagem mencionada por Santo Tomás de Aquino refere-se a Coríntios I, versículos 5-6. Disponível em: http://www.bibliaon.com/1_corintios_5. Acesso em: 5 mar. 2012.

${ }^{31}$ SOARES, Cipriano. Arte de retórica. Coimbra: Ed. João Barreira, 1562.
} 
plaza de San Francisco, granjeado con lomos y lenguas de vaca. (CERVANTES, 2005, p. 655)

Sem dúvida, o Matadouro, pela descrição do protagonista, representa a alegoria de um estado hostil, de um território a ser dominado, onde, segundo a opinião do jovem mastim, "todos tienen sus puntas de rufianes" (p. 655). Apesar de Berganza retratar as práticas reprováveis dos frequentadores do Matadouro, censurar um estamento social do qual pertence tanto por nascimento quanto por convivência, sem esperar qualquer mudança ou transformação moral, apresenta em seus relatos certa ironia, um tom que tende à comicidade, transformando o que poderia ser um discurso moralizador em uma narrativa divertida, muitas vezes mordaz.

Com efeito, pode-se notar pelo relato do protagonista que as ações vão sendo construídas em um sentido crescente, ou seja: à medida em que a descrição dos frequentadores do Matadouro avança no interior do discurso, pouco a pouco aumenta a gravidade dos vícios; de atos de vileza e pequenos furtos, agora Berganza os associa a crimes como subornos e assassinatos. Daí a necessária intervenção real, segundo o protagonista: "Finalmente, oí decir a un hombre discreto que tres cosas tenía el rey por ganar en Sevilla: la calle de la Caza, la Costanilla y el Matadero.” (CERVANTES, 2005, p. 655).

Dessa forma, a comicidade se presentifica, como mencionado anteriormente, através da própria construção textual. Por intermédio da utilização de um entimema, metáforas e frases de efeito, o discurso tende a um estilo agudo, engenhoso. Um verdadeiro deleite sem saturação, com a finalidade de descrever todo o espaço do Matadouro.

Deve-se ainda relembrar que toda essa estratégia de composição apresentada por Cervantes só é possível em função de um conhecimento prévio dessas sutilezas por 
parte de um receptor, cujas habilidades e entendimento desvendam todas as agudezas contidas nesse diálogo narrativo. 


\section{A relação mestre e discípulo - o riso através das censuras de Cipión}

La raza humana tiene un arma

verdaderamente eficaz: la risa.

Mark Twain

Na Espanha do século XVI se compôs uma grande quantidade de diálogos em prosa, cujas fontes remetem aos diálogos italianos e aos colóquios de Erasmo de Rotterdam. Da segunda década dos anos 1500 até seu final, surgiu uma produção escrita que continha diálogos filosóficos, religiosos, morais, satíricos, históricos, científicos, técnicos, artísticos e de passatempo, ou seja, uma multiplicidade de modelos e temas, perseguindo uma quantidade de interesses e doutrinas expressas em uma forma constante (MURILLO, 2006, p. 28).

Assim, como um instrumento prático e especulativo, o diálogo institui uma forma de aprendizagem, compreensão e raciocínio, baseando-se na concepção de mundo característica de sua época. Dessa maneira, ao estudar os elementos constitutivos dos diálogos renascentistas, pode-se notar que estes já estabeleciam certo afastamento com respeito à "concepção de homem e do mundo teocêntrica e sobrenatural da Idade Média", ao conceder uma religião no interior da alma individual, superando-a com outra percepção natural e racional do todo humano. (MURILLO, p. 28).

Nessa configuração, através de seus estudos sobre o diálogo e a dialética no século XVI, Luis Andrés Murillo (p. 34), ao analisar a novela exemplar "El coloquio de los perros", observa em seu texto uma nova arte de narrar. Isso se deve ao fato de a novela apresentar toda a estrutura dialética do diálogo, com uma substância crítica e 
racional submetida à ironia, bem como a transformação engenhosa da verossimilhança contida em cenas fantásticas que irão compor essa narrativa diálogo.

Dessa forma, por intermédio da história de vida do cão Berganza, narrada ao amigo e interlocutor Cipión, os personagens estabelecem um diálogo cômico, muitas vezes com características satíricas, a fim de introduzir uma censura moral, baseada nas experiências e peripécias passadas pelo protagonista durante seu convívio com cada um dos personagens secundários.

No entanto, em seu afã de narrar todos os acontecimentos relacionados ao mundo vicioso que o permeia, Berganza muitas vezes estende consideravelmente sua narrativa, embora Cipión sempre intervenha com respeito à extensão desse discurso, pois esta dádiva pode ser retirada a qualquer instante.

Além disso, Cipión emite uma censura às reminiscências de Berganza, entre outras questões que serão analisadas mais adiante, referindo-se à quantidade de minúcias ou casos relacionados, a fim de que o amigo apresente um discurso cujos argumentos não excedam uma certa medida. Essa medida, no interior da narrativa, refere-se ao tempo necessário para sua exposição, sem acréscimos, sem a redução de elementos indispensáveis, do contrário o discurso tenderia a transformar-se em um texto repleto de digressões.

Um exemplo disso pode ser encontrado na passagem em que Berganza faz um longo comentário a respeito das características tanto físicas quanto morais dos açougueiros do Matadouro. Diante de tão longa exposição, Cipión faz sua intervenção, conforme o parágrafo a seguir:

CIPIÓN. Si en contar las condiciones de los amos que ha tenido y las faltas de sus oficios te has de estar, amigo Berganza, tanto como esta vez, menester será pedir al cielo nos conceda la habla siquiera por un 
año, y aun temo que, al paso que llevas, no llegarás a la mitad de tu historia. (CERVANTES, 2005, p. 655)

Para que se possa compreender as preocupações de Cipión com respeito à extensão da narrativa de Berganza, ou seja, o emprego das digressões, deve-se verificar o que vem a ser digressão. Em seu estudo sobre a digressão na prosa narrativa de Lope de Vega, Gonzalo de Sobejano ${ }^{32}$ afirma que a digressão é um conceito que se caracteriza por "sair do caminho" de um discurso poético ou narrativo, regressando a ele (p. 2-3). Nesse aspecto, para o autor,

[...] la digresión podrá cumplir alguna de estas funciones: enseñar (digresión instructiva), embellecer o amenizar (ornamental), comentar reacciones o conductas (moral), o en fin, hacer reflexionar sobre la actividad misma del narrar, enjuiciándola a distancia (digresión reflexiva). Cualquiera que sea la función, su efecto consiste en retardar la narración principal, provocando en los mejores casos una tensión estimulante, en los peores una dilación fastidiosa. (SOBEJANO, 2010, p. 3)

Certamente, as prevenções de Cipión consistem em Berganza não instituir um discurso que contenha tantas digressões que provoquem não somente a perda de unidade e coerência do trabalho expositivo, mas despertem certo fastio em seu receptor.

Nessa configuração, ao tratar da convenção da brevidade em um discurso expositivo, em seu livro Alegoria, construção e interpretação da metáfora ${ }^{33}$, João Adolfo Hansen afirma que um orador antigo captava a benevolência de seus destinatários através da brevidade do discurso, pois esta facilitava a compreensão do trabalho expositivo, sua memorização. "Transpostas para a produção poética, brevidade e clareza geralmente visam evitar hibridismos que infringem a preceptiva de sua pureza

\footnotetext{
${ }^{32}$ SOBEJANO, Gonzalo. La digresión en la prosa narrativa de Lope de Vega y en su poesía epistolar. Disponível em: http://www.biblioteca.org.ar/libros/155189.pdf. Acesso em: 31 jul. 2013.

${ }_{33}$ HANSEN, João Adolfo. Alegoria: construção e interpretação da metáfora. Campinas: Editora da Unicamp, 2006. pp. 45-7.
} 
estilística repartida em gêneros" (pp. 46-7), pois a clareza e a brevidade eram determinadas pela "conveniência e adequação do discurso às tópicas e ao gênero". (p. 47). No entanto, segundo o pesquisador, o público espanhol, francês e português do século XVII admirava os sermões longos aos moldes de Vieira, Gracián e Bossuet, com "sua intrincada combinatória sintática", cujos escritos iam pregando qualidades recortadas de categorias aristotélicas e escolásticas, efetuando "o conceito ou agudeza" (HANSEN, 2006, p. 46).

Em outros aspectos, retornando ao "Coloquio", conforme observado por Maria Augusta da Costa Viera, em seu artigo sobre La discreción de Cipión (2011, p. 108), o cão interlocutor introduz à enunciação de Berganza a análise, a ponderação e a crítica, ou seja, uma "metaescritura", levando em conta não somente os efeitos produzidos pelo relato de seu companheiro canino, como também os mecanismos de produção, a fim de detectar as ocorrências digressivas tidas como verdadeiros apêndices no discurso, repletos de observações marginais. Segundo a pesquisadora, Cipión acompanha o relato, advertindo todas as vezes que surgem as digressões. Responsáveis por direcionar a narrativa por caminhos viciosos próprios do sermão, as digressões eram encontradas em algumas novelas picarescas, em um certo tipo de sátira evitada por Cervantes e na murmuração. Dessa forma, Cipión institui certas advertências para "que el relato no se deslice por senderos múltiples que al fin y al cabo podrían conducir a las vías del vicio" (p. 109).

Paralelamente, em seu trabalho "Género y estrutura de 'El coloquio de los perros"”, Antonio Rey Hazas ${ }^{34}$ observa que estes conselhos de Cipión orientam Berganza no sentido de não instituir uma narrativa aos moldes de certas novelas

\footnotetext{
${ }^{34}$ REY HAZAS, Antonio. "Género y estructura de 'El coloquio de los perros', o cómo se hace una novela". Lenguaje, ideología y organización textual en las Novelas Ejemplares - Actas del "Coloquio" celebrado en la Facultad de Filología de la Univesidad Complutense en mayo de 1982. Madrid: Universidad Complutense; Toulouse: Université de Toulouse- Le Mirail, 1983.
} 
picarescas, que interrompem a autobiografia de seus protagonistas com uma quantidade infindável de digressões, reflexões, anedotas, exemplos, fábulas, contos etc., como é o caso de Guzmán de Alfarache, de Mateo Alemán. Para o pesquisador, Cervantes

[...] no puede admitir semejante concepto de la novela-pulpo, plagada de colas que la desvían de su principal intención, más semejante, por ello, a los sermones de los predicadores que a una verdadera narración. (REY HAZAS, 1983, pp. 131-2).

Para Rey Hazas, Cervantes não pode aceitar o uso exagerado de digressões em detrimento do percurso narrativo. Por essa razão, sua paródia não ridiculariza as novelas picarescas de uma maneira geral, mas as interpolações desmedidas observadas em certas obras, como é o caso de Mateo Alemán e Francisco López de Úbeda. (REY HAZAS, 1983, p. 132). Além disso, torna-se mais compreensível a censura de Cipión à Berganza referente à convenção da brevidade em sua narrativa, pois a orientação consiste em comover os ouvidos e o espírito daqueles que recebem um trabalho expositivo, ora pela fala, ora pela escrita, com o intuito de introduzir certa moderação no ato de se expressar através da palavra.

Nesse aspecto, Cipión segue com sua fala e introduz, através da advertência abaixo, todo um princípio com respeito à maneira de como se deve compor e apresentar um conto:

CIPIÓN. Y quiérote advertir de una cosa, de la cual verás la experiencia cuando te cuente los sucesos de mi vida; y es que los cuentos unos encierran y tienen la gracia en ellos mismos; otros, en el modo de contarlos; quiero decir que algunos hay que aunque se cuenten sin preámbulos y ornamentos de palabras, dan contento; otros hay que es menester vestirlos de palabras, y con demostraciones del rostro y de las manos y con mudar la voz se hacen algo de nonada, y de flojos e desmayados se vuelven agudos y gustosos. (CERVANTES, 2005, p. $655)$ 
Com essa advertência, Cipión, como um mestre, apresenta uma espécie de modelo teórico com respeito à arte de narrar, direcionando as falas de Berganza no sentido de promover uma narrativa deleitosa, apartada das digressões fastidiosas, cujos excessos de argumentos acabam estabelecendo para o leitor certa dificuldade, no que se refere ao processo interpretativo da obra.

De maneira idêntica, em seu livro Aspectos de la novela en Cervantes, no capítulo que analisa a enunciação, níveis, vozes e perspectiva, ao tratar da novela "El coloquio de los perros", Antonio Garrido Dominguéz ${ }^{35}$ conclui que se está diante de uma novela exemplar, levando em conta a doutrina disseminada ao longo de seu texto, seja referindo-se aos aspectos morais, tais como referências à mentira, à fala maledicente, seja principalmente, no que concerne ao plano técnico da arte narrativa, bem como sobre o comportamento do narrador. ( GARRIDO DOMINGUÉZ, 2007, p. 87).

Diante da referida passagem do "Coloquio", o que se pode dizer é que Cipión apresenta uma posição, dentro da novela, de certa superioridade com relação ao papel “menos sábio" de Berganza (REY HAZAS, 1983, p. 130). Suas advertências não se restringem apenas às opiniões do companheiro com respeito ao comportamento das personagens descritas, mas ele observa a descontinuidade intencional de seu discurso, como é o caso das digressões, permeadas pela fala tendenciosa própria do universo da murmuração. Nesse aspecto, há momentos em que o próprio discurso de Cipión assume um tom moral, com frases filosóficas e de efeito, com o propósito de evitar as extensas e maliciosas descrições de Berganza relativas ao universo do Matadouro.

\footnotetext{
35 GARRIDO DOMINGUÉZ, Antonio. Aspectos de la Novela en Cervantes. Madrid: Ediciones del Centro de Estudios Cervantinos, 2007. Disponível em: http://books.google.com.br/books?id=wmxmSoRM2mcC\&printsec=frontcover\&hl=ptBR\&source=gbs_ge_summary_r\&cad $=0 \# v=$ onepage $\& q \& f=$ false
} 
O efeito cômico se dá, nesse subcapítulo da novela, através da erudição introduzida por Cipión. Ao instituir certo didatismo em seu discurso, o cão introduz um diálogo com características doutrinais, pois, como um sábio ou mestre, resolve as disputas suscitadas no "Coloquio" e submete os temas discutidos à sua justa apreciação (REY HAZAS, 1983, p. 130). Assim, baseando-se em seus estudos Rey Hazas afirma que:

[...] Cervantes proyecta de manera especial la atención del lector sobre los comentarios de dicho perro, que, curiosamente, no cuenta su propia vida. Es decir, que ha incluido dentro del Coloquio un narrador de ascendencia picaresca y un crítico, a quien va directamente dirigida la novela, con lo que el lector real, el que está fuera del texto, encuentra una primera directriz interpretativa. (p. 130)

Sem dúvida, Cipión expressa seus comentários/conselhos, apesar de Berganza confessar suas dificuldades: "Yo lo haré así, si pudiere y si me da lugar la grande tentación que tengo de hablar, aunque me parece que con grandísima dificultad me podré ir a la mano.” (CERVANTES, 2005, p. 655).

Com base nessa fala do protagonista, Cipión faz outra advertência:” Vete a la lengua, que en ella consisten los mayores daños de la humana vida." (CERVANTES, 2005, p. 656). É oportuno verificar uma opinião atribuída ao próprio Cervantes, a fim de compará-la com essa fala de Cipión:

La pluma es lengua de la mente, aunque en la lengua consisten los mayores daños de la vida humana, ciertamente, la pluma es lengua del alma; cuales fueren los conceptos que en ella se engendraron, tales serán sus escritos. ${ }^{36}$

\footnotetext{
${ }^{36}$ Frase disponível em: http://html.rincondelvago.com/miguel-de-cervantes-saavedra_1.html 87344 bytes. Acesso em: 14 mar.2012.
} 
Essa afirmação do autor se aproxima de outra feita no capítulo XXXI da segunda parte de Dom Quixote, quando o cavaleiro adverte Sancho no sentido de "frear a língua" antes de usar palavras fora de seu propósito:

Enfrena la lengua, considera y rumia las palabras antes que te salgan de la boca, y advierte que hemos llegado a parte donde con el favor de Dios y valor de mi brazo hemos de salir mejorados en tercio y quinto en fama y en hacienda. (CERVANTES, 2004, p. 787)

Tanto a fala de Cipión quanto a de Dom Quixote possivelmente descrevem a opinião de Cervantes. Essa opinião se presentifica na referência que faz à falta de prudência, seja nas falas seja nas ações, uma advertência feita pelo personagem que retoma a questão do discurso sem brevidade, incentivado pelo tropel das ideias, dos detalhes que envolvem o tema, algo exaltado sem qualquer comedimento, uma exibição de acontecimentos, que tende a se aproximar da imoderação, do ridículo, rumo ao universo do cômico.

Berganza continua a narrativa de suas peripécias e recorda o momento em que Nicolás o ensinou a levar uma espécie de cesto com um pedaço de carne à casa de uma de suas amigas, bem como defendê-lo contra aqueles que quisessem tirá-lo.

BERGANZA. [...] mi amo me enseño a llevar una espuerta en la boca y a defenderla de quien quitármela quisiese. Enseñome también la casa de su amiga, y con esto se escusó la venida de su criada al matadero, porque yo le llevaba las madrugadas lo que él había hurtado las noches. (CERVANTES, 2005, p. 656)

Entretanto, Berganza seguia em sua tarefa, quando algo o detém, conforme o fragmento abaixo:

BERGANZA. [...] iba yo diligente a llevarle la porción, oí que me llamaban por mi nombre desde una ventana; alce los ojos y vi una 
moza hermosa en extremo; detúveme un poco y ella bajó a la puerta de la calle y tornó a llamar. (CERVANTES, 2005, p. 656)

Essa passagem do "Coloquio" faz referência a uma jovem prostituta, cuja beleza cria certo impasse, um obstáculo colocado no caminho de Berganza a fim de desviá-lo de seu objetivo. No entanto, em virtude do ofício da jovem, o protagonista se detém com um misto de desconfiança e incerteza, como se estivesse diante de um dilema: atender ou não ao chamado. Essas questões causam preocupação ao protagonista, pois elas estariam contrárias aos princípios voltados ao dever, ao desejo de empreender uma tarefa para a qual foi treinado e designado.

Mesmo desconfiando das atitudes da bela dama, Berganza decide atender ao chamado: "Llegueme a ella como si fuera a ver lo que me quería, que no fue otra cosa que quitarme lo que llevaba en la cesta y ponerme en su lugar un chapín viejo.” (p. 656).

A atitude da jovem dama só reforça uma certeza no protagonista: não poderia esperar outra atitude, afinal, tratava-se de uma das "amigas" de seu amo, sem contar o ofício que mantinha, ou seja, a prostituição. Daí, pode-se esperar qualquer vileza. Na sequência, é interessante verificar as falas do jovem mastim: "Entonces dije entre mí: La carne se ha ido a la carne." (CERVANTES, 2005, p. 656).

Diante de tal declaração o que se constata é que no início da frase o termo “carne” relaciona-se à porção de carne animal enviada por Nicolas. No entanto, no segundo momento da oração, a palavra se decompõe em dois conceitos: o primeiro faz referência à carne humana, o segundo, provavelmente, assume um sentido pejorativo, quando o termo apresenta a função de ornato dialético ao associar o substantivo à noção de corpo/sexo, referindo-se ao ofício da jovem dama. A frase é aguda, pois, como diria Hansen $^{37}$ em seus estudos sobre o uso da agudeza nas composições do século XVII:

\footnotetext{
${ }^{37}$ HANSEN, João A. Retórica da agudeza. Disponível em: http://pt.scribd.com/doc/59088666/Retoricada-Agudeza-Hansen. Acesso em: 20 out. 2011.
} 
“[...] a agudeza resulta de uma operação dialética, como análise, e de uma operação retórica, como elocução, tropo ou figura; os preceptistas do século XVII costumam chamá-la de "ornato dialético".” (p. 318).

Nesse aspecto, para melhor compreender como se articulam essas questões referentes às agudezas contidas em determinadas produções escritas do XVII, inclusive na obra cervantina, até se chegar ao conceito de ornato dialético, devem ser revistos os estudos de João A. Hansen contidos em sua obra A sátira e o engenho, no capítulo em que analisa "O ornato dialético e a pintura do misto". Em suas análises, o pesquisador observa que até o final do século XVI, para se compor, por exemplo, um poema, o autor selecionava os temas obtidos por intermédio de uma escolha prévia, evidentemente levando em conta o gênero que iria representar. ${ }^{38}$ A disposição desses temas deveria ser ordenada logicamente e seus ornamentos utilizados de forma ponderada. Em fins do século XVI e no século XVII,

o funcionamento retórico da poesia antiga muda quanto à clareza e à congruência na poesia que hoje se conhece como "barroca" $[\ldots]$ a elocução e seus ornamentos passam a preencher os lugares tradicionais da invenção poética: a poesia passa a ser produzida como desenvolvimento ornamental de ornamentos de base. (HANSEN, 2004, p. 304)

Nesse sentido, o conceito torna-se "elocução engenhosa" ou "ornato dialético 39", que, conforme o pesquisador, é um termo “[...]de grande polissemia e várias aplicações, muitas vezes equivalente a agudeza, entimema, silogismo retórico, também nomes do efeito de maravilha." (HANSEN, 2004, p. 304).

\footnotetext{
${ }^{38}$ HANSEN, João A. A sátira e o engenho. 2 ed. São Paulo/Campinas: Ateliê Editorial/ Editora da Unicamp, 2004. p. 304.

${ }^{39}$ Idem, p. 304.
} 
Dessa maneira, as belas-letras começam a ser valorizadas não pela simplicidade de seus ornamentos, mas pela complexidade da relação "imagem/conceito", porque produz um novo conceito que, sendo imagem, "traduz muito indiretamente o conceitoimagem" ou "definição-ilustrada". Os temas, como imagens de conceitos ou metáforas, se apresentam com “infindáveis variações”(p. 304). Dá-se assim a passagem da metáfora de "simples tropo de estilo para a base da representação poética visual; as imagens obtidas tornam-se o centro do conceito engenhoso (p. 304).

Daí a expressão de Berganza ser proveniente de uma agudeza percebida como "imagem-conceito", a qual subdivide a palavra "carne" em dois conceitos distintos, como mencionado. Proveniente de um engenho ou talento natural, no caso de Cervantes, a agudeza é introduzida na frase do protagonista de forma repentina, e sua presença causa admiração/maravilha. O que leva à conclusão de que essa técnica, ao ser instituída na construção textual, valoriza a elocução apresentada, identificando a excelência da composição.

Além disso, a frase do protagonista assume certa carga de ironia e maledicência que tende ao riso, tanto em função da agudeza apresentada quanto com respeito à vileza da jovem dama, cuja representação se dá por intermédio de ações movidas por afetos de ciúme e vingança. Assim, no momento em que rouba o jovem mastim, a prostituta reafirma essas paixões por meio de uma ação torpe e desonesta. A torpeza está não somente no roubo, mas no propósito de agredir indiretamente Nicolás, mesmo que para tal fim as consequências de seu ato recaiam sobre o pobre cão. Diante disso, a dama assume uma postura jocosa e faz uma advertência ao protagonista: “Andad, Gavilán, o como os llamáis, y decid a Nicolás el Romo, vuestro amo, que no se fie de animales y que del lobo un pelo, y ése, de la espuerta.” (CERVANTES, 2005, p. 656). 
O que se pode verificar no fragmento acima é que o termo lobo em germanía (gíria utilizada pela delinquência da época) significa "ladrão", cuja utilização feita pela jovem tem como intuito reforçar sua advertência à Berganza, sob o disfarce de um conselho, ou seja: não se fie de um ladrão. A vileza da jovem faz com que Berganza se sinta motivado em avançar com violência, mas se detém diante da razão: "Bien pudiera yo volver a quitar lo que me quitó, pero no quise por no poner mi boca jifera y sucia en aquellas manos limpias y blancas.” (CERVANTES, 2005, p. 656).

Deve-se, ainda, verificar que a frase apresenta dois sentidos simultaneamente válidos; a princípio o uso do adjetivo "jifera" associado ao substantivo "boca" remete ao ofício de seu amo: "la jifería". No entanto, a locução adjetiva "boca jifera" também assume um tom pejorativo, referindo-se ao sujo, ao vil, um desprestígio para com os personagens envolvidos - elementos que se contrapõem às descrições e características das mãos da bela dama: "limpias y blancas".

No que concerne à jovem dama, é importante acrescentar que as mãos brancas, juntamente com outros atributos, constituíram um ideal de beleza feminina na Idade Média que se manteve até a Idade Moderna. Um exemplo disso pode ser encontrado no poema de Juan de Encina (1469-1529) em que o autor espanhol enaltece a antiga tradição retórica ao descrever "de arriba abajo, parte por parte, a su amiga". (Juan de Encina alabando a su amiga porque le preguntaban quién era.) ${ }^{40}$

\section{[...]}

Los brazos $[\ldots]$ los tiene bien fornidos;

las manos angelicales,

celestiales,

\footnotetext{
${ }^{40}$ Poema

disponível em: http://www.biblioteca-antologica.org/wp-content/uploads/2009/09/CANCIONERO.pdf.
} 
delgadas largas y blancas $[\ldots]^{41}$

Observa-se ainda que em algumas obras cervantinas, "las manos blancas" são mencionadas como um traço distintivo das personagens femininas. Cito como exemplo a novela "El casamiento engañoso", na passagem em que a personagem Estefanía se apresenta ao alferes Campuzano: "[...] sin dejar ver el rostro más de aquello que concedía la raridad del manto. [...] sacó la señora una muy blanca mano con muy buenas sortijas." (CERVANTES, 2005, p. 631).

Outro exemplo pode ser percebido em Dom Quixote, Parte II, capítulo XXXII, no episódio dos duques, no instante em que quatro donzelas chegam para lavar a barba do cavaleiro andante, o qual acredita ser essa cerimônia um costume daquelas terras.

[...] llegaron cuatro doncellas, la una con una fuente de plata, y la otra con un aguamanil, asimismo de plata, y la otra con dos blanquísimas y riquísimas toallas al hombro, y la cuarta descubiertos los brazos hasta la mitad, y en sus blancas manos (que sin duda eran blancas), una redonda pella de jabón napolitano. ${ }^{42}$

$\mathrm{Na}$ sequência, retornando ao "Coloquio", Cipión concorda com a atitude do amigo Berganza e afirma:"Hiciste muy bien, por ser prerrogativa de la hermosura que siempre se le tenga respeto." (CERVANTES, 2005, p. 656).

É oportuno observar que a afirmação de Cipión remete a concepção metafísica da beleza platônica, embora o protagonista faça uso desse princípio a fim de tecer uma ironia com relação às ações de Berganza diante da beleza da jovem dama. Assim, é importante rever o preceito platônico a esse respeito.

\footnotetext{
${ }^{41}$ LLOSA SANZ, Álvaro. El canon de belleza femenina en tiempos de La Celestina a través de textos de la época. Disponível em: http://pt.scribd.com/doc/943589/El-canon-de-belleza-femenina-en-tiempos-deLa-Celestina-original. Acesso em: 10 jul. 2014.

${ }^{42}$ CERVANTES, Miguel de. Segunda parte del ingenioso cavallero Don Quijote de la Mancha. Brasil: RAE, 2004.
} 
Dessa forma, para o filósofo, a beleza do corpo difere da beleza do espírito, a qual consiste na elevação e no aperfeiçoamento da alma (MANSUR, 2011, pp. 87-8). Para Platão, a contemplação da beleza deste mundo é uma via de ascensão até se chegar à beleza em si, cuja prerrogativa consiste em um aperfeiçoamento moral e intelectual daquele que a contempla. Essa beleza a que Platão faz referência tende a um bem proveniente de um ato de generosidade divina, pois ela desperta nos homens o amor, com a finalidade de chegarem aos princípios inteligíveis e a valores éticos (p. 91). Esse princípio platônico conduz ao amor e à virtude. Com isso, orienta os indivíduos a deixarem de lado o amor às coisas e às pessoas, a fim de alcançarem a beleza das ideias.

No caso da jovem prostituta, cuja referência é feita na novela de forma pejorativa, a ironia está em relacionar sua beleza com a platônica, a qual estriba na vida moral e ética do ser humano. Daí a se perceber que a afirmação de Cipión carrega certa mordacidade ao associar essas virtudes morais à jovem prostituta. $\mathrm{O}$ engano de que Berganza foi vítima teve tal êxito porque o protagonista possivelmente tem $o$ aperfeiçoamento moral e intelectual necessários à contemplação dessa beleza, embora tenha acreditado que esse bem possa habitar em seres que vivem no pecado. Essa deformação moral, encontrada em toda a gente do Matadouro, retorna para os princípios platônicos, cuja afirmação contida em sua obra República reforça o tema abordado por Cipión: "La virtud en consecuencia, será, a lo que parece, la salud, la belleza y el bienestar del alma y el vicio, a su vez, su enfermedad, fealdad y flaqueza.” (p. 91).

Vítima de um ato de vileza, Berganza regressa ao Matadouro com o cesto na boca; no lugar da carne, um chapim velho, fruto da vingança de uma das "amigas" de seu amo. Entretanto, ao perceber a brincadeira maliciosa, Nicolás dirige toda a sua violência contra o pobre cão. 
BERGANZA. [...] volví a mi amo sin la porción y con el chapín. Pareciole que volví presto, vio el chapín, imaginó la burla, sacó uno de cachas y tirome una puñalada que, a no desviarme, nunca tú oyeras ahora este cuento, ni aun otros que pienso contarte. (p. 657)

Com muita sorte, Berganza foge da investida de Nicolás, toma o destino em suas mãos, ou melhor, em suas patas, e deixa para trás o Matadouro e aquela "boa gente".

Com base nos conceitos expostos mediante o diálogo canino, pode-se concluir que a engenhosidade contida na escritura da novela demanda de um pleno domínio das técnicas de construção textual, as quais se utilizam das advertências de Cipión para introduzirem certa temporalidade no interior do texto (REY HAZAS, 1983, p. 131). Assim, através dessa dinâmica, esse perspicaz interlocutor institui uma atitude contrária às digressões, a fim de evitar a perda de unidade, de coerência e até mesmo a perda da própria justificativa da narrativa de Berganza (p. 131).

Nessa configuração, por intermédio de seus comentários, Cipión introduz modelos de discursos filosóficos e exemplares, com um certo tom moral, sem converter a narrativa do "Coloquio" em um discurso moralizante. Por essa razão, o elemento cômico surge inúmeras vezes por meio das intervenções dialogais desse discreto interlocutor, fazendo com que essa relação de mestre e discípulo, análoga à relação de Dom Quixote e Sancho, busque o entretenimento mediante uma escrita engenhosa, que caminha com vistas a suscitar o riso. 
II. A VIDA NO CAMPO - BERGANZA, O CÃO PASTOR 


\section{A aparente pureza do campo, as lembranças da cidade}

Porque cierto es que el verdadero pasto del hombre está dentro del mismo hombre y en los bienes de que es señor cada uno.

Fray Luis de León

Dentre os gêneros narrativos presentes nos séculos XVI e XVII, o gênero pastoril esteve muito em voga nesse período, juntamente com as novelas de cavalaria. Composto por uma mescla de prosa e verso, historias intercaladas, églogas, cartas, esse gênero se caracterizou pela predominância do tema amoroso, tendo como pano de fundo a natureza, que recebe seu protagonista na figura do pastor. A vida desse pastor se situa em um mundo atemporal, sem passado ou presente, em que o espaço é composto por uma paisagem natural, servindo de palco para as juras de amor, lamentações e músicas que compõem o enredo desse gênero bucólico. Entretanto, se instaurou uma censura a essas composições, como se verá mais à frente, tanto de autores humanistas quanto do meio eclesiástico, que culminou em alterações importantes para esse tipo de discurso, produzindo uma novela pastoril voltada ao enaltecimento de princípios cristãos, cujos exemplos serão examinados mais detidamente neste subcapítulo da novela.

O interesse deste trabalho está em observar como tais questões se apresentam no interior do "Coloquio" no instante em que Berganza, diante da violência de seu amo e das ações viciosas daqueles que o rodeiam no Matadouro de Sevilha, foge rumo ao campo.

Certamente, essa fuga do personagem o conduz inesperadamente para a vida bucólica. Quando se depara com a natureza, fica incentivado a acreditar ter encontrado 
seu verdadeiro caminho, seu real objetivo: “[...] amparar y defender de los poderosos y soberbios los humildes y los que poco pueden.” (CERVANTES, 2005, p. 657).

Mais uma vez no "Coloquio", está-se diante de fatos casuais, de feitos que se apresentam alheios à vontade do protagonista, pois na história de sua vida todas as circunstâncias ocorrem de forma surpreendente, nada é intencional, se pensarmos bem, até a própria novela se constitui por um feito incrível, ou seja, um diálogo entre dois cães. Assim, nesse momento da obra o personagem se vê diante de um novo ofício: cão pastor, uma atividade que se caracteriza não só pela guarda de carneiro e ovelhas, mas agora pela missão de proteger os fracos e indefesos.

Entretido em suas reflexões, Berganza é encontrado pelos três pastores responsáveis pela guarda do rebanho, como mostra o fragmento abaixo:

BERGANZA. Apenas me hubo visto uno de tres pastores que el ganado guardaban, cuando, diciendo "To, to", me llamó. Y yo, que otra cosa no deseaba, me llegué a él bajando la cabeza y meneando la cola. Trújome la mano por el lomo, abriome la boca, escupiome en ella, [...] y dijo a otros pastores que yo tenía todas las señales de ser perro de casta.(CERVANTES, 2005, p. 657)

Evidentemente, os pastores receberam Berganza com muita rudeza, embora havia os aspectos relacionados à tradição folclórica dos trabalhadores do campo, no sentido de cuspirem na boca do animal a fim de evitarem o "mau olhado" (CERVANTES, 2005, pp. 657-8). Mesmo assim, fica evidente a rusticidade com que o recebem, contrapondo-se com a atitude de humildade apresentada pelo cão. Esse comparativo é pertinente no sentido de notar com que demonstração de respeito e submissão o jovem mastim aproxima-se dos pastores. Além disso, o personagem sentia contentamento ao se deparar com o rebanho de carneiros e ovelhas, com a vida pastoril, tendo em vista as adversidades passadas na cidade, no interior do Matadouro de Sevilha. 
$\mathrm{Na}$ sequência, suas primeiras impressões sobre os novos amos e o ofício de "perro pastor": "Vime harto y contento con el segundo amo y con el nuevo oficio; mostreme solícito y diligente en la guarda del rebaño [...]”. (CERVANTES, 2005, p. 659).

Retornando as falas iniciais de Berganza, juntamente com o parágrafo acima, pode-se perceber que o protagonista segue princípios teológicos amparados no senso de dever. Isso se justifica porque através desse objetivo o personagem destaca a inclinação do homem em buscar na vida pastoril um consolo para suas adversidades, com a crença de que a natureza cura todos os males, e, nesse caso, conduz à cura dos vícios e de toda a maldade humana. Mesmo porque, até então, Berganza só conhecera um mundo de roubos e violências no Matadouro de Sevilha. Por essa razão, ao se achar no campo o cão acredita estar diante, enfim, de seu verdadeiro lugar no mundo, de sua verdadeira missão.

Nesses termos, fica evidente a tendência do protagonista em relacionar a vida do campo e o ofício de pastor com a missão daquele que guarda e cuida das almas humanas contra os males do mundo. Ademais, diante do cenário bucólico, Berganza se vê impulsionado a vislumbrá-lo como o espaço onde poderá reencontrar a virtude perdida, um lugar que o direciona a atitudes mais voltadas a valores cristãos. É importante perceber que a alegoria cristã retratada nesse episódio do "Coloquio" apresenta a vida pastoril sob uma perspectiva teológica, acreditando na existência de um Pastor, responsável por um rebanho, no caso a humanidade. Essa metáfora cristã associada ao campo proporciona ao homem um desenvolvimento de suas qualidades morais, contidas na simplicidade e na inocência, atributos apartados dos vícios e do artificialismo das cidades.

Entretanto, é interessante notar como esse preceito teológico se presentifica, também, em outras produções do período contido entre os séculos XVI e XVII, cujo 
tema parte do universo pastoril, e em seguida é direcionado a uma tópica de caráter religioso. Com base nessa característica, Avalle-Arce recorda que no século XVI as novelas pastoris, apesar de sua aceitação e do papel hegemônico do pastor como personagem tipo (AVALLE-ARCE, 1974, pp. 13-4), passaram a ser percebidas tanto pelos humanistas, levando-se em conta que os erasmistas aceitavam a "utopia do gênero", quanto pelos religiosos, como obras que continham um discurso inverossímil, pois se afastavam dos conceitos de verossimilhança por não retratarem uma verdade possível. Nesse sentido, alguns autores do Século de Ouro, como é o caso de Lope de Vega e Quevedo (AVALLE-ARCE, 1974, p. 267), cujas obras La más prudente venganza, La Dorotea e El buscón disparam suas "farpas" contra a novela pastoril, alegando a diferença existente entre o mundo ali retratado e a imitação de modelos artísticos, conforme os respectivos fragmentos:

Ya se llegaba la hora de comer y ponían las mesas, para que sepa vuestra merced que no es esta novela libro de pastores, sino que han de comer y cenar todas las veces que se ofreciere ocasión. (La más prudente venganza, 2007, p. 4)

Porque esto de pastores todos es arroyuelos y márgenes, y siempre cantan ellos o sus pastoras. Deseo ver en un día un pastor que esté en un banco y no siempre en una pena o junto a una fuente. (La Dorotea, 1913, p. 95)

Ítem, advirtiendo que después que dejaron de ser moros, aunque todavía conservan algunas reliquias se han metido a pastores, por lo cual andan los ganados flacos de beber sus lágrimas, chamuscados con sus ánimas encendidas, y tan embebecidos en su música que no pacen, mandamos que dejen el tal oficio, señalando ermitas a los amigos de soledad. Y a los demás, por ser oficio alegre y de pullas, que se acomoden en mozos de mulas. (El buscón, pp. 35-6) 
No entanto, com dimensões e consequências muito mais graves, a censura religiosa - em função da retomada dos valores cristãos, da reabilitação dos preceitos espirituais e morais presentes nos modelos da contrarreforma pautados pela consolidação da fé e pela disciplina eclesiástica - atrela o gênero pastoril ao texto profano. (AVALLE-ARCE, 1974, pp. 268-9). Em consequência disso, haverá a necessidade de se estabelecer um realinhamento dessa escritura, contemplando essa recuperação da doutrina cristã assumida pela Igreja católica, com vistas a introduzir uma reabilitação desse discurso, convertendo-o em texto religioso. (AVALLE-ARCE, 1974, p. 269). Para Avalle-Arce, esse procedimento se abre para a volta ao divino ou à divinização dessa composição tida como profana, substituindo essa escrita, vista como herética, por algo sublime, sagrado.

Nesse momento, surge a presença de Cristo como pastor e protetor desse rebanho humano, em substituição à figura do pastor - uma alegoria presente nos textos bíblicos, que agora será introduzida ao gênero pastoril; uma visão voltada para um modelo religioso, cujo o caráter ascético servirá de base para a composição de algumas obras do período renascentista. Essas obras irão abordar o tema da antiga oposição entre corte e campo, ou seja, o meio urbano com seus deleites e tentações, contrapondo-se com as virtudes do campo associadas ao ofício de pastor. É o caso dos escritos de Fray Luis de León, De los nombres de Cristo; de Fray Antonio de Guevara, Menosprecio de corte y alabanza de aldea; e de Antonio de Torquemada, Colloquios satíricos, cujas narrativas retratam o campo como o espaço onde se encerra a virtude contida no ofício do pastor, um pastor que se aproxima da imagem bíblica do protetor de almas.

Sendo assim, ao observar a missão de Berganza com respeito à vida no campo e seu ofício de cão pastor, fica evidente o alinhamento da conduta do personagem, nesse instante da novela, com as obras acima citadas. Por intermédio da visão que associa a 
vida pastoril à simplicidade e ao sossego do campo, o papel preponderante da natureza está em despertar no homem afetos bons e puros. Assim, em função de todo esse cenário bucólico, o homem afasta-se por completo da vida viciosa que a corte oferece, como o faz Berganza, quando se aparta dos crimes do Matadouro recorrendo à pureza do campo.

Nesse aspecto, a título de comparação, devem ser revistos os princípios contidos no seguinte fragmento pertencente aos Colloquios satíricos de Antonio de Torquemada, na passagem em que o pastor Amintas enaltece a simplicidade da vida pastoril para os personagens Leandro e Florián:

[...] Todo esto he dicho para mostraros que, siendo la vida pastoril, por muchas causas y razones que para ello ay, más allegada a la que la naturaleza quiso como por principal intento y voluntad que los hombres siguiésemos, que os parezca también que los que la siguen y se contentan con ella no solamente no hacen yerro ninguno, pero que no por eso es razón que sean tenidos en menos que los otros hombres que siguen y andan embebidos cebándose en las riquezas y en los deleites, en las pompas y honras, que todas son vanidades del mundo. (Torquemada, 1994, pp. 301-2)

Como é possível notar, esse tipo de colóquio renascentista em geral sempre introduz uma moral, uma lição a ser seguida, exibindo uma escrita paradigmática. Recupera determinadas tópicas que tratam de enaltecer a vida pastoril, levando em conta a inocência do campo, a pureza e a perfeição das coisas próximas da natureza, contrapondo-se com a vida de tentações das cidades. Seguindo nessa linha de raciocínio, observa-se que o campo retrata o lugar onde o homem pode aproximar-se da natureza, da virtude e, consequentemente, de Deus. Essa tópica traz à memória algumas passagens da Bíblia, cujo tema aborda a figura de Deus como pastor dos homens. Assim, é oportuno rever três das mais conhecidas passagens, do Velho e do Novo 
Testamento, pois acredita-se que serviram de modelo aos textos renascentistas já citados (LE GOFF, 1997), a começar pelos Salmos:

O Senhor é meu pastor, nada me faltará. Deitar-me faz em verdes pastos $[\ldots](\mathrm{S} 122,1)$

Salvai, Senhor, vosso povo e abençoai a vossa herança; sede seu pastor, levai-o nos braços eternamente. (S1 27,9)

Ora, o Deus de paz, que pelo sangue do pacto eterno tornou a trazer dentre os mortos a nosso Senhor Jesus, grande pastor das ovelhas. (Hb $13,20)$.

A autoridade dessa doutrina cristã é sentida em Berganza, pois, além de valorizar a vida no campo, estabelece uma relação desta com o direcionamento moral e religioso proposto em sua missão de defender os humildes e os que pouco podem.

Além disso, a visão do personagem, nesse episódio da novela, aproxima-se do discurso ascético do escritor quinhentista Fray Luis de León, e de sua obra já citada, De los nombres de Cristo, cujo conceito a respeito do campo e da figura do pastor remete ao espaço da simplicidade, longe dos pecados e deleites da cidade. Em sua fala o pastor, mesmo com toda a sua rusticidade, converte-se em representante do amor cristão, que a vida bucólica e sua solidão oferecem (LEÓN, 1956, p. 128).

Nesse sentido, de acordo com os estudos modernos de Avalle-Arce (1974, p. 50), ao referir-se a esses preceitos religiosos contidos em tais obras renascentistas, o pesquisador observa como essas diretrizes se integram ao gênero pastoril, introduzindo elementos em contraposição, contidos na temática campo versus cidade. Esse tema irá propor a descrição da vida na corte, com suas falhas e enganos se opondo à simplicidade do campo, com um propósito moralizante. Todas essas questões são colocadas com a intenção de apresentar um desprezo pelo cotidiano da corte, bem como o 
engrandecimento do campo ou, como diria o pesquisador, uma dualidade que tem por finalidade apresentar um discurso antitético com fins morais, os quais regem toda a estrutura dessas obras em linhas gerais. (p.51)

Retornando ao episódio da novela, após ter sido examinado pelos pastores, Berganza se vê diante do dono do rebanho, que os indaga a respeito da procedência do cão e os orienta no sentido de estabelecerem um elo de carinho entre o novo cão pastor e o rebanho:

BERGANZA. [...] ponle luego el collar de Leoncillo, el perro que se murió, y denle la ración que a los demás, y acaríciale, porque tome cariño al hato y se quede en él. [...] el pastor me puso luego al cuello unas carlancas llenas de puntas de acero [...] Y asimismo me puso nombre, y me llamó Barcino. (CERVANTES, 2005, p. 658)

De acordo com a passagem acima, observa-se a diferença de tratamento dispensado entre os pastores para com Berganza, presente no parágrafo anterior, e as ordens dadas pelo senhor do rebanho, com respeito ao tratamento que os pastores deveriam dispensar ao protagonista. $\mathrm{O}$ interesse do dono do rebanho estava em treinar o cão, não somente para a guarda dos animais, como também de nutrir em Berganza um profundo cuidado para com os carneiros e ovelhas, uma ação terna e elevada que, em sua concepção, tornaria o cão pastor mais diligente em suas funções. Essa presteza de Berganza será responsável pelo desfecho do episódio que irá assolar sua vida de cão pastor, como se verá mais adiante.

Assim, mediante o ofício de cão pastor Berganza retoma seu senso de dever, no instante em que se mostra "solícito y diligente en la guardia del rebaño", pois esse caminho sofrera, em sua concepção, certo desvio em função das ações maliciosas da "jifera dama" de seu antigo amo. Ao reaver a virtude perdida, surge na vida do 
protagonista certo contentamento - os reflexos dessa felicidade se vêm representados na descrição do espaço bucólico que o rodeia:

BERGANZA. [...] las siestas, que me iba a pasarlas, o ya a la sombra de algún árbol, o de un ribazo o peña, o a la de alguna mata, a la margen de algún arroyo de los muchos que por allí corrían. (CERVANTES, 2005, p. 658)

Esse tipo de descrição feita por Berganza, com relação ao campo, se faz presente nas obras renascentistas voltadas à novela pastoril, ora utilizando-se de preceitos cristãos, ora como representantes do próprio gênero, sem qualquer transformação religiosa, como é o caso da Arcadia de Sannazaro, La Diana de Jorge de Montemayor, La Galatea de Cervantes, entre outras. No caso do "Coloquio", a questão se baseia em como esses elementos da natureza encontram certa conformidade, tanto na forma como são expostos quanto com relação à matéria dessa exposição. Por esse motivo, é útil rever esses detalhes en Fray Luiz de León, De los nombres de Cristo, quando, ao falar da vida do pastor, o autor faz uma descrição da natureza como o espaço que o serve e deleita:

[...] de la vista del cielo libre, de la pureza del ayre, de la figura del campo, del verdor de las yerbas, y la belleza de las rosas y de las flores. Las aves con su canto y las aguas con su frescura le deleytan y sirven. (LEÓN, 1945, p. 63)

Nesse sentido, através dessa perfeição da natureza, torna-se evidente a existência de uma comunhão, de um elo entre o ofício de pastor, com sua condição moral perante a vida. Quanto mais distante dos erros e prazeres da cidade ele estiver, quanto mais inocentes forem sua vida e negócios, quanto mais próxima da natureza for sua posição, maiores serão seus deleites, os quais, segundo Fray Luiz de León, são provenientes das coisas simples, puras e naturais que compõem o cotidiano desse pastor, uma existência 
sem desvios, afastada das tentações da cidade, onde o amor tem pouco de verdade e muito de astúcia (LEÓN, 1945, p. 126).

Entretanto, para Berganza as lembranças da cidade não deixavam sua mente ociosa, pois ele recordava da vida que levara no Matadouro de Sevilha. Ao trazer à memória essas recordações, a postura do protagonista sofre algumas alterações, pois a simples recordação do cotidiano da cidade desperta em Berganza uma censura tanto referente às práticas quanto ao caráter dos frequentadores do Matadouro, conforme o parágrafo a seguir:

BERGANZA. [...] ocupaba la memoria en acordarme de muchas cosas, especialmente en la vida que había tenido en el Matadero, y en la que tenía mi amo y todos los como él, que están sujetos a cumplir los gustos impertinentes de sus amigas.; Oh, qué de cosas te pudiera decir ahora de las que aprendí en la escuela de aquella jifera dama de mi amo! (CERVANTES, 2005, p. 659)

Nesse fragmento da novela, lançando um olhar mais atento para os aspectos que norteiam a memória de Berganza, todos os acontecimentos relacionados às suas incursões no Matadouro de Sevilha, bem como aqueles provenientes de seu contato com a jovem dama de Nicolás, trazem para o protagonista imagens mnemônicas que se convertem, como diria em seus estudos recentes Gustavo Illades, "em semelhanças corporais, ou formas tangíveis e, por isso, substituem materialmente as intenções morais" (ILLADES, 2007, p. 266). Essas lembranças do Matadouro trazem a Berganza uma série de imagens, cuja matéria estabelece a similaridade de ações e de coisas, com seus culpados, tornando todos os acontecimentos mais marcantes, seja por sua verossimilhança, pois pertencem ao passado recente de Berganza, um fato real e verdadeiro dentro da ficção, seja por sua fealdade. 
No entanto, as recordações do personagem não passam de coisas vividas em "la escuela de aquella jifera dama", que, se naquele momento foram amargas e perversas, agora irão compor uma fala maliciosa, que tende a comicidade.

Nesses termos, voltando ao fragmento acima, essa pequena reflexão com respeito à jovem dama faz com que o personagem, cujas intenções por ocasião de sua chegada ao campo apontavam para procedimentos contidos no resgate de uma virtude cristã, agora assuma uma postura censora, uma fala tendenciosa, voltada ao vitupério, fazendo com que o discurso expresse, em alguns momentos, certas características equívocas, com tendências maledicentes.

De modo a sustentar tal asserção, verifica-se no fragmento nova utilização do adjetivo "jifera", e de que maneira o termo transforma as falas do personagem em um discurso que se destaca por apresentar dois sentidos ao mesmo tempo válidos. A princípio, o adjetivo é atribuído à jovem em função de sua relação com Nicolás, um "jifero", como raciocínio conclusivo sua amiga/namorada é vista como uma "jifera". Entretanto, como é sabido, a jovem era uma prostituta e daí se pode inferir que o adjetivo estabelece uma analogia à profissão da jovem, bem como às suas práticas, ou seja, lidar com a carne, cujo termo em posição metonímica significa: lidar com os homens. Essa expressão maledicente, se por um lado denigre a personagem, transformando-a em objeto de ataque em consequência de seus erros e artimanhas, por outro a converte em matéria de riso, pois Berganza, ironicamente, intitula o universo do Matadouro de Sevilha como: "la escuela de aquella jifera dama de mi amo", isto é, o lugar onde se aprendem todas as piores lições da vida, da prostituição ao roubo, do roubo ao crime de morte.

De fato, a partir dessas recordações, Berganza assume um olhar mais severo com relação às suas atividades anteriores no Matadouro, comparadas com seu ofício atual de 
"perro pastor". Essa comparação campo-cidade fará com que o protagonista introduza uma censura, tendo como alvo os personagens pretéritos, cuja lembrança acarreta uma quebra no tom desse discurso, tornando-o mordaz.

Assim, o escárnio e a indignação do protagonista crescem na proporção que aumenta o ensejo em refrear seus instintos. Na realidade, o propósito de Berganza está em evitar que a perspectiva religiosa, inicialmente contida em sua narrativa, se converta em um texto profano, sem qualquer fim ético, ou seja, um discurso que se afaste dos valores e princípios morais necessários para a boa conduta do homem. Com efeito, se as intenções de Berganza inicialmente se pautavam pela proteção dos humildes e dos que pouco podem, introduzidas através de um afeto que emergiu no protagonista ao se deparar com a vida bucólica e o ofício de cão pastor, agora suas lembranças trazem à tona não somente as faltas do antigo amo e de sua "jifera dama", mas também despertam em Berganza um ímpeto que o instiga a assumir uma postura contrária ao proposto anteriormente.

Portanto, nesse episódio da novela, pode-se verificar uma série de modelos de representação, a começar pelo gênero pastoril, utilizado pelo autor com o propósito de introduzir um princípio cristão pautado na valorização da vida bucólica, contrapondo-se aos vícios da cidade. Seria uma espécie de refúgio encontrado por Berganza, com o intuito de escapar dos males que o afligiam no Matadouro de Sevilha. Entretanto, essa aparente pureza do campo começa a ser ameaçada pelas lembranças do protagonista, as quais irão transformar essa suposta tranquilidade e perfeição em um mundo de dúvidas e incertezas, que o conduzem a questionar a maneira com que deve apresentar sua própria história.

Na realidade, Berganza está diante de um embate entre um discurso que tende a assumir uma postura religiosa e indulgente e uma censura mordaz amenizada pela sua 
aparente ingenuidade. Por isso, essa contenda se converte em algo cômico, pois se por um lado o protagonista tenta ferir e atacar seu destinatário, mesmo que seja de forma duvidosa, por outro, devido sua aparente pureza, avalizada pela orbe pastoril, acaba assumindo formas mais benevolentes. Isso traz à memória os estudos de Antonio Ríos Rojas ao citar a afirmação de Américo Castro com respeito à fala cervantina apresentar dois sentidos:

Lo frecuente es que tales ideas bogasen libremente por el campo de la literatura, protegidas por fórmulas ambiguas de lenguaje, en apariencia ortodoxas, o a favor del flexible recurso de la doble verdad. (RÍOS ROJAS, 2006, p. 3) 


\section{O riso a serviço da sátira, da prédica e da murmuração}

Haced todo sin murmuraciones y contiendas.

Fp 2,14

Diversas composições escritas nos séculos XVI e XVII na Espanha foram marcadas por um discurso cômico, cuja finalidade estava em retratar e censurar vícios, costumes e fraquezas da sociedade do período, como é o caso da novela exemplar "El coloquio de los perros". Mediante um diálogo narrativo que tende ao filosófico, as personagens caninas descrevem um quadro decadente da condição humana, com uma fala que transita entre a ingenuidade e a mordacidade. Assim, o "Coloquio" vai entretendo seus leitores à medida que institui uma censura moral.

Ademais, cabe ressaltar que esse diálogo canino adquire sua maior expressão à medida que certos temas e personagens são apresentados pelos protagonistas. Um exemplo disso é o tema da murmuração ou da "fala entre dentes" que sempre está entre os mais discutidos pelos protagonistas da novela. Com questões que destacam seu emprego indiscriminado, sua finalidade e uso, a murmuração acaba sendo transformada em um dos motivos centrais dessa novela exemplar. Assim, o presente subcapítulo tem como objetivo analisar essa prática discursiva e sua relação de equivalência com o sermão e a sátira.

Essas questões começam a se destacar no "Coloquio" a partir das lembranças que Berganza tem do Matadouro de Sevilha, de Nicolás e das coisas que lhe ensinaram naquela "escola". No entanto, o protagonista refreia seu discurso e justifica: “(...)Pero habrelas de callar, porque no me tengas por largo y murmurador." (CERVANTES, 2005, p. 659) 
O que se verifica nesse momento da novela é a preocupação do jovem mastim com relação ao próprio ato de narrar, pautado pelo cuidado em não apresentar um discurso extenso, repleto de maledicências e impropriedades, propenso a se converter em uma narrativa difamatória. No entanto, é oportuno indagar: pode-se evitar a murmuração? No caso de ser inevitável, quais seriam seus limites? Esse tipo de discurso estaria restrito a um certo grupo de pessoas, no caso o vulgo, ou se estenderia à fala de indivíduos pertencentes a outros estamentos sociais?

Para responder a essas perguntas, começo recorrendo a um exemplo mais explícito, encontrado em Dom Quixote, Parte II, na curiosa cena que retrata o diálogo entre Sancho Pança e sua esposa Teresa. Nessa passagem, Sancho informa à mulher de seu retorno ao ofício de escudeiro e, consequentemente, aos serviços para com o "lendário cavaleiro andante". Dessa forma, cavaleiro e escudeiro se veem diante da terceira saída e, de certo modo, de uma oportunidade para Sancho de realizar seu desejo de tornar-se governador de uma ilha, sem contar com os planos relacionados à família, em especial de transformar Sanchica, sua filha, em condessa. Diante dos projetos do escudeiro, bem como das ações do personagem direcionadas a conseguir um título de nobreza para a filha, Teresa se mostra contrária aos sonhos do marido, e justifica esse descontentamento no parágrafo a seguir:

- ¿Sabéis por qué, marido? - respondió Teresa. - Por el refrán que dice: "Quien te cubre, te descubre". Por el pobre todos pasan los ojos como de corrida, y en el rico los detienen; y si el tal rico fue un tiempo pobre, allí es el murmurar y el maldecir, y el peor perseverar de los maldicientes, que los hay por esas calles a montones, como enjambres de abejas. (CERVANTES, 2004, p. 586)

De acordo com a opinião de Teresa, a murmuração e "el maldecir" são termos sinônimos, pois falar mal de alguém significa murmurar. Essa prática, encontrada nas 
ruas, frequentemente na fala do vulgo, é algo, segundo Teresa, que persevera em função de ser seguida por grande quantidade de pessoas, que se assemelham a um enxame de abelhas. Conforme a afirmação de Teresa, pode-se pensar que essas pessoas, por serem rudes, simples, sem qualquer refinamento, empregam esse hábito discursivo nas conversas do dia a dia. Afinal, o vulgo sempre está em maior número e se vê impulsionado a denegrir aqueles que lhes sobrepõem, ora pelo lugar que ocupam dentro da hierarquia social, ora pela cultura adquirida. Enfim, quando se sentem coagidos ou humilhados, seja qual for o motivo, se convertem em murmuradores por excelência.

Porém, a questão é mais complexa, pois esse discurso não se limita apenas à plebe, mas se estende por todos os estamentos sociais: dos homens de letras aos vinculados à Igreja, todos, sem exceção, praticam a murmuração. Nesse sentido, ao observar o artigo de Gustavo Illades ${ }^{43}$, "Sátira, prédica y murmuración: genealogía de una contienda por la voz en el Quijote de 1605 ", vê-se que o pesquisador acredita que essa fala se aproxima do discurso satírico, próprio daqueles que querem tecer uma censura, seja ela moral ou religiosa, com o fim de repreenderem o objeto de ataque, mas sem destruí-lo por completo. Entretanto, a murmuração se encontra no limiar da questão, isto é, tanto pode ser amena e leve quanto feroz e amarga, causando certo "sangramento" em suas vítimas. Daí a necessidade de se utilizar essa forma discursiva de maneira plausível.

Paralelamente, em seu livro A sátira e o engenho, no capítulo que trata sobre a "Murmuração do corpo místico", João A. Hansen afirma, ao analisar as Atas da Câmara e as Cartas do Senado da cidade do Salvador, Bahia de Todos os Santos do Estado do

\footnotetext{
${ }^{43}$ ILLADES, Gustavo. "Sátira, prédica y murmuración: genealogía de una contienda por la voz en el Quijote de 1605”. Disponível em: http://www.h-net.org/ cervantes/csa/artics07/illadess07.pdf. Acesso em: fev. 2010. p. 162.
} 
Brasil $^{44}$, que a murmuração está incluída na "unificação hierárquica" que consiste "na vontade unificada de todos na subordinação ao rei”(p. 123). No entanto, essa murmuração questiona essa unificação hierárquica, para "solvê-la e repropô-la como hierarquia", até mesmo porque, como evento, a murmuração deve ser evitada, pois é um “[...] movimento observável na sátira, que murmura contra a murmuração ou que corrige a hierarquia que permite a murmuração.” (p. 123).

Para o pesquisador, a murmuração excessiva da plebe não deixa de apresentar um perigo para a manutenção do poder, apesar de que pode se constituir "como honra, justiça daqueles que aplicam o poder sobre a população"(p. 124). Lembrando que honra, reputação e reverência possuem quase o mesmo sentido no século XVII, pois direcionadas politicamente têm a função de opinião, ou seja, são conferidas ao seu destinatário como forma de consideração pública. Por essa razão, a honra é atribuída pela opinião alheia, devendo ser mantida a "todo custo como moral da aparência e aparência da moral” (p. 136). Conservar a honra, manter as aparências em qualquer situação implicava não ter a reputação abalada e, consequentemente, não perder a autoridade, a obediência. Para Hansen,

[...] tem honra quem pode tirá-la de outro e assim, paradoxalmente, os grandes se mantêm em evidência e recebem a fama e a glória devidas à sua posição por parte daqueles que institucionalmente não a têm, o vulgo, mas que pode tirá-la pela murmuração. (HANSEN, 2004, p. 137)

Nesse sentido, para o estudioso, quando a murmuração "ultrapassa os limites [...], transforma-se em sedição e é crime de traição". Além disso, "a murmuração é o

\footnotetext{
${ }^{44}$ Cabe observar que essas práticas de representação eram verificadas em várias situações discursivas presentes não somente na corte luso-brasileira, mas também nas italianas e espanholas do século XVII. Segundo Hansen, "nos discursos feitos no Brasil, por exemplo, os temas das instituições locais e da murmuração informal, que preenchem e particularizam os mesmos esquemas retóricos-poéticos generalizados como modelos de todas as práticas discursivas.” Disponível em: http://revistas.usp. br/discurso/article/view/37998 Acesso em: 12 abr. 2012.
} 
acontecimento transgressor de normas vigentes que, muitas vezes, se identifica com a mesma murmuração" (p. 138).

Retornando ao "Coloquio", Berganza expressa uma série de censuras contrárias às práticas tanto de seu antigo amo quanto de sua "jifera dama", e para isso faz uso da murmuração. No entanto, ao perceber a inconveniência de suas afirmações e a possível posição de murmurador, questiona o próprio discurso a fim de que não seja denegrido pela murmuração.

Na sequência, deve-se verificar a opinião de Cipión diante das preocupações de Berganza e de sua provável posição de murmurador: "Por haber oído decir que dijo un gran poeta de los antiguos que era difícil cosa el no escribir sátiras, consentiré que murmures un poco de luz y no de sangre [...].” (CERVANTES, 2005 p. 659).

Para Cipión, a murmuração deve ter uma certa moderação, um freio que impossibilita a construção de um discurso difamatório, cujas palavras venham a ferir o destinatário, ocasionando sua destruição. Por esse motivo, o cão estabelece uma relação entre a dificuldade de se evitar a sátira, referindo-se à afirmação de um poeta dos antigos, no caso Juvenal ${ }^{45}$ (JUVENAL; PÉRSIO, 2008, pp. 81-2), e com isso introduz o consentimento de que haja uma murmuração, cujo resultado lance à narrativa um pouco de luz e não de sangue. Em outras palavras, uma ação controlada, voltada para a repreensão dos vícios, mas afastando-se por completo da detração. Seguindo esse preceito contido na fala de Cipión, Illades define a murmuração na obra cervantina:

[...] la originalidad en Cervantes consiste en autorizar en el Génesis bíblico el derecho a la palabra como derecho a murmurar, con el argumento implícito de que la maledicencia no es obra del demonio,

\footnotetext{
${ }^{45}$ JUVENAL. PERSIO. Sátiras. Madrid: Ed. Gredos, 2008. pp. 81-2.

Cabe citar um trecho da Sátira I de Juvenal. "Cuando un miembro de la chusma del Nilo, un esclavo nacido en Canopo, este Crispino, se quita del hombro una capa tiria y refresca en sus dedos sudorosos un anillo de invierno, pero aquí, estando en pleno verano. Todo para acentuar su personalidad ostentosa, o sea, es difícil no escribir una sátira."
} 
sino expresión de la naturaleza humana. Pero la acción natural de murmurar sólo transmite conocimiento si posee la intención ética de dar luz sin derramar sangre. (ILLADES, 2008, p. 170)

Revendo os estudos sobre a sátira de costumes nos diálogos renascentistas espanhóis feitos por Lina R. Cacho (RALLO GRUS, 2006, pp. 142-3), a pesquisadora demonstra que muitos dos colóquios quinhentistas associaram a sátira à maledicência, esta caracterizada pela rudeza e aspereza contidas em suas manifestações. A título de exemplo, a autora menciona Antonio de Guevara e o Prólogo de sua obra Menosprecio de corte y alabanza de aldea, no trecho em que o autor afirma: "[...] no contento de reprehender a los cortesanos quando predico, me prescio de ser también satírico y áspero en los libros que compongo [...]". Nesse sentido, coube à pesquisadora verificar, no discurso de Guevara, que o direito de fazer sátiras é de quem foi pecador por excelência, pois conhece por experiência o vício que censura. Nessa linha de raciocínio, a título de exemplo, a estudiosa introduz os comentários das personagens Matalascallando e Pedro de Viaje de Turquía de Cristóbal de Villalón, extraído do capítulo intitulado "El viaje por Italia":

MATALASCALLANDO: [...] Por eso me quieren todos mal, porque digo las verdades; estamos en una era que en diciendo uno una cosa bien dicha o una verdad, luego le dicen que es satírico, que es maldiciente, que es mal cristiano $[\ldots]$

PEDRO: ¿Qué malo, qué maldecir, qué perjuicio de partes veis aquí? Lo que yo decía el otro día: maldecir llamáis decir las verdades y el bien de la República; si eso es maldecir, yo digo que soy el más maldiciente hombre del mundo. (p. 143)

Assim, a diferença encontrada entre a sátira e o maldizer (p. 143) consiste em que a primeira ataca os vícios de uma maneira geral, enquanto que este ataca o tipo vicioso, nem sempre introduzindo um discurso vinculado à verdade. Daí a se perceber 
que a sátira ou a fala verdadeira é introduzida nos discursos como correção das falhas humanas.

É importante notar que a sátira em Cervantes, segundo os estudos de Anthony Close (1990, pp. 496-7), se aproxima mais do estilo da sátira horaciana, em função de sua amenidade e tato, pois trata de temas relacionados à correção de qualquer deformidade moral. Para o pesquisador, Cervantes observava o mundo social e político que o rodeava de maneira inteligente, até chegava a ter opiniões censoras a seu respeito, embora negava-se a expressar essas opiniões abertamente, exceto quando esse juízo tivesse possibilidades mínimas de ferir sensibilidades. (p. 497)

Essa preocupação latente no autor do "Coloquio" tem como objetivo, além de preservar certa dignidade ao destinatário da repreensão, evitar a sátira escarnecedora. Essa característica torna-se uma constante em toda a novela, pois se, por um lado, através de suas reminiscências, Berganza emite uma opinião mordaz a respeito das questões em jogo, por outro lado Cipión terá o papel de mediador desse relato, como se leu páginas atrás, no momento em que apresenta alternativas mais comedidas e introduz um "freio" nessa impetuosa narrativa de Berganza. Cabe observar a continuação de sua fala:

CIPIÓN. [...] quiero decir que señales y no hieras, ni des mate a ninguno en cosa señalada; que no es buena la murmuración, aunque haga reír a muchos, si mata a uno; y si puedes agradar sin ella, te tendré por muy discreto. (CERVANTES, 2005, p. 659)

O direcionamento à moderação, à justa medida com respeito ao ato de narrar, torna-se evidente nesse fragmento. Nesse aspecto, se o discurso tende ao comedimento, cuja prática remete a um autocontrole, uma adequação, tanto do tema desse discurso quanto com relação àqueles a quem ele se destina, o emprego dessas ações será 
responsável por estabelecer o caráter de seu enunciador, que na opinião de Cipión deve ser um homem discreto.

Nessa configuração, para se compreender o papel do discreto nas sociedades de corte, bem como na fala de Cipión, uma vez que o tipo discreto é muito mencionado ao longo do colóquio canino, é importante verificar essas questões referentes à discrição no período compreendido entre os séculos XVI e XVII. Em seus estudos com respeito à prática da discrição instituída pelo personagem Cipión na novela "El coloquio de los perros”, Maria Augusta da Costa Vieira (2011, pp. 101-2) estabelece um paralelo entre as investidas do personagem canino, com relação ao uso da linguagem adotada por Berganza, e uma das tantas advertências que Dom Quixote faz a Sancho sobre as formas de se utilizar a fala no convívio social, isto é, da necessidade de se fazer uso de uma linguagem pura, própria e elegante, que interaja com determinadas práticas, próprias da sociedade de corte e presentes no comportamento do homem tido como discreto. Para a pesquisadora, a discrição não é somente

[...] una cualidad que se evidencia esencialmente en la vida social, no se relaciona directamente con la clase social a la que pertenece uno, [...] sino que depende de las habilidades personales, de la inteligencia y de una cierta autoeducación y, de ese modo, puede ser tan discreto un hombre simple como un cortesano. (VIEIRA, 2011, p. 102)

Com base nessa afirmação, ao lançar um olhar mais atento ao tipo intelectual do discreto, pode-se notar que, evidentemente, a condição de cortesão não o habilita para ser um discreto, mas sim por apresentar um comportamento prudente, moralmente adequado, pois suas práticas são pautadas pelo decoro. Em outros termos, o discreto sabe condicionar suas ações e palavras à ocasião, à recepção, bem como à conveniência dessa representação. Nesse sentido, o discreto acomoda fala e gestos, sempre apresentando um autocontrole, agindo como é preciso e como é devido. Para Maria 
Augusta da Costa Vieira, o discreto "[...] socialmente codifica las virtudes del cortesano y del perfecto caballero cristiano, distinguiéndose de los demás destinatarios por el discernimiento, el ingenio y la prudencia [...]" (VIEIRA, 2011, p. 107).

Assim, o discreto se pauta pela moderação de suas atitudes, por um pensar racional baseado na dignidade moral. Para Hansen o discreto é:

uma categoria intelectual que classifica ou especifica a distinção e a superioridade de ações e palavras; [...] o termo discreto significa a qualidade intelectual de penetração nos assuntos, como perspicuidade ou perspicácia, por isso relaciona-se ao talento intelectual da invenção, o engenho retórico, e à capacidade lógica e analítica da avaliação, o juízo dialético. (HANSEN, 1996, pp. 83-4)

Por todas essas classificações, pode-se supor que Cipión represente, em muitas ocasiões no "Coloquio", a alegoria do discreto, seja pelo discernimento observado em suas falas, seja pelo comedimento introduzido em suas ações. Por outro lado, Berganza denuncia, por meio de suas reminiscências, as práticas de um mundo corrompido pela falta de moral, envolto mais em vícios do que em virtudes, retratado por intermédio de uma narrativa que transita entre a sátira e a murmuração concomitantemente.

O que conduz a observar que no texto da novela, segundo Riley, o sentido de "murmurar y satirizar son equivalentes" em Cervantes, e no caso do "Coloquio" essa murmuração parece ser quase "inextirpable del carácter humano" (RILEY, 1988, pp. 86-93).

A originalidade cervantina está em abordar questões que se aproximam ora de um discurso doutrinal, ora de formas discursivas próprias do gênero cômico, através do colóquio canino. No entanto, quando Berganza direciona seu discurso a uma fala maledicente, tendenciosa, Cipión o interrompe, com certo didatismo, recuperando o comedimento e a discrição do diálogo. 
Assim, introduzida nessa narrativa como expressão da natureza humana, a murmuração é, como diria Antonio Ríos Rojas ao comentar os diversos aspectos desse colóquio canino, um saber murmurador que vai além da própria murmuração, “y a través de ella y de los pasos atrás que la prudencia hace dar al murmurador, muestra toda una honda crítica a respecto de la realidad social" (RÍOS ROJAS, 2006, p. 6). Desse modo, o cuidado com a linguagem percebido nas falas de Cipión, no sentido de evitar a murmuração, torna-se apenas intencional, porque para o pesquisador, tal como afirma Riley, a murmuração é inevitável a partir dos feitos humanos. (2006, p. 6)

Entretanto, como trazer à tona os abusos sociais, os males sem protestar, condená-los ou apontá-los sem ferir seu alvo, murmurando "un poco de luz y no de sangre"? Para Riley, a resposta está na própria escritura da novela, ou seja, “con las acciones, no con las palabras; con hacer, no con hablar; con el ejemplo, no con el sermón” (1988, p. 93).

Nessa configuração, no momento em que esse diálogo canino busca, mediante feitos humanos, exemplificar os pecados dessa "buena gente", tal fala assume características mais indulgentes, com tendências a ridicularizar esse objeto de ataque, transformando-o em matéria de riso. Observa-se, ainda, que a sátira como subgênero do cômico também pode conter elementos que a aproximam do ridículo, do feio, no instante em que essa censura moral introduz um estilo mais lúdico.

De acordo com Ignacio Arellano (2006, pp. 337-8) em sua obra Las máscaras de Demócrito: en torno de la risa en el Siglo de Oro, todas as poéticas desse período afirmam que a sátira tem como finalidade a correção das falhas humanas mediante uma censura moral. Às vezes apropria-se do burlesco, com o intuito de reduzir a mordacidade desse ataque satírico. 
Nesse aspecto, pode-se dizer que o riso satírico, segundo o estudioso, se caracteriza por sua intenção de censurar moralmente e por sua dimensão ética. Apesar de o riso cômico manter as mesmas características, geralmente aparece ligado ao burlesco, pois trata as coisas de maneira jocosa e graciosa. Mesmo com sua aparente amabilidade e moderação, esse riso não deixa de apresentar certa carga de agressividade, que pode ser introduzida ora pela censura, por meio de uma postura mais violenta, ora por discursos capazes de tornar branda a agressão desse ataque (ARELLANO, 2006, pp. 340-7).

Para Arellano, no interior de um texto, a diferença entre o riso satírico e o riso cômico está na atitude censora do autor, não com respeito à própria sociedade, mas com respeito aos tipos que ela representa. Nesse contexto, quando uma brincadeira agride um personagem de ficção, o leitor chega ao riso sem se preocupar com a questão da agressividade, uma vez que a vítima é um ser ficcional, apesar de que essas questões não eximam o caráter agressivo desse riso (ARELLANO, 2006, p. 348).

Paralelamente, conforme Close, o que caracteriza a sátira sociomoral de Cervantes é

la naturaleza humana depravada, por el pecado, rebelde a la convivencia social, tercamente entrometida, etc., y su retórica habitual la constituyen la diatriba elegante, el aforismo cáustico, la convención razonada. (CLOSE, 1990, p. 501)

Por isso, a narrativa do "Coloquio" é direcionada para o comedimento, para a indulgência, com o intuito de buscar em seu destinatário algo que o redima, que lance “mais luz” em sua condição. Em outros termos, seria uma mudança de perspectiva, cuja finalidade está na transição do riso mordaz para o burlesco. (CLOSE, 1990, p. 502).

Assim, os cães conseguem retratar por intermédio desse colóquio, toda as questões sociais de forma racional, comedida, sem utilizar um discurso que se aproxime 
de um sermão ou de uma lição de moral, a ser observada e seguida. Para Riley, Cervantes nos cede no "Coloquio" "[...] una pareja que narra y comenta, siempre concientes de que siguen formando parte del mundo vicioso al que han renunciado, mundo cuyos defectos ven con toda claridad" (RILEY, 1988, p. 93).

Essa clareza, que coloca em evidência as falhas morais dos personagens secundários da novela, destaca também uma das práticas vista como deformação e prevenida pelos cães ao longo de toda a novela: o ato de pregar ou repreensão de cunho religioso, isto é, o sermão. Citado em muitas passagens da novela pelos cães, o sermão consiste para eles em algo pernicioso, cujo discurso se equipara ao da murmuração.

É importante notar o parecer de Berganza expresso na resposta dada a Cipión, após ouvir seus conselhos:

BERGANZA. Yo tomaré tu consejo, y esperaré con gran deseo que llegue el tiempo en que me cuentes tus sucesos; que de quien tan bien sabe conocer y enmendar los defectos que tengo en contar los míos, bien se puede esperar que contará los suyos de manera que enseñen y deleiten a un mismo punto. (CERVANTES, 2005, p. 659)

Verifica-se no início desse fragmento o tom irônico utilizado pelo protagonista diante das advertências de Cipión. Ao expor seu grande desejo em escutar os acontecimentos vividos por seu companheiro, Berganza demonstra o anseio por estabelecer um comparativo entre as narrativas, levando em conta todas as censuras de Cipión referentes ao seu relato, desde o instante em que se depararam com o dom da fala. A ironia do protagonista está contida nas questões implícitas nesse momento da novela, como se o cão fizesse uma espécie de retrospectiva das censuras do amigo, através da afirmação: "[...] de quien tan bien sabe conocer y enmendar los defectos que tengo en contar los míos (sucesos)". Por intermédio dessa observação de Berganza, com 
respeito às repreensões de Cipión, pode-se verificar que o personagem estabelece uma relação de equivalência entre essas censuras com o discurso de um pregador.

Diante desse raciocínio, observa-se que o sermão nesse diálogo canino se situa no mesmo plano de equivalência ao ser comparado com a sátira e a murmuração. Percebido como uma fala tendenciosa com o intuito de falar mal de alguém, seja esse destinatário individual ou coletivo, o sermão no "Coloquio" acaba sofrendo certo rebaixamento ao ser equiparado com essas duas formas discursivas. Isso posto, para Illades, murmurar, satirizar, pregar e filosofar são práticas discursivas (ILLADES, 2008, p. 165) de relevância social, cujo denominador comum é estabelecido pela murmuração. Nesse sentido, ao explicar essa equiparação feita entre as três formas discursivas, o pesquisador afirma em seu trabalho que a murmuração "morde" com as palavras. Já o pregador fala mal do pecado e dos pecadores, e o escritor satírico, juntamente com o filósofo cínico, “mordem” verbalmente, sejam costumes sociais reprováveis, seja com respeito às questões inerentes ao ser ou à sua conduta em sociedade. Em outras palavras, para Illades, o sermão e a sátira se equiparam, tendo em vista que ambos falam mal de alguém e que o pregar é percebido como uma ação que transita entre o divino, o grave e o burlesco. (ILLADES, 2008, p. 164-165).

Paralelamente, cabe acrescentar que segundo Hansen, a sátira pertence ao gênero epidítico ou demonstrativo, pois institui o louvor, a censura; quanto ao sermão, comumente utiliza-se do gênero deliberativo, por introduzir um conselho pautado em ações futuras, mesmo porque "só se aconselha o que é bom e se desaconselha o que é mau." segundo afirmação dos retores antigos. ${ }^{46}$

46 HANSEN, João Adolfo. Educando príncipes no espelho. In: FREITAS, Marcos Cezar de; KUHLMANN Jr., Moysés (Orgs.). Os intelectuais na história da infância. São Paulo, Cortez, 2002. p.71. 
Assim, retomando o colóquio canino, Berganza aproxima as advertências de Cipión ao discurso de um pregador em função de suas insistentes censuras. Essas censuras, nesse caso, são também comparadas pelo protagonista a um discurso satírico, pois têm como função reprovar os vícios. No entanto, como Cipión já citara Juvenal, Berganza aproveita-se da sentença para introduzir em sua réplica a esperança de que, quando chegue o momento no qual o amigo comece a narrar seus sucessos, estes “enseñen y deleiten a un mismo punto", ou seja, menciona de forma irônica a poética de Horácio.

É interessante notar essas questões relacionadas ao ensinar e deleitar contidas na obra horaciana e a importância que o autor atribui à obra poética, no sentido de que seja instrutiva, divertida, apresentando coisas agradáveis e proveitosas, com temas que contenham uma verdade próxima do possível.

Dessa maneira, fica evidente, através da fala de Berganza, o preceito de que a sátira para Cervantes assume um tom mais benevolente, ao estilo de Horácio, ou, como diria Close referindo-se à novela, seu discurso institui uma moderação do didatismo abrasivo da sátira, mediante distintos mecanismos de atenuação, desvio e sublimação. Ademais, observa-se a submissão desse incrível colóquio canino a uma firme, embora não constritiva, teia de explicações racionais (CLOSE, 2007, p. 76). Esse intento explica a contínua transformação da sátira em gêneros fronteiriços. No instante em que ela não surge no diálogo canino de maneira autônoma, para o pesquisador a sátira cervantina sempre apresentará a tendência a se converter em comédia, fábula ou entremez, direcionados contra objetivos morais e sociais (CLOSE, 2007, pp. 76-7).

Nesse aspecto, através da fala de seus personagens, a sátira cervantina assume um papel mais ameno, menos mordaz, conforme os preceitos horacianos, cuja obra, ao contrário da de Juvenal, introduz um novo tom aos discursos, sempre primando pelo 
didatismo, pela moderação tanto na oratória quanto nos textos, ou seja, "misturar o útil com o doce" e "ensinar e deleitar" (HORÁCIO, pp. 745-57).

É importante acrescentar que Berganza, nessa passagem da novela consegue, deliberadamente, inverter os papéis. Essa inversão introduz certa comicidade na narrativa, pois o protagonista assume a posição do amigo interlocutor; de discípulo transforma-se em mestre e consegue se opor às afirmações anteriores de Cipión com respeito à dificuldade em não se escrever sátiras.

Com isso, mesmo que a narrativa dos futuros sucessos de Cipión se aproxime de um discurso satírico, esse discurso, segundo as expectativas do cão Berganza, deve se caracterizar por seu aspecto mais deleitoso e indulgente, muito embora censure a maldade e os pecados humanos. A sátira nesse instante da novela pode apropriar-se de outras formas discursivas, como o sermão e de alguns aspectos do gênero pastoril, embora sempre haverá uma diminuição na tensão desse discurso, pois serão introduzidas formas mais amenas para que a censura expressa pelos personagens caninos, direcionada aos personagens secundários, valorize mais o efeito risível, mais o deleite. 


\section{O gênero pastoril como modelo questionável - um mundo às avessas}

Jamás viene la fortuna a manos llenas, ni concede una gracia que no haga expirar con un revés.

William Shakespeare

Como mencionado anteriormente, o gênero pastoril foi muito popular no século XVI e até meados do XVII, juntamente com os livros de cavalaria. Entretanto, apesar da grata acolhida dos leitores da época, havia uma censura a esses gêneros tanto proveniente de escritores humanistas quanto de membros do clero, a qual se pautava pela falta de verossimilhança presente nessas produções, em função de seu tema inverossímil. Assim, ao se observar as novelas pastoris, levando-se em conta as características do personagem, no caso o pastor, fica evidente esse distanciamento, no momento em que esse pastor apresenta um discurso elevado, procedente de um indivíduo de aparência altiva e elegante, contrapondo-se à figura dos pastores reais, gente simples e analfabeta - pobres trabalhadores do campo do século XVII.

Desse modo, através de um cenário bucólico, em que a natureza tem um papel preponderante, o pastor novelesco emergia no gênero como protagonista de um discurso, acompanhado por uma musicalidade concebida por instrumentos de sonoridade singular, como os de sopro e cordas, com a finalidade de compor um panorama idílico para o tema amoroso, tudo com o propósito, como diria Berganza, de servir de "entretenimiento de los ociosos" (CERVANTES, 2005, p. 662).

Com base nessa afirmação do protagonista, inicia-se a passagem de "El coloquio de los perros" que irá apresentar um questionamento de Berganza ao gênero pastoril, 
pois o personagem estabelece um comparativo dos pastores seus amos com os constantes dos livros lidos pela esposa do dono do rebanho, conforme o fragmento a seguir:

BERGANZA. [...] en aquel silencio y soledad de mis siestas, entre otras cosas, consideraba que no debía de ser verdad que había oído contar de la vida de los pastores; a lo menos de aquellos que la dama de mi amo leía en unos libros cuando yo iba a su casa, que todos trataban de pastores y pastoras, diciendo que se les pasaba toda la vida cantando y tañendo con gaitas, zampoñas, rabeles y chirumbelas, y con otros instrumentos extraordinarios. (CERVANTES, 2005, pp. 659-60)

Conforme afirmação do protagonista, os pastores novelescos passavam a vida cantando e tocando seus instrumentos musicais, ao contrário dos pastores pertencentes ao seu cotidiano, com seus modos rústicos, consequência do trabalho duro do campo que a guarda do rebanho exigia. Dessa forma, o protagonista questiona a matéria contida naquelas obras, pois apresentam um discurso inverossímil, ou seja, um discurso que dista dos princípios perseguidos pelas produções escritas da época, cujo tema deve encerrar uma verdade possível dentro do universo ficcional. Nesse sentido, faltaria a essas composições uma adequação entre o caráter do personagem com o ofício que ele representa. Essa opinião de Berganza irá descrever um dos aspectos pertencentes ao conceito de decoro.

Assim, para se compreender a função do decoro nessas obras, cujos discursos remetem ao universo da Arcádia, é oportuno observar os estudos recentes feitos por Rogélio Miñana. No capítulo que trata sobre "La lengua de los pastores en la Arcadia de Montemayor y Cervantes" (MIÑANA, 2002-6, pp. 99-101), o pesquisador analisa essa mesma passagem da novela exemplar "El coloquio de los perros" e afirma que na novela pastoril a expressão "o que se diz e como se diz" é um fator fundamental para caracterizar um personagem verossímil, pois seu discurso permite diferenciar o pastor 
rústico de seu oposto. Essa adequação entre o caráter do personagem e a maneira como se expressa, segundo o pesquisador, compunha nessa época o conceito de decoro. (MIÑANA, 2002-6, pp. 99-100).

Nesse sentido, conforme Miñana, o decoro pode ser entendido como a correspondência entre a caracterização interna do personagem e a externa, isto é, a maneira de ser desse personagem deve estar em concordância com seu comportamento, sua aparência, suas falas e ações, seja no enredo de um poema, seja no de uma narrativa.

Com essa configuração, um pastor de origem humilde, analfabeto, rude, deve se apresentar com um estilo rústico, ao contrário de um culto e nobre, disfarçado de pastor, que deverá recorrer a um estilo elevado. Essas são as discrepâncias apontadas por Berganza entre os pastores de sua convivência e os constantes nas novelas pastoris. Divergências que introduzem uma dicotomia (MIÑANA, 2002-6, p. 100) aparentemente simples. Entretanto, ao se pensar no decoro relacionado ao gênero pastoril, é nesse momento em que se torna mais ativo e complexo. Por isso afirma Miñana:

Frente a quienes defienden la semejanza a la realidad como principal criterio de lo verosímil, en la literatura bucólica es el modo de expresión, mucho más que las ocupaciones, origen o psicología de los personajes, el que constituye en último término la identidad del sujeto y, por lo tanto, su verdad poética.

De fato, o discurso do personagem é mais importante que sua origem social, pois a Arcádia não necessita reproduzir o mundo externo, mas pode encontrar sua verdade poética no mundo ficcional, por intermédio da linguagem e da imitação de modelos prévios. $^{47}$

\footnotetext{
${ }^{47}$ Um exemplo disso está na passagem extraída do Prólogo da La Galatea de Cervantes, no trecho que o autor afirma que: "[...] no temeré mucho que alguno condemne haber mezclado razones de filosofía entre algunas amorosas de pastores, que pocas veces se levantan a más que a tratar cosas del campo, y esto con
} 
Paralelamente a essas análises, Avalle-Arce, em seus estudos sobre a novela pastoril espanhola, em um capítulo dedicado a Cervantes, diante dessa problemática introduzida pelo personagem canino em "El coloquio de los perros", destaca que essa censura tem como alvo a verdade poética, no sentido de que esta não se ajusta à verdade histórica, transformando aquela em uma escrita mentirosa (AVALLE-ARCE, 1974, p. 255). É útil verificar que de certa forma se determina uma equiparação dessa característica com o diálogo canino, no instante em que os dois discursos se afastam dos modelos artísticos. Esse distanciamento, no caso do colóquio entre Cipión e Berganza, se justifica pela própria novela ou pela impossibilidade de existir um diálogo entre dois cães, impossibilidade que as personagens atribuem aos céus, ou, como a classificou o protagonista Campuzano em "El casamiento engañoso": "†...] esos sueños o disparates" (CERVANTES, 2005, p. 647).

Para Hansen, a censura do protagonista se pauta na tipologia do pastor como tipo rústico próprio da bucólica e do estilo humilde, contrapondo-se aos pastores da novela pastoril, os quais se apresentam em estilo elevado. ${ }^{48}$

Ao rever a narrativa do "Coloquio", o que se constata é que Berganza, ao mesmo tempo que censura essas discrepâncias entre seus amos e os personagens das novelas pastoris, enaltece sua verdade poética, descrevendo maravilhado esse universo, ao retomar algumas das mais famosas novelas do gênero.

Essa retomada se presentifica na passagem em que o protagonista faz uma série de referências à pastoril; cita La Arcadia de Lope de Vega, faz alusão a Aurora e Tétis, deusas do amanhecer e do mar, respectivamente, cita o pastor Elicio, personagem de $L a$

su acostumbrada llaneza". (CERVANTES, 1824, f. VII) Cervantes reconhece explicitamente ter incorporado no discurso de seus pastores uma matéria filosófica. Entretanto, o autor os intitula como "disfrazados pastores", ou seja, institui uma justificativa com relação à fala culta dos personagens, fazendo com que os critérios pertencentes à verossimilhança, presentes na composição do conceito de decoro, fiquem assegurados. (MIÑNA, 2002-6, p. 105).

${ }^{48}$ HANSEN, João A. Observação feita por ocasião da qualificação, em 18 set. 2014. 
Galatea do próprio Cervantes, sem contar com o grande pastor Fílida, da novela pastoril de Luis Gálvez de Montalvo El pastor de Fílida. Berganza recordava outros livros da mesma espécie, “[...] pero no eran dignos de traerlos a la memoria” (CERVANTES, 2005, p. 661).

É interessante perceber a ironia do personagem com respeito às obras pastoris, no sentido de que algumas não mereciam ser lembradas - uma atitude mordaz por parte do protagonista ao rechaçar, de forma implícita, algumas escrituras do gênero. Essa censura poderia ser tomada como uma aversão à Arcádia como um todo, algo improvável, levando-se em conta que Cervantes iniciou seus escritos com La Galatea, uma novela pastoril, e morreu prometendo sua continuação (AVALLE-ARCE, 1974, p. 254). Deve-se ainda notar que as obras mencionadas por Berganza são as mesmas salvas no capítulo que trata do grande "escrutinio" feito pelo cura e pelo barbeiro na biblioteca de Dom Quixote (CERVANTES, 2004, pp. 60-9).

Assim, para que essas questões presentes na censura do protagonista se aclarem, convém retomar as alegações contidas no fragmento acima e estabelecer um paralelo com as observações contidas no prólogo das Novelas ejemplares, no qual Cervantes compara essas escrituras com "[...] una mesa de trucos donde cada uno pueda llegar a entretenerse [...]" (CERVANTES, 2005, p. 80), ou seja, são discursos que estão a serviço do entretenimento, tal qual a alegação de Berganza com respeito aos livros pertencentes à Arcádia.

Entretanto, os comentários maliciosos do personagem não passam despercebidos por Cipión, que o adverte conforme o trecho a seguir: "Aprovechándote vas, Berganza, de mis avisos; murmura, pica y pasa, y sea tu intensión limpia, aunque la lengua no lo parezca." (CERVANTES, 2005, p. 661). 
Cipión não deixa de censurar a maneira com que Berganza tece seus comentários, sempre preocupado em proteger o discurso contra uma murmuração destrutiva, pois a partir do momento em que receberam o dom da fala, os cães têm por obrigação usar esse prodígio por intermédio de uma linguagem, cujo propósito é servir de instrumento para alcançarem um crescimento moral. Sendo assim, é interessante perceber que o cão orienta Berganza no sentido de não se estender nas falas maledicentes, já que essa murmuração, como se sabe, é inevitável. Porém, Cipión lhe aconselha: "murmura, pica y pasa”, isto é, para que não seja instituído um discurso, com uma matéria que se apresente tão extensa a ponto de se converter em uma fala difamatória, em função da impulsividade do personagem. Na sequência, Berganza responde:

BERGANZA. En estas materias nunca tropieza la lengua si no cae primero la intención, pero si acaso por descuido o por malicia murmurare, responderé a quien me reprehendiere lo que respondió Mauleón $^{49}$, poeta tonto y académico de burla [...] a uno que le preguntó que qué quería decir Deum de Deo; y respondió que "dé donde diere". (CERVANTES, 2005, p. 661)

\footnotetext{
49 "Cervantes, por entonces debió de frecuentar en Madrid la Academia Imitatoria, y en ella conocería a aquel estrafalario asiduo, tristemente inmortalizado en el Quijote: 'un poeta que andaba los años pasados en la corte, llamado Mauleón, el cual respondía de repente a cuantos le preguntaban; y preguntándole uno que qué quería decir Deum de Deo, respondió: Dé donde diere'. En 'El coloquio de los perros': 'Mauleón, poeta tonto y académico de burla de la Academia de los Imitadores'. Se desconoce la fecha exacta en que funcionó esta Academia; pero probablemente desde la entrada de la Primavera de 1585 hasta comienzos de 1586, no por deducirse de las menciones de Cervantes, sino de un apotegma de Juan Rufo, el único que suministra datos de aquélla. [...] 'Fundóse en Madrid la Academia Imitatoria, cuyos principios parece que prometían que había de durar como imitadora de las famosísimas de Italia; porque el presidente, aunque era muchacho, era rico y principal, y siendo con esto buen poeta y de buen ingenio, acariciaba con liberalidad y cortesía a los hombres de aquella profesión. Esforzaba también las esperanzas de este noble edificio la multitud de personas eminentes que le servían de columnas, y finalmente el concurso de oyentes calificados, grandes, títulos y ministros del Rey, que iban a oír con aplauso y atención. Pues como, tras todo esto, la Academia susodicha se acabase tan en flor que no cumplió el año del noviciado, y le preguntase el señor de la Horcajada [a Juan Rufo] la causa de haberse logrado tan mal, respondió: 'Como el presidente era niño, murió la Academia de alferecía'. Ignórase de todo punto quién fuera este joven presidente y entre qué próceres y poetas vio Miguel al infeliz académico Mauleón”. Disponível em: http://hhh.gavilan.edu/fmayrhofer/spanish/astrana/tomoIII/p0000014.htm Acesso em: 21 ago. 2012.
} 
Para efeito de compreensão, dividir-se-á o parágrafo em duas partes. A primeira se baseia na declaração de Berganza com relação à própria fala, ou seja, para o cão não se discorre sobre nada que não se tenha a intenção de fazê-lo, até mesmo porque falar sobre as falhas humanas significa cuidar dos próprias falhas. Para Antonio Ríos Rojas (2006, p. 5) em seu artigo sobre a novela "El coloquio de los perros", no capítulo que discute sobre o trato discreto da linguagem na narrativa, as questões abordadas pelos cães no "Coloquio" estão relacionadas ao comportamento humano, que nesse contexto é o comportamento censurável dos próprios amos de Berganza. Com base nesse argumento, o pesquisador afirma que observar o modelo humano e falar sobre ele é um exercício no cuidado de si mesmo por intermédio da linguagem. (RÍOS ROJAS, 2006, pp. 5-6). Assim, Cipión procura em todo o momento cuidar dessa linguagem, incentivando Berganza para que também o faça, com o propósito de alcançar uma melhora moral e um fim virtuoso (RÍOS ROJAS, 2006, p. 5). Entretanto, mesmo ciente desses preceitos, Berganza deixa claro que essa fala pode corresponder a certa adequação no que se refere ao próprio discurso, mas, dependendo das intenções de quem o profere, pode transitar no terreno da murmuração, da maledicência, apesar da aversão cervantina com respeito ao discurso difamatório. ${ }^{50}$

Nesses termos, ao fazer um comparativo entre a escritura de "El coloquio de los perros" com a de Dom Quixote, por exemplo, pode-se verificar que esta última apresenta um diálogo entre dois amigos, no caso cavaleiro e escudeiro, que são opostos em quase tudo (p. 10). Por esse motivo, o modelo que representa a relação de Dom Quixote e Sancho acaba apontando para um confronto permanente. De forma equivalente ocorre entre Cipión e Berganza com respeito à própria fala, bem como no

\footnotetext{
${ }^{50}$ Em sua obra Viaje del Parnaso, Cervantes declara: "Nunca voló la humilde pluma mía/ por la región satírica, bajeza/ que a infames premios y desgracias guía".
} 
cuidado de evitar a murmuração, o que se supõe "ser una hazaña de imposible realización” (RÍOS ROJAS, 2006, p. 9). Nesse aspecto, para o pesquisador,

No deja de llamar la atención el que Cipión sugiera constantemente a Berganza que no murmure acerca de sus historias (lo que no consigue Berganza), y que la ejemplar novela concluya sin que Cipión - el que pretendía no murmurar - cuente algo acerca de sus dueños. Cervantes sabía $[. .$.$] que contar sin combatir era misión imposible. De ahí que$ fuera necesario el callar final de Cipión. (RÍOS ROJAS, 2006, p. 6)

Dessa maneira, ao rever a segunda parte do parágrafo, Berganza mostra sua despreocupação diante das advertências de Cipión, recordando a resposta dada por Mauleón, quando lhe perguntaram o significado de "Deum de Deo", ao que respondeu: "dé donde diere". A resposta retrata o descaso do protagonista com relação às repreensões do amigo, uma vez que a fala tendenciosa ou murmurante é parte integrante de seu relato. Mesmo assim, as censuras de Cipión com relação a essa linguagem se estenderão até o final da narrativa, pois essa fala maliciosa de Berganza sugere uma conduta inadequada, uma linguagem inapropriada, ao se pensar na possível alegoria do homem discreto, representada e perseguida por esses protagonistas caninos.

Com base nesse raciocínio, as preocupações de Cipión se justificam levando-se em conta os critérios que regem o princípio do decoro presentes também no tipo intelectual do discreto, pois nos séculos XVI e XVII o decoro tendia a ser concebido levando-se em conta o tipo ou a ordem social (CLOSE, 2007, pp. 150-1). Além disso, constituía um reconhecimento da obrigação do "ser", não como uma "autoafirmação", mas ao identificar a obrigação de ser coerente com a posição que se ocupa em sociedade. Com essas características, para Close, vida e produções escritas convergem e essa convergência é marcada precisamente pela definição de decoro proposta por Juan de Valdés no parágrafo a seguir, extraído de seu livro Diálogo de la lengua: 
Cuando queremos decir que uno se gobierna en su manera de vivir conforme al estado y condición que tiene, decimos que guarda el decoro. Es propio este vocablo de los representadores de comedias, los cuales entonces se decía que guardaban bien el decoro, cuando guardaban lo que convenía a las personas que representaban. (CLOSE, 2007, p. 151)

Do ponto de vista da prática social, conforme as afirmações do humanista, as atitudes de um indivíduo devem ser coerentes com seu estado e condição social; no caso de um cortesão, sua conduta e linguagem devem conter certa erudição, apresentar clareza e determinado refinamento, embora essas qualidades não sejam distintivas dos cortesãos, mas daqueles que são tidos como discretos, como mencionado anteriormente. Ao mesmo tempo, para Valdés os atores de comédias devem guardar o decoro em se tratando das personagens que representam, pois se apresentarem uma peça cômica, em conformidade com o gênero, devem reproduzir imagens, cujo efeito está em promover o riso, seja esse inofensivo ou nocivo. Dessa forma, o elemento alvo dessa comicidade pode ser encontrado no baixo, na plebe com seus vícios e fraquezas, na delinquência, como é o caso dos pícaros, prostitutas espertas, ladrões, gente corrupta que, de acordo com suas indignidades, suscita um efeito risível, próprio do gênero cômico. O que se pode perceber é que esses aspectos elencados não são encontrados em produções, por exemplo, pertencentes ao trágico ou ao épico, pois são concernentes ao cômico. Daí a advertência de Cipión a Berganza, ao afirmar que sua resposta era de um simples, mas, se ele era um discreto ou tivesse a intenção de sê-lo, "nunca has de decir cosas de que debas dar disculpa" (CERVANTES, 2005, p. 661).

Nesse caso, a resposta de Berganza estaria na contramão do decoro social; ao pensar na advertência de Cipión com relação à linguagem ou ao exemplo anedótico utilizado pelo protagonista, sua conduta estaria no âmbito do disparate, própria de um ser desprovido de qualquer entendimento ou capacidade de integrar-se dentro de um 
círculo de práticas de representações, típicas de um discreto. Com base nesses aspectos, Maria Augusta da Costa Vieira, em seus estudos sobre a discrição de Cipión em "El coloquio de los perros", observa que o personagem, além de ouvinte da história de vida de Berganza, também participa como interlocutor em assuntos relacionados especialmente ao modo de narrar, às questões éticas e "[...] con la vida humana en su percepción más profunda, por medio del entrelazado de múltiples sustratos con los cuales el texto dialoga." (VIEIRA, 2011, p. 102).

Nesses termos, Cipión assume a posição de mediador desse relato, assegurando que pelo menos o decoro no discurso seja preservado, embora a novela apresente certa ironia e comicidade ao se pensar no tipo intelectual do discreto, sendo possivelmente representado pela figura de dois cães.

$\mathrm{Na}$ sequência, Berganza segue seu relato e retoma com mais vigor o tema da novela pastoril, estabelecendo uma comparação mais veemente entre os pastores constantes daqueles livros e os pastores seus amos. Aqueles passavam a vida cantando com vozes delicadas, acompanhados de instrumentos maravilhosos; estes, com vozes roucas, gritavam e grunhiam um "Cata el lobo do va Juanica”, até seus nomes e posturas no campo eram distintos, o que leva o protagonista a concluir:

BERGANZA. [...] que todos aquellos libros son cosas soñadas y bien escritas para entretenimiento de los ociosos y no verdad alguna, que, a serlo, entre mis pastores hubiera alguna reliquia de aquella felicísima vida [...]. (CERVANTES, 2005, p. 662)

É oportuno observar que além de instituir uma censura severa com respeito às incongruências observadas entre o estilo rude de seus amos pastores e a vida onírica da pastoral, Berganza, também, faz referência a algumas tópicas do gênero arcádico quando descreve, $\log$ o na sequência, “[...] aquellos amenos prados, espaciosas selvas, sagrados montes, hermosos jardines, arroyos claros y cristalinas fuentes [...]”, descrição 
que de acordo com Close, retrata um certo apreço pelo espaço idílico, não por parte de Berganza, mas do próprio Cervantes, ao introduzir um equilíbrio diante da opinião negativa de seu personagem. (CLOSE, 2007, p. 79). Com isso, fica evidente a censura não ao gênero pastoril, como já mencionado, mas a um modelo de pastor que dista consideravelmente de seus atuais amos, ou seja, "aquilo que deveria ser, mas não é".

Ao mesmo tempo, essa censura ou discurso satírico sempre virá seguida de uma quebra em sua ferocidade instituída pelo cão Cipión, transformando a narrativa em algo mais brando, mais amigável. Um exemplo dessa atitude cervantina com relação à sátira pode ser encontrado no diálogo entre Dom Quixote e Dom Diego de Miranda (El del Verde Gabán), quando este lhe conta sobre o desejo de seu filho de ser um poeta:

Riña vuesa merced a su hijo se hiciere sátiras que perjudiquen las honras ajenas, y castíguele, y rómpaselas; pero si hiciere sermones al modo de Horacio, donde reprehenda los vicios en general como tan elegantemente él lo hizo, alábele [...]. (CERVANTES, 2004, p. 668)

Diante das afirmações de Cervantes empregada nas declarações de seu “cavaleiro andante", observa-se que conforme Close, ao analisar um outro episódio de Dom Quixote, que trata sobre o governo de Sancho Pança em "la insula Barataria": "La resonancia simbólica del episodio es incuestionable y deriva de su referencialidad censuradora y del simultáneo desvanecimiento de su blanco satírico.” (CLOSE, 2007, p. $80)$.

Assim, quando Cervantes introduz em sua narrativa uma censura, seja através de um elemento alegórico, seja por intermédio de um discurso manifesto, procura amenizála por meio de uma linguagem mais comedida, pois, segundo Close, o tratamento da sátira na obra cervantina segue motivos de ofício. No caso do "Coloquio", o discurso se pauta por direcionar uma censura a determinados tipos e práticas sociais, tais como: certos grupos parasitas, delinquentes, alguns loucos, poetas e poetastros, dispensando 
sua censura mais feroz aos açougueiros, ciganos, mouros e bruxas (CLOSE, 1990, pp. 499-500). O pesquisador verifica a ausência de temas recorrentes em obras da tradição satírica, como: a mulher ou a sexualidade, a política ou a religião.

No entanto, deve-se observar nesse momento da novela que os fatos e os afetos do protagonista com respeito ao campo concorrem em uma relação de proporcionalidade, pois à medida que a diferença entre os amos de Berganza aumenta em comparação com os pastores contidos nas novelas pastoris, cresce o desencanto do protagonista com respeito à vida do campo e seu ofício de cão pastor. Toda aquela vida voltada ao resgate de valores cristãos, agora se vê reduzida ao simples cumprimento da tarefa de "perro pastor", cujo ofício lhe proporciona apenas comer o pão de seu suor e trabalho, pois “[...] la ociosidad, raiz y madre de todos los vícios, no tenía a ver conmigo" (CERVANTES, 2005, p. 663), ou seja, bastava os pastores seus amos dizerem: "Al lobo, Barcino", que Berganza corria vales, morros, selvas e barrancos, voltando de sua tarefa com as patas machucadas, sem conseguir encontrar nenhum lobo devorador de rebanho, como mostra o trecho a seguir:

BERGANZA. Desesperábame de ver de cuán poco servía mi mucho cuidado y diligencia. Venía el señor del ganado, [...] culpaba a los pastores por negligentes y mandaba castigar a los perros por perezosos, llovían sobre nosotros palos y sobre ellos reprehensiones. (CERVANTES, 2005, p. 664)

Diante da ineficácia de suas ações, Berganza decide encontrar o lobo, não seguindo pelo caminho tradicional, mas permanecendo próximo ao rebanho, ou seja, iria fazer o percurso inverso aos seus companheiros de matilha.

BERGANZA. Cada semana nos tocaba a rebato, y en una escurísima noche tuve yo vista para ver los lobos, de quien era imposible que el ganado se guardase. [...] desde allí oteé y vi que dos pastores asieron de un carnero de los mejores del aprisco, y le mataron, de manera que 
verdaderamente pareció a la mañana que había sido su verdugo el lobo. (CERVANTES, 2005, p. 664)

É importante salientar no que se refere ao relato de Berganza, que os acontecimentos se desenrolam em um tempo pretérito, em comparação ao tempo presente no Hospital da Ressurreição, onde os fatos são narrados pelo personagem. Até o momento acima relatado, o cão não possuía o dom da fala, ou, como ele mesmo diria: "hallábame mudo". Nesses termos, nada poderia ser feito no sentido de denunciar a ação inescrupulosa de seus amos. Devoravam o gado e lançavam a culpa em uma suposta ação de lobos - com um misto de admiração e angústia, o cão sofria os castigos injustamente. O tema dessa passagem do "Coloquio" faz referência à desonestidade e à mentira, um assunto recorrente na sátira sociomoral, que aqui também faz alusão à simulação ou fingimento contido nas atitudes dos pastores. Assim, a existência de um lobo a devorar o rebanho é simulada através da teatralização de acontecimentos inexistentes, ou seja, o produto do falso. Nesse instante da novela, mediante a utilização de termos em antítese, Berganza reforça sua indignação diante dos pecados humanos:

BERGANZA.i Quién podrá remediar esta maldad? ¿Quién será poderoso a dar a entender que la defensa ofende, que las centinelas duermen, que la confianza roba y el que os guarda os mata? (CERVANTES, 2005, p. 665)

Sem dúvida, nesse episódio a figura do lobo, segundo Ríos Rojas, será apresentada de forma inocente, comparada com a astúcia do homem, pois a vida natural surge mais pura e limpa comparada aos segredos humanos. O pessimismo de Berganza chega ao ponto máximo diante das ações de seus amos, até mesmo porque o cão se vê diante da impossibilidade de pôr em evidência tais enganos, pelo fato de não dispor da linguagem (RÍOS ROJAS, 2012, pp. 8-9). Por outro lado, para Close, a simetria existente entre o comportamento dos pastores e dos frequentadores do matadouro fica 
evidente. Além disso, estes, como os demais da "hampa sevillana", desfrutam da proteção do poder jurídico da cidade, enquanto Cervantes projeta as experiências de Berganza como cão pastor, evocando as imagens do universo pastoril com a finalidade de usá-las como "una alegoria del abuso del poder político y eclesiástico" (CLOSE, 2007, p. 72).

Dessa maneira, a angústia de Berganza, percebida através desses questionamentos, deixa entrever claramente seu profundo desapontamento. Para Close, “el foco de atención se aparta de la sociedad en su aspecto público para fijarse en las relaciones entre sujetos individuales" $(2002$, p. 73$)$. Por esse motivo, para o estudioso, a fase sevilhana do "Coloquio" sugere de maneira implícita o abuso de poder associado ao serviço leal ou desleal, conforme a opinião de Cipión a seguir:

CIPIÓN. [...] porque no hay mayor ni más sotil ladrón que el doméstico, y, así, mueren muchos más de los confiados que de los recatados, pero el daño está en que es imposible que puedan pasar bien las gentes en el mundo si no se fía y se confía. Mas quédese aquí esto, que no quiero que parezcamos predicadores. (CERVANTES, 2005, p. 665)

A afirmação de Cipión institui a alegoria do mau pastor ${ }^{51}$ e aponta para o dilema de não se poder fiar nem confiar em ninguém, com o propósito de não ser enganado. $\mathrm{O}$ personagem recorre ao emprego dos jogos de palavras, "confiados y recatados" e "se fía y se confía" a fim de institui uma quebra no tom desalentador do discurso de Berganza, com a finalidade de obter certo efeito risível. Com isso, o personagem estabelece uma aproximação entre o elemento sério e o cômico, pois se em um primeiro momento

\footnotetext{
${ }^{51}$ Segundo Close, essa alegoria do mau pastor, do abuso de poder, se vê representada na obra do século XV intitulada Coplas de Mingo Revulgo de 1464, a qual se aproxima dessa temática abordada no Coloquio cervantino, conforme a passagem a seguir disponível em: http://saavedrafajardo.um.es/web/archivos/libros/Libro0186.pdf. Acesso em: 30 ago. 2012. “¡Oja, oja los ganados/ y a la burra con los perros/ cuáles andan por los cerros/ perdidos, descarriados![...]

Oh, mate mala ponzoña/ a pastor, de tal manera,/ que tiene cuerno con miera/ y no les unta la roña;/ ve los lobos entrar/ y los ganados balar;/ él, risadas en oírlo;/ ni por eso el camarillo/ nunca deja de tocar."
} 
apresenta esses jogos de palavras para descrever uma situação vergonhosa com certa comicidade, no instante seguinte introduz um tema de caráter sério, ou seja, a impossibilidade de se viver sem confiança. No entanto, como Cipión é a voz moralizadora do diálogo canino, interrompe seu discurso para não se parecer com um pregador.

Em resposta ao amigo, Berganza informa sua determinação em deixar aquele oficio de cão pastor, pois nada poderia fazer contra os atos de vileza e as mentiras de seus amos.

Assim, fica evidente nesse capítulo do "Coloquio" a utilização do gênero pastoril, a princípio servindo de base para os preceitos cristãos que percebem o campo como o lugar onde se encerra toda a virtude e pureza presentes no ofício do pastor, contrapondo-se com os vícios da cidade. Nesse aspecto, torna-se clara a necessidade do homem em buscar na natureza a virtude perdida. Da mesma forma, quando Berganza fugiu do Matadouro e chegou ao campo, acreditou ter encontrado sua verdadeira missão: defender os humildes dos poderosos, por intermédio do ofício de cão pastor.

Mas, à medida que o personagem ingressa no mundo das novelas pastoris, certos questionamentos começam a surgir, afinal suas características distavam consideravelmente dos modelos representados por seus amos pastores.

Vê-se assim que, ao perceber as ações desleais de seus amos, Berganza admite estar em um mundo às avessas, pois verifica uma relação de equivalência entre os pastores, seus atuais donos, com os frequentadores do Matadouro.

Por isso, tudo é desalento, tudo é decepção para o jovem mastim, que agora prefere escolher outro ofício "donde por hacerle bien, ya que no fuese remunerado, no fuese castigado."(CERVANTES, 2005, p. 665). Nesse instante da novela, o personagem decide voltar a Sevilha. 
III. BERGANZA, O RICO COMERCIANTE E OUTROS ACONTECIMENTOS 


\section{Berganza e as relações amo e criado}

La virtud es el arte de vivir bien y con

rectitud.

San Agustín

Um dos momentos mais singulares da novela exemplar "El coloquio de los perros", se é que há algum que não o seja, é aquele que Berganza, diante das mentiras e da falta de lealdade dos pastores seus amos para com o dono do rebanho, decide deixar o campo, o ofício de cão pastor, voltar à Sevilha e servir na casa de um rico comerciante.

Essa singularidade se justifica porque, neste capítulo da novela, Berganza não só descreverá sua permanência na casa do novo amo, como também as relações que estabelecerá com a família, conduzindo-o ao curioso acontecimento que o fará frequentar um dos colégios dirigidos pela Companhia de Jesus, sem contar com a possível ligação de cumplicidade desenvolvida entre Berganza e a escrava da casa.

Nosso interesse está em analisar os acontecimentos descritos nessa passagem da novela e, evidentemente, as questões que serão abordadas pelos cães, geralmente pautadas em princípios morais, religiosos e filosóficos. Nesse sentido, a fim de detectar de que maneira o gênero cômico se constitui neste momento da obra, serão verificados temas tais como: as relações entre amos e criados, as aparências sociais, a lealdade, assuntos sempre introduzidos pelos protagonistas mediante digressões cômicas, frases de efeito que ridicularizam tanto a situação apresentada quanto os personagens envolvidos, como procuraremos demonstrar ao longo dessa análise.

Mas, retornando à cena em que Berganza expõe sua decisão de servir a um novo senhor, Cipión, admirado, lhe indaga com respeito à facilidade que o amigo possuía em 
encontrar um amo, tendo em vista as dificuldades passadas por um homem de bem na busca por um ofício.

CIPIÓN. ¿Qué modo tenías para entrar con amo? Porque según lo que se usa, con gran dificultad el día de hoy halla un hombre de bien señor a quien servir. Muy diferentes son los señores de la tierra del Señor del cielo; aquellos, para recibir un criado, primero le espulgan el linaje, examinan la habilidad, le marcan la apostura, y aun quieren saber los vestidos que tiene; pero para entrar a servir a Dios, el más pobre es más rico; el más humilde, de mejor linaje [...]. (CERVANTES, 2005, p. 665)

Por meio dessa comparação, Cipión aponta para um preceito cristão que se aproxima ao contido na passagem do Evangelho segundo Mateus 5,5: "Bemaventurados os humildes, pois eles receberão a terra por herança", ou seja, para servir a Deus, ao contrário dos senhores da Terra, outros valores são observados, como por exemplo a humildade, que nesse caso possui uma relação direta com aqueles que pouco têm.

Dessa forma, por intermédio das afirmações de Cipión pode-se presumir que Cervantes, por meio das falas desse personagem canino, faça uma referência implícita ao momento de crise social e econômica pelo qual passava a Espanha do século XVII (RÍOS ROJAS, 2006, p. 9).

Nesse sentido, para que se possa compreender as questões presentes nas afirmações de Cipión, faz-se necessário recordar que essa crise econômica na Espanha do século XVII teve como consequências: o desemprego e a miséria. Com isso, o vulgo, por causa da penúria que sofria, se via obrigado a cometer atos ilícitos contra seus amos, como os relatados por Berganza referentes aos pastores ${ }^{52}$ (p. 9). Por outro lado, os

\footnotetext{
${ }^{52}$ RÍOS ROJAS, Antonio. Comentario al "Coloquio de los perros" de Cervantes. Disponível em: http://pendientedemigracion.ucm.es/info/especulo/numero32/coperros.html. Acesso em: 04 jul. 2012.
} 
senhores descritos pelo interlocutor impunham todo tipo de exigências na busca por um criado, dentre elas: aparência, linhagem, pureza de sangue etc.

Antonio Maravall, ${ }^{53}$ quando analisa os "laços" de dependência entre amos e criados na sociedade dos primeiros séculos modernos, recorda que os serviçais na Alta Idade Média eram filhos de famílias de baixa nobreza. Quando atingiam a idade entre dez e doze anos eram enviados à casa de um senhor rico e poderoso que os alimentava e educava. Essa educação consistia no exercício da montaria, no manejo das armas, ler e escrever. Com isso, por dever a esse senhor sua formação e subsistência, esse criado lhe servia com fidelidade e gratidão (pp. 197-8).

Com o fim da Idade Média houve a deterioração desse ofício característico da sociedade cavalheiresca, até mesmo porque os senhores não conseguiam mais manter os grandes contingentes de cavalaria (p. 200). Assim, começa a desaparecer esse tipo de criado com função bélica, de origem nobre, permanecendo o criado doméstico. Esse criado já não pertencia a famílias de baixa nobreza, pois procedia do vulgo, seja das áreas rurais, sejam artesãos dos meios urbanos, voltados a ofícios manuais. Para eles não havia uma possível melhora de condição naquela sociedade corporativa, pela razão de não existir naquela época o que se entende nos tempos atuais por "mobilidade social". Foi também nesse período que se instituiu o ofício remunerado. Com base nesses aspectos, para Antonio Maravall, no momento em que se introduziu a remuneração em dinheiro,

[...] se desencadena un rápido proceso de erosión de las supuestas virtudes personales [...] y ese trato recíproco se convierte ahora en una prestación y contraprestación mecánicas [...] surge así ese tipo de relaciones acres, llenas de recíproca enemistad, inspiradas en el deseo

\footnotetext{
${ }^{53}$ ANTONIO MARAVALL, José La literatura picaresca desde la historia social (Siglos XVI y XVII). Madrid: Taurus, 1986.
} 
de ver perjudicada a la otra parte [...]. (JOSÉ ANTONIO

MARAVALL, 1986, pp. 199-200)

Por esse motivo, justificam-se as falas de Cipión, ao admirar-se da facilidade com que Berganza conseguia um amo, não somente pela crise econômica espanhola, mas também pelas muitas exigências dos senhores para com esses futuros criados. Por outro lado, para um homem de bem era difícil achar um senhor que não o reduzisse ao ganho de migalhas ou sobras. A hierarquia estabelecida entre estamentos era muito clara, isto é, recordando Santo Tomás de Aquino: “[...] que uno se refrene a sí mismo para no desear lo que es superior a él"54 - uma relação de respeito e obediência, imposta por intermédio de maus-tratos e castigos, nutrindo nesses serviçais afetos de desapego e desprezo para com seus amos. Uma tópica recorrente em algumas obras do século XVI, como é o caso da Comedia Himenea, de Bartolomé Torres Naharro, e da novela La Lozana andaluza (p. 208), provavelmente de autoria de Francisco Delicado, conforme as passagens na sequência:

Boreas. Y aun porque son tiranos,

que de nuestro largo afán

se retienen la moneda

debemos con dambas manos

recibir lo que no dan

y aun pedir lo que les queda. (Comedia Himenea, 1999, Jornada III) $)^{55}$

LOZANA. ¡Andá, que no en balde sois andaluz, que más ha de tres meses que en mi casa no se comió tal cosa! Vos, que sois guardarropa y tenéis mil cosas que yo deseo, y tan mísero sois ahora como antaño, ¿pensáis que ha de durar siempre? No seáis fiel a quien piensa que

\footnotetext{
${ }^{54}$ AQUINO, Santo Tomás de. Suma teológica, Parte IIa, Cuestión 161. Disponível em: http://hjg.com.ar/sumat/a/c116.html. 1994. Acesso em: 2 jul. 2012.

${ }^{55}$ TORRES NAHARRO, Bartolomé. Comedia Himenea. Disponível em:

http://www.cervantesvirtual.com/obra-visor/himenea--0/html/feea4ce6-82b1-11df- acc7-002185ce6064_3

.html. Acesso em: 12 ago. 2013.
} 
sois ladrón. ( La Lozana andaluza, 2004, Parte II, Mamotreto $X X V I I)^{56}$

Nessa configuração, tornam-se evidentes as relações de inimizade e desprezo em ambos os fragmentos. No primeiro, Boreas se queixa da tirania dos amos, cuja recusa pelo pagamento dos serviços faz com que esses criados tentem recebê-lo de qualquer maneira. Na obra seguinte, Lozana lamenta a fome que passa o personagem Guardarropa, censura-o por suas atitudes miseráveis, alertando-o de que sua situação pode vir a mudar; sendo assim, não deveria ser fiel a quem o considera um ladrão. Em outras palavras, em ambos os casos a deterioração da convivência entre amos e criados se apresenta de forma evidente.

Dessa maneira, torna-se compreensível a admiração sentida por Cipión diante da facilidade com que Berganza encontrava um amo a quem servir, muito embora não se possa pensar que essas questões socioeconômicas justifiquem as ações viciosas das personagens secundárias no "Coloquio". Mesmo assim, ao observar a censura de Cipión com respeito aos senhores da Terra, comparando-os com o Senhor do céu, Antonio Ríos $\operatorname{Rojas}^{57}$ afirma que

[...] esta novela concluye con la exposición de la sabiduría de la pobreza, oscurecida por la necesidad y la miseria, frente a la apariencia de las riquezas y de todas las obras salidas de ella. (RÍOS ROJAS, 2006, p. 9)

Retornando à narrativa de Berganza, o protagonista segue seu relato e utiliza-se das afirmações do amigo; faz uma espécie de "gancho" narrativo, dando início às suas explicações a partir do conceito de humildade. Utiliza como exemplo sua própria atitude na busca por um amo ou por uma casa que o acolha, conforme o fragmento abaixo:

\footnotetext{
56 DELICADO, Francisco. La Lozana andaluza. Disponível em: http://www.cervantesvirtual.com/obravisor/la-lozana-andaluza--1/html/00132f70-82b2-11df-acc7-002185ce6064_2.html/pdf. Acesso em: 12 ago. 2013.

57 RÍOS ROJAS, Antonio. Comentario al "Coloquio de los perros" de Cervantes. Disponível em: http://pendientedemigracion.ucm.es/info/especulo/numero32/coperros.html. Acesso em: 4 jul. 2012.
} 
BERGANZA. A lo que me preguntaste del orden que tenía para entrar con amo, digo que ya tú sabes que la humildad es la basa y fundamento de todas virtudes, y que sin ella no hay alguna que lo sea. Ella allana inconvenientes, vence dificultades y es un medio que siempre a gloriosos fines nos conduce; de los enemigos hace amigos, templa la cólera de los airados y menoscaba la arrogancia de los soberbios, es madre de la modestia y hermana de la templanza; en fin, con ella no pueden atravesar triunfo que les sea de provecho los vicios, porque su blandura y mansedumbre se embotan y despuntan las flechas de los pecados. (CERVANTES, 2005, p. 666)

O protagonista justifica sua facilidade em conseguir um amo a quem servir através de uma pequena digressão, cujo início se dá no instante em que faz uma apologia a respeito da humildade, tida pelo protagonista como base e fundamento de todas as virtudes. É curioso notar certa aproximação do discurso de Berganza com alguns preceitos contidos na Suma teológica de Santo Tomás de Aquino, Parte II, especificamente, na questão 161, no trecho em que o teólogo discorre sobre o conceito de humildade. Desse modo, para Tomás de Aquino a humildade "es el cimiento de todas las virtudes" (p. 522), pois, ao citar Santo Agostinho, conclui que se o homem pensa em construir um edifício muito alto, pensa primeiro no cimento da humildade (p. 522), ou seja, a humildade serve como base ou sustentação de todas as virtudes. É notável a semelhança entre o discurso de Tomás de Aquino com a afirmação do cão Berganza.

Retornando à Suma teológica, para Tomás de Aquino, a humildade, enquanto virtude, não obedece a critérios de importância espiritual, mas a um ajuste "psicomoral" do comportamento, pois refreia o ânimo para que não se deseje coisas altas, embora impulsione o homem a desejar as coisas conforme a reta razão, a qual está relacionada à magnanimidade (pp. 517-20). Ao citar Aristóteles, o teólogo considera que a humildade, 
como virtude específica, observa a sujeição do homem a Deus, cuja honra também se humilha, submetendo-se a outros e acrescenta :

[...] la humildad se ocupa propiamente de la reverencia por la que el hombre se somete a Dios. Por eso, todo hombre, en lo que es suyo, debe someterse a cualquiera que sea su prójimo en cuanto a lo que hay de Dios en éste. (AQUINO, 1994, p. 521)

Com base nesses preceitos, pode-se supor que Berganza faça uso da humildade como prova de submissão, com a finalidade de conseguir um amo a quem servir, provavelmente buscando nesse homem uma centelha de Deus. Em sua longa exposição, Berganza introduz um princípio religioso voltado ao enaltecimento dessa virtude, atribuindo-lhe a responsabilidade de uma série de transformações no que concerne às ações humanas, as quais irão possibilitar uma melhora moral, um fim virtuoso, visando um bem comum.

No entanto, na sequência o jovem mastim salienta:’[...] habiendo primero considerado y mirado muy bien ser casa que pudiese mantener y donde pudiese entrar un perro grande.” (CERVANTES, 2005, p. 666).

É oportuno notar que ao mesmo tempo que Berganza faz uma apologia à humildade, no instante seguinte assume uma postura voltada ao interesse, ou seja, a busca por um amo que pudesse mantê-lo. Em contrapartida, serviria esse amo fazendo uso de suas habilidades como cão de guarda. O que se pode pensar é que Berganza estabelece, por intermédio dessa digressão, a relação que manterá com esse novo amo, bem como o que espera que esse senhor lhe proporcione em termos de abrigo e alimento.

Por outro lado, desde o instante em que Berganza abraçou o ofício de "perro pastor", o protagonista faz referência aos pobres e humildes. A princípio com a missão de defendê-los dos poderosos e soberbos, agora serve-se da mesma condição, isto é, 
como pobre e simples, sustenta uma aparente humildade, com o propósito de conseguir um novo ofício, um novo amo, conforme o parágrafo abaixo:

BERGANZA. Luego arrimábame a la puerta y cuando, a mi parecer, entraba algún forastero, le ladraba, y cuando venía el señor bajaba la cabeza y, moviendo la cola, me iba a él y con la lengua le limpiaba los zapatos. Si me echaban a palos, sufríalos, y con la misma mansedumbre volvía a hacer halagos al que me apaleaba, que ningún segundaba viendo mi porfía y mi noble término. (CERVANTES, 2005, p. 666)

De fato, para conseguir a aceitação do novo senhor, Berganza não somente demonstra um profundo respeito e humildade, mas chega ao extremo da subserviência quando lhe lambe os sapatos. Assim, se por um lado o protagonista demonstra lealdade e fidelidade incondicionais, por outro suas ações não eram desinteressadas, pois havia a preocupação, por parte do personagem, de verificar se a casa comportava um cão de seu tamanho. Consequentemente, pode-se supor que, se a casa fosse simples e pobre, não sendo possível mantê-lo, em termos de abrigo e comida, Berganza provavelmente não se aproximasse do local.

Em outras palavras, Berganza oculta suas intenções, fazendo uso de ações humildes e até mesmo subservientes a fim de atingir seus objetivos. Com isso, é possível dizer que o protagonista, mediante as ações descritas, dissimula suas intenções nesse momento do "Coloquio", visando um bem comum, tanto para com seu novo amo quanto para si próprio. Como dirá mais adiante, Berganza se converteria “[...] en universal centinela de la mía y de las casas ajenas" em troca de um teto e de alimento.

Ademais, evidencia-se que o conceito de dissimulação a partir da obra de Torquato Accetto consiste, levando em conta os estudos modernos de Alcir Pécora, ${ }^{58}$ ao citar Rousset, em um "método para a pessoa se construir", ou "construir-se a partir de

\footnotetext{
${ }^{58}$ ACCETTO, Torquato. Dissimulação honesta. Martins Fontes: São Paulo, 2001.
} 
um modelo", contrariando uma postura hipócrita, pois está direcionando suas ações a um "ideal honesto de domínio, composição e apresentação de si” (p. XVIII). De outro modo,

[...]representa, nesta acepção, o mesmo que a discrição, cujo principal emprego está em ser o que quer parecer, e cujo empenho de indústria e cálculo deve ser entendido como "esclarecimento da virtude" e "flexibilidade" para acomodar-se à ocasião e aos "humores variáveis de cada um". (ACETTO, 2001, p. XVIII)

Para Pécora, Rousset associa a dissimulação ao teatro, à ostentação, fazendo com que se constitua como "uma poderosa arte de agradar", não se opondo com isso à naturalidade ou ao efeito de "não afetação" (p. XIX).

Sem dúvida, como esperado, Berganza é aceito na casa do rico comerciante, permanecendo amarrado de dia e solto à noite, tempo este em que o cão aproveita para percorrer todos os lugares possíveis:

BERGANZA. [...] servía con gran cuidado y diligencia; ladraba a los forasteros y gruñía a los que no eran muy conocidos; no dormía de noche, visitando los corrales, subiendo a los terrados, hecho universal centinela de la mía y de las casas ajenas. Agradose tanto mi amo de mi buen servicio, que mandó que me tratasen bien y me diesen ración de pan y los huesos que se levantasen o arrojasen de su mesa [...] a lo que yo me mostraba agradecido. (CERVANTES, 2005, p. 667)

Pode-se afirmar que esse parágrafo da novela remete ao já citado anteriormente com relação à postura dos jovens criados na Alta Idade Média. Como observado por Maravall, eram recebidos na casa dos senhores poderosos, alimentados e formados tanto nas armas, quanto nas letras, dispensando total fidelidade e agradecimento aos seus amos. No caso de Berganza, a princípio o alimentam, sendo responsável pela guarda e segurança da casa. Quanto ao que se refere às letras, se verá mais à frente. 
Como era diligente em seu ofício, Berganza consegue agradar tanto ao seu novo amo que o mesmo ordena aos criados que lhe dispensem bons tratos e boa comida.

BERGANZA. [...] yo me mostraba agradecido, dando infinitos saltos cuando veía a mí amo, especialmente cuando venía de fuera; que eran tantas las muestras de regocijo que daba y tantos los saltos, que mí amo ordenó que me desatasen y me dejasen andar suelto de día y de noche. (p. 667)

Diante dos cuidados recebidos e vendo-se livre, o protagonista demonstra seu contentamento:

BERGANZA. Como me vi suelto, corrí a él, rodeele todo, sin osar llegarle con las manos, acordándome de la fábula de Isopo ${ }^{59}$, cuando aquel asno, tan asno que quiso hacer a su señor las mismas caricias que le hacía una perrilla regalada suya, que le granjearon ser molido a palos. Pareciome que en esta fábula se nos dio a entender que las gracias y donaires de algunos no están bien en otros. (CERVANTES, 2005, pp. 667-8)

Na opinião de Berganza, apesar do grande contentamento, não deveria expressar qualquer demonstração de afeto para com seu amo ou ousar tocar-lhe, pois não seria adequado, levando em conta a pessoa do comerciante, bem como a relação servil do protagonista para com esse senhor. No entanto, o que Berganza quer advertir ou aconselhar com essa fábula? O que se pode extrair das afirmações do jovem mastim?

Para se entender tais questões, é oportuno primeiro recordar o significado de fábula no século XVII. Assim, como se leu páginas atrás, de acordo com o preceptista

\footnotetext{
${ }^{59}$ ESOPO, Fábulas. Barcelona: Gredos, 2008. Há uma certa variação com respeito a essa fábula, em comparação ao texto original: "Un hombre, que tenía un perro maltés y un burro, se pasaba el tiempo jugando continuamente con el perro. Y si alguna vez salía fuera a comer le traía alguna cosa y se la tiraba cuando el perro se le acercaba moviendo el rabo. El burro, lleno de envidia, corrió a su lado y poniéndose a hacer cabriolas, pegó una coz al amo. Éste, irritado, hizo que se llevaran el burro a palos y lo ataran al pesebre". La fábula muestra que no todos han nacido para lo mismo. (p. 43)
} 
Alonso López Pinciano ${ }^{60}$, em se tratando das fábulas de Esopo, podem ser compreendidas como ficção e mentira, mesmo que estabeleçam uma verdade, pois “debajo de una hablilla" apresentam um conselho sutil e verdadeiro (p. 175). Nesse aspecto, Berganza utiliza-se dessa fábula esópica para demonstrar os cuidados que um criado deve apresentar no trato com seu senhor, respeitando sempre a hierarquia que os separa, a fim de evitar constrangimentos mediante atos inconvenientes.

Conforme a pesquisadora Monique $\mathrm{Joly}^{61}$, em seus estudos modernos, ao comentar o uso cervantino da fábula de Esopo na novela exemplar "El coloquio de los perros”, observa que a alusão feita por Berganza a esse apólogo aproxima-se do livro II do El cortesano de Baldassare Castiglione, embora exista certa distinção entre a abordagem de Castiglione, feita através de Federico Fragoso, e a citada por Berganza. Na passagem de El cortesano, Fragoso comenta sobre a relação entre o príncipe e os cortesãos, afirmando que nem todos os que desejam prosperar conseguem entreter o príncipe com discrição. Ao citar a mesma fábula esópica, acrescenta: "Por isso é preciso que cada um conheça a si mesmo e suas forças, e a tanto se adapte, decidindo as coisas que pode imitar ou não.” (CASTIGLIONE, 1997, p. 107).

No entanto, as afirmações de Berganza se aplicam a um outro contexto, outro estamento social, pois faz referência ao comportamento de um criado para com seu senhor. Nesses termos, o protagonista segue em seu discurso e acrescenta:

BERGANZA. Apode el truhán, juegue de manos y voltee el histrión, rebuzne el pícaro, imite el canto de los pájaros y los diversos gestos y acciones de los animales y los hombres el hombre bajo que se hubiere dado a ello, y no lo quiera hacer el hombre principal, a quien ninguna habilidad déstas le puede dar crédito ni nombre honroso. (CERVANTES, 2005, p. 668)

60 PINCIANO, Alonso López. Philosophía antigua poética. Madrid: Biblioteca Castro, 1973. Obras Completas I.

61 JOLY, Monique. Rebuzne el pícaro: comentarios sobre el uso cervantino de una fábula de Esopo. Disponível em: http://cvc.cervantes.es/literatura/aih/pdf/08/aih_08_2_007.pdf. Acesso em: 5 mar. 2012. 
Desse modo, ao examinar o contexto que paralelamente se desenvolve, verificase que Berganza, segundo Joly, aproveita-se da fábula do asno e da cadelinha para introduzir, também, uma descrição sobre como devem ser os criados (p. 56). Para a pesquisadora, essa significativa mudança de sentido e de nível, com respeito à relação de obrigações dos criados, não é a que se expressa em Castiglione, cujo discurso menciona as práticas sociais de um cortesão a serviço de um príncipe, mas

[...] la que se ha convertido en tema de preocupación para cuantos observan la multiplicación de los que no tienen más solución que encontrar un amo a quien servir, en una sociedad en que ha crecido trágicamente el desempleo. (JOLY, 2007, p. 56)

Evidentemente, o tema do desemprego e das relações servis é abordado tanto por Monique Joly quanto por Maravall, tendo como "palco" a situação econômica e social da Espanha do século XVII. Uma problemática retratada por intermédio desse diálogo canino, no instante em que seu protagonista institui uma paródia de um tratado do século XVI, como é o caso do El cortesano de Castiglione.

Ainda sobre esse fragmento do "Coloquio", paralelamente aos estudos de Monique Joly com respeito à fábula de Esopo, Pablo Carranza, ${ }^{62}$ ao analisar a referida fábula nessa passagem da novela, citando Thomas Keenan, argumenta que uma das principais preocupações das fábulas de Esopo diz respeito à questão da identidade. Ao falar sobre uma delas, afirma que as fábulas em geral impõem "identidades sobre las cosas y luego les amonesta por no salir de esa identidad" (p. 7). Exemplifica sua afirmação ao narrar a fábula do corvo, da águia e do agricultor. Conta que um corvo, ao ver uma águia capturar um carneiro com as garras, sentindo muita inveja, tenta fazer o mesmo. Entretanto, sendo incapaz de sustentá-lo, até mesmo porque suas garras se

62 CARRANZA, Pablo. Cipión, Berganza y la tradición esópica. Disponível em: http:// cervantesvirtual.com/obra-visor/cervantes bulletin-of-the-cervantes-society. html. Acesso em: 31 out. 2013. 
enroscam na lã do animal, o corvo cai e é capturado por um agricultor. Este corta suas asas e o dá para seus filhos como brinquedo. Quando as crianças perguntam ao pai que tipo de ave era aquela, o agricultor responde: "Para mí, sólo es un cuervo; pero él, se cree águila." "Moraleja: Pon tu esfuerzo y dedicación en lo que realmente estás preparado, no en lo que no te corresponde.",63

Para Keenan, essa relação entre o sujeito e o nome, o conhecimento, a ação, o saber e o fazer articulam-se, pois, ao mencionar essa fábula, Berganza também demonstra que "uno no debe tratar de ser lo que no es" (p. 7). O burro, enciumado, tenta ser como a cadelinha e acaba por ferir ao seu amo. Da mesma maneira, certos personagens secundários do "Coloquio" são seres que se esquecem de que são humanos, atuando como verdadeiros animais, como é o caso dos açougueiros (p. 7).

Dessa forma, nesse subcapítulo Berganza apropria-se de códigos de conduta cortesãos a fim de atingir seus objetivos; faz de suas diretrizes um modelo, cujo mecanismo será adaptado à própria situação. A referência, evidentemente, produz o riso, visto que o leitor percebe o texto original, verifica as mudanças de contextos e compreende o quão disparatada é a situação.

Evidencia-se assim, a comicidade nessa passagem da novela que se institui justamente por meio da imitação burlesca, introduzida por Berganza. A referência de uma fábula esópica foi utilizada pelo protagonista na tentativa de censurar, mais uma vez, certas práticas da sociedade ao seu redor, tomando como exemplo a relação que estabelece com o comerciante sevilhano. O emprego de tais artifícios tem como finalidade não somente colocar em evidência determinadas condutas sociais, que por si só se convertem em algo ridículo, como também entreter um público discreto que,

${ }^{63}$ ESOPO, Fábulas. Disponível em: http://www.guiainfantil.com/articulos/ocio/cuentos-infantiles/elaguila-el-cuervo-y-el-pastor-fabula-de-esopo-para-ninos/ Acesso em: 4 nov. 2013. 
evidentemente, por possuir conhecimento suficiente desses tratados, reconhece a burla e diverte-se com seu riso contido e refinado. 


\title{
2. Berganza, a Companhia de Jesus e os reveses da fortuna
}

\author{
La contraria fortuna hace a los hombres \\ prudentes.
}

Mateo Alemán

Fundada por Ignacio de Loyola em 1540, a Companhia de Jesus tinha como missão defender e propagar a fé católica, imbuída não somente do propósito de salvar as almas dos mensageiros de Deus, como também de lutar, com a mesma intensidade, pela salvação das "almas dos próximos" "64. Essa propagação da fé se dava através de sermões, lições públicas, confissões, exercícios espirituais, ensinamento da doutrina cristã a jovens, atenção espiritual a doentes e prisioneiros, seja nos cárceres, seja nas galés. Assim, os membros da Companhia de Jesus eram vistos como "soldados de Dios que se ponían bajo la obediencia del romano pontífice para su servicio”. Em outros termos, esses religiosos eram percebidos secularmente como um exército "a serviço do papado e da recatolização, vinculados a partir da Igreja romana com a Monarquia Hispânica",65.

Na obra Los jesuítas en España y en el mundo hispánico, ${ }^{66}$ no capítulo que trata sobre o "Retrato del jesuíta", Javier Burrieza Sanchez afirma que, a princípio, o próprio nome "Companhia de Jesus" causou certa estranheza no meio eclesiástico, especialmente nas ordens menores como a dos frades descalços, pois percebiam na utilização do termo "companhia" certa presunção e arrogância, como se não fossem, da mesma forma, companheiros de Jesus, militando sob a mesma bandeira.

\footnotetext{
${ }^{64}$ BURRIEZA SÁNCHEZ, Javier. Misión de la Compañía de Jesús en el siglo de la Reforma. In: EGIDO, Teófanes (Org.). Los jesuitas en España y en el mundo hispánico. Madrid: Marcial Pons, Ediciones de Historia S.A., 2004.

65 Idem. La Compañía de Jesús y la defensa de la monarquía hispánica. Disponível em: http://digital.csic.es/bitstream/10261/15836/3/54.pdf. Acesso: em 15 jul. 2011.

${ }^{66}$ Idem. Los jesuitas en España y en el mundo hispánico. Madrid: Marcial Pons Historia, 2004.
} 
Mesmo com a aprovação da Santa Sede, Loyola reconhecia o difícil começo, embora seus membros percebessem na figura do Cristo "el fundador de sus inquietudes dentro de la Iglesia [...]", eliminando qualquer modelo terreno (pp. 29$30)$.

Outro aspecto a ser considerado diz respeito ao nome "jesuíta", que na época não era utilizado por Loyola para designar os membros do instituto. Isso se deve ao fato de o termo apresentar denominação negativa por significar "sacerdote hipócrita", aquele que possui uma santidade simulada, uma aparência que oculta o mal. Por essa razão, para o pesquisador, os membros da Companhia não eram chamados de "jesuítas", sempre intitulados como "os da Companhia", ou aqueles que vivem sob a obediência da Companhia, havendo documentos que se referem a eles como "filhos de Santo Ignácio" ou simplesmente "membros da Companhia de Jesus" (p. 29). Entretanto, nas primeiras comunidades cristãs o termo "jesuíta" era identificado como seguidor de Cristo. Com o tempo, apesar de todas essas polêmicas, os religiosos perceberam o caráter prático dessa denominação e acabaram, por fim, utilizando-a.

Dentre tantas controvérsias, a Companhia de Jesus, por intermédio da rígida orientação das práticas religiosas, convertia-se em um exército a serviço do papado, da Contrarreforma, trabalhando pelo resgate de valores católicos. Conforme Burrieza, o ordenamento religioso se unia com o político e com o social, uniformizando as condutas,

[...] gracias a los rituales y símbolos que servían para igualar al Estado u a la Iglesia. Todo ello sucedía en una sociedad sacralizada donde el poder político y el religioso compartían objetivos y horizontes. (BURRIEZA SANCHEZ, 2008, p. 183) ${ }^{67}$

\footnotetext{
67 BURRIEZA SÁNCHEZ, Javier. La Compañía de Jesús y la defensa de la monarquía hispánica. Disponível em: http://digital.csic.es/bitstream/10261/15836/3/54.pdf. Acesso em: 15 jul. 2011.
} 
Com respeito ao trabalho educativo, a Companhia de Jesus estendeu seus colégios por todos os lugares, alcançando prestígio social, embora possa se pensar que essa educação venha reforçar a desigualdade social, ou seja, não era ministrada do mesmo modo para todos: levava em conta o estamento social a que pertencia o aluno. Até mesmo os sermões perseguiam, muitas vezes, interesses políticos, visando orientar a vida cotidiana da corte. Nesse sentido, para Burrieza Sanchez

[...] la denuncia de los pecados de los grandes desde el púlpito se convirtió en asunto de debate dentro de la Compañía de Jesús, originando ciertas consultas, [...] cuando indicaba que algunos sermones de la Compañía encubrían en demasía los errores de los grandes. (p. 197)

Por essa razão, estudar em um colégio da Companhia significava, evidentemente, um reconhecimento social; até mesmo porque para alguns homens pertencentes a determinados ofícios, como era o caso do amo de Berganza, isso lhe renderia certo prestígio frente à opinião alheia.

Prestígio que o rico comerciante lograva por intermédio de seus dois filhos: o mais jovem com doze e o mais velho com catorze anos. Os meninos estudavam gramática em um dos colégios da Companhia de Jesus. Berganza, admirado, descreve o quão surpreendente era observá-los sendo conduzidos aos estudos, com toda a pompa como se fossem filhos de algum nobre, conforme o parágrafo abaixo:

BERGANZA. Iban con autoridad, con ayo y con pajes, que les llevaban los libros y aquel que llaman vademécum. El verlos ir con tanto aparato, en sillas si hacía sol, en coche si llovía, me hizo considerar y reparar en la mucha llaneza con que su padre iba a la Lonja a negociar sus negocios, porque no llevaba otro criado que un negro, y algunas veces se desmandaba a ir en un machuelo aún no bien aderezado. (CERVANTES, 2005, p. 669) 
Diante de tal descrição, Berganza estabelece um comparativo entre a forma como os filhos do comerciante eram conduzidos ao colégio, com toda suntuosidade e ostentação, e a maneira simples e até mesmo humilde com que o pai se dirigia à "la Lonja" fazer seus negócios. Diante das descrições do amigo, Cipión faz a seguinte observação:

CIPIÓN. Has de saber, Berganza, que es costumbre y condición de los mercaderes de Sevilla, y aun de las otras ciudades, mostrar su autoridad y riqueza, no en sus personas, sino en las de sus hijos; porque los mercaderes son mayores en su sombra que en sí mismos. [...] y, como la ambición y la riqueza muere por manifestarse, revientan por sus hijos, y así los tratan y autorizan como si fuesen hijos de algún príncipe; y algunos hay que les procuran títulos, y ponerles en el pecho la marca que tanto distingue la gente principal de la plebeya. (CERVANTES, 2005, p. 669)

Nesse sentido, conforme as afirmações de Cipión, os comerciantes tinham por costume representar suas riquezas por intermédio dos filhos, um sinal de distinção social muito comum no século XVII. Entretanto, os comerciantes, nesse período, eram malvistos socialmente em função de serem em sua maioria de origem judaica, associados ao empréstimo de dinheiro, tidos como pessoas que procuram alcançar alguma posição dentro dessa ordem social, sem se preocuparem com os meios que utilizam para tal fim. Nessa configuração, ao analisar essa passagem do "Coloquio", Antony Close diz que (p. 65), em Sevilha, eram frequentes os comerciantes conversos (descendentes de judeus convertidos ao catolicismo) na busca por um título de nobreza, causando certa apreensão na velha aristocracia. Para o pesquisador, Cervantes usa de certa moderação nesse momento da novela, ao ignorar tal filiação judia, considerando 
[...] la espartana sobriedad de los comerciantes sevillanos, en contraste con su dispendioso trato con sus hijos, como un curioso fenómeno social en sí mismo, para resaltar, de forma excepcional, el aspecto potencialmente positivo de su ambición en lugar de una interpretación más cínica de la misma. (CLOSE, 2007, p. 65)

No entanto, esse episódio do "Coloquio" não estabelece somente uma alusão a El cortesano de Castiglione, como mencionado, mas aproxima-se também de alguns preceitos contidos no Galateo español de Lucas Gracián Dantisco, no instante em que os personagens comentam o aumento de pessoas da plebe com "títulos de ilustres", usados por nobres de nascimento que agora andam foragidos e exilados de sua antiga pátria. Para o escritor espanhol,

[...] viendo esto la nobleza de caballeros y gente calificada, se han aprovechado de subirse un grado o dos más arriba, para poderse diferenciar, especialmente en las cartas, de esta generación robadora de sus ilustres títulos. (DANTISCO, 1943, p. 61)

De fato, adquirir títulos de nobreza e ostentar por intermédio dos filhos uma posição social não condizente à sua real condição são aspectos que retratam aqueles que vivem e procuram desfrutar das falsas aparências. Nesses termos, mesmo respeitando a hierarquia própria dessa sociedade corporativa, há certos amos que acabam direcionando suas ações no sentido de representarem aquilo que não são, como é o caso do rico comerciante.

Para Berganza era ambição, mas ambição generosa, "[...] la de aquel que pretende mejorar su estado sin perjuicio de tercero." (CERVANTES, 2005, p. 670). Embora, na opinião de Cipión, "Pocas o ninguna vez se cumple con la ambición que no sea con daño de tercero.” (CERVANTES, 2005, p. 670).

Evidentemente, a afirmação do interlocutor expressa certa reserva com respeito às atitudes do amo de Berganza, talvez levando em conta o ofício do comerciante, pois, 
como já citado, esses homens eram malvistos pela sociedade, por causa de seus negócios ilícitos. Apesar de não concordar com a resposta do amigo, Berganza segue sua narrativa e comenta sobre os acontecimentos que o levaram a frequentar um colégio da Companhia de Jesus.

BERGANZA. Y así, digo que los hijos de mi amo se dejaron un día un cartapacio en el patio donde yo a la sazón estaba; y como estaba enseñado a llevar la esportilla del jifero mi amo, así del vademécum y fuime tras ellos, con intención de no soltalle hasta el estudio. (CERVANTES, 2005, p. 671)

Quando os jovens amos viram Berganza com o vade-mécum, solicitaram a um pajem que o retirasse da boca do cão. No entanto, Berganza não o soltou, e entrou na sala de aula com o objeto na boca, ação que causou riso em todos os estudantes.

BERGANZA. Llegueme al mayor de mis amos, y, a mi parecer con mucha crianza, se le puse en las manos, y quedeme sentado en cuclillas $[\ldots]$ mirando de hito en hito al maestro que en la cátedra leía. (CERVANTES, 2005, p. 672)

Verifica-se assim, a maneira com que Berganza se apresenta em sala de aula, portando-se com muita educação e respeito. Afinal, o protagonista estava em um centro de saberes, em um colégio da Companhia de Jesus, o que o conduz a estar de acordo com a ocasião, o lugar, as pessoas presentes. Além disso, o protagonista não consegue deixar de observar a atitude do professor para com os alunos, ações "ternas" direcionadas a conduzir os jovens pelos caminhos da virtude, conforme o parágrafo a seguir:

BERGANZA. No sé qué tiene la virtud, que, con alcanzárseme a mí tan poco o nada della, luego recibí gusto de ver el amor, el término, la solicitud y la industria con que aquellos benditos padres y maestros enseñaban a aquellos niños, enderezando las tiernas varas de su juventud, porque no torciesen ni tomasen mal siniestro en el camino 
de la virtud, que junto con las letras mostraban. (CERVANTES, 2005, p. 672)

Nesse parágrafo, fica evidente a ironia da personagem com relação ao tratamento dispensado pelos mestres do colégio para com os alunos, a fim de que não seguissem pelo caminho do mal. Nesse sentido, ensinamentos e castigos eram aplicados aos jovens: letras e surras com "las tiernas varas", apesar dessas ações terem como propósito conduzi-los por caminhos do bem. Para Berganza, que no início do parágrafo se coloca na posição de cão ou animal irracional, a virtude algumas vezes o alcança, outras não, mas mesmo assim não deixa de notar o esforço dos padres no sentido de passá-la aos meninos.

Dessa maneira, por intermédio da aplicação de ensinamentos e castigos exemplares, de acordo com João A. Hansen, em seu artigo Educando príncipes no espelho $^{68}$, os religiosos retomavam a ideia aristotélica de que "as artes corrigem a natureza, pois a alma humana pode ser melhorada pela instrução [...] e pela formação de costumes e hábitos cristãos” ( p. 75).

Ademais, os ensinamentos aplicados pelos jesuítas da Companhia geralmente abordavam temas doutrinários provenientes dos espelhos de príncipes. Compreendidos como tratados originários da Idade Média, os espelhos de príncipes apresentavam uma matéria didática destinada a orientar a formação educacional de jovens príncipes, bem como de crianças cortesãs. Nesse aspecto, para uma melhor compreensão da importância desses tratados na educação aplicada não somente pela Companhia, como também nas academias, instituições e ordens religiosas daquele período, é importante observar que esse gênero didático, segundo Hansen, foi muito difundido a partir do século XVI (p. 63). Seus ensinamentos, distribuídos em um conjunto de diretrizes

\footnotetext{
${ }^{68}$ HANSEN, João A. Educando príncipes no espelho: Os intelectuais na história da infância. In: FREITAS, Marco Cezar de; Kuhlmann Jr. Moysés (Org.). São Paulo: Cortez, 2002.
} 
voltadas a aspectos políticos e morais, estavam destinados a conduzir e orientar a formação do futuro rei cristão. Por essa razão, conforme o pesquisador, esses tratados eram percebidos, em sentido figurado, como verdadeiros espelhos, que, ao serem mirados, direcionavam os passos desse monarca. Com fundamentos pautados na metafísica cristã, escolástica e neoescolástica, seus autores adaptavam “padrões antigos, gregos, latinos, patrísticos e medievais à centralização monárquica dos séculos XVI e XVII" (HANSEN, 2006, pp. 62-3).

Para Hansen, essa centralização monárquica se deu por intermédio da transformação da antiga nobreza de armas em nobreza de letras, "civilizada e erudita", subordinada a "um rei e uma corte" (p. 63). Assim, o poder guerreiro cede lugar ao poder das letras; recebe uma educação ministrada principalmente por colégios jesuítas, cujo objetivo está em instituir um dispositivo que "naturaliza a desigualdade social" (p. 63). Nesse aspecto, para o pesquisador, essa desigualdade social constitui a infância por intermédio de uma educação e formação em que duas categorias intelectuais, a discrição e a vulgaridade, irão separar as crianças nobres das crianças do povo. Essas categorias intelectuais serão apropriadas pela sociedade como modelo de representação, mediante uma educação dirigida igualmente para todos, segundo os autores dos espelhos, apesar de que a nobreza possua "naturalmente" maiores recursos para conseguir uma vida virtuosa (p. 64).

Dessa forma, a doutrina contida nos espelhos regulamenta que a educação deve conduzir os indivíduos que a recebem a uma "integração harmoniosa" como súditos pertencentes ao mesmo corpo político do Estado. Em outras palavras, "a liberdade de cada indivíduo é definida como subordinação à cabeça real” (p. 66). Para tal fim, a Companhia de Jesus ensinava, antes de tudo, o autocontrole, visando a justa medida das paixões e a amizade com o restante do corpo político. 
Entretanto, apesar desses ensinamentos serem passados aos jovens por intermédio de "las tiernas varas", as crianças nobres recebiam outros tratamentos, diferenciando-se das crianças tidas como vulgares, pois, a esse respeito,’[...] o "desacato" da repreensão e do castigo atuam para corrigir com violência o que pais e mestres constituem negativamente como fragilidade infantil." (HANSEN, 2006, p. 88).

Ao citar o mestre-escola de Valência, Lorenço Palmyreno, Hansen acrescenta que as crianças aldeãs, por exemplo, eram tratadas com rusticidade pelos mestres, no momento em que aplicavam castigos violentos, chegando até a deformar seus pequenos corpos. No entanto, Palmyreno propõe que os mestres sejam "tratados com respeito" para que possam aplicar uma boa educação a crianças aldeãs, a fim de que consigam desempenhar bem seus ofícios na cidade (p. 90).

Em outros termos, as ações se justificam, pois tinham como objetivo converter essas crianças em seres virtuosos, a fim de transformá-las em bons serviçais. Nesse aspecto, Hansen conclui que:

A razão da virtude é imediatamente prática, no caso, pouco tendo a ver com os elevadíssimos fins últimos do homem a que a virtude sempre se associa nos espelhos de príncipes. (HANSEN, 2006, p. 90)

Nessa configuração, retornando ao "Coloquio", Berganza compreendia que todos esses castigos tinham como propósito dirigir os homens e corrigi-los, pois

BERGANZA. Consideraba cómo los reñían con suavidad, los castigaba con misericordia, los animaban con ejemplos, los incitaban con premios y los sobrellevaban con cordura; y, finalmente, cómo les pintaban la fealdad y horror de los vicios e les dibujaban la hermosura de las virtudes, para que, aborrecidos ellos y amadas ellas, consiguiesen el fin para que fueron criados. (CERVANTES, 2005, 672) 
O fragmento enaltece a educação como meio de se alcançar uma vida virtuosa, longe dos pecados e das tentações. Para isso, os castigos eram aplicados com misericórdia pelos mestres. No entanto, as afirmações de Berganza não deixam de conter certa ironia, tendo em vista a maneira como esses castigos eram infligidos, ou seja, por intermédio de "las tiernas varas". Como práticas didáticas, os castigos visavam formar um ser virtuoso, que convivesse em harmonia com seus semelhantes.

Nessa configuração, pode-se estabelecer uma possível analogia entre esse contexto, apresentado pelo protagonista, com a ordem política vigente. Isso posto, ao recordar a política católica dos séculos XVI e XVII, o estado era visto pela metáfora de um corpo político composto por ordens e estamentos, que se subordinavam à cabeça, ou seja, à figura do rei. Nesse aspecto, corpo e membros deveriam conviver de maneira harmoniosa, subordinados com resignação a esse monarca, o que efetivamente não ocorria, conforme se verá mais adiante. Guardadas as devidas proporções, da mesma maneira, as crianças conviviam com harmonia, respeitando a hierarquia com subordinação, tudo com vistas a um bem comum. $\mathrm{O}$ que nos conduz a pressupor que Berganza aplica as diretrizes da política católica à própria situação.

Diante das afirmações do amigo, Cipión declara:

CIPIÓN. Muy bien dices, Berganza; porque yo he oído decir desa bendita gente que para repúblicos del mundo no los hay tan prudentes en todo él, y para guiadores y adalides del camino del cielo, pocos les llegan. Son espejos donde se mira la honestidad, la católica doctrina, la singular prudencia, y, finalmente, la humildad profunda, base sobre quien se levanta todo el edificio de la bienaventuranza. (CERVANTES, 2005, p. 672)

Igualmente, Cipión não deixa de admirar as ações ternas desses tão diligentes mestres, no momento em que o protagonista elogia tanto os ensinamentos quanto as repreensões e castigos aplicados. Nesses termos, os padres são descritos como seres 
prudentes, detentores de uma profunda humildade. A frase mais uma vez aproxima-se das afirmações de Santo Agostinho, o qual percebe a humildade como base onde se ergue o edifício da bem-aventurança.

Ao mesmo tempo, a expressão "repúblicos del mundo" é utilizada por Cipión ao referir-se aos padres e pedagogos, relacionando-os àqueles que cultivam a virtude, a qual conduz os homens a um bem comum. ${ }^{69}$ No entanto, a mesma expressão pode apresentar outro sentido válido, pois estabelece uma relação de analogia com a sentença: "locos repúblicos y de gobierno", frase utilizada no século XVII para referendar, de maneira pejorativa, a figura do arbitrista. ${ }^{70}$ Considerado de forma depreciativa na época de Cervantes, o arbitrista era um indivíduo que arquitetava planos extraordinários para alcançar determinados fins, personagem muito satirizado nos textos do período $^{71}$. Cabe lembrar que, no episódio dos quatro enfermos, no final da novela, um dos personagens era arbitrista; dentre seus "planos extravagantes" estava uma solução para as dívidas do rei da Espanha, em troca de favores, conforme o fragmento abaixo:

“[...] hase de pedir en Cortes que todos los vasallos de Su Majestad, desde edad de catorce a sesenta años, sean obligados a ayunar una vez en el mes a pan y agua, [...] y que todo el gasto que en otros condumios de fruta, carne y pescado, vino, huevos y legumbres, que han de gastar aquel día, se reduzga a dinero y se dé a Su Majestad [...] y con esto, en veinte años queda libre de socaliñas y desempeñado. Porque si se hace la cuenta, [...] bien hay en España más de tres

\footnotetext{
${ }^{69}$ CERVANTES, Miguel de. Novelas Ejemplares: "El Coloquio de los perros". Barcelona: Crítica, 2005. Nota de rodapé p. 672.

${ }^{70}$ arbitrium, albedrío, segundo Covarrubias: "Arbitrista es quien dirige un memorial al rey solicitándole que tome tal o cual arbitrio. La producción escrita memorialística sufrió una inflación comparable a la que se estaba dando en la economía real durante la revolución de los precios del siglo XVI y se incrementó con la crisis del siglo XVII, en una coyuntura económica depresiva". Arbitrismo - Conceito histórico y valoración. Disponível em: http://es.wikipedia.org/wiki/Arbitrista. Acesso em: 25 jul. 2011.

${ }^{71}$ SÁNCHEZ MOLLEDO, José María. Arbitristas aragoneses de los siglos XVI y XVII - Textos. Zaragoza: Institución "Fernando el Católico", 2009. "El Antecristo ha de ser arbitrista. A todos os he de quemar vivos y guardar vuestra ceniza para hacer de ella cernada y colar las manchas de todas las repúblicas. Los príncipes pueden ser pobres; mas entrando en arbitristas, para dejar de ser pobres, dejan de ser príncipes.” QUEVEDO, La fortuna con seso. p. 15.
} 
millones de personas de la dicha edad, fuera de los enfermos, más viejos o más muchachos, y ninguno déstos dejará de gastar, y esto contado al menorete, cada día real y medio; y yo quiero que sea no más de un real, que no puede ser menos, aunque coma alholvas. (CERVANTES, 2005, pp. 733-4)

A esse respeito, fica evidente a censura aos arbitristas, ridicularizados não somente pelos planos "mirabolantes" que faziam, mas por ações que comprometiam um juízo moral. Daí a provável associação desses indivíduos com os padres pedagogos, feita pelo protagonista.

É oportuno ressaltar que na novela Berganza e Cipión descrevem padrões de conduta que transitam entre o fingimento e a virtude moral. Essa imagem se estabelece por toda a obra, tanto através do diálogo instituído pelos protagonistas quanto por intermédio das práticas descritas das demais personagens. No entanto, segundo Close, essas censuras que povoam a novela, apesar de serem muitas, limitam-se a um pequeno grupo composto por gente vil, charlatães e oficiais corruptos; até os mestres da Companhia não escapam da censura canina. Desse modo, se em determinada situação os protagonistas escandalizam-se com os abusos evidentes, em outra divertem-se com suas "excentricidades" $"$. Daí os cães terem a capacidade de analisar os dois lados de um acontecimento, redimindo os mesmos indivíduos que censuram (CLOSE, 2006, p. 64).

Retomando a narrativa de Berganza, seus jovens amos gostaram tanto da iniciativa do cão de levar "el vademécum" que decidiram ser esta uma prática habitual. Assim, Berganza tirava proveito de sua permanência no colégio, divertindo-se com as outras crianças:

BERGANZA. Arrojaban los bonetes o sombreros, y yo se los volvía a la mano limpiamente. [...] Dieron a darme de comer [...] y gustaban de

\footnotetext{
${ }^{72}$ CLOSE, Antony. Cervantes y la mentalidad cómica de su tiempo. Madrid: Ed. Centro de Estudios Cervantinos, 2006. Disponível em: http://books.google.com/books HTML, s/d 79827 bytes. Acesso em: 8 jun. 2011.
} 
ver que, cuando me daban nueces o avellana, las partía como mona, dejando las cáscaras y comiendo lo tierno. [...] Finalmente, yo pasaba una vida de estudiante sin hambre y sin sarna, que es lo más que se puede encarecer para decir que era buena; porque si la sarna y el hambre no fuesen tan unas con los estudiantes, en las vidas no habría otra de más gusto y pasatiempo, porque corren parejas en ella la virtud y el gusto, y se pasa la mocedad aprendiendo y holgándose. (CERVANTES, 2005, p. 673)

Dessa forma, as crianças aproveitavam a meia hora que há de uma lição a outra não para repassá-las, mas para divertir-se com o diligente mastim. Descontentes, os mestres ordenam que os jovens amos não o levem mais à escola.

BERGANZA. Desta gloria y desta quietud me vino a quitar una señora que, a mi parecer, llaman por ahí razón de estado; que, cuando con ella se cumple, se ha de descumplir con otras razones muchas. [...] así, ordenaron a mis amos que no me llevasen más al estudio. Obedecieron, volviéronme a casa y a la antigua guarda de la puerta. (CERVANTES, 2005, pp. 673-4)

Para compreender a afirmação de Berganza, deve-se verificar atentamente o que se entende pela expressão razão de Estado no século XVII. Compreendida como sendo um conjunto de medidas utilizadas pelo poder monárquico absolutista, visando o bem comum, essas medidas garantiam a ordem e a harmonia do corpo político do Estado, apesar de que por meio dessas ações, segundo Hansen, ${ }^{73}$ o poder absoluto "transgredia o direito" (p. 136). Em outras palavras, de acordo com o pesquisador, a razão de Estado garantia a manutenção da ordem e da harmonia do corpo político, contra inimigos externos, visando sempre o bem de todo esse corpo, composto por ordens e estamentos.

Ao observar a obra Della ragio di Stato (1588), escrita pelo jesuíta Giovanni Botero, percebe-se que sua formulação, aos moldes dos Espelhos de príncipes, institui

\footnotetext{
${ }^{73}$ HANSEN, João A. Razão de Estado. In: NOVAES, Adauto (Org.). A crise da razão. São Paulo: Cia. das Letras, 2006.
} 
conselhos éticos e políticos com vistas a formar o futuro monarca, cujas virtudes irão transitar entre as armas e a cultura letrada (p. 141). As versões neoescolásticas irão propor, ainda, a "verdadeira razão de Estado", baseada em virtudes cristãs, "constituindo outras codificações rivais do poder como "irracionalidade", “excepcionalidade", "imoralidade" e "falsidade" (p. 136). Dessa forma, para Hansen,

[...] Botero pressupõe o modelo de uma corte [...] que centraliza o poder e que simultaneamente é difundido para todas as ordens políticas do reino como padrão de excelência humana. A tríade cortesã "discrição, prudência e paciência" [...] se torna fundamental na política do XVII [...], especifica o tipo do príncipe perfeito [...]. Distinções especiosas de sagrado e profano, de puro e impuro, de bastardo e legítimo modulam os exemplos de acordo com virtudes, conveniências e decoros. (HANSEN, 2006, p. 137)

Além disso, na razão de Estado existe uma virtude que se destaca de todas: a obediência (p. 143). Essa obediência se constitui como atributo dos súditos, no instante em que recebem o poder de Deus e o transferem para o rei, instituindo o que se entende por pacto de sujeição. Nesse contexto, para Hansen, se estabelece que toda iniciativa individual ou grupal contra essa razão de Estado seja definida como um ato de blasfêmia ou heresia, devendo ser coibida. Ademais, por não poder ordenar a si mesmo, o rei se encontra acima da lei, livre da força coerciva dessa lei, embora concomitantemente esteja "subordinado a ela por sua força de direção" (p. 144). Nessa configuração, é importante verificar as afirmações de Francisco Suárez, jesuíta, filósofo, pensador e jurista dos séculos XVI e XVII, em seu tratado De Legibus $^{74}$ (1612), a respeito do tema:

\footnotetext{
${ }^{74}$ SUÁREZ, Francisco. De legibus. Disponível em: http://www.cepc.gob.es/publicaciones/libros/colecciones?txtBusquedaSimple=francisco $\% 20$ su\%C3\%A1r ez\&rqIDC=158 pdf. Acesso em: 25 nov. 2013.
} 
Hay, finalmente una razón de principio que ya tocó Santo Tomás, y es que ningún cuerpo puede conservarse si no hay algún principio al cual le corresponda procurar y buscar el bien común del cuerpo. Esto es claro en el cuerpo natural, y lo mismo enseña la experiencia tratándose del cuerpo político. (SUÁREZ, III, 5, 1, p. 198)

Ainda perseguindo esse tema, convém salientar que a obra Razão de Estado de Giovanni Botero era lida nos cursos de Direito da Universidade de Coimbra, bem como divulgada pelos jesuítas nos colégios da Companhia de Jesus, a fim de “doutrinar o poder da política católica" (HANSEN, 2006, p. 140).

Por esse motivo, retornando ao texto do "Coloquio", a ordem para que Berganza não frequentasse as aulas do colégio era vista pelo protagonista como uma espécie de razão de Estado adequada àquela situação, pois visava acima de tudo o bem dos estudantes, a concórdia desses com seus mestres, enfim, a harmonia de todos. A ironia do protagonista é percebida no instante em que observa que "cuando con ella se cumple, se ha de descumplir con otras razones muchas". Nesse caso, ao ser imposta essa pretensa razão de Estado, serão descumpridos outros direitos, pois até o favor concedido pelo comerciante à Berganza, no sentido de o cão permanecer solto pela casa durante todo o tempo, será esquecido. Como resultado, o mastim, agora, permanece preso pela corrente, restrito à velha esteira detrás da porta. Com muita tristeza, Berganza relata seus infortúnios ao amigo:

BERGANZA. [...] cuando las miserias y desdichas tienen larga la corriente y son continuas, o se acaban presto, con la muerte, o la continuación dellas hace un hábito y costumbre en padecellas, que suele en su mayor rigor servir de alivio; mas, cuando de la suerte desdichada y calamitosa, sin pensarlo y de improviso, se sale a gozar de otra suerte próspera, venturosa y alegre, y de allí a poco se vuelve a padecer la suerte primera y a los primeros trabajos y desdichas, es un dolor tan riguroso que si no acaba la vida, es por atormentarla más viviendo. (CERVANTES, 2005, p. 674) 
Conforme uma antiga tópica contida nas obras La consolación de la filosofía ${ }^{75}$, de Boécio (480-524/525 d.C.) e na Divina comédia de Dante (1265-1321), a recordação de um tempo feliz é o maior dos males quando se está em uma situação miserável. Fazendo uma pequena explanação com relação às obras citadas, a começar pela de Boécio, ${ }^{76}$ seu surgimento se deu durante o tempo em que o filólogo permaneceu prisioneiro em Pávia, aguardando a execução da pena de morte. Desesperado, Boécio lamenta sua sorte, questionando a existência da justiça, especialmente a Divina. Na obra, repleta de alusões a textos poéticos e filosóficos ${ }^{77}$, Boécio ensina que "la única cultura fértil, oral o escrita, es la que llevamos en nosotros mismos a cuyas palabras se convierten en fuentes vivas ante la adversidad".

No caso de Berganza, o cão não somente voltou a se encontrar preso às correntes, como também viu serem trocadas as "guloseimas" que os estudantes lhe forneciam pela mísera "ración perruna".

BERGANZA. Digo, en fin, que volví a mi ración perruna y a los huesos que una negra de casa me arrojaba, y aun éstos me dezmaban dos gatos romanos, que, como sueltos y ligeros, érales fácil quitarme lo que no caía debajo del distrito que alcanzaba mi cadena. (p. 674)

De fato, a vida de Berganza sofrera algumas transformações, as quais despertavam no protagonista um profundo descontentamento. No entanto, mais uma vez

\footnotetext{
${ }_{76}^{75}$ CERVANTES, Miguel de. Novelas Ejemplares. Madrid: Espasa-Calpe, 2011. p. 262.

76 BOECIO, La consolación de la filosofía. Madrid: Akal, 1997. p. 29. Disponível em: http://books.google.com.br/books?id=NT4VEaZA5Z0C\&printsec=frontcover\&hl=ptBR\&source=gbs_ge_summary_r\&cad=0\#v=onepage\&q\&f=false. Acesso em: 2 dez. 2013.

77 Vale a pena verificar as aproximações dessa passagem do "Coloquio" com os discursos tanto de Boécio quanto os contidos na Divina comédia de Dante, conforme os fragmentos abaixo: "De hecho, se alguna ocasión o de manera excepcional se produce la estabilidad de una situación fortuita, con todo, el último día de vida es como una especie de muerte, para la Fortuna que ha permanecido tan estable.¿ Crees acaso que hay alguna diferencia si eres tú quien la abandonas al morir o si es ella quien te abandona huyendo de ti??" (BOECIO, Libro II, p. 147)

"Ao ouvir esse lamento, baixei o rosto, e permaneci assim, até Virgílio me despertar. Voltei novamente àquele casal, e perguntei: - Francesca, o teu martírio me traz lágrimas aos olhos, mas dize-me, como permitiu o amor que tomásseis conhecimento de vosso sentimento recíproco? - Não há maior dor que lembrar da felicidade passada - disse ela -, mas se teu grande desejo é saber, te direi como quem chora e fala." (DANTE ALIGHIERI, 1999, Inferno, Canto V)
} 
no "Coloquio", será instituída uma quebra no tom desse discurso, convertendo aquilo que poderia ser desanimador em algo cômico e divertido, como se verá à continuação, no próximo subcapítulo.

O que se supõe nesse momento da novela é que Berganza constrói, por intermédio da própria narrativa, uma espécie de "espelho de príncipes" às avessas, abordando questões de caráter moral e político, que serão aplicadas na convivência que o protagonista estabelece na casa do rico comerciante. Ademais, ao descrever sua permanência na escola da Companhia de Jesus, o personagem expõe não somente diretrizes voltadas ao enaltecimento de virtudes cristãs instituídas pelos mestres religiosos, como também de que maneira essas virtudes eram ensinadas, ou seja, baixo repreensões e castigos exemplares, descrevendo a fealdade de determinadas práticas. Dessa forma, os ensinamentos eram propagados pela Companhia com o propósito de instituir determinados valores morais em todos os alunos e até mesmo em Berganza. Todas essas ações tinham também como propósito orientar uma convivência harmoniosa, seja no interior do colégio, seja com respeito à sociedade em que se inserem. 


\section{A pretensa filosofia de Berganza e sua relação com os escravos da casa}

Todos los crímenes y los vicios tienen como origen la debilidad; por ello no merecen más que compasión.

Alfredo de Vigny

A passagem de um estado feliz a um infeliz ou desgraçado comumente faz parte da existência humana. As mudanças na sorte, o girar da roda da fortuna sempre perseguem pessoas reais, bem como seres ficcionais. Berganza não seria uma exceção.

Assim, ao se pensar em um ser virtuoso, segundo Pinciano, ${ }^{78}$ baseando-se na Ética à Nicômaco de Aristóteles, o mesmo enfrenta as adversidades, tais como: a pobreza, a afronta, a enfermidade e outros males desta vida, com força e inteireza. Além disso, sabendo que não há miséria tão grande que o tempo não a amanse e lhe faça fácil, espera que depois da tormenta venha a bonança. Se as coisas não mudarem, basta pensar que a vida é breve e que o prêmio por sua virtude virá algum dia seja pela força segundo a ordem da terra, seja através da justiça dos céus (p. 21 a 22).

O fato é que Berganza, após sofrer os infortúnios provenientes da aplicação daquilo que intitulou de "razão de Estado" dos mestres da Companhia de Jesus, sentiase infeliz, pois não poderia mais frequentar o colégio junto com seus jovens amos. Diante de tantas desventuras, Berganza pede licença a Cipión, no sentido de que possa “filosofar un poco", ou seja, dizer coisas que lhe vinham à memória:

BERGANZA. Cipión hermano, así el cielo te conceda el bien que deseas, que, sin que te enfades, me dejes ahora filosofar un poco; porque si dejase de decir las cosas que en este instante me han venido

\footnotetext{
${ }^{78}$ LÓPEZ PINCIANO, Alonso. Philosophia antigua poética. Madrid: Biblioteca Castro.
} 
a la memoria de aquellas que entonces me ocurrieron, me parece que no sería mi historia cabal ni de fruto. (CERVANTES, 2005, p. 675)

Conforme o fragmento acima, Berganza utiliza o verbo "filosofar" para introduzir uma pequena digressão em seu discurso, embora Cipión desconfie de que se trata de alguma maledicência, como tantas já ditas pelo protagonista desde o início de suas reminiscências. Por esse motivo, o personagem o adverte, conforme o parágrafo abaixo:

CIPIÓN. [...] porque no tiene la murmuración mejor velo para paliar y encubrir su maldad disoluta que darse a entender el murmurador que todo cuanto dice son sentencias de filósofos, y que el decir mal es reprehensión y el descubrir los defectos ajenos buen celo. [...] Y debajo de saber esto, filosofea ahora cuanto quisieres. (CERVANTES, 2005, p. 675)

Certamente, Cipión adverte Berganza a respeito de algumas facetas que a murmuração assume a fim de apresentar suas maledicências sob o véu do engano, no caso, aparentando razões filosóficas. Mesmo ciente dos avisos do amigo, o protagonista introduz uma pequena digressão:

BERGANZA. Seguro puedes estar, Cipión, de que más murmure, porque así lo tengo prosupuesto. Es, pues, el caso, que me estaba todo el día ocioso y la ociosidad sea madre de los pensamientos ${ }^{79}$, di en repasar por la memoria algunos latines que me quedaron en ella de muchos que oí cuando fui con mis amos al estudio, con que, a mi parecer, me hallé algo más mejorado de entendimiento, y determiné, como si hablar supiera, aprovecharme dellos en las ocasiones que se me ofreciesen, pero en manera diferente de la que se suelen aprovechar algunos ignorantes. (CERVANTES, 2005, p. 675)

\footnotetext{
${ }^{79}$ CERVANTES, Miguel de. Novelas ejemplares. Barcelona: Crítica, 2005. Nota de Jorge García Lopez, p. 675. Cita a tópica ciceroniana do ócio proveitoso. "De Publio Escipión, Marco, hijo mío, el primero que fue llamado Africano escribió Catón, [...] que solía decir que nunca estaba menos ocioso que cuando estaba ocioso ni menos solo que cuando estaba solo." $(3,1)$ (extraído em: Cicerón, Marco Tulio. Sobre los deberes. Madrid: Alianza Editorial, 2008. p. 193.)
} 
Realmente, Berganza aproveita as horas em que se encontrava preso e ocioso para tecer um comentário com respeito ao uso indiscriminado do latim. Cabe observar que o estudo dessa digressão se deve ao fato de que nesse período do século XVII, alguns estamentos da sociedade, para alcançarem certo prestígio, imitavam a nobreza tanto por intermédio das aparências, como se observou no subcapítulo anterior, quanto por meio do estudo do latim, desencadeando certos comportamentos inadequados em membros da plebe. Essas atitudes provocaram a aplicação de medidas que viriam a restaurar a ordem hierárquica do corpo político, mediante pragmáticas reais, cujas diretrizes coibiam e penalizavam o acesso dessa plebe a determinados privilégios. Dessa forma, acrescenta-se o estudo dessa digressão com a intenção de complementar e ilustrar as análises anteriores, cujo tema das aparências surge no instante em que os personagens secundários tentam aparentar aquilo que não são, de acordo com a narrativa de Berganza.

De volta à digressão, é útil verificar as falas do protagonista que se seguem:

BERGANZA. Hay algunos romancistas ${ }^{80}$ que en las conversaciones disparan de cuando en cuando con algún latín breve y compendioso, dando a entender a los que no lo entienden que son grandes latinos, y apenas saben declinar un nombre ni conjugar un verbo. (CERVANTES, 2005, pp. 675-6)

Evidentemente, a censura de Berganza persegue uma tópica recorrente em algumas obras satíricas do século XVII, cujos textos tratam da utilização indistinta do latim, seja por aqueles que o desconhecem, seja com conhecimento, evidenciando certas atitudes inadequadas, conforme as seguintes observações de Cipión:

\footnotetext{
${ }^{80}$ Conforme nota contida na edição das Novelas ejemplares utilizada nessa dissertação, "romancistas são aqueles que não sabem latim, mas aparentam sabê-lo". Um tema encontrado em algumas produções satíricas do XVI e XVII, também mencionado por Cervantes no prólogo da primeira parte de Dom Quixote.
} 
CIPIÓN. Por menos daño tengo ése que el que hacen los que verdaderamente saben latín, de los cuales hay algunos tan imprudentes que hablando con un zapatero o con un sastre arrojan latines como agua. (CERVANTES, 2005, p. 676)

Apesar de alguns fazerem uso do latim sem qualquer discernimento, conforme as afirmações do protagonista, sua aplicação era reconhecida no período como sinônimo de prestígio e erudição, embora esse uso não fosse acessível à plebe. Isso se justifica pelo fato de o latim ser utilizado no trato de temas elevados, caracterizando-se como língua de cultura. Adotados pelos colégios religiosos, o latim e o grego ${ }^{81}$, juntamente com outros saberes, tais como: "a poesia e a história gregas e latinas, a filosofia aristotélica, estoica, neoplatônica e escolástica, a retórica aristotélica e ciceroniana", conforme Hansen, tinham como propósito instituir um modelo de vida que primasse por hábitos nobres, conduzindo os homens por caminhos virtuosos ${ }^{82}$.

Entretanto, é importante lembrar que no século XVI, em muitas cidades espanholas surgiram as chamadas "escolas de gramática", voltadas ao ensino do latim. Essas instituições foram favorecidas pelos Reis Católicos e pelos primeiros Áustrias ${ }^{83 .}$ Nesse sentido, José Manuel Domíngues García relata, em seu artigo sobre "La cátedra de latinidad de Betanzos (1614-1853)”, que, por ser uma língua usada tanto pelo clero quanto na elaboração de documentos jurídicos, seu estudo tinha como objetivo auxiliar não somente a administração do Estado moderno, como também na formação daqueles que abraçavam os ofícios eclesiásticos, ou seja, sua difusão vinha como resposta às necessidades da burocracia que surgia na nação (p. 62). Além disso, segundo o pesquisador, o que se pode perceber é que a grande difusão do ensino do latim estabelecia uma forma de ascensão social, não cogitada naquele período do Antigo

\footnotetext{
${ }^{81}$ HANSEN, João A. "Educando príncipes no espelho". In: FREITAS, Marcos Cezar de; KUHLMANN Jr. Moysés (Orgs.). Os intelectuais na história da infância. São Paulo: Cortez, 2002. p. 77.

${ }^{82}$ Idem, p. 77.

${ }^{83}$ DOMÍNGUEZ GARCIA, José Manuel. "La cátedra de latinidad de Betanzos (1614-1853)". Disponível em: http://anuariobrigantino.betanzos.net/Ab1995PDF/1995\%20061_076.pdf. Acesso em: 6 jan. 2014.
} 
Regime, mesmo porque até então o latim, como língua litúrgica, estava restrito apenas àqueles que tivessem interesse em seguir carreira jurídica ou eclesiástica (p. 61).

No entanto, no século XVII, por meio da pragmática de 10 de fevereiro de 1623, Felipe IV limita seu ensino, vinculando sua permanência a cidades que possuíssem um magistrado ou corregedor ${ }^{84}$.

Em outras palavras, segundo Felipe IV, "los pueblos deben abstenerse de fundar escuelas de gramática ya que los campesinos abandonan la agricultura por las letras" (p. 63). Dessa forma, esse conhecimento tornava-se restrito, pois sua aplicação exigia prudência e cautela, até mesmo porque segundo Hugues Didier ${ }^{85}$, em seu estudo sobre Censura e idiomas en la España del Siglo de Oro: Juan Eusebio Nieremberg como escritor neo-latino, existia uma evidente periculosidade quanto aos assuntos nobres ou elevados se acharem ao alcance da plebe.

Mesmo assim, o latim permaneceu nas instituições de ensino da época, especialmente nos tratados didáticos ou espelhos de príncipes, cuja matéria era tida como símbolo de natureza superior e educação primorosa (p. 77). Até porque, segundo Hansen, os eruditos deveriam falar e ler latim, línguas vulgares e o grego, entre outros saberes (p. 87). No entanto, ao citar o texto de Palmyreno, o pesquisador fornece informações sobre os mestres domésticos e mestres-escola, com respeito ao uso inapropriado do latim, "voltado contra os mestres pelos alunos" (p. 89). Esses mestres, pagos por aqueles que dispunham de certa condição econômica, perseguiam o objetivo de instruir seus filhos, emulando uma educação aristocrática, embora se vissem

\footnotetext{
${ }^{84}$ FELIPE IV, en Madrid por pragmática de 10 de febrero de 1623 en los capítulos de reformación cap. 22 Ley I. Disponível em: http://fama2.us.es/fde/ocr/2006/novisimaRecopilacionT1.pdf. Acesso em: 2 dez. 2013. "Porque de haber en tantas partes de estos Reynos estudios de Gramática se consideran algunos inconvenientes, pues ni en tantos lugares puede haber comodidad para enseñarla, ni los que la aprenden quedan con el fundamento necesario para otras Facultades; mandamos, que en nuestros Reynos no pueda haber ni haya estudios de Gramática, sino es en las ciudades y villas donde hay Corregidor, [...]."

${ }^{85}$ DIDIER, Hugues, Censura e idiomas en la España del Siglo de Oro: Juan Eusebio Nieremberg. Disponível em: http://cvc.cervantes.es/literatura/aiso/pdf/04/aiso_4_1_049.pdf. Acesso em: 17 dez. 2013.
} 
obrigados a fazer determinados serviços domésticos, tais como: "servir à mesa, retirar pratos, cuidar da mula" etc. (p. 89).

Embora existissem problemas envolvendo o uso indevido do latim, ora por mestres, ora por aqueles que o desconhecessem, o certo é que o latim se mantinha na vida intelectual, pois era a língua do ambiente culto e clerical; tratar da arte poética, histórica, científica ou teológico-filosófica significava usar o latim (p. 543), pois conforme Didier: "El atrevimiento de Fray Luis de León no hubiera sido atrevimiento en latín: los tratados exegéticos españoles-latinos de la segunda mitad del siglo XVI y XVII lo superan.” (p. 544)

Diante da debilidade da imprensa espanhola ou a pouca inclinação de se estabelecer conversas em latim nas aulas, não se pode inferir que não valesse a pena estudar obras escritas por espanhóis em um idioma que não era seu, até porque se tratava de uma língua da Igreja católica e sobretudo da ciência e dos setores da cultura europeia (p. 544).

No entanto, ao se analisar essa passagem da novela, as censuras tanto de Berganza quanto de Cipión não se referem ao uso do latim, mas sim às praticas daqueles que o aplicam de forma inadequada. Evidentemente, trata-se de uma murmuração que de certa forma aponta para os abusos sociais cometidos por aqueles que não possuem discernimento, discrição, não respeitam os critérios relacionados à conveniência de um discurso seja em latim, seja em língua vulgar.

Na sequência, Cipión pede para que Berganza comece a dizer suas filosofias. $\mathrm{O}$ mastim admite que já foram ditas. Indignado, Cipión o repreende:

CIPIÓN. ¿Al murmurar llamas filosofar? ¡Así va ello! Canoniza, canoniza, Berganza, a la maldita plaga de la murmuración, y dale el nombre que quisieres, que ella dará a nosotros el de cínicos, que 
quiere decir perros murmuradores; [...] (CERVANTES, 2005, pp. 676-7).

Diante da relação que Cipión estabelece entre a atitude murmurante de Berganza e os cínicos, é oportuno tecer algumas considerações a respeito do modo de pensar e agir desses filósofos, mais especificamente de Diógenes de Sínope. Nesse sentido, ao observar o trabalho de Diógenes Laércio, o autor descreve os preceitos referentes ao cinismo, visto como um pensar crítico, subversivo, que se expressa através da anedota, dos gestos. Esse procedimento cínico promove o riso sarcástico como forma de negação dos refinamentos da civilização, face ao empobrecimento das virtudes morais (DIÓGENES LAÉRCIO, 2011, p. 12). Dessa forma, através de sua erudição, com muita ironia e mordacidade, os filósofos cínicos introduziam uma censura ao sistema ideológico vigente, contra a sociedade e a opinião dominante. Diante das atitudes que sustentavam, a população os intitulava "cães", pois viviam sem pudor e sem decência pelas praças de Atenas ou no mercado de Corinto, como símbolo da ação bestial e da falta de vergonha. Certamente, no caso dos cínicos, essa atitude sem pudor, natural, assumida mediante uma postura agressiva, se justificava como tomada de posição crítica diante dessa sociedade e seus objetivos (GARCÍA GUAL, 2011, p. 22).

Sendo assim, ao rever a natureza canina dos protagonistas da novela, pode-se supor que Berganza e Cipión nada mais são que a representação dos cínicos, não somente pela própria natureza, mas pelas colocações filosóficas e irônicas direcionadas ora às práticas viciosas da sociedade que os rodeia, ora à falta de moral que a degenera.

Embora houvesse se deparado com alguns tipos corruptos em seu caminho, Berganza percebia que sua sorte ainda lhe reservava algumas surpresas. Dando continuidade a suas reminiscências, o protagonista relata a Cipión os acontecimentos que testemunhava na casa de seu amo, no momento em que a noite surgia. 
BERGANZA. Dígolo porque la negra de casa estaba enamorada de un negro asimismo esclavo de casa, $[\ldots]$ y no se podían juntar sino de noche, $[\ldots]$ y así, las más de las noches bajaba la negra, y, tapándome la boca con algún pedazo de carne o queso, abría al negro, con quien se daba buen tiempo, facilitándolo mi silencio, y a costa de muchas cosas que la negra hurtaba. (CERVANTES, 2005, pp. 677-8)

Nesse trecho da novela, Berganza descreve com que habilidade a escrava o aliciava. A princípio, Berganza aceitava os alimentos, facilitando o encontro dela com o outro escravo. No entanto, levando em conta sua boa natureza,

BERGANZA. [...] quise responder a lo que a mi amo debía, pues tiraba sus gajes y comía su pan, como lo deben hacer no sólo los perros honrados, a quien se les da renombre de agradecidos, sino todos aquellos que sirven. (CERVANTES, 2005, p. 678)

Novamente no "Coloquio" os cães retomam o tema da lealdade e das relações entre criados e amos, especialmente no que diz respeito à confiança. Desde o início da novela Berganza insiste nessa questão em particular; os problemas ocorridos no matadouro de Sevilha, a mentira e a deslealdade dos pastores para com o dono do rebanho, infringindo a confiança que lhes foi atribuída. No caso da escrava, não só roubava o rico comerciante para alimentar secretamente Berganza, com o intuito de aliciá-lo, como também insistia em uma situação amorosa, contrariando as ordens do amo e, consequentemente, as leis daquela casa.

Deve-se ainda declarar que nos séculos XVI e XVII, segundo Emilio García Gómez havia um elevado número de negros na Espanha provenientes da Etiópia e da Guiné, os quais eram aproveitados como servos, no desempenho de serviços mais baixos. ${ }^{86}$ Conforme o cronista Luiz de Peraza, ao mencionar o primeiro terço do século

\footnotetext{
${ }^{86}$ GARCÍA GÓMEZ, Emilio Los negros en España disponível em :http://www.etnografo.com/negros_espana.htm, acesso em 16/01/2014
} 
XVI: "Hay infinita multitud de negras y negros de todas las partes de Etiopía y Guinea, de los cuales nos servimos en Sevilla y son traídos por la vía de Portugal.” 87

De acordo com García Gómez, o trabalho escravo em Sevilha não era excessivamente duro. Aliás, possuir escravos era sinônimo de prestígio e distinção, sem contar que a mão de obra era barata. Por essa razão, a maioria dedicava-se aos serviços domésticos, especialmente as mulheres ${ }^{88}$.

No entanto, o que convém verificar nessa passagem da novela é que desde seu início são observados pelos protagonistas os aspectos relacionados a práticas decorosas. Para Antony Close, além de ser um tema persistente nessa novela exemplar, o decoro torna-se primordial na obra de Cervantes ${ }^{89}$. Nesse caso, o decoro faz referência à conveniência, aos aspectos a serem considerados levando-se em conta a representação desses personagens como membros integrantes de uma hierarquia social. Em outras palavras, os escravos contrariavam as determinações do amo, não se apresentavam condizentes à posição que ocupavam nessa hierarquia. O que se constata é que Cervantes, através de seus personagens caninos, em diversas ocasiões no "Coloquio" censura a falta de decoro, seja dos açougueiros e frequentadores do Matadouro de Sevilha, seja dos pastores com relação ao próprio ofício. Agora se está diante das ações indecorosas dos escravos de propriedade do rico comerciante.

Paralelamente, para Antonio Álvarez Ossorio Alvariño, em seu artigo "Rango y aparencia: el decoro y la quiebra de la distinción en Castilla", o decoro também estabelece uma relação direta entre o ser e o aparentar, fazendo referência ao lema

\footnotetext{
${ }^{87}$ POZO RUIZ, Alfonso. Los esclavos en la Sevilla del siglo XVI.

Disponível em: http://personal.us.es/alporu/histsevilla/esclavos_sevilla.htm. Acesso em: 16 jan. 2014.

88 Ídem. s/n.

${ }^{89}$ CLOSE, Antony. Cervantes y la mentalidad cómica de su tiempo. Alcalá de Henares: Centro de Estudios Cervantinos, 2007. p. 64.
} 
noblesse oblige $e^{90}$. Assim, para o pesquisador a noção de decoro está intimamente vinculada ao conceito de honra, pois

ambos recogen el conjunto de obligaciones que conlleva la pertenencia a un estamento hegemónico; ya sea en relación a los otros miembros de un mismo estado como frente a los componentes de otros estamentos. (p. 265)

Nessa configuração, segundo o Diccionario de Autoridades, citado pelo pesquisador, decoro significa "honor, respeto, reverencia que se debe a alguna persona por su nacimiento o dignidad" (p. 265). Por conseguinte, enquanto os inferiores manifestam reverência aos superiores, estes devem demonstrar amor y dilectio (preferência na estima), a fim de conservar a hierarquia e concórdia comuns (p. 265).

Diante disso, Berganza decide passar de "sobornado primero, y de concienzudo alguacil moral después" (p. 67), segundo Close, procurando de alguma forma coibir os abusos dos dois escravos, para que pudessem retornar às suas obrigações, isto é, obrigações inerentes daqueles que servem.

BERGANZA. Digo, pues, que habiendo visto la insolencia, ladronicio y deshonestidad de los negros, determiné, como buen criado, estorbarlo por los mejores medios que pudiese; y pude tan bien que salí con mi intento. Bajaba la negra, como has oído, a refocilarse con el negro, fiada en que me enmudecían los pedazos de carne, pan o queso que me arrojaba. ¡Mucho pueden las dádivas, Cipión! (CERVANTES, 2005, p. 680)

No entanto, antes de pôr em prática o propósito de coibir os atos indecorosos dos escravos, Berganza recorda um refrão latino que aprendera na Companhia de Jesus: Habit bovem in lingua. ${ }^{91}$

\footnotetext{
${ }^{90}$ Ossorio Alvariño, Antonio Álvarez. "Rango y aparencia: el decoro y la quiebra de la distinción en Castilla”. Disponível em: http://rua.ua.es/dspace/bitstream/10045/4776/1/RHM_17_14.pdf. Acesso em: 6 jan. 2014. p. 265.

${ }_{91}$ Conforme nota da edição, o provérbio de origem clássica significa: calar em troca de dinheiro.
} 


\section{Para Cipión:}

CIPIÓN. ¡Oh, que en hora mala hayáis encajado vuestro latín! ¿Tan presto se te ha olvidado lo que poco ha dijimos contra los que entremeten latines en las conversaciones de romance? (CERVANTES, 2005, p. 680)

Mas para Berganza a frase procedia, uma vez que se achava mudo. Nem ousava latir quando a negra descia para encontrar-se com o outro escravo. Com isso, o protagonista reforça sua afirmação: "[...] Por lo que vuelvo a decir que pueden mucho las dádivas. (CERVANTES, 2005, p. 681).

É interessante observar que nesse subcapítulo os cães intercalam uma série de digressões. A primeira, com respeito ao uso indiscriminado do latim, a fim de ridicularizar tanto pedantes quanto aqueles que fingem conhecer a língua. A segunda digressão diz respeito à advertência de Cipión ao que se refere à murmuração. No entanto, logo em seguida, Cipión censura os ambiciosos e Berganza faz uma breve explanação sobre a hipocrisia. Mais adiante, Berganza pede ao amigo que fale sobre o significado de "filosofia", que para o protagonista significa "amador de la ciencia". Após ser questionado sobre seu conhecimento de nomes gregos, Cipión diz a Berganza que esse conhecimento é passado para as crianças na escola, muito embora há muitos que usam a língua grega sem conhecê-la. Nova digressão, agora Berganza fala sobre os enganos, comparando-os com as atitudes dos portugueses para com os negros da Guiné. Repreendido mais uma vez por Cipión, Berganza fala sobre o suicídio de Corondas de Tirio, pois o mesmo estabeleceu que os homens não deveriam portar armas nas assembleias da cidade. Descuidou-se e entrou em uma reunião com a espada cingida, fazendo com que a lei lhe fosse aplicada.

O que se pode pensar diante dessa série de digressões é que foram inseridas no texto com o propósito de promover o riso, o entretenimento. Sem contar que esse 
episódio da novela faz uso também de uma fábula de Esopo, um refrão, transformando a censura amarga, como já observado em outros capítulos, em uma narrativa que tende ao burlesco. Para Antony Close ${ }^{92}$,

al centrarse nuestra atención en esta disputa cómica, se dispersa nuestra conciencia de que Berganza nos ha suministrado subrepticiamente la medicina de un exemplum clásico, un refrán, numerosas reflexiones satíricas y la fábula esópica [...] transformada en la historia realista de sus intentos de poner fin a los idilios nocturnos de los dos amantes negros. (p. 68)

Para efeito de análise, escolhi a digressão que mais se aproximou da linha de estudos proposta desde o início do subcapítulo, ou seja, o uso indevido do latim, cujo tema se estende para questões tais como: as aparências, o decoro social e sua relação com a honra, aspectos selecionados para as devidas análises desse episódio do "Coloquio". No entanto, as digressões foram relacionadas para exemplificar como a comicidade pode ser introduzida, no instante em que Cervantes, novamente, utiliza-se de princípios morais e religiosos para introduzir uma paródia da vida cortesã. Algo que conforme os estudos de Close recorda as conversações de Dom Quixote e Sancho, suas frequentes réplicas, bem como os intermináveis refrães (p. 68).

Assim, retornando ao idílio amoroso dos dois escravos e o silêncio subornado de Berganza, uma noite o arrependido mastim decide acabar com "las malas dádivas de la negra"; evitando os latidos a fim de não acordar os demais membros da casa.

BERGANZA. [...] en un instante le hice pedazos toda la camisa y le arranqué un pedazo de muslo, burla que fue bastante a tenerla de veras más de ocho días en la cama fingiendo para con sus amos no sé qué enfermedad. Sanó, volvió otra noche, y yo volví a la pelea con mi

\footnotetext{
${ }^{92}$ CLOSE, Antony. Cervantes y la mentalidad cómica de su tiempo. Alcalá de Henares: Centro de Estudios Cervantinos, 2007.
} 
perra, y, sin morderla, la arañe todo el cuerpo, como si fuera hubiera cardado como manta. (CERVANTES, 2005, p. 681)

Percebe-se nesse parágrafo o tratamento dispensado por Berganza para com a negra escrava intitulada pejorativamente como "mi perra". O termo introduz dois sentidos concomitantemente válidos, pois se em um primeiro instante o mastim equipara a escrava com uma cadela, devido ao comportamento sexual e à falta de pudor apresentados com relação ao outro escravo da casa, ao mesmo tempo o termo "perra" estabelece uma analogia entre a ação bestial da escrava e seus atos ilícitos, tais como: roubo, falta de lealdade, desrespeito etc. O pesquisador Giovanni Previtali-Morrow ${ }^{93}$, em seu artigo intitulado "Unos aspectos autobiográficos de Cervantes en 'El coloquio de los perros", ao analisar a mesma passagem da novela, afirma que Cervantes conseguiu ridicularizar os homens não somente fazendo os cães parecerem mais inteligentes, como também "representando a los humanos más perros que los perros" (p. 430).

Nesse sentido, as batalhas de Berganza com a escrava "eran a la sorda"; sempre o cão saindo vencedor e a negra "malparada y peor contenta". Entretanto, a irritação da escrava ficava retratada na aparência do pobre mastim.

BERGANZA. Alzóseme con la ración y los huesos, y los míos poco a poco iban señalando los nudos del espinazo. Con todo esto, aunque me quitaron el comer, no me pudieron quitar el ladrar. Pero la negra, por acabarme de una vez me trujo una esponja frita con manteca, conocí la maldad; vi que era peor que comer zarazas, porque a quien la come se le hincha el estómago y no sale del sin llevarse tras sí la vida. (CERVANTES, 2005, pp. 681-2)

\footnotetext{
${ }^{93}$ Previtali-Morrow, Giovanni. "Unos aspectos autobiográficos de Cervantes en 'El coloquio de los perros"”. Disponível em: http://cvc.cervantes.es/literatura/aih/pdf/04/aih_04_2_041.pdf. Acesso em: 14 ago. 2013.
} 
O que se pode notar é que a Berganza não restava outra alternativa a não ser fugir daquela casa para não acabar morto. Assim, se está diante de mais um amo, mais uma censura às ações desonestas desses tipos sociais, em que os personagens caninos se divertem ao narrar e opinar sobre as fraquezas humanas (CLOSE, 2007,p. 69). As relações entre amo e criados nessa passagem apontam para problemas encontrados nessa sociedade, tais como: a falta de lealdade, bem como aqueles que se aproveitam da posição que ocupam para se impor aos inferiores, tidos como humildes no "Coloquio". Apesar de a criada ser uma escrava e sustentar uma posição "hierarquicamente" mais elevada em comparação ao pobre Berganza, as práticas malignas da negra não deixam dúvidas: trata-se de um abuso de poder. Diante desse pretenso poder da escrava, o personagem decide fugir. 
IV. “EL FAMOSO PERRO DE AYUDA” E O OFICIAL DE JUSTIÇA 


\section{Berganza, um possível ator de entremez}

Una mentira no tendría sentido si la verdad no fuera percibida como peligrosa.

Alfred Adler

Inicia-se este episódio do "Coloquio" no momento em que Berganza, ao acharse solto e sem "decir adiós a ninguno de casa", (p. 682) foge, deixando para trás a convivência que tivera com o rico comerciante. Entretanto, após andar alguns metros, o mastim se depara com um oficial de justiça, amigo de seu primeiro amo Nicolás el Romo, o qual imediatamente lhe reconhece, chamando-o pelo nome.

BERGANZA. [...] me llegué a él con mis acostumbradas ceremonias y caricias. Asíome del cuello y dijo a dos corchetes suyos: "Éste es famoso perro de ayuda que fue de un grande amigo mío; llevémosle a casa". (CERVANTES, 2005, p. 682)

Novamente no "Coloquio" observa-se as atitudes sustentadas por Berganza quando se depara pela primeira vez com um possível amo - como sempre, apresentando suas "acostumbradas ceremonias y caricias". Dessa forma, o cão introduz, nesse primeiro contato, uma espécie de cumprimento, de reverência, ou seja, procura seguir as regras utilizadas no trato entre pessoas de bem ou supostamente de bem, como se verá mais adiante.

Frente às afirmações do oficial de justiça, os beleguins alegram-se e decidem levá-lo, pois “si era de ayuda a todos sería de provecho” (p. 682).

Entretanto, antes de iniciar a narrativa sobre esse novo amo, Berganza introduz uma pequena digressão referindo-se à sua vida, atribuindo tanto os acontecimentos 
felizes quanto as desventuras passadas, nesse ponto de suas reminiscências, à variável roda da fortuna: "BERGANZA. Considera, Cipión, ahora esta rueda variable de la fortuna mía; ayer me vi estudiante, hoy me ves corchete.” (CERVANTES, 2005, p. 683).

Por ser um tema que não somente possui certa relevância, como também estabelece referências com o episódio anterior, decidiu-se fazer uma breve análise com respeito a essa pequena digressão do protagonista. É interessante verificar como essa tópica relacionada à fortuna, ao fado ou destino fez parte de algumas composições desse período.

Representada na iconografia por uma grande roda a qual é movida pela deusa grega Tyche, ${ }^{94}$ a Fortuna no mundo antigo era um símbolo positivo de fertilidade e fartura. Na Idade Média, legitimada através da escrita de Boécio, em sua célebre obra De consolatione philosophiae, (523 d.C.), a Fortuna é uma deusa que conduz a roda, cujo movimento giratório é responsável pelo destino da humanidade. Na baixa Idade Média, a Fortuna sozinha não tem qualquer valor para o homem, a não ser que esteja acompanhada pela virtude. No princípio da Idade Moderna, o tema da Fortuna se constitui por preceitos religiosos, embora seja vista como instável, frágil ${ }^{95}$ como um cristal e rápida, incitando os homens a aproveitarem a ocasião (p. 175).

Nesse aspecto, ao retornar à escritura da novela, Berganza se queixa com respeito à roda variável da fortuna, recorda os momentos felizes quando se encontrava na posição de estudante na escola da Companhia de Jesus; agora, após tantas adversidades, se vê transformado em "perro de ayuda", em "corchete". Para o

\footnotetext{
${ }^{94}$ Para Sánchez Márquez, conforme a Teogonia de Hesíodo, Tyche era filha de Tethys e Oceano. Venerada na Grécia como divindade protetora das cidades. A essa função acrescentou-se a ideia de que a deusa era responsável pela boa ou pela má sorte, convertendo a divindade em um ser instável, com a capacidade de decidir o destino de qualquer mortal.

Disponível em: http://www.ehumanista.ucsb.edu/volumes/volume_17/pdfs/articles. Acesso em: 4 fev. 2014.

95 ARELLANO, Ignacio. "Visiones y símbolos emblemáticos en la poesía de Cervantes". Disponível em: analescervantinos.revistas.csic.es/index.php/.../164. Acesso em: 10 fev. 2014.
} 
personagem, como mencionado no capítulo anterior, ao passar de um estado feliz para um desgraçado, melhor seria morrer que seguir vivendo. No entanto, diante das queixas de Berganza e da possível retomada de um tema já discutido por ambos, Cipión responde:

CIPIÓN. Así va el mundo, y no hay para qué te pongas ahora a esagerar los vaivenes de fortuna, como si hubiera mucha diferencia de ser mozo de un jifero a serlo de un corchete. No puedo sufrir ni llevar en paciencia oír las quejas que dan de la fortuna algunos hombres que la mayor que tuvieron fue tener premisas y esperanzas de llegar a ser escuderos. (CERVANTES, 2005, p. 683)

O que se constata nesse fragmento é que para Cipión tanto um açougueiro quanto um oficial de justiça ou beleguim não representam nenhum tipo de "fortuna", no caso referindo-se a um estado de ventura, sucesso, até porque ambos pertencem à mesma ordem social, à plebe. Por essa razão, para o protagonista a roda da fortuna apresenta um movimento sem variações, pois não há distinções entre os dois amos, o que não deixa de ser uma censura irônica e aguda. É oportuno recordar que, segundo Baltasar Gracián, a censura também possui suas variações e artifícios,

[...] Y aunque cualquiera sentencia es concepto, porque esencialmente es acto del discurso una verdad sublime, recóndita y prudente, pero las que son propias de esta arte de agudeza, son aquellas que se sacan de la ocasión y les da pie alguna circunstancia especial, de modo que no son sentencias generales, sino muy especiales, glosando alguna rara contingencia por ellas ${ }^{96}$

De fato, Cipión se aproveita das queixas de Berganza para tecer um comentário malicioso, embora agudo, partindo da afirmação de que as diferenças estamentais entre os amos não existem, mesmo quando o mastim frequentava o colégio com os filhos do

\footnotetext{
${ }^{96}$ GRACIÁN, Baltasar. Agudeza y arte de ingenio. Madrid: Editorial Castalia, 1987. p. 20.
} 
rico comerciante. Apesar de serem tratados com toda a pompa como se fossem filhos de algum príncipe, evidentemente, tudo não passava de mera aparência, pois sustentavam aquilo que não eram, perseguindo o modelo de um estamento social, no caso a nobreza, ao qual jamais pertenceriam. Dessa forma, o cão censura os pequenos anseios do homem, estabelecendo um paralelo entre essas aspirações e sua posição na sociedade, pois quanto mais baixo e vulgar é o ser, menores são suas pretensões, que chegariam apenas à condição de escudeiro.

Assim, diante desse mundo de pequenas ambições, Berganza inicia esse episódio descrevendo seu novo amo, um oficial de justiça corrupto, e a relação que estabelecia com os rufiões de Sevilha.

BERGANZA. [...] Y has de saber que este alguacil tenía amistad con un escribano, con quien se acompañaba. Estaban los dos amancebados con dos mujercillas no de poco más a menos, sino de menos en todo. (CERVANTES, 2005, p. 683)

Perseguindo a afirmação do protagonista, ao observar "las dos mujercillas", podia-se notar que lhes faltavam virtudes e suas práticas sociais eram reprováveis. Verifica-se o uso de advérbios de intensidade: "más y menos" como recurso de linguagem a fim de expressar um julgamento, uma censura sobre as duas mulheres. Desse modo, o jogo de palavras usado pelo protagonista deixa implícito afetos que transitam entre o escárnio e o desdém, carregados de muita ironia.

Seguindo em sua descrição, Berganza observa que: “[...] verdad es que tenían algo de buenas caras, pero mucho de desenfado y de taimería putesca." (CERVANTES, 2005, p. 683).

Mediante tal observação, a ironia persiste por intermédio do tom pejorativo utilizado pelo protagonista, no momento em que descreve a aparência das damas. Ao 
fazer uso da expressão: "taimeria putesca", o cão relata que possuíam a astúcia própria daquelas que sustentam esse tipo de mal viver, isto é, a prostituição.

Nesses termos, por entender que esse episódio se assemelha a um entremez, levando-se em conta as características que apresenta, a intenção dessa análise será estabelecer analogias entre essa passagem da novela com essa breve encenação burlesca, introduzida nos intervalos das peças teatrais nos séculos XVI e XVII.

Por esse motivo, a princípio, cabe um maior aprofundamento a respeito desse gênero tido como menor nesse período, cuja autoria nem sempre era assumida pelos seus compositores ${ }^{97}$, apesar de que Cervantes não só os reconhecia, como os intitulava "hijos legítimos de su ingenio". O autor publica todos os seus Ocho entremeses nuevos, nunca representados no ano de 1615, em Madri, a fim de que "se vea de espacio lo que pasa de prisa" ${ }^{98}$.

No entanto, o que quis dizer Cervantes com essa afirmação: "para que se vea de espacio lo que pasa de prisa"? Deve-se recordar que essa breve composição teve sua entrada no cânone teatral por intermédio de Lope de Rueda, ${ }^{99}$ autor admirado por Cervantes desde sua mocidade (p. 173). É oportuno destacar que Eugenio Asensio, em seu livro Itinerário del entremés, ${ }^{100}$ dedicou um primoroso trabalho sobre o gênero, sendo que alguns parâmetros da análise aparecem com frequência em seus estudos críticos, dentre eles destacaria as relações do entremez com a sociedade, sua fala e

\footnotetext{
97 ASENSIO, Eugenio. "Entremeses". In AVALLE-ARCE, Juan Bautista; RILEY, E. C. Suma cervantina. London: Tamesis, 1973. p. 171.

${ }^{98}$ Idem, 1973. pp. 170-1.

${ }^{99}$ O primeiro exemplo de companhia ambulante ou teatro itinerante tem sua origem através da atividade do dramaturgo e poeta cômico, o grego Tepis de Icaria, século VI a.C. O segundo exemplo foi protagonizado pela companhia de Lope de Rueda Navarro (natural de Toledo), entre 1540 e 1565 na Espanha dos primeiros Áustrias. Cervantes o referenda de maneira elogiosa em sua obra Ocho comedias y ocho entremeses, nunca representados (1615).

Disponível em: http://es.wikipedia.org/wiki/Teatro_itinerante. Acesso em: 20 fev. 2014.

100 ASENSIO, Eugenio. Itinerário del entremés desde Lope de Rueda a Quiñone de Benavente. Madrid: Gredos, 1971.
} 
costumes, ao descreverem tipos e ambientes, oferecendo um repertório de temas, personagens e gracejos.

El entremés constituye un tipo teatral fijado por Lope de Rueda que se mueve entre dos polos: el uno la pintura de la sociedad contemporánea con su habla y costumbres; la literatura narrativa, descriptiva o dramática. De la literatura oral o escrita, es decir, de la facecia, la acción celestinesca, la novela picaresca, la fantasía satírica, la descripción de tipos y ambientes, toma sobre todo un repertorio de asuntos, personajes, gracejos, atmosfera. De la comedia se apropia además de un almacén de asuntos, inspiraciones y modelos de forma y estilo." (ASENSIO, 1971, p. 25)

Nessa configuração, conforme os estudos de Eugenio Asensio ${ }^{101}$ em seu artigo "Entremeses", em la Suma Cervantina, essas peças eram protagonizadas por personagens de baixa condição, apresentando cenas de caráter cômico, sem instituírem qualquer relação com a comédia principal, pois ao introduzirem cenas jocosas sem interrupções acabavam se separando do contexto. Assim, com um discurso breve e divertido o entremez instituía por meio de suas representações, a variedade que tanto divertia e alegrava o público. Além disso, por não estabelecer quaisquer pretensões morais, essa pequena peça teatral não tinha outro alvo senão o deleite (p. 173).

Segundo os estudos do pesquisador essas pequenas representações teatrais abordavam temas relacionados: ao matrimônio, linhagem, dinheiro, à questão da honra, valores, loucura, generosidade, engano e desengano, introduzidos por meio de cenas cômicas ou de cunho satírico, embora Cervantes não instituísse em seus entremezes a corrosão típica, ao estilo de Quevedo, como se verá mais à frente. Com uma linguagem própria "de las figuras que en ellos se introducen", ${ }^{102}$ apresentava um exemplo proveitoso relacionado à conduta do homem como indivíduo dentro da sociedade.

101 ASENSIO, Eugenio. "Entremeses". In: AVALlE-ARCE, Juan Bautista; RILEY, E. C. Suma cervantina. London: Tamesis, 1973.

${ }^{102}$ CERVANTES, Miguel de. Entremeses. Madrid: Cátedra, 1989. p. 15. 
Ademais, os entremezes cervantinos tinham como palco as cidades espanholas como Madri e, no caso dessa passagem do "Coloquio", Sevilha, por onde transitavam personagens baixos, pertencentes à plebe, cujo objetivo estava em promover o riso, a alegria desatada, sem freio, não atendendo aos meios para consegui-la - seja mediante recursos finos, seja através de golpes baixos de comicidade (ASENSIO, 1973, p. 173).

Conforme Asensio, nesse pequeno gênero teatral a sociedade ri de suas convenções e de seus valores mais queridos, no momento em que os percebe representados por um desfile de figuras que se satisfazem por introduzirem um mundo de maneira invertida (p. 174).

Paralelamente, para Jesús G. Maestro ${ }^{103}$, em seu artigo “Cervantes y el entremes, poética de una comicidad crítica”, a comicidade exibida nos entremezes cervantinos se constitui através de três aspectos: o primeiro nem tanto pela ação, mas por meio da linguagem utilizada. Por isso, as personagens faziam uso de um discurso condicionado ao estamento ao qual pertenciam. O segundo aspecto diz respeito ao dinamismo ou brevidade, pois as situações ridículas e grotescas eram introduzidas com certa instantaneidade. Por fim, tem-se a pantomima ou lugar onde os signos verbais são levados ao extremo juntamente com a expressão gestual, vestuário, como forma de codificação das personagens. Nesse sentido, segundo o pesquisador, a censura expressa nos discursos tornava-se mais tolerável por intermédio das burlas, ao contrário de fazer uso das verdades, pois a brincadeira promove consequências cômicas muito mais insignificantes, mesmo porque "cuando la comedia es posible, la realidad es inevitable" (p. 530).

Nesse aspecto, para González Maestro, nos entremezes cervantinos pode-se observar que o autor ridiculariza um poder social e institucional, não querendo nem

\footnotetext{
${ }^{103}$ Gonzalez Maestro, Jesús. "Cervantes y el entremés, poética de una comicidad crítica”. Disponível em: http://cvc.cervantes.es/literatura/cervantistas/coloquios/cl_XII/cl_XII_37.pdf. Acesso em: 28 jan. 2014.
} 
seduzir nem vencer, mas simplesmente promover o riso, seja da perspectiva moral da Espanha dos séculos XVI e XVII, seja por intermédio da intolerância institucionalmente legitimada em um mundo que lhe coube viver (p. 526).

Logo, diante dos estudos expostos, o que se pode entender dessa frase "para que se vea de espacio lo que pasa de prisa" é que Cervantes, segundo Spadaccini nos comentários preliminares dos Entremeses cervantinos, por não conseguir ver seus entremezes representados, dirige-se ao leitor e o convida a fazer uma leitura tranquila e reflexiva sobre essas peças, porém como discursos escritos, cuja leitura implica, mais que um passatempo, observar a representação das condutas do homem como indivíduo e como ser social marginalizado, levando em conta suas limitações econômicas, estamentais, intelectuais (pp. 21-2).

Nesses termos, retornando à narrativa do "Coloquio", através da descrição metafórica das personagens secundárias, Berganza estabelece de que maneira essas práticas viciosas se fazem presentes e como se articulam nas relações existentes entre seu amo, o escrivão e as mulheres, conforme o parágrafo abaixo:

BERGANZA. Éstas les servían de red y de anzuelo para pescar en seco en esta forma: vestíanse de suerte que por la pinta descubrían la figura, y a tiro de arcabuz mostraban ser damas de la vida libre; andaban siempre a caza de estranjeros, y cuando llegaba la vendeja a Cáliz y a Sevilla, llegaba la huella de su ganancia, no quedando bretón con quien no embistiesen, y, cayendo el grasiento con alguna de esas limpias, avisaban al alguacil y al escribano adónde y a qué posada iban, y en estando juntos les daban asalto y los prendían por amancebados; pero nunca los llevaban a la cárcel, a causa que los estranjeros siempre redimían la vejación con dinero. (CERVANTES, 2005, pp. 683-4)

De acordo com o parágrafo acima, começam a ser descritos tantos os personagens desse possível entremez quanto o palco onde se desenvolverá a trama. A 
princípio têm-se: o oficial de justiça, o escrivão e os beleguins, as duas prostitutas, o marinheiro estrangeiro, tendo como ambiente o quarto de pensão. A representação desse entremez se dá por intermédio da narrativa de Berganza.

O que se pode notar pela descrição do protagonista é a linguagem utilizada pelos "personagens" nessa pequena cena da peça. Inicialmente, Berganza não somente faz uso de uma metáfora: "pescar en seco", para descrever o momento da abordagem e sedução das duas prostitutas, como também introduz termos em germanía ${ }^{104}$, tais como: "por la pinta descubrían la figura", sendo a palavra "figura" procedente do jogo de naipes; "vida libre", significando que de longe se podia notar que eram prostitutas. ${ }^{105}$ Partindo para a descrição das personagens, acrescida da linguagem utilizada, delineia-se o estereótipo de um grupo de pessoas com vícios que começam a ser evidenciados e censurados. Vícios que se transformam em deformidades constituídas por imagens verossímeis, cujo propósito está em realçar as vilezas, em especial, do oficial de justiça, seja por meio de seu caráter corrupto, seja pela maneira como suas práticas aliciam todos ao seu redor.

A paródia das figuras em cena, temas e motivos terá como alvo a corrupção presente nos meios públicos. Nesse aspecto, pode-se verificar que o tratamento cômico reservado tanto ao assunto quanto às personagens estará restrito ao estamento a que pertencem, ou seja, à plebe, ou, como observa Lope de Vega ${ }^{106}$ em sua Arte nuevo de hacer comedias, "porque entremés de rey jamás se há visto". Para Kenneth R.

\footnotetext{
104 Germanía: Jerga o manera de hablar de ladrones y rufianes, usada por ellos solos y compuesta de voces del idioma español con significación distinta de la verdadera, y de otros muchos vocablos de orígenes muy diversos. Disponível em: http://lema.rae.es/drae. Acesso em: 11 fev. 2014.

${ }_{105}$ CERVANTES, Miguel de. Novelas ejemplares. Barcelona: Crítica, 2005 (Notas da edição).

106 CERVANTES, Miguel de. Entremeses. Madrid: Catedra Letras Hispánicas, 1989. p. 15.
} 
Scholberg, ${ }^{107}$ em seus estudos atuais sobre Algunos aspectos de la sátira en el Siglo $X V I$ :

El satirizar a miembros de diferentes profesiones y clases sociales gozó de considerable popularidad en la Edad Media y siguió en el siglo XVI, aunque con ciertos cambios de énfasis. [...] Los escribanos y mercaderes son blancos de cortos ataques [...]. (SCHOLBERG, 1979, p. 30)

Conforme o pesquisador, ao citar as queixas do personagem Micilo en $E l$ crotalón, contra os escrivães, acrescenta que recebiam dos príncipes tal ofício, mesmo sendo "hombres viles y de ruynes castas y suelo; los cuales por pequeño interés pervierten el derecho y justicia del que la ha de haber." (SCHOLBERG, 1979, p. 30).

Um exemplo de como um pequeno interesse perverte o direito e a justiça pode ser observado na cena que culminou no golpe aplicado pelo oficial de justiça com a ajuda da Colindres, pois assim se chamava a "amiga" do amo de Berganza, contra mais um marinheiro estrangeiro "unto y bisunto", 108 , ou seja, endinheirado.

BERGANZA. Sucedió, pues que la Colindres [...] consertó con él la cena y noche en su posada; dio el canuto a su amigo; y, apenas se habían desnudado, cuando el alguacil, el escribano, dos corchetes y yo dimos con ellos. Alborotáronse los amantes, esageró el alguacil el delito, mandolos vestir a toda prisa para llevarlos a la cárcer, afligiose el bretón, terció, movido de caridad, el escribano, y a puros ruegos redujo la pena a solos cien reales. (CERVANTES, 2005, p. 684)

O mais curioso dessa ação, ocorrida na pensão onde a Colindres vivia, está no instante em que o marinheiro descobre que suas calças haviam sumido, juntamente com os "cinquenta escuti d'oro in oro" que nelas estavam. Na realidade, as calças não

${ }^{107}$ SCHOLBERG, Kenneth R. Algunos aspectos de la sátira en el siglo XVI. Switzerland: Peter Lang, 1979.

108 O sentido de "unto y bisunto" seria untado e novamente untado"; no texto é utilizado em duplo sentido: endinheirado, riquíssimo. Extraído da nota de rodapé das Novelas ejemplares, edição de Antonio Rey Hazaz e Florencio Sevilla Arroyo, Madrid, Espasa-Calpe, 2011. p. 272. 
haviam sido roubadas, mas retiradas do aposento por Berganza, interessado em "un pedazo de jamón" que no interior do traje se achava.

BERGANZA. Digo que halle en ella un pedazo de jamón famoso, y, por gozarle y poderle sacar sin rumor, saqué los follados a la calle, y allí me entregué en el jamón a toda mi voluntad, y cuando volví al aposento hallé que el daba voces diciendo en lenguaje adultero y bastardo, aunque se entendía, que le volviesen sus calzas, que en ellas tenia cincuenta escuti d'oro in oro. (CERVANTES, 2005, pp. 684-5)

Sem dúvida, as descrições de Berganza conduzem à atmosfera de comicidade do episódio, sem contar com as características burlescas apresentadas pelas personagens secundárias, no momento em que a ausência de caráter que as individualiza se torna evidente. Consequentemente, as relações sociais, diante da chantagem e da devassidão, entram em colapso, instituindo um jogo de interesses que tende a amplificar a própria deformação moral. Esse jogo de interesses torna-se mais evidente quando o oficial de justiça, diante do fracasso desse golpe, tenta extorquir dinheiro da hospedeira.

BERGANZA. [...] Llamola, y vino medio desnuda, y como oyó las voces y quejas del bretón, y a la Colindres desnuda y llorando, al alguacil en cólera y al escribano enojado y a los corchetes despabilando lo que hallaban en el aposento, no le plugo mucho. (CERVANTES, 2005, p. 685)

Certamente, a hospedeira já conhecia o oficial de justiça, a "ninfa Colindres" e as artimanhas de todo aquele grupo, pois sabia dos embustes que aplicavam nos marinheiros vindos de outras partes. Assim, sem rodeios procura assumir o controle da situação:

BERGANZA. "Señor alguacil y señor escribano, no conmigo tretas, que entrevo toda costura, no conmigo dijes ni poleos, callen la boca váyanse con Dios, si no, por mi santiguada que arroje el bodegón por la ventana y que saque a plaza toda la chirinola desta historia, $[\ldots]$ 
porque soy mujer honrada y tengo un marido con su carta de ejecutoria ${ }^{109}$ y con a perpenan rei de memoria, con sus colgaderos de plomo [...]”. (CERVANTES, 2005, pp. 685-6)

É interessante notar que a menção do título de fidalguia, feita pela hospedeira, foi tópica frequentemente abordada por alguns escritores satíricos do século XVI. Em suas obras, esses autores censuravam o uso indevido de títulos, feito por pessoas de estamentos inferiores. Nesse sentido, Scholberg cita como exemplo a anônima Segunda parte de Lazarillo de Tormes, extraindo da obra o fragmento que mais retrata o tema:

Lazarillo, convertido en atún, había captado el favor del rey de los peces, y le ofreció consejos para acrecentar su caudal. Uno de éstos era que cualquier de sus súbditos que pusiese "don" sin que le viniese el título por su linaje, pagase una contribución al rey. Dice que salió muy bien tal reglamento porque había tanta desvergüenza entre los atunes que todos, altos y bajos, buenos y malos, se atrevían a hacerse llamar "don". (SCHOLBERG, 1979, p. 66)

Cabe salientar que essas questões, no século XVI, tornaram-se tão frequentes que Felipe II, através da Pragmática de 1586, cujo tema refere-se à "orden que debe observarse en los tratamientos y cortesias de palabra y por escrito", determina:

Y mandamos, que à ninguna persona, de cualquier estado ó condición que sea, no siendo de las expresadas en esta nuestra ley, se les pueda llamar ni llame Señoría por escrito ni por palabra, ni a título de Consejo, dignidad eclesiástica ni seglar, ni oficio, ni otro pretexto ni color alguno; ni Ilustrísima sino es a los que se manda o permite llamar en esta nuestra ley; ni Excelencia a ninguno que no sea Grande. (D.FELIPE II, 1586, Livro VI, 19, p. 176) $)^{110}$

\footnotetext{
${ }^{109}$ Carta de ejecutoria: "entiéndase de hidalguia". Esse documento iniciava-se com "ad perpetuam rei memoriam". Os que a possuíam eram "hidalgos de ejecutoria", ou seja, provaram a nobreza mediante pleito, pois havia fidalgos que tinham comprado seus títulos, "hidalgos de privilegio". In: CERVANTES, Miguel de. Novelas Ejemplares - El Coloquio de los perros. Barcelona: Espasa, 2011.

110 Novísima Recopilación de las Leyes de España. Tomo III. Libros VI y VII. Disponível em: Universidad de Sevilla. Biblioteca de la Facultad de Derecho. jabyn@us.es. Acesso em: 2 dez. 2013.
} 
É certo que as penas para aqueles que desrespeitassem essas leis iam do pagamento de ducados proporcionais ao delito até a prisão. Essas penas se estendiam também aos juízes que deixassem de aplicá-las, recebendo as mesmas punições estabelecidas aos réus. Essa utilização indevida de títulos de fidalguia proliferava até nos estamentos mais baixos, resultando que os verdadeiramente nobres recusavam-se a usar seus títulos. (SCHOLBERG, 1979, p. 66)

Acrescenta-se, ainda, que essa pretensa "ascensão social", ciente do anacronismo, não era concebida nos séculos XVI e XVII. Cada súdito, como integrante do corpo político, mantinha-se no estamento a que pertencia, respeitando a hierarquia e a ordem orientadas pela razão de Estado - tudo visando um bem comum. No entanto, o que acontecia efetivamente, segundo Hansen, ${ }^{111}$ era uma "contínua desordem castigada e continuamente recomeçada", pois para o pesquisador:

\begin{abstract}
"Pertencer ao corpo político do Estado implica, por isso, a imediata responsabilidade pessoal para com os demais homens partes dele. Isto só se atinge pela concórdia, coincidência da vontade de todos quanto ao fim do corpo político. Uma vez que pode ser imposta à força, porém, a concórdia não é suficiente, se não houver também a concórdia de cada um consigo mesmo. É preciso reduzir a uma unidade comum da tranquilidade da alma a diversidade dos apetites individuais que concorrem na situação social da concórdia - em outros termos, as paixões dever ser evitadas ou, como são inevitáveis, controladas." (p. 267-268).
\end{abstract}

Assim, a hospedeira, como personagem satírico, representa juntamente com o oficial de justiça a metáfora da discórdia, da desestabilização de uma relação de amizade que visa o bem comum. Retratados na sátira "[...] como evento discursivo:

\footnotetext{
${ }^{111}$ HANSEN, João Adolfo A sátira e o engenho. 2 ed. São Paulo/Campinas: Ateliê Editorial/ Editora da Unicamp, 2004. p. 267-268.
} 
comportamentos, hábitos, atos, gestos, falas”[...], esses personagens reproduzem “o mau funcionamento do corpo político.” (p. 270)

Dessa forma, a "pseudofidalguia" utilizada pela hospedeira tem como propósito, além de vangloriar-se, intimidar a aplicação da lei, levando em conta o ofício “del alguacil"; ao fazer uso desse possível privilégio, a personagem tenta persuadi-lo ao não cumprimento da justiça, mesmo que nesse caso, essa justiça seja aplicada às avessas.

O que se constata é que a hospedeira era conivente com os golpes do oficial de justiça até o instante em que não fosse enredada por eles; a verdade dos acontecimentos estava retratada em sua condição de dona de uma pensão/prostíbulo, sem contar com a postura ridícula que sustenta, baseando-se na suposta posição de esposa de um fidalgo. Nesses termos, a personagem finge ser o que não é, mesmo diante da evidência dos fatos. Segundo Hansen, o néscio finge ser prudente e moderado,

Estilizado negativamente, o pseudodiscreto é identificado na sátira com o pseudofidalgo: embora o critério principal da discrição seja o padrão culto das letras, outros dispositivos operam a desqualificação, como os da genealogia, do nome de família, das virtudes heroicas. Vulgar, o pseudofidalgo figura o tema da decadência política e corrupção dos costumes, que a persona compõe como atos de aparência dos signos nobilitantes [...]. (HANSEN, 2004, p. 95)

Daí o elemento cênico ser a base desse episódio, pois as personagens movimentam-se no palco construído pela narrativa de Berganza; como atores, essas personagens transformam a ação trivial em uma situação cômica com tendências satíricas, pois retratam não somente o ridículo, mas a feiura nociva, que no caso se reproduz nas falhas dessas personagens secundárias. Quando se pensa em nocivo também se entende que essa sátira, censure as práticas sociais por meio da maledicência, da mordacidade. No caso do oficial de justiça, por exemplo, através de seus atos corruptos o personagem transforma a justiça que deveria ser justa em algo 
injusto, ${ }^{112}$ como representante da desarmonia e da desordem social. Nesses termos, para o pesquisador, esse riso expresso

[...] é incidental na sátira, uma vez que ridicularização de vícios é antes uma convenção para várias tópicas graves e vários tipos viciosos que uma correspondência verista e imediata do discurso com a pessoa empírica ou a situação referidas nele. (HANSEN, 2004, p. 294)

Nessa configuração, por meio do discurso da hospedeira são colocados em perspectiva os vícios do oficial de justiça. Assim, se desestabilizam as posições hierárquicas, tudo em prol de interesses particulares. Mesmo espantado diante das falas da hospedeira, o oficial de justiça busca reafirmar sua posição, na tentativa de restabelecer a ordem, embora sua intervenção seja silenciada pela postura ameaçadora da personagem.

BERGANZA. Pasmados quedaron mis amos de haber oído la arenga da huéspeda e de ver cómo les leía la historia de sus vidas, pero como vieron que no tenían de quién sacar dineros, si della no porfiaban en llevarla a la cárcel. (CERVANTES, 2005, p. 686)

O interessante dessa cena é verificar que a partir da atitude assumida pela hospedeira começam a se desencadear reações diversas nos demais personagens; todos, de alguma forma, tentam defender suas posições no interior desse possível entremez. Nesse aspecto, a comicidade se faz presente por meio da ausência de virtude que esses personagens evidenciam, ressaltando que o lugar de privilégio no interior da encenação pertence ao oficial de justiça. Mesmo que as disposições hierárquicas se desestabilizam, por assim dizer, as personagens mantêm suas posições no interior da representação.

\footnotetext{
${ }^{112}$ Idem, comentário feito no Exame de Qualificação em 18 jul. 2013.
} 
BERGANZA. Quejábase ella al cielo de la sinrazón y justicia que la hacían [...] El bretón bramaba por sus cincuenta escuti. Los corchetes porfiaban que ellos no habían visto los follados, ni Dios permitiese lo tal. El escribano, por lo callado, insistía al alguacil que mirase los vestidos de la Colindres [...]. Ella decía que el bretón estaba borracho y que debía de mentir de lo del dinero. [...] todo era confusión, gritos y juramentos [...]. (CERVANTES, 2005, p. 687)

Diante de tanto alvoroço, um corregedor que por ali passava escuta aquela gritaria e decide averiguar o ocorrido.

BERGANZA. Preguntó la causa de aquellas voces; la huéspeda se la dio muy por menudo: dijo quién era la ninfa Colindres, que ya estaba vestida publicó la pública amistad suya y del alguacil, echó en la calle sus tretas y modo de robar, disculpose a sí misma de que con su consentimiento jamás había entrado en su casa mujer de mala sospecha canonizose por santa y a su marido por bendito [...]. (CERVANTES, 2005, p. 687)

De fato, foi tamanho o discurso da hospedeira, sem contar com nova menção da carta de fidalguia, que o corregedor cansado ordena que todos sejam levados à prisão.

BERGANZA. La cual nueva dio con ella el suelo; arañose el rostro, alzó el grito, pero, con todo eso, el teniente, demasiadamente severo los llevó a todos a la cárcel, conviene a saber, al bretón, a la Colindres y a la huéspeda. (CERVANTES, 2005, p. 688)

O que se soube é que tanto o marinheiro quanto a hospedeira pagaram as custas. Colindres saiu livre. No mesmo dia a prostituta "pescó a un marinero con el mismo embuste del soplo", o que levou Berganza a concluir: "[...] porque veas, Cipión, cuántos y cuán grandes inconvenientes nacieron de mi golosina.” (CERVANTES, 2005, p. 688). 
No entanto, o problema não havia sido causado pela gulodice de Berganza, mas de acordo com Cipión: "Mejor dijeras de la bellaquería de tu amo." (CERVANTES, 2005, p. 688).

Com toda a certeza, as ações torpes do oficial haviam desencadeado toda aquela confusão, embora Berganza soubesse que seus atos de vileza jamais acabariam. Mesmo assim, o mastim apresenta certas reservas com respeito à própria narrativa, pois preocupa-se com a honra dos demais oficiais de justiça, já que estaria comprometendo outros que sustentam o mesmo ofício. Diante das reservas do amigo, Cipión declara:

CIPIÓN. Sí, que decir mal de uno no es decirlo de todos; sí, que muchos y muy muchos escribanos hay buenos, fieles y legales, y amigos de hacer placer sin daño de terceros; sí, que no todos entretienen los pleitos, ni avisan a las partes, ni todos llevan más de sus derechos, ni todos van buscando e inquiriendo las vidas ajenas para ponerlas en tela de juicio, ni todos se aúnan con el juez para "háceme la barba y hacerte he el copete", ni todos los aguaciles se conciertan con los vagamundos y fulleros, ni tienen todos las amigas de tu amo para sus embustes. [...] Sí, que no todos como prenden sueltan, y son jueces y abogados cuando quieren. (CERVANTES, 2005, p. 688)

Observa-se nas palavras de Cipión uma ironia implícita por intermédio da repetição da expressão: "no todos", apesar de que enfatize seu desprezo pelo ofício relacionado. Como mencionado, existe uma censura direta ao oficial de justiça feita pela hospedeira, ${ }^{113}$ quando a personagem denuncia a farsa aplicada comumente pelo oficial e seus auxiliares. No entanto, Cipión direciona seu discurso não a uma pessoa em particular, mas a todos que têm o mesmo ofício. Para Antony Close, ao analisar a mesma passagem da novela:

\footnotetext{
113 CLOSE, Anthony. Cervantes y la mentalidad cómica de su tiempo. Madrid: Biblioteca de Estudios
} Cervantinos, 2007. pp. 70-1. 
El fragmento se posiciona, ambiguamente, en un lugar intermedio entre transmitir una censura general y paliarla; y, a este respecto, se trata de una continuación de la escena del alguacil y la Colindres, a la que directamente alude. (p. 71)

Portanto, o que se pode notar nesse momento do "Coloquio" é que, ao retratar as personagens secundárias, Berganza descreve a encenação de cada uma delas no interior desse grande "teatro do mundo", ${ }^{114}$ em que as ações introduzidas de forma teatralizada procuram imitar o modelo de pessoas empíricas, visando o reconhecimento do leitor.

Assim, as personagens, através da exposição que Berganza faz de seus ofícios, instituem uma imagem de aparência e posição, remetendo à identidade pela representação, seja de virtudes ou vícios.

No caso da novela, os tipos apresentados são pecadores e estariam relacionados à fealdade moral associada à falta de medida ou proporção, que segundo Hansen ${ }^{115}$, ao analisar o Tratado dos ridículos de Emanuele Tesauro, os torna substituíveis devido aos conceitos associados ao pior e ao péssimo (p. 245). A exposição ridícula e maledicente desses personagens será responsável pela produção dos efeitos de comicidade no interior dessa novela exemplar. No caso do oficial de justiça, suas práticas desonestas retratam o feio, o torpe, isto é, o cômico demonstrado por intermédio de suas características corruptas, cuja representação se dá ora pelos vícios apresentados, ora pelos crimes que o oficial de justiça comete. Entretanto, as ações criminosas desse homem não param, afinal, "más alto picaba mi amo", como diria Berganza, pois o personagem se valerá de outras artimanhas, como se verá mais à frente.

\footnotetext{
${ }^{114}$ El gran teatro del mundo (1655), composta por Calderón de la Barca no século XVII. O tema que se articula nesse auto diz respeito à vida humana vista como um grande teatro em que cada pessoa representa seu papel. A vida humana como um teatro é uma tópica que vem desde a Antiguidade com os filósofos pitagóricos, em Filebo de Platão, na obra dos estoicos, especialmente, nas Epístolas morais a Lucilio de Sêneca, bem como na obra Encheiridion do filósofo grego Epicteto. Este último, em particular, serviu de modelo para a difusão da imagem do theatrum mundi no Renascimento.

${ }^{115}$ HANSEN, João A. La doctrina conceptista de lo cómico en el "Trattato De'Ridicoli" de Emanuele Tessauro. Disponível em: http://bidi.unam.mx/libroe_2007/01042713/A16.pdf. Acesso em: 23 out. 2012.
} 


\section{Outras artimanhas do oficial de justiça - "creció la fama de mi cobarde"}

Quien quiere mentir, engaña y el que quiere engañar, miente.

Mateo Alemán

Como visto no subcapítulo anterior, Berganza se coloca a serviço de um oficial de justiça, transformando-se em "perro de ayuda", ou seja, por ser grande e forte era treinado para defender seu amo, bem como acompanhá-lo nas rondas que fazia pela cidade. ${ }^{116}$ Durante as diligências, as manobras desonestas do oficial de justiça não cessavam, pois sempre havia um marinheiro desavisado, que em busca de companhia e divertimento acabava se convertendo em uma presa fácil desse homem e de seus comparsas. No entanto, Berganza alerta o amigo Cipión, dizendo que as vilezas do amo não se restringiam aos golpes praticados conforme o fragmento abaixo:

BERGANZA. Más alto picaba mi amo; otro camino era el suyo; presumía de valiente y de hacer prisiones famosas; sustentaba la valentía sin peligro de su persona, pero a costa de su bolsa. [...] Un día acometió en la Puerta de Jerez él solo a seis famosos rufianes, sin que yo le pudiese ayudar en nada, porque llevaba con un freno de cordel impedida la boca (que así me traía de día, y de noche me le quitaba). Quedé maravillado de ver su atrevimiento, su brío y su denuedo; así se entraba y salía por las seis espadas de los rufos como si fueran varas de mimbre [...]. (CERVANTES, 2005, p. 689)

Por intermédio das ações do oficial de justiça descritas por Berganza, sustentar uma reputação de valente, fingindo aplicar a justiça em prol do bem da sociedade era algo conveniente para o personagem, levando em conta a representação que fazia de si,

\footnotetext{
116 CERVANTES, Miguel de. "El coloquio de los perros" in Novelas ejemplares. Barcelona: Crítica, 2005. Extraído da nota de rodapé p. 682.
} 
visando o conceito favorável que lhe seria atribuído pela opinião alheia - um modelo de conduta muito presente na sociedade dos séculos XVI e XVII. Nesses termos, ao verificar atentamente essa passagem do "Coloquio", nosso interesse está em analisar esse tipo de encenação apresentada pelo antagonista, considerando a necessidade de um maior aprofundamento das técnicas de fingimento: ${ }^{117}$ dissimulação e simulação, apropriadas por alguns homens como "modelo de representação tensa e conflitiva de posições hierárquicas", conforme João A. Hansen (p. 136).

Nesse contexto, para melhor compreender como se configuram nos séculos XVI e XVII tais técnicas, deve-se observar que ambas estão direcionadas a representar uma aparência adequada, omitindo ou faltando com a verdade. Um modo mais fácil de se entender essas questões consiste em verificar as diferenças existentes entre as condutas de nossa sociedade contemporânea e a sociedade cortesã daquele período. Por exemplo, ao tratar a primeira, pode-se notar que a mesma estabelece distinções a respeito do que é público e privado, isto é, um governante do nosso tempo não compartilha, tanto com o público quanto com aqueles que não possuem cargos para tais competências, determinados assuntos, sejam voltados à sua vida pessoal, sejam confidenciais, referentes às próprias atribuições políticas.

Na sociedade cortesã, ao contrário, todos ao redor do rei compartilhavam de sua intimidade, embora os súditos soubessem respeitar seu lugar no interior desse corpo político, na hierarquia. Porém, tudo nesse antigo regime era velado, dissimulado e simulado sempre visando determinados fins. Seria, como diria Maria Augusta da Costa Vieira, "o protocolo"118, a expressão mais significativa dessa sociedade, em que

\footnotetext{
${ }^{117}$ HANSEN João A. "Educando príncipes no espelho". Disponível em: http://periodicos.uesb.br/index.php/floema/article/view/81,pdf. Acesso em: 3 jan. 2013 118 VIEIRA, Maria Augusta da C. A narrativa engenhosa de Miguel de Cervantes. São Paulo: Edusp, 2012. pp. 233-4.
} 
palavras, gestos e vestimentas se interpõem nas relações sociais. Além disso, segundo a pesquisadora,

[...] para a sociedade de corte, todo o protocolo, que constitui um verdadeiro código de civilidade, constitui um indicador extremamente sensível e significativo de seus valores e de sua estrutura de relações. (VIEIRA, 2012, p. 234)

O que leva a considerar que o cerimonial e a etiqueta ${ }^{119}$ tornam-se $^{1}$ imprescindíveis na compreensão da estrutura de funcionamento da sociedade cortesã, bem como de cada indivíduo que a integra, ao contrário da nossa sociedade contemporânea, em que tais práticas ocupam um lugar de menor importância em sua escala de valores (p. 234). Para Maria Augusta da Costa Vieira, baseando-se nos estudos de Norbert Elias, essas práticas evidenciam “[...] importantes instrumentos de dominação e de distribuição do poder, que regulavam a vida em suas diferentes instâncias.” (p. 234).

Conhecedor desses procedimentos, o homem cortesão se qualifica por “dispor de uma perspicácia refinada para observar a fala, os gestos, o comportamento adequado de cada indivíduo", segundo a ordem a que pertence no interior dessa sociedade (p. 234).

Essa perspicácia refinada pode ser percebida em um dos atributos de um secretário real, por exemplo, no momento em que possui conhecimento suficiente para compreender a vontade de seu soberano, muitas vezes convertida em "conceitos e cifras", preservando-a da "indiscrição cortesã ou da argúcia do adversário político"120. Daí a necessidade de se utilizar técnicas de dissimulação e simulação, como uma arte de se ocultar a verdade ou de fingimento, tanto no que se refere à política monárquica quanto à representação empregada nas ações públicas.

\footnotetext{
${ }^{119}$ Idem, p. 234

${ }^{120}$ ACCETTO, Torquato. Da dissimulação honesta. Apresentação de Alcir Pécora. São Paulo: Martins Fontes, 2001. p. X.
} 
Nessa configuração, o conceito de dissimulação pode ser entendido como "uma técnica básica de ocultar ou adiar a verdade, mas não de produzir a mentira" ${ }^{121}$ (ACCETTO, 2001, p. XX). Contudo, a simulação consiste em fingir o que não é; voltada à trapaça, ao engano, a simulação funda-se em mentir os feitos, expressando algo falso por intermédio de obras ou signos exteriores, conforme diria no século XIII Santo Tomás de Aquino ${ }^{122}$ (p. XXI).

Assim, a simulação se dá por meio das ações externas que encobrem a verdade dos feitos, fazendo uso da mentira. Para Mario Prades Vilar ${ }^{123}$, em seu artigo intitulado "La teoría de la simulación de Pedro de Ribadeneyra y el maquiavelismo de los antimaquiavélicos", que analisa El tratado del príncipe cristiano escrito pelo jesuíta em 1595, no trecho que faz alusão ao uso da simulação, Ribadeneyra reitera o caráter ilícito da mentira e a define em termos agostinianos:

San Agustín y otros santos doctores enseñan que la mentira siempre es pecado, y que por ninguna cosa del mundo se debe mentir, ahora sea de palabra, que propiamente se llama mentira, ahora con obras y señales exteriores, que llaman simulación. La simulación es, por tanto, la forma gestual de la mentira. (p. 144)

Entretanto, retornando a essa passagem do "Coloquio", qual a relação desses conceitos, utilizados por governantes, cortesãos discretos, com um oficial de justiça, corrupto? Na realidade, como se verifica, a novela pode ser percebida como representação burlesca dos vícios humanos que tanto podem se configurar na plebe quanto no ambiente de corte. Desse modo, o oficial de justiça representa um desvio da

\footnotetext{
${ }^{121}$ Idem, p. XX.

${ }^{122}$ AQUINO, Santo Tomás de. Suma teológica. Disponível em: http://hgj.com.ar/sumat/c/c111.html\#a1. Acesso em: 18 mar. 2014.

${ }^{123}$ VILAR, Mario Prades. "La teoría de la simulación de Pedro de Ribadeneyra y el maquiavelismo de los antimaquiavélicos". Disponível em: http://dx.doi.org/10.5209/rev_INGE.2011.n5.36222 pdf. Acesso em: 6 mar. 2014.
} 
aplicação dessa justiça, retratado por meio da narrativa de Berganza, cuja censura manifesta irá transitar entre o ridículo e a maledicência.

Nessa configuração, pode-se perceber no fragmento a intenção do amo de Berganza em mostrar uma aparência relacionada à valentia, em um tempo, como já mencionado, em que o homem não era valente, honrado etc., mas possuía qualidades que lhe eram concedidas por aqueles que nem sempre sustentavam tais atributos.

Daí a necessidade de o personagem utilizar-se da simulação para conseguir a aprovação social; até mesmo Berganza, em um primeiro momento, consegue ser enganado por meio dessa farsa:

BERGANZA. [...] era cosa maravillosa ver la ligereza con que acometía, las estocadas que tiraba, los reparos, la cuenta, el ojo alerta que no le tomasen las espaldas. Finalmente, él quedó en mi opinión y en la de todos cuantos la pendencia miraron y supieron por un Rodamonte $^{124}$ [...]. (CERVANTES, 2005, p. 689)

O que se pode notar nesse instante da novela é a atitude teatral assumida pelo oficial de justiça; a destreza com que lutava contra os rufiões da cidade fazia com que todos o tivessem por um herói, homem virtuoso e valente, embora tudo não passasse de uma encenação, de uma mentira. Acrescenta-se, ainda, que a simulação como técnica de fingimento era utilizada, também, no entremez; ao protagonizarem personagens tipo tais como: alcoviteiras, soldados covardes, rufiões, prostitutas etc., seus atores instituíam a representação cômica do vício. Para Eugenio Asensio, em seu livro Itinerário del entremés, ao citar a obra de Fernando de Rojas, afirma:

Del mundo inferior, del subsuelo de la sociedad saltaban a plena luz del arte criaturas amasadas de vileza, concupiscencia y engaño, no como mero coro de los amos, sino ocupando con aplomo el centro del

\footnotetext{
${ }^{124}$ Personagem de Orlando enamorado de Mateo Boiardo e de Orlando furioso de Ludovico Ariosto. Guerreiro sarraceno de grande orgulho e força sobre humana. Extraído da nota da edição de Jorge García López, p. 689.
} 
tablado. Esta incitación ha sido más fértil en resultados que la simple imitación. Sin que por ello quitemos importancia a la deuda que el entremés ha contraído al heredar de Fernando de Rojas mediata o inmediatamente, un arsenal de gracejos, motivos y tipos. De los motivos el más fecundo y ejemplar ha sido el motivo del honor en la infamia, de la simulación del pundonor en medio de la deshonra. (p. 30)

No caso desse episódio do "Coloquio", visto anteriormente neste trabalho como um pequeno entremez, pode-se verificar que as ações simuladas do oficial de justiça, no sentido de aparentar uma "pseudovalentia", têm como propósito encobrir as próprias faltas, do contrário estas o direcionariam à desonra. Como resultado, as pessoas o viam como herói:

BERGANZA. Miraban a mi amo por las calles do pasaba, señalándole con el dedo, como si dijeran: “Aquél es el valiente que se atrevió a reñir solo con la flor de los bravos de la Andalucía". En dar vueltas a la ciudad, para dejarse ver, se pasó lo que quedaba de día [...]. (CERVANTES, 2005, pp. 689-90)

A exposição de seus feitos era necessária para que recebesse do povo o reconhecimento merecido por seus "atos de bravura". No entanto, essas ações se passavam durante o dia, mas à noite, seguro de que ninguém o visse, o oficial de justiça se encontrava com todos os rufiões que participaram da encenação, diante do olhar incrédulo de Berganza:

BERGANZA. [...] hallamos en un patio a todos los jayanes de la pendencia, sin capas ni espadas, y todos desabrochados; y uno, que debía de ser huésped, tenía un gran jarro de vino en la una mano y en la otra una copa grande de taberna, la cual, colmándola de vino generoso y espumante, brindaba a toda la compañía. Apenas hubieron visto a mi amo, cuando todos se fueron a él con los brazos abiertos, y todos le brindaron, y él hizo la razón a todos [...]. (CERVANTES, 2005, p. 690) 
Por intermédio desse fragmento, é incontestável a relação de cumplicidade estabelecida entre os rufiões da cidade e o amo de Berganza, afinal, como em uma grande comemoração após um espetáculo bem sucedido, os atores se confraternizavam, desfilando seus feitos, orgulhosos da excelente representação. Para a cidade, o oficial era um bravo, um homem virtuoso que havia enfrentado seis famosos ladrões, embora tudo não passasse de uma mentira, uma farsa paga pelo próprio oficial. Berganza a tudo assistia, observando com que animação e orgulho narravam seus casos e feitos, conforme o parágrafo abaixo:

BERGANZA. Quererte yo contar ahora lo que allí se trató, la cena que cenaron, las peleas que se contaron, los hurtos que se refirieron, las damas que de su trato se calificaron y las que se reprobaron las alabanzas que los unos a los otros se dieron, $[\ldots]$ y, finalmente, el talle de la persona del huésped, a quien todos respetaban como a señor y padre, sería meterme en un laberinto donde no me fuese posible salir cuando quisiese. [...] vine a entender con toda certeza que el dueño de la casa, a quien llamaban Monipodio, era encubridor de ladrones y pala de rufianes [...]. (CERVANTES, 2005, pp. 690-1)

Líder da "hampa sevillana" 125 de rufiões, delinquentes e prostitutas, Monipodio faz sua primeira aparição como uma das personagens da novela exemplar Rinconete y Cortadillo; nessa novela será descrito um dia de sua vida, com Monipodio concedendo audiências e discutindo os preços de negócios criminosos com seus clientes, que podem ser oficiais de justiça ou ladrões.

[...] la parte central del relato puede leerse como un día de la vida de Monipodio; concede audiencia, reparte justicia entre sus súbditos (como son Repulido y Cariharta), discute con sus clientes el montante

\footnotetext{
${ }^{125}$ LÓPEZ, Jorge García. "La Obra - En torno a las Novelas" In: Prólogo das Novelas Ejemplares Miguel de Cervantes. p. 34.
} 
de sus "servicios" y, en fin, pasa revista y actualiza los asientos contables del negocio criminal ${ }^{126}$.

Igualmente, nesse momento da novela verifica-se a presença de um oficial de justiça. Personagem mencionado pelo chefe dos ladrões, sua aparição se dá na passagem em que Cortadillo havia roubado de seu parente, um sacristão, uma bolsa contendo "quince escudos de oro y dos reales de a dos y no sé cuántos cuartos [...] (p. 265). Dessa forma, o oficial, sem seus beleguins, se dirige à casa de Monipodio para reaver a bolsa e todo o seu conteúdo. Furioso, o chefe dos ladrões cobra do responsável pelos furtos na praça de San Salvador o referido objeto, apesar de o jovem não ter conhecimento de quem o tenha roubado.

\footnotetext{
¡ Nadie se burle con quebrantar la más mínima cosa de nuestra orden, que le costará la vida! Manifiéstese la cica, y si se encubre por no pagar los derechos, yo le daré enteramente lo que le toca, y pondré lo demás de mi casa, porque en todas maneras ha de ir contento el alguacil. (CERVANTES, 2005, p. 265)
}

Quando Cortadillo devolve a bolsa para que seja entregue ao oficial, Monipodio, satisfeito, cita o seguinte refrão: "No es mucho que a quien te da la gallina entera, tú des una pierna della”. (p. 266)

De maneira idêntica, retornando ao "Coloquio", fica evidente que além das relações de cumplicidade estabelecidas entre o oficial de justiça e Monipodio com respeito aos seus falsos atos de bravura, havia também uma troca de favores entre ambos, conforme o fragmento abaixo:

BERGANZA. [...] con todo cuanto Monipodio dijo que había costado la cena, $[\ldots]$ fue su postre dar soplo a mi amo de un rufián forastero que [...] debía de ser más valiente que ellos y de envidia le soplaron. Prendiole mi amo la siguiente noche, desnudo en la cama, que, si

\footnotetext{
${ }^{126}$ Idem, p. 34.
} 
vestido estuviera, yo vi en su talle que no se dejara prender tan a mansalva. Con esta prisión, creció la fama de mi cobarde, que era mi amo más que una liebre [...]. (CERVANTES, 2005, p. 691)

Nota-se que a iconografia nesse período percebe a lebre não somente como um animal de mau agouro, mas também como símbolo de covardia. Em seu artigo sobre o episódio da lebre e a jaula dos grilos em Dom Quixote II, 73, Francisco L. Ranz ${ }^{127}$ cita Cesare Ripa e sua obra Iconología. Ao falar sobre a lebre, Ripa afirma que os soldados medrosos que fugiam recebiam o nome de Lepores galeatos, ou seja, lebres com casco. O encontro de um indivíduo com uma lebre pelo caminho, segundo o autor, também pode designar que o caminhante tem uma natureza amedrontada.

Además, las gentes que son cobardes y supersticiosas, cuando van de camino, si se encuentran con alguna liebre la suelen considerar de mal agüero, teniendo su aparición como un mal encuentro [...]. (Ripa II, 341, p. 228)

Assim, nesse episódio do "Coloquio", ironicamente, Berganza não deixa de censurar tanto os atos de vileza de seu amo quanto sua própria natureza torpe. Além disso, a necessidade do oficial de justiça em obter a aprovação pública irá conduzir a própria representação, conseguindo com isso a admiração de todos.

Nesse sentido, a narrativa do protagonista remete a um tema de cunho satírico, como é o caso da corrupção presente em determinados ofícios tais como: juízes, oficiais de justiça, escrivães etc., apesar de que, como se escreveu anteriormente neste trabalho, Cervantes apresenta algumas reservas com relação ao uso da sátira, o que não foi motivo de excluí-la vigorosamente de seu discurso. É possível acrescentar, ainda, no que concerne à sátira cervantina, a inexistência de um direcionamento com respeito à correção dos vícios, pois sem julgamentos ou penalidades ela procura dar conta do

\footnotetext{
${ }^{127}$ RANZ, Francisco Layna. "Una decisiva anécdota para entender el episodio de la liebre y la jaula de grillos ( $D Q$ II, 73)". Disponível em: http://www.ehumanistas.ucsb.edu/Cervantes/volume\%201/120layna.pdf. Acesso em: 19 maio 2014.
} 
presente ao expor a imprudência do personagem, bem como a falta de juízo retratada em suas ações.

Com isso, a representação do antagonista faz com que o olhar alheio não alcance a verdade dos fatos, mas a perfeita encenação, condutora da imagem simulada que descarta o pecado e enaltece a falsa virtude. O parecer torna-se elemento constitutivo nesse momento da novela, pois o olhar público só se detém na aparência, excluída totalmente a essência. Como nos faz ver João A. Hansen, ${ }^{128}$ a sátira

Como subgênero do cômico, ensina: a persona se constitui como mestre do público, pois depende de seus avisos o ensinamento do que expõe. Mais que ensinar ou agradar, porém, ela quer mover: o mestre procura que o público tire escarmento e não exemplo das ações más, exemplo e não escarmento das boas. (HANSEN, 2004, p. 200)

Em certa medida é o que faz Berganza, ou seja, expõe as ações de seu amo a fim de mover os afetos de seu destinatário, o leitor, que por intermédio dos casos relatados reconhece sua natureza e percebe a burla. Com isso, o narrador obtém a cumplicidade e o deleite esperados, tendo em vista a causa que move (p. 200).

Nessa linha, vícios ou desproporções do personagem estarão em concordância com seus atos, o gênero, a natureza e o nome de cada um (p. 199). Em outras palavras, todas as ações expostas por Berganza com respeito ao amo se encontrarão em conformidade com o gênero do vício, no caso, a injustiça, a corrupção, com os atos e seus nomes: simulação, aparência, a mentira, conferindo para o personagem uma natureza ridícula e viciosa. (p. 200).

128 HANSEN, João Adolfo. “A proporção do monstro". In: A sátira e o engenho. 2 ed. São Paulo/Campinas: Ateliê Editorial/ Editora da Unicamp, 2004. 
Mesmo com todos os atos de vileza do amo de Berganza, suas ações não passam de mais algumas peripécias na vida do jovem mastim. O que apresenta Antony Close ${ }^{129}$ em seu artigo Algunas reflexiones sobre la sátira en Cervantes é que o autor do “Coloquio", com relação à sátira, se mostra com certo escrúpulo de ordem estética; ao comparar com o tom didático e muito censor, aos moldes de Guzmán de Alfarache, acrescenta que sua utilização não seria conveniente a uma obra cômica de "estilo llano y tom festivo", cujo fim principal está em incitar o riso dos leitores (p. 496). Entretanto, o didatismo é inerente à sátira, o que leva Close a questionar com respeito à sua utilização, bem como os limites que estabelece com o gênero cômico no “Coloquio":" ¿Hasta qué punto, pues, debe admitirse en una novela como "El coloquio de los perros", novela que está a caballo entre los dos géneros?” (p. 496).

O que leva o estudioso afirmar que o "Coloquio" faz uso do gênero cômico, pois ora o emprega com amenidade e cuidado no trato dos vícios, ora o utiliza como discurso satírico ao instituir, por intermédio do diálogo entre Cipión e Berganza, uma censura moral com um tom algumas vezes didático. Para Close, o interesse de Cervantes não está em focar a atenção dos leitores somente nas faltas e disparates sociais, mas em forjar um destino individual, em que os crimes cometidos pelos personagens secundários repercutam em uma lição proveitosa ou em um fenômeno contemplado de fora (p. 504).

Dessa forma, Cervantes desvia-se da mordacidade comumente verificada em alguns discursos satíricos, aos moldes de Quevedo, porque, segundo Close, não se encontra no autor de Dom Quixote nada parecido à repugnante tendência escatológica quevediana, nem ao menos à intromissão audaciosa do autor na política internacional e controvérsias religiosas daqueles tempos (p. 499).

\footnotetext{
${ }^{129}$ CLOSE, Antony. Algunas reflexiones sobre la sátira en Cervantes. In: Nueva Revista de Filología Hispánica, Centro de Estudios Lingüísticos y Literarios, Tomo XXXVIII. México: 1990.
} 
Nessa configuração, a título comparativo, extraiu-se da obra de Quevedo Los Sueños ${ }^{130}$ um fragmento do tratado dedicado ao conde de Lemos intitulado El Alguacil Endemoniado. No contexto, o cônego calabrês procura extrair do corpo de um oficial de justiça um demônio que ali se encontrava. O narrador pergunta ao cônego o que significava tudo aquilo, uma vez que o oficial apresentava movimentos frenéticos:

- Un hombre endemoniado - y al punto, el espíritu que en él tiranizaba la posesión a Dios, respondió:

- No es hombre, sino alguacil. Mirad cómo habláis, que en la pregunta del uno y en la respuesta del otro se vee que sabéis poco. Y se ha de advertir que los diablos en los alguaciles estamos por fuerza y de mala gana; por lo cual, si queréis acertar, debéis llamarme a mí demonio enaguacilado, y no a éste alguacil endemoniado. [...] ¿Quién podrá negar que demonios y alguaciles no tenemos un mismo oficio, pues bien mirado nosotros procuramos condenar y los alguaciles también; nosotros que haya vicios y pecados en el mundo, y los alguaciles lo desean y procuran con más ahínco [...]. (QUEVEDO, 1995, p. 45)

Ao observar com atenção o fragmento acima, vê-se claramente a mordacidade e a falta de amenidade quevediana, características não encontradas nos textos cervantinos, aos moldes da novela "El coloquio de los perros". Consequentemente, por Cervantes apresentar em alguns de seus escritos certa tendência sociomoral, mais comedida e sóbria, sua narrativa se institui por vezes menos divertida, porém com passagens propositalmente equívocas carregadas de muita ironia. (p. 500). Assim, para Close a atitude cervantina difere do ceticismo de Quevedo, “fruto de un estoicismo desengañado y prejuicios nobiliarios" (p. 500).

[...]desde esta perspectiva, se contempla toda la vida social como una amarga farsa regida por la codicia y las falsas apariencias. Y en cuanto al honor y la jerarquía falsificados - tema obsesivo en Quevedo, que

${ }^{130}$ QUEVEDO. Francisco de. Los Sueños. PML Ediciones, 1995. pp. $42-57$. 
abarca figuras y tópicos como el caballero chanflón, el converso, el dinero que todo lo corrompe [...]. (p. 500)

Nesses termos, para o pesquisador, evidencia-se o tom moderado de Cervantes que, em certa medida, se afasta de muitos autores satíricos de seu tempo. Daí a inexistência nos textos cervantinos de uma extrema indignação, de um tom bufão e insultante, da obscenidade, da deformação grotesca de tipos ridicularizados, de um jogo verbal que desmascara abusos disfarçados pelas aparências convencionais (p. 500).

Por tudo isso, pode-se concluir que o oficial de justiça retrata a corrupção nos meios judiciais, pois apresenta uma justiça falha e isso "fere a harmonia preestabelecida na hierarquia". Ao instituir certa relação de parceria com os ladrões e rufiões da cidade, o oficial consegue, com a ajuda desses, encenar todo um espetáculo, cujo propósito está em disseminar, em meio à opinião pública, a farsa, a simulação de ações e virtudes inexistentes no personagem. A imagem que persuade se torna fundamental nesse instante da novela, pois o olhar alheio capta tais figurações e as converte em honra, valentia, embora as ações sejam retratadas de maneira enganosa. O público e até certo ponto Berganza não deixam de ser cúmplices do personagem, à medida que aceitam o fingimento, sem questionamentos, de forma convencional. Dessa maneira, se introduz o grande teatro do mundo ou "o mundo como um grande teatro"131, pois conforme Hansen $^{132}$ :

$\mathrm{Na}$ ordenação dupla, teatralizam-se a desonestidade, a tolice, a hipocrisia, a desmedida, em várias instituições e ocasiões; simultaneamente, a honra, o juízo, a verdade, o equilíbrio. Assim, a sátira é sempre dupla quanto ao seu efeito de sentido, afirmando uma ausente plenitude do bem comum, identificada com a boa política e a

\footnotetext{
${ }^{131}$ GUINSBURG, J. "Diálogos sobre teatro". In: A consciência do espetáculo, no espetáculo da consciência. Org. de Armando Sérgio da Silva. São Paulo: Ed. Edusp, 2002. (p. 232).

${ }^{132}$ HANSEN, João A. A sátira e o engenho. 2 ed. São Paulo/Campinas: Ateliê Editorial/ Editora da Unicamp, 2004.
} 
boa religião, oposta à decadência do presente mau e corrupto, negado como teatro da falha, falta e culpa. (HANSEN, 2004, p. 201) 


\section{O oficial de justiça - "el burlador burlado"}

La risa es salud y alegría, la burla es crueldad y amargura.

Jacinto Benavente

Quando se considera alguns temas cômicos constantes nas obras dos séculos XVI e XVII, há que se refletir com respeito à origem desses temas. Provenientes geralmente da tradição antiga e do folclore popular, essas tópicas, ao serem representadas para o público, colocavam em cena verdadeiras práticas argumentativas, cujo intuito estava em ridicularizar seu destinatário de maneira eficiente. Dessa forma, o objetivo dessas composições cômicas estava em persuadir o público por meio de um espetáculo que degradava seu alvo, transformando-o em matéria de riso.

Assim, as representações do cômico, sejam voltadas à benevolência, sejam apresentando um discurso mordaz, como é o caso da sátira, instituíam temas que exaltavam tanto a sexualidade feminina quanto questões políticas e religiosas (CLOSE, 1990, pp. 499-500). Esses motivos observados no cotidiano das sociedades do século XVII chegaram a consagrar alguns autores, tais como Aristófanes ${ }^{133}$ na Grécia Antiga (447 a.C. - c. 385 a.C) e Boccaccio na Itália (1313-75), como se verá mais adiante.

Nessa configuração, perseguindo as ações que se desenvolvem na vida cotidiana, nos estamentos sociais mais baixos, o que será apresentado a seguir é a observância do tema "del burlador burlado" no final do episódio referente ao oficial de justiça na novela exemplar "El coloquio de los perros", na passagem em que o cão Berganza relata mais uma de suas peripécias.

\footnotetext{
${ }^{133}$ SCHERE, María Jimena. "El tópico del burlador-burlado en los caballeros de Aristófanes". Disponível em: http://www.revistas.unam.mx/index.php/nova_tellus/article/view/36726. Acesso em: 2 jun. 2014.
} 
Perseguindo essa linha interpretativa, ao tratar do tema "del burlador, burlado", é importante rever alguns autores que abordaram essa tópica em suas obras, a começar pela doutrina antiga. Dentre os comediógrafos pertencentes à tradição grega, Aristófanes $^{134}$ se destaca, em especial, por satirizar políticos, bem como membros destacados da sociedade de seu tempo. Com discursos satíricos mordazes, o autor colocava em cena a deformidade moral dos "personagens-alvo", como é o caso de sua peça Los Caballeros, cujo tema "del burlador burlado" tem como destinatário o líder político Cleón, "símbolo de una demagogia negativamente valorada, devuelve a Demos su antigo esplendor" ${ }^{\text {"135 }}$.(STARK, 1993, pp. 29-30).

Nesse aspecto, o tema “del burlador burlado", conforme os estudos de María Jímena Schere ${ }^{136}$ em seu artigo "El tópico del burlador burlado en los caballeros de Aristófanes", surge por intermédio de dois personagens antagonistas: o primeiro representando a figura do herói astuto e vitorioso; o segundo através do enganador e trapaceiro que tenta enganar o herói, mas termina vencido pela inteligência de seu oponente, convertendo-se em "burlador burlado" (p. 21).

Entretanto, a pesquisadora alerta com respeito aos excessos de estudos comparativos sobre o tema, pois o enganador/trapaceiro pode ser percebido de maneiras

\footnotetext{
${ }^{134}$ Pode-se dizer que a primeira tradução da obra completa de Aristófanes, diretamente do grego para a língua castelhana, foi feita por Federico Baráibar y Zumárraga (1ª edição 1880-1). Entretanto Menéndez Pelayo sugere que José Antonio Conde tenha traduzido Lisístrata (Biblioteca de Traductores Españoles, Santander, 1952, vol. I, pp. 360-1). Don Pedro Estala traduziu uma comédia de Aristófanes: El Pluto. (Comédia de Aristófanes, traduzida do grego em verso castelhano). Com um Discurso Preliminar sobre La Comedia Antigua y Moderna, por D. Pedro Estala, Presbítero, Madrid en la Imprenta de Sancha Año MDCCXCIV (1794). Trecho extraído do artigo de González González, Marta, "La censura en las traducciones de los clásicos griegos. El ejemplo de Platón y Aristófanes". Disponível em: http://ddd.uab.cat/pub/faventia/02107570v29n1/02107570v29n1p77.pdf . Acesso em: 11 jun. 2014.

${ }_{135}$ GIL, Luis. La comicidad en Aristófanes.

Disponível em: http://revistas.ucm.es/index.php/CFCG/article/view/CFCG9393110023A pdf. Acesso em: 12 ago. 2011.

136 SCHERE, María Jimena. "El tópico del burlador-burlado en los Caballeros de Aristófanes". Disponível em: http://www.revistas.unam.mx/index.php/nova_tellus/article/view/36726. Acesso em: 2 jun. 2014.
} 
distintas, devendo-se levar em conta a sociedade em que se insere, bem como as diferentes culturas e gêneros (pp. 21-2).

Um exemplo disso pode ser verificado na percepção do personagem na cultura grega. Visto como herói esperto e triunfante, em alguns casos, o enganador possui habilidades que o tornam tanto apto para a guerra, quanto para assuntos de amor e comércio (p. 22). Nesse momento, a pesquisadora cita o exemplo do canto IX da Odisseia de Homero, quando o herói Odisseu vence o ciclope Polifemo, que como burlador burlado possui características que o tornam inferior em comparação ao protagonista seja em astúcia, seja em qualidades morais (p. 23).

Além disso, ao verificar a presença do tema no gênero das fábulas gregas, Schere relata que os valores referentes à força e astúcia são observados, como também a atitude enganosa de um personagem que ao adotar, por exemplo, uma identidade falsa, tem como intuito enganar aqueles tidos como mais fracos. É o caso da fábula $L a$ comadreja y las gallinas. ${ }^{137}$

Una comadreja, luego de haber oído que en una granja las gallinas estaban enfermas, disfrazándose de médico y tomando los instrumentos necesarios de esta ciencia, se presentó y, deteniéndose ante la granja, les preguntó cómo estaban. Y ellas respondieron: "Bien, si tú te marchas de aquí". (SCHERE, p. 24)

No instante em que as aves descobrem a mentira da doninha, ao querer passar-se por médica, enganam a oponente. No final, a doninha assume a posição de enganadora enganada.

Seguindo esses parâmetros, Schere, ao citar os estudos de Rodríguez Adrados e García Gual, acrescenta que apesar dos valores de força e esperteza percebidos na fábula, é importante ressaltar que em comparação com o modelo épico, cujo tema se 
centra na figura do herói, os personagens do gênero fabular encarnam o "homem comum" que se vê representado por intermédio da figura de animais, pois "La fábula, entonces, desprende el tópico del espacio mitológico y lo lleva al ámbito mundano de la vida cotidiana, el mismo ámbito en el que suele desarrollarse la acción de la comedia antigua." (p. 26).

Tendo em vista essa perspectiva, a autora observa que a partir do emprego da fábula, os poetas jâmbicos utilizaram o gênero como recurso "argumentativo polêmico, a fim de investir contra seu inimigo pessoal”. Assim, a partir da utilização da fábula, o jambo incorpora e reelabora o tema "do enganador enganado" (p. 26), conforme o exemplo da fábula esópica "La zorra y el mono discuten por su prosapia".

Una zorra y un mono que hacían juntos el camino a propósito de su prosapia discutían. Y mientras cada uno iba exponiendo con detalles muchas glorias, llegaron ante unas tumbas. El mono clavó sus ojos en ellas y se puso a lamentarse. Al preguntar la zorra la causa, el mono, señalándole los sepulcros, dijo: "Pero cómo no he de llorar al ver las estelas de mis mayores, de os que fueron libertos y esclavos". Y la zorra dijo: "Pues miente lo que quieras, porque ninguno de ellos va a levantarse para desmentirte". (ESOPO, 2008, p. 10)

Para Adrados, citado por Schere, a raposa coloca em aberto o engano, zombando de seu companheiro, afinal o macaco procurou, através de uma mentira, provar uma origem ilustre que não possuía. A ação não lhe serviu de nada - o macaco enganador acabou enganado. "En este epodo, la zorra astuta se identificaría con la propia figura del ‘yo lírico’, mientras que el mono burlado representa al adversario del poeta.” (p. 27)

Outro exemplo da tópica pode ser encontrado em Tito Marcio Plauto (230-180 a.C.). Dramaturgo romano responsável por criar personagens tipos imitados tanto por autores de seu tempo quanto por autores modernos, Plauto foi estudioso da comédia nova de Menandro (342-291 a.C.), cujos personagens, ao fazerem uso de máscaras, 
retratavam suas características no instante em que atuavam (p. 64). É oportuno ressaltar que esse tipo de comédia não deixa de ser devedor da comédia antiga grega, a qual tem como referência mais destacada o comediógrafo Aristófanes. De acordo com Alfonso Martín Jiménez" 138 em seu artigo "Burladores y engañados en la comedia europea; La comedia de los asnos, de Plauto, La mandrágora, de Maquiavelo y Las alegres casadas de Windsor, de Shakespeare", o pesquisador afirma que:

[...] mientras que las antiguas comedias solían reflejar problemas sociales de importancia, las obras de la Comedia Nueva, cuyo fin principal es la evasión, prefieren poner en escena los problemas más cotidianos de los atenienses, y se valen de equívocos y engaños para crear situaciones humorísticas que terminan con un final feliz en el que se restablece el orden turbado. (JIMÉNEZ, 1999, p. 64)

Conforme Martín Jiménez, as comédias de Plauto ${ }^{139}$ são obras que descrevem um ambiente próprio da cultura grega, realizando uma censura implícita aos costumes e instituições romanas, sem se referir diretamente a elas. Além disso, põem em cena personagens extravagantes e situações inaceitáveis ao mundo romano (p. 64).

Perseguindo a mesma tópica, nas belas-letras do século XIV pode-se encontrar a incidência do tema do enganador enganado em algumas novelas contidas na obra $E l$ Decamerón de Giovanni Boccaccio. Como exemplo, cito o Conto IX da Jornada VIII. A história se desenrola na cidade de Palermo, envolvendo um jovem comerciante florentino chamado Niccolo de Cignano, conhecido por Salabaetto, e uma "dama":

\footnotetext{
${ }^{138}$ Martín Jiménez, Alfonso. "Burladores y engañados en la comedia europea; La comedia de los asnos, de Plauto, La mandrágora, de Maquiavelo y Las alegres casadas de Windsor, de Shakespeare". Disponível em: https://uvadoc.uva.es/bitstream/10324/2081/1/BURLADORES\%20Y\%20ENGA\%C3\%91ADOS\%20EN \%20LA\%20COMEDIA\%20EUROPEAOCROCR.pdf. Acesso em: 30 jun. 2014.

${ }^{139} \mathrm{Idem}$. Na obra La comedia de los asnos de Plauto, segundo o pesquisador, os escravos fazem o papel de enganadores, especialmente Leônidas, ao assumir "una falsa identidad para consumar la farsa". Plauto cria cenas risíveis, baseadas no fingimento, geralmente ignorado por algum dos personagens. Por sua vez, os fatos são de conhecimento do público, o que the permite rir das situações resultantes da simulação (p. $66)$.
} 
madame Iancofiore. A prostituta o seduz ${ }^{140}$ e engendra um plano para tirar do jovem comerciante "mil florines de oro". Evidentemente, o comerciante acaba enganado pela esperta Iancofiore. Aconselhado por um amigo, Salabaetto põe em prática um plano que será responsável não somente pela recuperação da importância perdida, como também por transformar a prostituta de enganadora em enganada.

Retornando à novela cervantina "El coloquio de los perros", verifica-se a presença do tema "del burlador burlado" por meio de um pequeno relato que Berganza introduz ao final da narrativa que se refere ao oficial de justiça.

Berganza narra ao amigo Cipión a curiosa história que envolve o roubo de um cavalo na cidade de Antequera e do ardil utilizado por dois ladrões, a fim de que o animal fosse vendido sem maiores problemas.

BERGANZA. Dos ladrones hurtaron en Antequera un caballo muy bueno; trujéronle a Sevilla, y para venderle sin peligro usaron de un ardid que, a mi parecer, tiene del agudo y del discreto. (CERVANTES, 2005, p. 691)

Para Berganza, ao que concerne à agudeza, essa artimanha introduz algo repentino, admirável no sentido de excelência, levando em conta aqueles que a recebem. Ao ser executado com prontidão, causa surpresa e maravilha, pois, como artifício engenhoso, demanda certo talento. Apesar de ser inesperado, o ardil, como ação astuta, também foi calculado, porque sua elaboração exige engenho ou, como diz Hansen em estudos recentes, ${ }^{141}$ se caracteriza por uma agudeza de ação, inerente aos "sentidos

\footnotetext{
${ }^{140}$ BOCCACCIO, Giovanni. El Decamerón.

Disponível em: http://www.ciudadseva.com/textos/cuentos/ita/boccaccio/08_10.htm. Acesso em: 23 jun. 2014.“- ¡Ay, dulce señor mío! No sé qué hacer ni qué decir. Acabo de recibir cartas de Mesina, y me escribe mi hermano que, aunque debiese vender y empeñar todo lo que tengo, que sin falta le mande antes de ocho días mil florines de oro y que si no le cortarán la cabeza; y yo no sé qué puedo hacer para poder tenerlos tan rápidamente; que, si tuviese al menos quince días de tiempo, encontraría el modo de proveerme de ellos de un lugar donde debo tener muchos más, o vendería algunas de nuestras posesiones; pero no pudiendo, querría estar muerta antes de que me llegase aquella mala noticia." (DECAMERÓN, Cuento IX, Jornada VIII)

${ }^{141}$ HANSEN, João A. "Agudezas seiscentistas".
} 
agudos", originários de feitos engenhosos (p. 88). Em outras palavras, a execução do ardil foi inesperada, mas sua elaboração foi calculada e, por isso, aguda.

Ao ser distinguido como um ato de astúcia pelo protagonista do "Coloquio", o ardil se constitui, como diz Maria Augusta da Costa Vieira ${ }^{142}$ em seu livro A narrativa engenhosa de Miguel de Cervantes, em uma atitude discreta, pois "produz aparências adequadas" à situação. O que a leva a afirmar que o discreto possui "ações calculadas, dissimuladas e prudentes", porque

Trata-se, em outros termos, da introdução racional de um certo teatro da vida, que encontraria no mundo o seu palco e em cada canto da cena um de seus antagonistas. [...] A introdução consciente dessa dimensão teatral da vida cotidiana seria um modo de se evitar a expressão mais direta dos desejos e de introduzir a diplomacia como uma condição para as boas relações. (VIEIRA, 2012, pp. 190-1)

É oportuno ressaltar que o caso narrado é fruto da artimanha de dois ladrões, o que se supõe serem homens pertencentes à plebe, ou seja, aos estamentos mais baixos da sociedade. Entretanto, como categoria intelectual, a discrição pode ser observada tanto em homens da corte quanto da plebe, como já se sabe, o que conduz a concluir que o ardil utilizado não somente se justifica pelo caráter engenhoso, como também recebe o atributo de discreto devido à sua meticulosidade, afinal se trata de um feito calculado. Nesses termos, ambos os personagens instituíram a representação adequada às exigências da ocasião, sem contar com a marca teatral das ações que se desenrolaram nesse instante da novela, conforme a narrativa de Berganza:

BERGANZA. Fuéronse a posar a posadas diferentes, y el uno se fue a la justicia y pidió, por una petición, que Pedro de Losada le debía

Disponível em: http://periodicos.uesb.br/index.php/floema/article/viewFile/79/86. Acesso em: 12 abr. 2012.

${ }_{142}$ VIEIRA, Maria Augusta da Costa. A narrativa engenhosa de Miguel de Cervantes. São Paulo: Edusp/Fapesp, 2012. 
cuatrocientos reales prestados, como parecía por una cédula firmada de su nombre, de la cual hacía presentación. Mandó el tiniente que el tal Losada reconociese, le sacasen prendas de la cantidad o le pusiesen a la cárcer; tocó hacer esta diligencia a mi amo y al escribano [...]; llevoles el ladrón a la posada del otro, y al punto reconoció su firma y confesó la deuda, y señaló por prenda de la ejecución el caballo, el cual visto por mi amo, le creció el ojo, y le marcó por suyo si acaso se vendiese. (CERVANTES, 2005, pp. 691-2)

Não há dúvidas de que os ladrões encenaram todo um espetáculo engendrado cuidadosamente. Um passando-se por Pedro de Losada, o outro como credor de uma dívida inexistente. A astúcia de ambos é evidente e o ardil, como diria Berganza, tem algo de agudo e discreto, seja pela representação, seja pela simulação de gestos e palavras. A apresentação da "cédula y la firma en ella", embora falsificada, supõe um conhecimento dos procedimentos jurídicos e financeiros da época referentes ao caso. $\mathrm{O}$ esperado era o interesse do oficial de justiça no cavalo. Entretanto, o inesperado estava por vir:

BERGANZA. Dio el ladrón por pasados los términos de la ley, y el caballo se puso en venta e se remató en quinientos reales en un tercero que mi amo echó de manga para que se le comprase. Valía el caballo tanto y medio más de lo que dieron por él [...]. Cobró el ladrón la deuda que no le debían, y el otro la carta de pago que no había menester, y mi amo se quedó con el caballo, que para él fue peor que el Seyano lo fue para sus dueños. (CERVANTES, 2005, p. 692).

A história do cavalo Seyano ${ }^{143}$, conforme pesquisa, foi extraída da narração feita por Fray Antonio de Guevara em uma carta que enviou a D. Juan de Palemos, na qual

\footnotetext{
${ }^{143}$ Para Guevara, a história do cavalo foi narrada por autores como Gayo Basiano, Julio Modesto e Aulio Gelio, no terceiro livro que fez: Noches de Atenas. "Assim, o grande Hércules [...] trouxe para a Grécia uma raça de cavalos de cores muito bonitas, corpos grandes, mansos e bem dispostos para as batalhas." GUEVARA, Antonio de. "Epístola XXI, Letra para D. Juan de Palemos, en la cual se declara quién fue el caballo Seyano y el oro tolosano". In: OCHOA, Don Eugenio de. Biblioteca de Autores Españoles desde la formación del linguaje hasta nuestros días - Epistolario Español, Colección de Cartas de Españoles Ilustres Antiguos y Modernos. Madrid: Imprenta de la publicidad, 1850. pp. 107-8.
} 
relata quem foi "el caballo Seyano". O bispo de Mondoñedo narra que o animal nasceu na província de Argos, Grécia, e devido ao seu porte e beleza era muito cobiçado, embora todos os seus cinco donos tiveram mortes trágicas, a saber: os cônsules Gneo Seyano, Dolobela e Cayo Casion, o famoso romano Marco Antônio e o cavaleiro Nigidio.

Nesse contexto, Berganza afirma que o cavalo adquirido pelo amo era pior que o de Argos, isto é, como uma "ave de mau agouro", o animal só conseguiu trazer aos seus cavaleiros um destino terrível; em se tratando do oficial de justiça, como seria o desfecho dessa história? Para os ladrões que o roubaram de Antequera o cavalo, ao contrário do lendário Seyano, não lhes proporcionou nenhum azar, até fugiram com o produto do furto sem sofrerem danos. Entretanto, para o oficial de justiça a situação foi bem diferente. A princípio, o amo de Berganza era só pompa e arrogância, desfilando sobre o cavalo para que todos o vissem.

BERGANZA. [...] pareció sobre él en la plaza de San Francisco, más hueco y pomposo que aldeano vestido de fiesta. Diéronle mil parabienes de la buena compra [...] y él, volteando y revolviendo el caballo, representaba su tragedia en el teatro de la referida plaza. (CERVANTES, 2005, p. 693)

Dessa maneira, retomando o tema mencionado anteriormente nesse episódio da novela, torna-se evidente a necessidade do oficial de justiça da aprovação pública, mesmo que a representação que fazia de si era falsa. Nesse sentido, os acontecimentos relatados por Berganza manifestam as ações desmedidas de seu amo, ora por acreditar em ter feito um bom negócio, ora com respeito ao prestígio que recebia por estar em tão valiosa montaria. Ao contrário dos ladrões mencionados, o oficial não se caracterizava por ter ações discretas, não possuía discernimento, era conduzido pelas aparências, ou melhor, se deixava enganar por essas aparências. 
Entretanto, o oficial de justiça não esperava que o verdadeiro dono do cavalo aparecesse na cidade, reconhecendo-o prontamente:

BERGANZA. Y estando en sus caracoles y rodeos, llegaron dos hombres de buen talle y de mejor linaje, y el uno dijo: "¡Vive Dios, que éste es Piedehierro, mi caballo, que ha pocos días que me hurtaron de Antequera!”. Todos los que venían con él, que eran cuatro criados, dijeron que así era la verdad, que aquél era Piedehierro, el caballo que le habían hurtado. (CERVANTES, 2005, p. 693)

O que se pode perceber nessa passagem da novela é a incidência da tópica "del burlador burlado", embora o amo de Berganza esteja vinculado à representação cômica do ridículo que incita o riso, ao contrário do herói grego, por exemplo, associado a uma figura positiva da épica. Os ladrões deixaram à mostra os embustes do amo de Berganza, agora descobertos por intermédio do conto ou do "caso" narrado pelo protagonista. Nesse aspecto, o engano evidencia-se diante de todos; e o que antes não passava de uma farsa bem representada pelo oficial, agora o mesmo se vê obrigado a representar, também, a própria tragédia "en el teatro de la referida plaza", como diria Berganza.

Como desfecho da história, o cavalo roubado retornou ao seu verdadeiro dono. Quem comprou e não levou foi o oficial de justiça, que, além de sofrer a perda do dinheiro empregado em um cavalo roubado, acabou desacreditado diante de todos os conhecedores do caso - como enganador mereceu ser enganado.

BERGANZA. Súpose la burla y la industria de los ladrones, que por manos e intervención de la misma justicia vendieron lo que habían hurtado, y casi todos se holgaron de que la codicia de mi amo le hubiese rompido el saco. (CERVANTES, 2005, p. 693)

No entanto, o azar do oficial de justiça não terminava com esse prejuízo financeiro e moral, pois ele ainda passaria por mais uma desventura. 
BERGANZA. [...] aquella noche, saliendo a rondar el mismo asistente, por haberle dado noticia que hacia los barrios de San Julián andaban ladrones, [...] vieron pasar un hombre corriendo, y dijo a este punto el asistente, asiéndome por el collar y zuzándome: “¡Al ladrón, Gavilán! ¡Ea, Gavilán, hijo, al ladrón, al ladrón!”.

Como estivesse cansado das maldades de seu amo, Berganza, cumprindo as ordens do assistente, avançou sobre o oficial de justiça, jogando-o ao solo.

BERGANZA. [...] por cumplir lo que el señor asistente me mandaba sin discrepar en nada, arremetí con mi amo, y sin que pudiese valerse, di con él en el suelo; y si no me le quitaran, yo hiciera a más de a cuatro vengados; quitáronme con mucha pesadumbre de entrambos. Quisieran los corchetes castigarme, y aun matarme a palos, y lo hicieran si el asistente nos les dijera: "No le toque nadie, que el perro hizo lo que yo le mandé”. (CERVANTES, 2005, pp. 693-4)

O ataque de Berganza ao oficial mediante a ordem do assistente retrata não somente seu desapontamento diante das faltas de seu amo, como também expõe moralmente os crimes do antagonista. Com respeito ao assistente, este percebe a malícia que em sua opinião se constitui em censura, perdoa a ação violenta do animal e ainda ordena que o mesmo não seja castigado, pois apenas seguia seu comando: “¡Al ladrón, Gavilán! ¡Ea, Gavilán, hijo, al ladrón, al ladrón!”. Tanto a ação do mastim quanto a ordem do assistente no sentido de não o castigarem desqualificam o oficial de justiça; um pela interpretação às avessas, embora intencional, do comando dado, o outro por perdoar o ataque do cão, justificando-o. Ambos expõem claramente os crimes do personagem ao "retratá-lo como tipo e destratá-lo como infame". (HANSEN, 2004, p.

Como mencionado anteriormente, o episódio se traduz como uma sátira moral, não como correção das falhas, mas como um tipo de representação, ao modo de Cervantes, que surge apenas como exposição de ações observadas no âmbito do 
ridículo. Conforme o pesquisador João A. Hansen, ${ }^{144} \mathrm{em}$ seu livro A sátira e o engenho, ao tratar sobre os preceitos que regulam o uso da sátira, afirma que

Dois princípios complementares modulam a visada: a exclusão dos corpos que o olho constitui, remetidos para os modos negativos da ausência de Bem - falha, falta, erro, pecado - e a sua inclusão, que os traduz poeticamente como ridículos, moralmente como viciosos, politicamente como culpados na luz da sua verdade. (HANSEN, 2004, p. 194)

No que se refere ao oficial de justiça, ao observar o caso narrado por Berganza, seu propósito se pauta na amplificação de vícios seja por meio do ataque que faz ao antagonista, seja pela ação indulgente do assistente para com o cão, as vilezas do personagem acabam sendo expostas ao olhar alheio. Sua aparente valentia, agora se transforma em deformação, em falta, em pecado e o oficial como enganador, acaba na posição de enganado. Assim, o antagonista representa a desonestidade, a aplicação torpe da justiça, que não remete ao escândalo ou ao escárnio, mas se converte em ironia, em um benevolente riso cervantino.

Dessa maneira se constitui a sátira em Cervantes, não conflitiva ou mordaz, sem feridas ou infâmias, somente censura a monstruosidade, servindo-se do gracejo, em um jogo de ações e palavras. Como diz o próprio autor ao referir-se às novelas exemplares, pode-se supor que sua sátira se constitua na narrativa [...] sin daño del alma ni del cuerpo, porque los ejercicios honestos y agradables antes aprovechan que dañan”.

Retomando o "Coloquio", como sempre, após tantos sucessos e desventuras, Berganza encerra sua convivência com o oficial de justiça, pois “ [...] sin despedirse de nadie, por un agujero de la muralla salí al campo, y antes que amaneciese me puse en

\footnotetext{
144 HANSEN, João A. A sátira e o engenho. 2 ed. São Paulo/Campinas: Ateliê Editorial/ Editora da Unicamp, 2004.
} 
Mairena, que es un lugar que está cuatro leguas de Sevilla." (CERVANTES, 2005, p. 694). 


\section{Considerações finais}

Após esse longo percurso interpretativo sobre o corpus selecionado da novela exemplar "El coloquio de los perros" de Miguel de Cervantes, tornou-se possível levantar algumas considerações relacionadas com as inferências propostas no decorrer da análise com respeito aos preceitos do gênero cômico, salientando a maneira como se constituem em cada episódio estudado da obra.

Conforme o proposto para o primeiro capítulo, a análise se ateve no que concerne aos princípios de verossimilhança e admiração abordados pelos protagonistas caninos Berganza e Cipión ao se depararem com o dom da fala. Após introduzirem algumas hipóteses que poderiam justificar essa dádiva repentina, os protagonistas introduzem nessa passagem uma preocupação latente que se estenderá até o final da novela, ou seja, a preocupação com respeito à credibilidade da própria narrativa, levando em conta que a mesma provém de um diálogo entre dois cães.

Assim, por meio desse elemento fantástico, a admiração dos personagens será responsável pela possível conclusão desse mistério. Após algumas suposições levantadas pelos protagonistas no que concerne a esse surpreendente dom, Cipión encerra a disputa ao atribuir essa dádiva aos céus e "[...] lo que el cielo tiene ordenado, que suceda, no hay diligencia ni sabiduría humana que lo pueda prevenir" (p. 651).

Com respeito à recepção da novela, no instante em que o leitor se vê instigado a desvendar esse inquietante acontecimento, diante da exposição dos feitos relatados pelo protagonista, esse destinatário se vê impelido a aceitá-lo sem maiores questionamentos.

Nesses termos, a comicidade nesse trecho da narrativa está nas diversas hipóteses levantadas pelos cães ao procurarem uma justificativa plausível para o 
injustificável dom da fala. E será por intermédio desse dom que os cães decidem narrar a história de suas vidas, a começar pelas reminiscências de Berganza, partindo de seu nascimento no matadouro de Sevilha. O protagonista irá retratar seu primeiro amo, o açougueiro Nicolás el Romo, bem como os frequentadores do lugar.

Esses personagens serão responsáveis pelas ações reprováveis percebidas no episódio, cuja descrição se dará por meio do uso de elementos relacionados à argumentação, tais como: silogismos, entimemas; vinculados à ornamentação do discurso como é o caso das metáforas e alegorias. Em outras palavras, Berganza apresentará um discurso que tende a um estilo agudo, com a finalidade de descrever não somente o espaço do matadouro, mas de censurar as vilezas dos personagens relacionados.

Entretanto, essas reminiscências sofrem inúmeras interrupções de Cipión, que como interlocutor sempre apresentará observações filosóficas e exemplares, com certo tom moral, a fim de que a narrativa não se converta em um discurso maledicente, repleto de intermináveis digressões.

Diante dos pecados dessa "buena gente", Berganza foge do Matadouro e dirigese para o campo, onde se converte em "perro pastor", acreditando, enfim, ter encontrado seu lugar no mundo, sua verdadeira missão: “defender de los poderosos y soberbios los humildes y los que poco pueden" (p. 657). Tem-se nesse instante do "Coloquio" o enaltecimento do campo, da vida pastoril, cuja tarefa consiste em despertar no homem a virtude perdida, diante das tentações e deleites da cidade - um tema recorrente em algumas obras do período, como demonstrado no transcorrer do trabalho dissertativo.

Mas, à medida que Berganza estabelece um comparativo dos pastores seus amos com os contidos nas novelas pastoris, lidas pela esposa do dono do rebanho, as discrepâncias entre os personagens começam a emergir, fazendo com que o protagonista 
apresente certas dúvidas com respeito ao gênero, considerando os modelos representados por seus amos pastores.

Assim, no que concerne a esse comparativo, os questionamentos do protagonista se encaminham para os critérios referentes ao conceito de decoro, tendo em vista as incongruências observadas pelo cão entre o estilo rude de seus amos pastores diante da erudição apresentada pelos personagens pertencentes às novelas pastoris. Ao mesmo tempo, essas discrepâncias conduzem o protagonista ao desvelamento de algumas práticas criminosas de seus amos; uma delas consiste no roubo das ovelhas do rebanho, fazendo com que lancem a culpa em uma suposta ação de lobos.

Diante de tais deformações morais, Berganza institui uma censura com respeito às ações dos pastores, introduzindo um discurso cômico ora por meio de um riso benevolente e inofensivo, ora mediante um riso mordaz e nocivo, sem fins moralizantes. No entanto, esse discurso sempre será repreendido por Cipión, cuja proposta está em direcionar a narrativa de Berganza a fim de "que el relato no se deslice por senderos múltiples que al fin y al cabo podrían conducir a las vías del vicio"145 (VIEIRA, 2011, p. 109).

Nesse sentido, vê-se que mais uma vez, no "Coloquio", as deformidades morais são amplificadas pelo olhar atento de Berganza que, diante de um mundo às avessas, em "que la defensa ofende, las sentinelas duermen, que la confianza roba y él que os guarda os mata" (p. 665), determina deixar o campo e retornar à cidade de Sevilha.

O retorno de Berganza à cidade é marcado por sua permanência na casa de um rico comerciante. Questões envolvendo códigos de conduta próprios da sociedade de corte seiscentista e a lealdade entre senhores e criados são os principais temas a ser analisados nesse episódio. Apesar desses conceitos serem abordados por muitos

${ }^{145}$ VIEIRA, Maria Augusta da Costa. La discreción de Cipión. Actas del I Congreso de Hispanistas Siglo de Oro e Hispanismo General, New Delhi - Índia. Ed. de Vibha Maurya e Mariela Insúa. Pamplona: 2011. 
estudiosos daquele período, Cervantes os emula mediante citações cômicas, ironias, provavelmente em prol de uma narrativa que tem como proposta o entretenimento.

Por outro lado, outros assuntos são referendados nessa passagem da novela, como por exemplo: o uso indevido do latim, a fim de descrever a inadequação tanto de ações quanto de palavras nas práticas sociais.

Enfim, tem-se o último episódio selecionado, o qual consiste na descrição de uma série de peripécias narradas por Berganza quando esteve a serviço de um oficial de justiça corrupto. Como as próprias qualidades desse personagem não deixam quaisquer dúvidas, suas práticas viciosas e outras questões morais serão o foco dessa passagem da novela. Nessa configuração, Berganza se depara com um amo com características picarescas, seja pelas ações, seja pelas parcerias que sustenta com os membros da "hampa sevillana", a saber: rufiões, prostitutas, ladrões, gente da pior espécie que o ajuda em suas artimanhas em troca de favores, sem contar com a colaboração que recebia do escrivão juntamente com a dos beleguins. Nesse momento, as fraquezas humanas são observadas pelo olhar atento e muitas vezes ingênuo de Berganza, cujas inúmeras observações murmurantes, sempre serão pontualmente advertidas pelo interlocutor Cipión. Apesar das ações criminosas do oficial de justiça, sua história é repleta de situações cômicas, sendo a utilização do elemento cênico responsável pela transformação desse episódio em um possível entremez. Como pequena representação cênica introduzida nos intervalos das comédias nos séculos XVI e XVII, o entremez se destaca por seu estilo cômico, que institui ora a mordacidade, ora a pantomima que incita ao riso.

Essas características burlescas são instituídas no episódio por intermédio das personagens de baixa condição, as quais fazem uso de uma linguagem própria ao 
estamento a que pertencem, como é o caso da utilização de termos em germanía - uma linguagem que participa dessa pequena encenação até o seu final.

Nesses termos, ao se observar os personagens do matadouro, do campo, da casa do rico comerciante e do episódio que envolve o oficial de justiça, pode-se supor que todos representam uma alegoria às avessas do estado absolutista, até mesmo porque os personagens elencados retratam, de maneira contrária à ordem natural, uma desestabilização hierárquica, uma desarmonia social, opostas a um fim que seria o bem comum.

Assim, a descrição desse cotidiano social feita por Berganza tem como alvo não a censura a indivíduos pertencentes aos estamentos mais baixos, mas às práticas viciosas que os individualiza, no instante em que as ações retratam suas deformações morais.

Dessa maneira, por meio da narrativa de Berganza e das observações bem marcadas de Cipión, a novela exemplar "El coloquio de los perros" institui um diálogo narrativo, com um tom muitas vezes moral, seja por aproximar-se das fábulas esópicas, do folclore popular, seja pela possível relação que estabelece com a filosofia cínica, o fato é que a obra surpreende por seu caráter notável, pois apresenta um colóquio entre dois cães com conhecimento filosófico, cuja missão se pauta em observar atentamente as condutas da sociedade ao seu redor.

Além disso, a novela retoma algumas tópicas utilizadas por autores da época, que são introduzidas mediante as reminiscências do protagonista. Em outras palavras, Cervantes institui por intermédio dos cães Berganza e Cipión um diálogo que ora apresenta características burlescas, ora doutrinais, possivelmente com o propósito não só de resgatar valores cristãos há muito esquecidos, mas em prol do entretenimento, do riso. 
Como diria Peralta no final da leitura do "Coloquio":

- Aunque este coloquio sea fingido y nunca haya pasado, paréceme que está bien compuesto [...]. Yo alcanzo el artificio del coloquio y la invención, y basta. Vámonos al Espolón a recrear los ojos del cuerpo, pues ya he recreado los del entendimiento. (CERVANTES, 2005, pp. 736-7). 


\section{Referências bibliográficas}

\section{Do autor:}

CERVANTES, Miguel de. "El coloquio de los perros". In: Novelas ejemplares. Barcelona: Crítica, 2005.

. "El coloquio de los perros". In: Novelas ejemplares. Madrid: Clásicos Universales, 2004. Los seis libros de la Galatea. Disponível em:

http://www.cervantesvirtual.com/obra-visor/los-seis-libros-de-la-galatea--

0/html/

Don Quijote de la Mancha. Parte I. Brasil: RAE, 2004.

. Segunda parte del ingenioso cavallero Don Quijote de la Mancha. Brasil: RAE, 2004.

. Retablo de las maravillas, entremés. Brasília: Thesaurus Editora, 2004. Entremeses. Madrid: Cátedra, 1989.

Textos críticos sobre a obra:

ALCÁZAR, Jorge. La filiación genérica del "Coloquio de los perros". Disponível em: http://www.revistas.unam.mx/index.php/rap/article/view/23136. Acesso em: 20 fev. 2013.

CARRASCO, Félix. "El coloquio de los perros": veridicción y modelo narrativo. Disponível em: http://cvc.cervantes.es/literatura/criticon/pdf/035/035_121.pdf. Acesso em: 10 maio 2012. 
CLOSE, Anthony. Cervantes y la mentalidad cómica de su tiempo. Madrid: Biblioteca de Estudios Cervantinos, 2007.

ILLADES, Gustavo. Sátira, prédica y murmuración: genealogía de una contienda por la voz en el Quijote de 1605. Disponível em: http://www.hnet.org/ cervantes/csa/artics07/illadess07.pdf. Acesso em: fev. 2010.

JOLY, Monique. Rebuzne el pícaro: comentarios sobre el uso cervantino de una fábula de Esopo. Disponível em:

http://cvc.cervantes.es/literatura/aih/pdf/08/aih_08_2_007.pdf. Acesso em: 05 mar. 2012.

LOZANO MAÑERO, David. Diálogo y picaresca en "El coloquio de los perros".

Disponível em:

http://www.persee.fr/web/revues/home/prescript/article/hispa_00074640_2004_num_106_2_5200. Acesso em: 13 fev. 2014.

MIÑANA, Rogelio. Metaficción y monstruosidad en "El coloquio de los perros" de Cervantes. Disponível em: http://ejournals.library.vanderbilt.edu/index.php/lusohispanic/article/view/3166/ 1341

OLIVER, Antonio. La filosofía cínica y el "Coloquio de los perros". Anales cervantinos, mar. 1953.

REY-HAZAS, Antonio. "Género y estrutura de "El coloquio de los perros", o como se hace una novela". In: Lenguaje, ideología y organización textual en las Novelas ejemplares. Actas del Coloquio celebrado en la Facultad de Filología de la Universidad Complutense en mayo de 1982. Madrid: Universidad Complutense; Toulouse: Université de Toulouse-Le Mirail, 1983. 
RILEY, Edward C. La profecía de la bruja en "El coloquio de los perros". In: Actas del Primer Coloquio Internacional de la Asociación Cervantista. Alcalá de Henares: 1988. Revista Anthropos.

RÍOS ROJAS, Antonio. Comentario al "Coloquio de los perros” de Cervantes.

Disponível em:

http://pendientedemigracion.ucm.es/info/especulo/numero32/coperros.html.

Acesso em: 04 jul. 2012.

RODRÍGUEZ-LUIS, Julio. Autorrepresentación en Cervantes y el sentido del "Coloquio de los perros".

Disponível em: http://www.cervantesvirtual.com/obra-visor/cervantes-bulletinof-the-cervantes-society-of-america--48/html/02790320-82b2-11df-acc7-

002185ce6064_17.html. Acesso em: 21 mar. 2012.

RODRIGUEZ MANZILLA, Fernando. "El coloquio de los perros": de la fábula a la novela. In: ESPINOSA, Antonio César; RUIZ MARTÍNEZ, José Manuel (Orgs.). "En teoría hablamos de literatura". In: Actas del III Congreso Internacional de Aleph, Granada, 3-7 abr. 2006.

SOBEJANO, Gonzalo. "El coloquio de los perros" en la picaresca y otros apuntes.

Disponível em:

http://home.uchicago.edu/ jorgea/untitled\%20folder/Coloquio\%20picaresca.pdf. Acesso em: 30 jul. 2012.

VIEIRA, Maria Augusta da Costa. La discreción de Cipión. Actas del I Congreso de Hispanistas Siglo de Oro e Hispanismo General, New Delhi - Índia. Ed. de Vibha Maurya e Mariela Insúa. Pamplona: 2011. 


\section{Geral:}

ACCETTO, Torquato. Da dissimulação honesta. São Paulo: Martins Fontes, 2001.

AMADOR DE LOS RÍOS, Jose. Historia crítica de la literatura española.

Disponível em:

http://books.google.com.br/books?id=AjkLAAAAQAAJ\&pg=PR22\&lpg=PR22 $\& \mathrm{dq}=$ Com.

ALIGHIERI, Dante. A divina comédia. Disponível em:

http://www.stelle.com.br/pt/inferno/inferno.html. Acesso em: 2 dez. 2013.

ANTONIO MARAVALL, José. La literatura picaresca desde la historia social (Siglos XVI y XVII). Madrid: Taurus, 1986.

APULEYO. El asno de oro. Madrid: Alianza, 1988.

AQUINO, Santo Tomás de. Suma teológica. Parte Ia, Cuestión 116. Disponível em: http://hjg.com.ar/sumat/a/c116.html. Acesso em 2 jul. 2012.

ARELLANO, Ignacio. "Las máscaras de Demócrito: em torno de la risa em el Siglo de Oro”. In: AZAUSTRE GALIANA, Antonio; ARELLANO, Ignacio; LÓPEZ, Victoriano Roncero (Orgs.), Demócrito áureo: los códigos de la risa en el Siglo de Oro. Sevilla: Editorial Renacimiento, 2006.

. Visiones y símbolos emblemáticos en la poesía de Cervantes. Disponível

em: analescervantinos.revistas.csic.es/index.php/.../164. Acesso em: 10 fev. 2014.

ARMISEN, Antonio. “Admiración y maravillas en 'El criticón’ (Más unas notas cervantinas)". Disponível em:

ifc.dpz.es/recursos/publicaciones/28/59/12armisen.pdf.

ASENSIO, Eugenio. Itinerário del entremés desde Lope de Rueda a Quiñone de Benavente. Madrid: Ed. Gredos, 1971. 
. Entremeses. In: AVALLE-ARCE, Juan Bautista; RILEY, E. C. Suma

cervantina. London: Tamesis, 1973.

ARISTÓTELES. Metafísica. Madrid: Gredos, 2006.

Ética a Nicômaco. Madrid: Instituto de Estudios Políticos, 1970.

. Poética. Madrid: Alianza, 2009.

Retórica. Madrid: Alianza, 2007.

AVALLE-ARCE, Juan Bautista. La novela pastoril española. Madrid: Istmo,1974.

AVALLE-ARCE, Juan Bautista; RILEY, E. C. Suma cervantina. London: Tamesis, 1973.

Bíblia Sagrada On-line. Disponível em: http://www.bibliaon.com. Acesso em: 5 mar. 2012.

BOECIO, La consolación de la filosofía. Madrid: Akal, 1997, p. 29. Disponível em: http://books.google.com.br/books?id=NT4VEaZA5Z0C\&printsec=frontcover\&hl=ptBR\&source $=$ gbs_ge_summary_r\&cad $=0 \# \mathrm{v}=$ onepage $\& \mathrm{q} \& \mathrm{f}=$ false

BRANDÃO, Jacynto Lins. A poética do hipocentauro. Belo Horizonte: Humanitas, 2001. BURRIEZA SÁNCHEZ, Javier. "La Compañía de Jesús y la defensa de la monarquía hispánica". Disponível em: http://digital.csic.es/bitstream/10261/15836/3/54. Acesso em: 15 jul. 2011. . Misión de la Compañía de Jesús en el siglo de la Reforma. In: EGIDO, Teófanes (Org.). Los jesuitas en España y en el mundo hispánico. Madrid: Marcial Pons, Ediciones de Historia S.A., 2004.

CARRATORE, Enzo del. Introdução do estudo das sátiras de Horácio. Disponível em: http://seer.fclar.unesp. br/alfa/article/view/3193.pdf. Acesso em: 4 mar. 2013. 
CARVALHO, Maria do Socorro Fernandes de. Poesia da agudeza em Portugal: estudo retórico da poesia lírica e satírica escrita em Portugal no século XVII. São Paulo: Edusp e Humanitas, 2007.

CARRANZA, Pablo. Cipión, Berganza y la tradición esópica. Disponível em: http:// cervantesvirtual.com/obra-visor/cervantesbulletin-of-the-cervantes-society.html. Acesso em: 31 out. 2013.

CASTIGLIONE, Baldassare. O cortesão. São Paulo: Martins Fontes, 1997.

CICERÓN, Marco Tulio. Sobre los deberes. Trad. de José Guillén Cabañero. Madrid: Alianza, 2008.

. Do sumo bem e do sumo mal. São Paulo: Martins Fontes, 2005.

. Diálogo del orador - Libro II”. In: Obras escogidas. Buenos Aires: El Ateneo, 1951.

."El sueño de Escipión en Sobre la República”. Barcelona: Biblioteca Clásica Gredos/ Ed. Planeta de Agostini, 2010.

Disponível em: http://xmejuto.blogspot.com/2010/01/el-sueno-de-escipionmarco-tulio.html. Acesso em: 15 out. 2013.

CLOSE, Anthony. Cervantes y la mentalidad cómica de su tiempo. Madrid: Biblioteca de Estudios Cervantinos, 2007. . Algunas reflexiones sobre la sátira en Cervantes. In: Nueva Revista de Filología Hispánica, Centro de Estudios Linguiísticos y Literarios, Tomo XXXVIII. México: 1990.

. "La aportación de tres hispanistas franceses al estudio del folklore en el Quijote”. In: Tus obras los rincones de la tierra descubren. Actas del VI Congreso Internacional de la Asociación de Cervantistas. Disponível em: 
http://cvc.cervantes.es/literatura/cervantistas/congresos/cg_VI/cg_VI_15.pdf. Acesso em: 10 jun. 2014.

COVARRUBIAS y OROZCO, Sebastián. Tesoro de la lengua castellana o española. Disponível em: http://books.google.com.br/books?id=K10MJdL7pGIC\&printsec=frontcover\&d q=tesoro+de+la+lengua+castellana\&hl. Acesso em: 8 mar. 2012.

CRIADO, Manuel de Val. La picaresca: Orígenes, textos y estructuras. Madrid: Fundación Universitaria Española, 1979.

DANTISCO, Lucas Gracian. Galateo español. Madrid: Atlas, 1943.

DIDIER, Hugues, Censura e idiomas en la España del Siglo de Oro: Juan Eusebio Nieremberg. Disponível em: http://cvc.cervantes.es/literatura/aiso/pdf/04/aiso_4_1_049.pdf. Acesso em: 17 dez. 2013.

DON CARLOS IV. Novísima recopilación de las Leyes de España. Tomo III. Libros VI y VII. Disponível em: Universidad de Sevilla. Biblioteca de la Facultad de Derecho. Disponível em: http://fama2.us.es/fde/ocr/2006/novisimaRecopilacionT1.pdf. Acesso em: 2 dez. 2013.

DOMÍNGUEZ GARCIA, José Manuel. La cátedra de latinidad de Betanzos (16141853). Disponível em: http://anuariobrigantino.betanzos.net/Ab1995PDF/1995\%20061_076.pdf. Acesso em: 6 jan. 2014.

ELIAS, Norbert. La sociedad cortesana. México: Fondo de Cultura Económica, 1996. 
ESOPO, Fábulas. Disponível em: http://www.guiainfantil.com/articulos/ocio/cuentosinfantiles/el-aguila-el-cuervo-y-el-pastor-fabula-de-esopo-para-ninos/. Acesso em: 4 nov. 2013. . Fábulas completas. São Paulo: Cosac \& Naify, 2013. . Fábulas. Intr. de Carlos Garcia Gual. Barcelona: Gredos, 2008.

FAJARDO, Saavedra. Idea de un príncipe político-cristiano. Madrid: Espasa-Calpe, 1969.

FLACO, Quinto Horácio. El arte poética ó epistola a los pisones. Disponível em: http://www.traduccionliteraria.org/biblib/H/H101.htm. Acesso em: 2 abr. 2012.

GARCÍA-GUAL, Carlos; LAÉRCIO, Diógenes. La secta del perro: Vidas de los filósofos cínicos. Madrid: Alianza, 2011.

GARRIDO DOMINGUÉZ, Antonio. Aspectos de la novela en Cervantes. Madrid: Ediciones del Centro de Estudios Cervantinos, 2007. Disponível em: http://books.google.com.br/books?id=wmxmSoRM2mcC\&printsec=frontcover $\& \mathrm{hl}=\mathrm{pt}-\mathrm{BR} \&$ source=gbs_ge_summary_r\&cad=0\#v=onepage \&q\&f=false.

GIL, Luis. La comicidad en Aristófanes.

Disponível em: http://revistas.ucm.es/index.php/CFCG/article/view/CFCG9393110023A pdf. Acesso em: 12 ago. 2011.

GOFF, Jacques Le. O maravilhoso e o quotidiano no Ocidente medieval. Lisboa: Edições 70, 1983.

GONZÁLEZ Ramires, David. El origen de la novela corta del Siglo de Oro: Los novellieri en España. 
Disponível em:

http://arbor.revistas.csic.es/index.php/arbor/article/viewFile/1401/1410. Acesso em: 19 set. 2013.

GRAF, Fritz. Cícero, Plauto e o riso romano. In: BREMMER, Jan; ROODENBURG, Herman (Orgs.). Uma história cultural do humor. Rio de Janeiro: Record, 1997.

GRACIÁN, Baltasar. El discreto y Oráculo manual y Arte de prudencia. Barcelona: Debolsillo, 2004. Agudeza y Arte de ingenio. Madrid: Castalia, 1988. Tomos I e II.

GUEVARA, Antonio de. Menosprecio de corte y alabanza de aldea. Argentina: Espasa-Calpe, 1947.

. GUEVARA, Antonio de. Epístola XXI. In: OCHOA, Don Eugenio de. Biblioteca de autores españoles desde la formación del linguaje hasta nuestros días. Epistolario Español, Colección de cartas de españoles ilustres antiguos y modernos. Madrid: Imprenta de la publicidad, 1850. Disponível em: http://books.google.com.br. Acesso em: 18 jun. 2014.

HANSEN, João Adolfo. Alegoria, construção e interpretação da metáfora. Campinas: Editora da Unicamp, 2006. A sátira e o engenho. 2 ed. São Paulo/Campinas: Ateliê Editorial/ Editora da Unicamp, 2004. Agudezas seiscentistas.

Disponível em: http://periodicos.uesb.br/index.php/floema/article/viewFile/79/86. . As sociedades do Antigo Regime, 28 set. 2011, nota de aula. . Barroco, neobarroco e outras ruínas. 
Disponível em: http://www.destiempos.com/n14/hansen2.pdf.

“Educando príncipes no espelho". In: FREITAS, Marcos Cezar de;

KUHLMANN Jr., Moysés (Orgs.). Os intelectuais na história da infância. São Paulo, Cortez, 2002.

. La doctrina conceptista de lo cómico en el "Trattato De'Ridicoli" de Emanuele Tessauro.

Disponível em: http://bidi.unam.mx/libroe_2007/01042713/A16.pdf. Acesso em: 23 out. 2012.

. O discreto. In: NOVAES, Adauto (Org.). Libertinos e libertários. São Paulo:

Cia. das Letras, 1996.

. Razão de Estado. In: NOVAES, Adauto (Org.). A crise da razão. São Paulo:

Cia. das Letras, 2006.

. Retórica da agudeza. Disponível em:

http://pt.scribd.com/doc/59088666/Retorica-da-Agudeza-Hansen. Acesso em: 20 out. 2011.

. "Ut Pictura Poesis" e verossimilhança na doutrina do conceito no século XVII

colonial. Disponível em:

http://www.jstor.org/discover/10.2307/4530901?uid=3737664\&uid=2\&uid=4\&s

$\mathrm{id}=21102548790087$. Acesso em: 9 maio 2010.

. “Práticas letradas seiscentistas". Disponível em: http://revistas.usp.

br/discurso/article/view/37998. Acesso em: 12 abr. 2012.

HERMÓGENES. Sobre las formas de estilo. Madrid: Gredos, 1993.

ILLADES, Gustavo. Retábulo de fantasmas cervantinos. Disponível em: http://www.usp. br/revistausp/67/19-illades.pdf. 
IFE, Barry W. Lectura y ficción en el siglo de oro las razones de la picaresca. Barcelona: Crítica, 1992.

JUVENAL; PÉRSIO. Sátiras. Madrid: Gredos, 2008.

LAÉRCIO, Diógenes. Vidas de los filósofos ilustres. Madrid: Alianza, 2007.

LEÓN, Fray Luis de. De los nombres de Cristo. 2 ed. Argentina: Colleción Austral, 1945.

LEXICON, Helder Dicionário de Símbolos, São Paulo: Cultrix, 1998.

LÓPEZ-GRIGERA, Maria Luisa. La retórica en la España del Siglo de Oro. Salamanca: Universidade de Salamanca, 1994.

LULIO, Antonio. Sobre el decoro de la poética. Madrid: Clásicas, 1994.

MAESTRO, Jesús G. Cervantes y el entremés, poética de una comicidad crítica.

Disponível em:

http://cvc.cervantes.es/literatura/cervantistas/coloquios/cl_XII/cl_XII_37.pdf. Acesso em: 3 fev. 2014.

MARTÍN-CAMACHO, Javier. La risa y el humor en la antigüedad. Disponível em: http://www.fundacionforo.com/pdfs/archivo14.pdf. Acesso em: 10 ago. 2011.

MARTÍN JIMÉNEZ, Alfonso. "Burladores y engañados en la comedia europea; $L a$ comedia de los asnos, de Plauto, La mandrágora, de Maquiavelo y Las alegres casadas de Windsor, de Shakespeare".

Disponível em:

https://uvadoc.uva.es/bitstream/10324/2081/1/BURLADORES\%20Y\%20ENGA \%C3\%91ADOS\%20EN\%20LA\%20COMEDIA\%20EUROPEAOCROCR.pdf. Acesso em: 30 jun. 2014. 
MASSIMI, Marina. A teoria dos temperamentos na literatura jesuítica, nos séculos XVI e XVII. Disponível em: http://www.triplov.com/atalaia/massimi.html. Acesso em: 6 fev. 2012.

MANSUR, Juan Carlos. Belleza y formación en el pensamiento de Platón. Disponível em: http://www.ucs.br/etc/revistas/index.php/conjectura/article/viewFile/889/612. Acesso em: 19 mar. 2012.

MÁRQUEZ SÁNCHEZ, Carles. Fortuna velut luna: Iconografía de la Rueda de la Fortuna en la Edad Media y el Renacimiento. Disponível em: http://www.ehumanista.ucsb.edu/volumes/volume_17/pdfs/articles/9\%20ehuma nista17.c.sanchez.pdf. Acesso em: 10 fev. 2014.

MIÑANA, Rogelio. La verosimilitud en el Siglo de Oro: Cervantes y la novela corta. Newark, Delaware: Juan de la Cuesta, 2002.

MUHANA, Adma. A epopéia em prosa seiscentista. São Paulo: Ed. da Unesp, 1997.

NOGALES-RINCÓN, David. Los espejos de príncipes en Castilla (siglos XIII-XV): Un modelo literario de la realeza bajomedieval. Disponível em: http://revistas.um.es/medievalismo/article/view/50931. Acesso em: 28 jan.2013. Animalización, sátira y propaganda real: la metáfora y la alegoría animal como instrumento político en la Castilla Bajomedieval (Siglo XIV-XV). In: Revista Signum, 2010, v. 11, n. 1 .

Disponível em: http://www.abrem.org.br/revistasignum/index.php/revistasignumn11/article/vie w/12/11pdf. Acesso em: 25 maio 2013.

NOLTING-HAUFF, Ilse. Visión, sátira y agudeza en los sueños de Quevedo. Madrid: Ed. Gredos, 1974. 
OSORIO, Jorge A. Erasmo, a cortesia e a piedade. Disponível em: http://ler.letras.up. pt/uploads/ficheiros/artigo8011.pdf. Acesso em: 25 abr. 2013.

OSSORIO ALVARIÑO, Antonio Àlvarez. Rango y aparencia: el decoro y la quiebra de la distinción en Castilla (ss.XVI - XVIII). Disponível em: http://rua.ua.es/dspace/bitstream/10045/4776/1/RHM_17_14.pdf. Acesso em: 6 jan. 2014.

PILLA, Maria Cecília Barreto Amorim. Manuais de civilidade, modelos de civilização.

\section{Disponível}

em: http://www.ufpel.edu.br/ich/ndh/hr/hr_09/historia_em_revista_09_maria_pilla.ht ml. Acesso em: 3 jan. 2013.

PINCIANO, Alonso López. Philosophía antigua poética. Madrid: Biblioteca Castro, 1973. Obras Completas I.

PUEO, Juan Carlos. Ridens Et Ridiculus: Vincenzo Maggi y la teoria humanista de la risa. Tropelías - Revista de Teoría de la Literatura y Literatura Comparada. Zaragoza: Litocian S.L., 2001.

QUEVEDO, Francisco de. Los Sueños. PML Ediciones, 1995.

QUINTILIANO, Marco Fabio. Instituciones Oratorias. Libro Undécimo, Cap. II. Disponível em: http://www.cervantesvirtual.com/obra-visor/institucionesoratorias--0/html. Acesso em: 20 ago. 2012.

RALLO-GRUSS, Asunción. Estudios sobre el diálogo renacentista español Antologia de la crítica. Málaga: Ed. Universidad de Málaga, 2006.

Retórica a Herênio. Trad. e intr. de Ana Paulo Celestino Faria e Adriana Seabra. São Paulo: Hedra, 2005.

RILEY, Edward. La rara invención: Estudios sobre Cervantes y su posteridad literaria. Barcelona: Crítica, 2001. 
. "La profecía de la bruja”. In: Actas del Primer Coloquio Internacional de la Asociación de Cervantistas. Anthropos, Alcalá de Henares, 29-30 nov./ 1-2 dez. 1988.

. Teoría de la novela en Cervantes. Madrid: Taurus, 1981.

. Tradición e innovación en la novelística cervantina. Disponível em: http://users.ipfw.edu/jehle/cervante/csa/artics97/riley.htm.

RICO, Francisco. La novela picaresca y el punto de vista. Barcelona: Seix Barral, 1969 (1989).

ROTTERDAM, Erasmo de. Elogio da loucura. Trad. de Maria E. Galvão. São Paulo: Martins Fontes, 2004. . Educación del príncipe cristiano. Madrid: Tecnos, 2007. A civilidade pueril. Lisboa: Editorial Estampa, 1978.

RUSSEL, Peter E. “Don Quijote y la risa a carcajadas". In: Temas de La Celestina. Barcelona: Ariel, 1978.

SALOMON, Noël. Lo villano en el teatro del Siglo de Oro. Madrid: Castalia,1985.

SAMÓSATA, Luciano de. El maestro de retórica. Trad. e notas de José Luis Navarro González. Madrid: Gredos, 1988. Obras II. . Diálogos cínicos. Madrid: Alianza, 2010. . Diálogo de los dioses, diálogo de los muertos, diálogos marinos, diálogos de las cortesanas. Madrid: Alianza, 2005.

SANCHEZ ESCRIBANO, Federico; PORQUERAS MAYO, Alberto. Preceptiva dramática española del renacimiento y el barroco. Madrid: Gredos, 1972.

SAN JUAN, Juan Huarte de. Examen de ingenios para las ciencias. Madrid: Ed. Nacional, 1976. 
SÁNCHEZ MOLLEDO , José María. Arbitristas aragoneses de los siglos XVI y XVIITextos. Zaragoza: Institución "Fernando el Católico", 2009.

SCHERE, María Jimena. El tópico del burlador burlado en los caballeros de Aristófanes. Disponível em: http://www.revistas.unam.mx/index.php/nova_tellus/article/view/36726. Acesso em: 2 jun. 2014.

SEVILLA-ARROYO, Florencio S. La literatura picaresca española. Madrid: Castalia, 2001.

SOARES, Cipriano. Arte de retórica. Coimbra: Ed. João Barreira, 1562.

SUÁREZ, Francisco. De legibus. Disponível em: http://www.cepc.gob.es/publicaciones/libros/colecciones?txtBusquedaSimple=fr ancisco\%20su\%C3\%A1rez\&rqIDC=158 pdf.

TALÉNS, Jenaro. La novela picaresca y práctica de la transgresión. Madrid: Ediciones Jucar, 1975.

TORQUEMADA, Antonio de. Colloquios satíricos: "Coloquio" de la vida pastoril. Madrid: Biblioteca Castro, 1994.

URBINA, Eduardo. El concepto de admiratio y lo grotesco en el Quijote. Disponível em: http://www.h-net.org/ cervantes/csa/artics89/urbina.htm. Acesso em: 31 ago. 2011.

SCHOLBERG, Kenneth R. Algunos aspectos de la sátira en el siglo XVI. Switzerland: Peter Lang, 1979.

VALDÉS, Afonso de. Diálogo de Mercurio y Carón. Barcelona: Planeta, 1991. Diálogo de la lengua. Barcelona: Orbis, 1983.

VILLANUEVA FERNÁNDEZ, Juan Manuel. Mira de Amescua, maestro de Calderón. Disponível em: 
http://dspace.unav.es/dspace/bitstream/10171/23080/1/20_Villanueva.pdf.

Acesso em: 11 fev. 2014.

VILLALTA, Luiz Carlos. A educação na colônia e os jesuítas: discutindo alguns mitos. Disponível em: http://www.fafich.ufmg.br/pae/apoio/aeducacaonacoloniaeosjesuitasdiscutindoal gunsmitos.pdf. Acesso em: 29 jun. 2012.

VILAR, Mario Prades. La teoría de la simulación de Pedro de Ribadeneyra y el "maquiavelismo de los antimaquiavélicos".

Disponível em: http://dx.doi.org/10.5209/rev_INGE.2011.n5.36222.pdf. Acesso em: 6 mar. 2014.

VIEIRA, Maria Augusta da C. O dito pelo não-dito. São Paulo: Edusp, 1998. Dom Quixote: A letra e os caminhos. São Paulo: Edusp, 2006. A narrativa engenhosa de Miguel de Cervantes. São Paulo: Edusp, 2012. . “La discreción como práctica de representación en 'El curioso impertinente'. In: Peregrinamente Peregrinos. Atas del $\mathrm{V}$ Congreso Internacional de la Asociación de Cervantistas. Lisboa: 2004.

. "La discreción en el episódio del Caballero del Verde Gabán". In: REICHENBERGER, Kurt (Coord.). Cervantes y su mundo. 2004.

. "Sociedad de corte, civilidad y retórica en el Quijote". In: Los Espacios de la sociabilidad en la narrativa cervantina. Costa Rica: Arlekín, 2011.

Notas sobre os prólogos de Cervantes. Disponível em: http://www.proec.ufg.br/revista_ufg/dezembro2011/arquivos_pdf/artigos_notas. pdf. Acesso em: 23 maio 2013.

VIVES, Juan Luis. Tratado del alma. Madrid: Lectura, 1923. 
Tratado de la enseñanza, Introducción a la sabiduría, Escolta del alma,

Diálogos, Pedagogía pueril. México: Editorial Porrúa, 2004, n. 447.

ZIMIC, Stanislav. El teatro de Cervantes. Madrid: Castalia, 1992.

ZINGANO, Marco. Estudos de ética antiga. 2 ed. São Paulo: Paulus/ Discurso Editorial, 2007. 